UNIVERSIDADE DE SÃO PAULO

FACULDADE DE FILOSOFIA, LETRAS E CIÊNCIAS HUMANAS

DEPARTAMENTO DE LETRAS CLÁSSICAS E VERNÁCULAS

PROGRAMA DE PÓS-GRADUAÇÃO EM FILOLOGIA E LÍNGUA PORTUGUESA

ANA ELVIRA LUCIANO GEBARA

O ensino singular dos gêneros poéticos

Reflexões e propostas 
UNIVERSIDADE DE SÃO PAULO

FACULDADE DE FILOSOFIA, LETRAS E CIÊNCIAS HUMANAS

DEPARTAMENTO DE LETRAS CLÁSSICAS E VERNÁCULAS

PROGRAMA DE PÓS-GRADUAÇÃO EM FILOLOGIA E LÍNGUA PORTUGUESA

\title{
O ensino singular dos gêneros poéticos Reflexões e propostas
}

\begin{abstract}
Ana Elvira Luciano Gebara
Tese de Doutorado apresentado ao Programa de Pós-Graduação em Filologia e Língua Portuguesa da Faculdade de Filosofia, Letras e Ciências Humanas da Universidade de São Paulo para obtenção do título de Doutor em Letras.
\end{abstract}

Orientador:

Profa. Dra. Norma Seltzer Goldstein 
Gebara, Ana Elvira Luciano

O ensino singular dos gêneros poéticos: reflexões e propostas / Ana Elvira Luciano Gebara; orientadora Norma Seltzer Goldstein. -- São Paulo, 2009. $268 \mathrm{p}$.

Tese (Doutorado - Programa de Pós-Graduação em Filologia e Língua Portuguesa do Departamento de Letras Clássicas e Vernáculas) - Faculdade de Filosofia, Letras e Ciências Humanas da Universidade de São Paulo.

1. Gêneros poéticos - Ensino - Representação. 2. Sequências didáticas. I. Título. II. Goldstein, Norma Seltzer 


\section{AGRADECIMENTOS}

Ao Centro de Estudos e Pesquisas em Educação, Cultura e Ação comunitária, CENPEC,

aqui representados na pessoa de sua presidente Maria Alice Setúbal e da coordenadora do projeto Escrevendo o futuro (em 2004),

hoje Olimpíada de Língua Portuguesa, Sonia Madi

À banca de qualificação,

pela leitura cuidadosa e esclarecedora

Ao meu grupo de pesquisa,

cujas leituras, trabalhos e ouvidos foram muito úteis e reconfortantes.

Aos meus interlocutores essenciais,

Viviane, Garcez, Jiro, Alzira e Jaqueline 


\section{DEDICATÓRIA}

A Fernando, Daniel, Helena e Marina, eis-me de volta.

Ao meu pai que me ensinou que o mundo está no papel.

A minha mãe que me ensinou a dizer os poemas em voz alta.

À Norma

que me fez acreditar que é possível 


\title{
RESUMO
}

Em virtude de representações por vezes pouco favoráveis dos gêneros poéticos no ambiente escolar, os enunciados pertencentes a esses gêneros são marginalizados em sala de aula, ocupando um espaço exíguo nas atividades de leitura e mais reduzido ainda nas atividades de escrita. Mesmo que essa seja a realidade dominante na escola, propostas para o ensino dos gêneros poéticos têm despertado interesse dos alunos quando apresentados de forma a não singularizar o estudo do poema. Assim, buscando compreender como ocorrem e qual a estrutura das episódicas propostas com o texto poético, neste trabalho, analiso o material que envolve o Prêmio "Escrevendo o Futuro" - da apresentação da proposta aos professores até a etapa de escolha dos finalistas (capítulo 1). Embora o Prêmio tenha alcançado o território nacional, o corpus analisado no capítulo 2 está circunscrito ao Pólo São Paulo, composto por nove poemas de várias cidades do Estado de São Paulo. O material analisado se estrutura em sequências didáticas, segundo as concepções de trabalho com os gêneros de Schneuwly e Dolz (2004), suporte teórico de minha pesquisa ao lado de Bakhtin (1976; 2003); Jolibert (1994, 1994a, 2008) e Bazerman (2005; 2006 e 2007). O objetivo do trabalho é 1) indicar quais as representações presentes no espaço escolar; 2) verificar como o ensino dos gêneros poéticos se apresenta nessa proposta; 3) apresentar, por meio da reflexão teórica, representações plurais dos gêneros poéticos que possam indicar caminhos possíveis de serem aplicados como no caso do Prêmio em diferentes contextos, implicando novos lugares para o professor e para os alunos, em novos papéis.

PALAVRAS-CHAVE: Ensino dos gêneros poéticos; Sequências didáticas; Representação dos gêneros poéticos

\section{TITLE: THE SINGULAR TEACHING OF POETIC GENRE: REFLECTIONS AND PROPOSALS}

\begin{abstract}
Unflattering representations of the poetic genre among primary and secondary school teachers often translate into a secondary place for poetry in the classroom. Seldom an object for reading activities, it is even more rarely used as a source for those of writing. In spite of that, students respond enthusiastically to the odd projects and activities which do offer to go beyond the study of individual poems. This dissertation focuses on one such project: the "Escrevendo o Futuro" Award, examining it from its presentation to teachers to the selection of candidates for the final round (chapter 1). Although the EF Award is a national competition, all the nine poems which constitute the corpus analyzed in chapter 2 come from the State of São Paulo. The material analyzed is structured in didactic sequences. The theoretical framework for such analysis draws on the works of Schneuwly e Dolz (2004), Bakhtin (1976; 2003); Jolibert (1994, 1994a, 2008) and Bazerman (2005; 2006 e 2007). The goals of this dissertation are: 1) identifying various representations of the poetic in primary and secondary schools; 2) examining the place poetry has in this context; 3) offering, based on a critique of the scholarly research on the field, alternative, plural possibilities of representation of the poetic genres which may lead to new roles for teachers and students visà-vis their working with poetry in the classroom.
\end{abstract}

Key-words: Teaching of the poetic genre; didactic sequences; representations of poetic genres; proposal for the teaching of poetic genres. 
Banca Examinadora 


\section{Sumário}

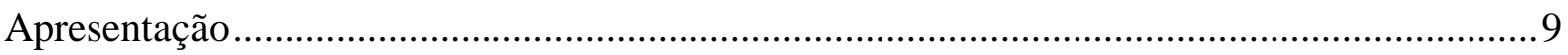

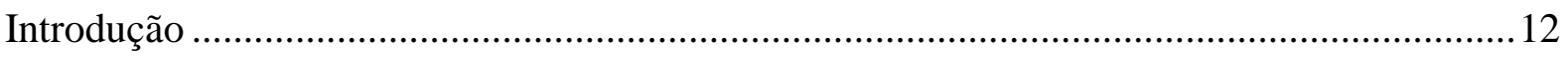

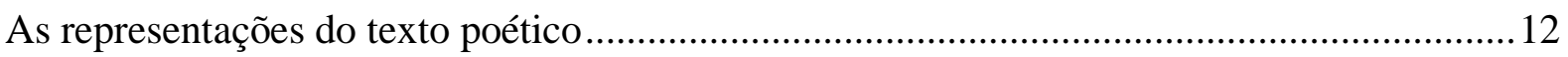

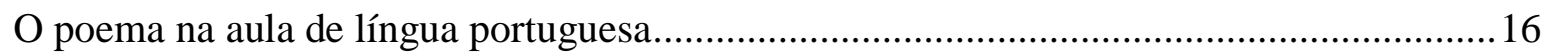

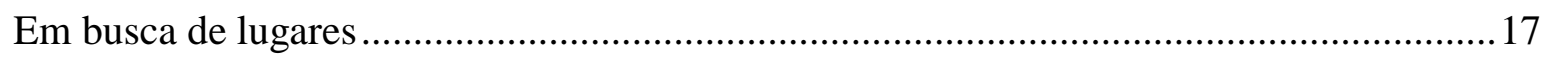

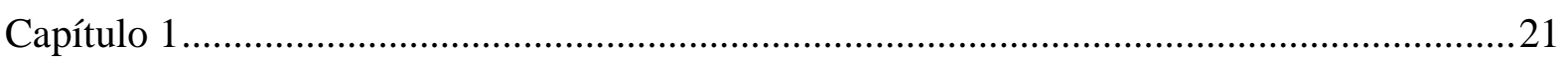

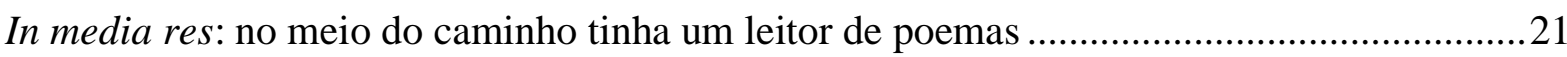

1.1 Qual o espaço para o leitor de poemas na sala de aula?...........................................23

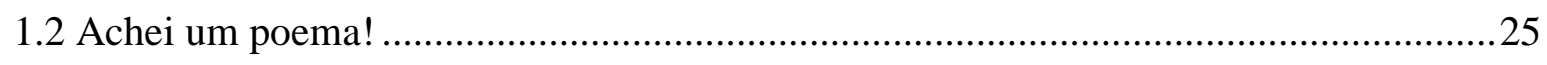

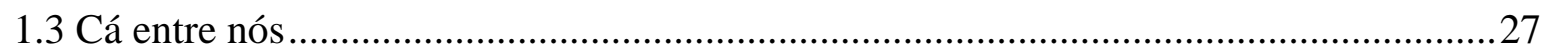

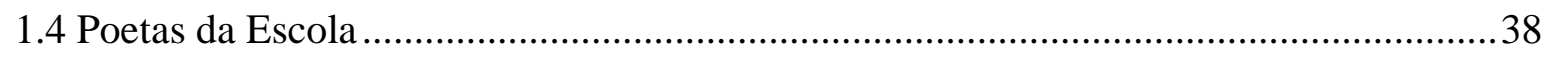

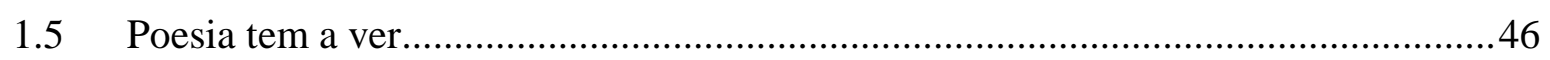

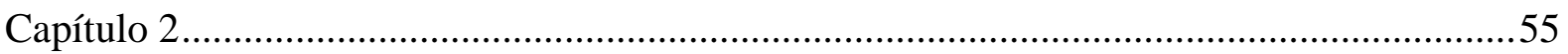

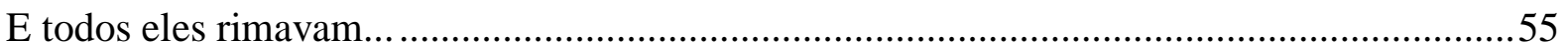

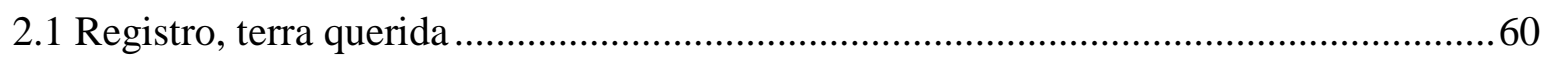

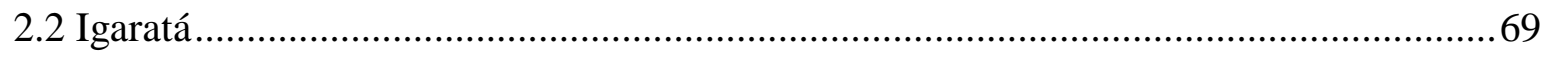

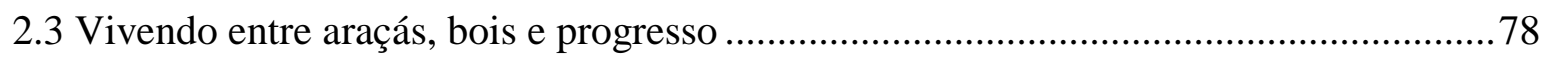

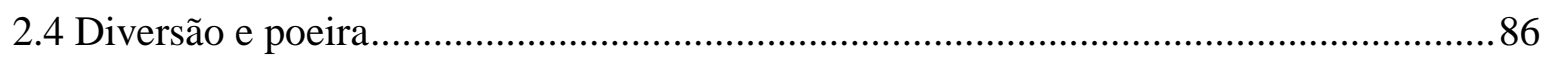

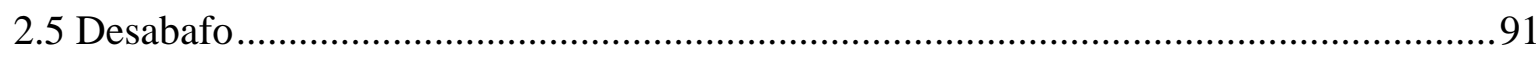

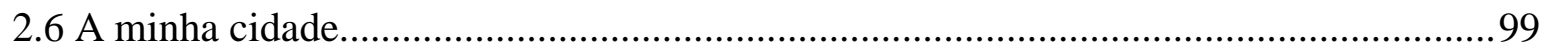




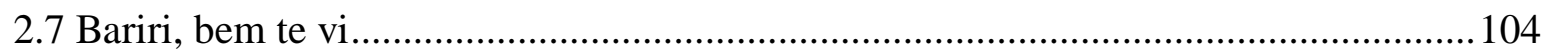

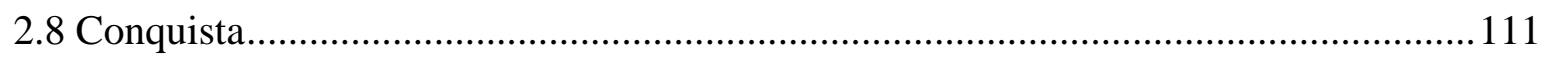

2.9 Minha pátria, minha língua: sonho possível? ........................................................ 116

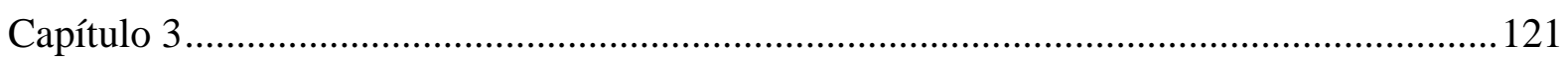

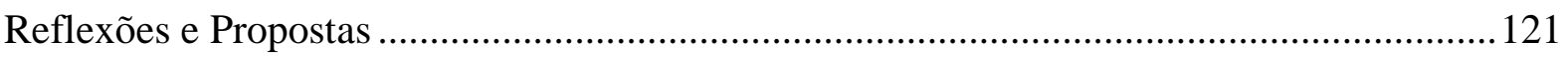

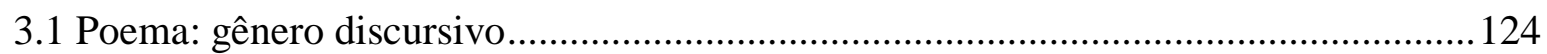

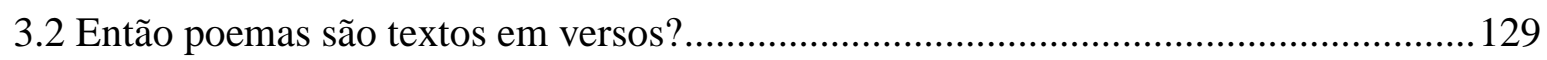

3.3 Então é possível aprender a ler e escrever poemas na escola? ..................................133

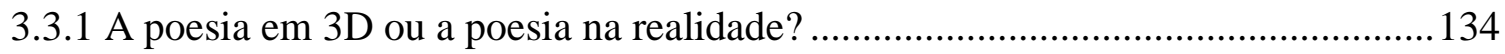

3.3.2 Representações dos gêneros poéticos, indo além dos versos ................................138

3.4 O poema: uma esfinge? O poema diante dos olhos dos alunos .................................154

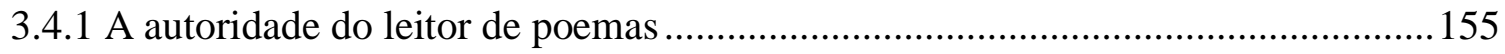

3.5 Sabe o nome do poeta? Propostas para a escritura do poema ...................................157

3.5.1 Uma proposta, muitas propostas, nenhuma delas .......................................... 159

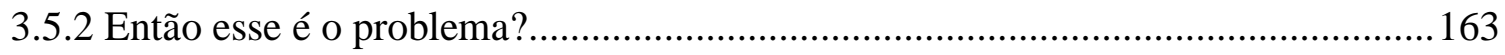

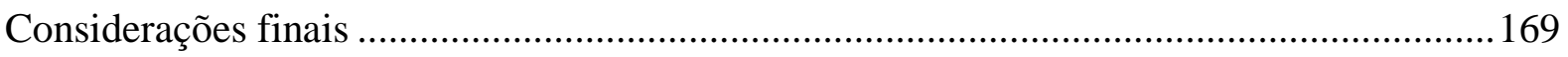

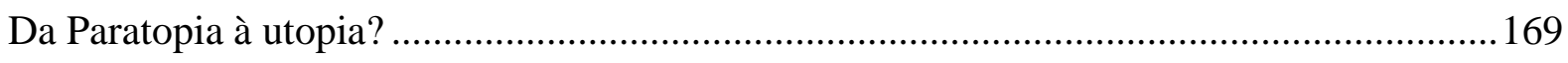

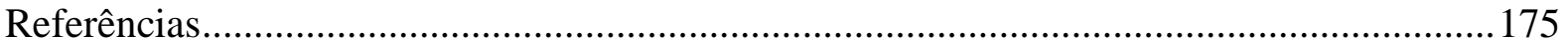

ANEXO 1 - Fascículo Poetas da Escola (reprodução xerográfica) ...................................... 184

ANEXO 2 - Relatos dos professores (reprodução xerográfica) .........................................249

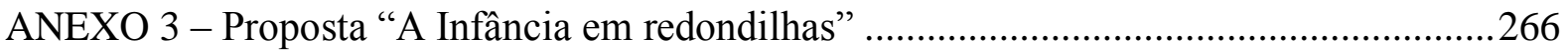




\section{Apresentação}

Quando era bem pequena, muitas vezes, ouvi minha mãe declamando (como se chamava na época e como se fazia muito) "Meus oito anos", de Casemiro de Abreu. Depois do encontro com o poema, olhava os versos no livro dela, Leituras da $4^{a}$ série, desejando sabê-los de cor. Não importava "o peito aberto", nem "as laranjeiras e as bananeiras", o que me movia eram as palavras no arranjo harmonioso que permitia à voz dela preencher o meu corpo transformando-se instantaneamente em memória. Poucos anos depois no antigo primário, foi a vez de uma professora substituta brincar com as palavras num poema sobre os bandeirantes. Desse segundo poema, só me lembro das imagens que ainda formigam minha memória, pois a entonação, o crescendo e decrescendo da voz dela, a força que ela nos pedia para imprimir aos versos ficaram colados à idéia de como se aproximar do poema. E eu as levei comigo, as vozes e os modos de ler. Essas impressões foram tão fortes que outras experiências não apagaram a presença da idéia de poema que se havia escrito em mim. Talvez por causa dessa exposição precoce e consistente, desde então, poemas têm ocupado um espaço central na minha vida... Agora, passando esses fatos no crivo da minha perspectiva de pesquisadora, encontro nessas experiências e na busca de repetição desses prazeres, que hoje não são tão simples e imediatos como antes, a base de minha pesquisa. ${ }^{1}$

No fim do $1^{\circ}$ semestre de 2005, quando prestei a prova para o ingresso no Doutorado, tinha um pré-projeto cujo tema era o ensino do gênero poético. Na entrevista, após a leitura da prova, fui questionada sobre a possibilidade de o poema ser considerado como gênero discursivo e desde então essa tem sido uma das minhas buscas. O poema é um gênero discursivo? A adoção dessa perspectiva teórica auxiliaria o ensino desse gênero?

O poema sempre foi uma preocupação nos meus estudos muito antes da graduação. $\mathrm{Na}$ época em que cursava o magistério, isso ocorria porque sempre que, no meu grupo de trabalho e de estudos, estabelecíamos uma estratégia para apresentar os poemas para nossas colegas "normalistas" ou para os alunos nos estágios, o resultado era de tal forma positivo que nos perguntávamos por que o poema não circulava mais.

\footnotetext{
${ }^{1} \mathrm{O}$ uso da primeira pessoa do singular se estende além das páginas de apresentação alternando-se com a terceira do singular ou a primeira do plural, porque acredito que essa forma tenha mais aderência aos processos que descrevo pelo envolvimento e pelo tipo de reflexão desenvolvido.
} 
Meu grupo da época do magistério seguiu caminhos diversos e eu fiquei com essa questão. Sempre que podia lia poemas para as crianças e conversávamos sem mais compromissos. Porém, isso não era suficiente. Assim, na graduação, em Letras, na FFLCH da USP, tentei entender como poderia trabalhar com esse gênero de forma que as atividades fossem prazerosas, produtivas, conduzindo a uma autonomia do aluno como leitor e produtor, que acreditava e acredito serem efeitos da leitura de poemas. Então, descobri a Estilística e seu instrumental que proporcionaram uma forma de desbastar o mato daninho que havia na trilha que tentava empreender. Embora a trilha ainda apresentasse muitos obstáculos, comecei a estudar o poeta Manuel Bandeira no grupo de Iniciação Científica, orientada pela Profa. Dra. Norma Seltzer Goldstein. A poesia começava a ganhar o status de estudo teórico de que eu necessitava para responder àquelas questões há tanto formuladas. Esse trabalho resultou na publicação, pela Editora Humanitas- FFLCH USP do livro Traços marcantes no percurso poético de Manuel Bandeira (GOLDSTEIN, 2005).

Após a graduação, participei do grupo de pesquisa interdisciplinar, interdepartamental e inter-institucional "Aprender e ensinar com textos" cujo histórico e cujos resultados estão na coleção de mesmo nome publicada pela Cortez Editora. O grupo do qual fiz parte foi responsável por dois volumes dessa coleção, Aprender e ensinar com textos didáticos e paradidáticos (volume 2 da coleção Aprender e Ensinar com textos, de 1997) e Leitura e construção do real: o lugar da poesia e da ficção (volume 4 da mesma coleção, de 2000), ambos coordenados pela Profa. Dra. Guaraciaba Micheletti. Nessa pesquisa, tive a oportunidade de discutir como ocorria a circulação do poema em sala de aula, sua presença no livro didático (discussão presente no ensaio "O poema, um texto marginalizado", no volume 2, 1997) e possíveis caminhos para uma maior circulação efetiva (reflexões desenvolvidas em co-autoria nos ensaios "Construção, desconstrução e reconstrução na busca de significados no / do poema", com Guaraciaba Micheletti e Letícia Paula de Freitas Peres, e "Etiqueta, homogeneização, reificação", em co-autoria com Guaraciaba Micheletti, no volume 4, 2000)

Naquela época, fui apresentada pela coordenadora do meu grupo, Profa. Dra. Guaraciaba Micheletti, ao poeta que marcou meus trabalhos durante o mestrado, tornando-se o tema da dissertação "Os convites da poesia - a obra poética de José Paulo Paes para crianças".

No mestrado, sob a orientação da Profa. Dra. Norma Seltzer Goldstein, ao identificar a busca de Paes por uma formação de leitores de poesia, tentei, ao analisar sua obra, 
explicitar como ocorria a leitura de poemas, unindo-me ao poeta na proposta da leitura como brincadeira e do poema como brinquedo. Essa visão lúdica de leitura guia até hoje os meus estudos, sendo ratificada por vários autores, que desenvolvem essa idéia de diferentes formas na busca de uma "escola da poesia" como propõe Georges Jean (1995).

Após o ingresso no doutorado, cursei a disciplina "Faces da poesia brasileira a partir dos anos 60", ministrada pela Profa. Dra. Viviana Bosi, do Departamento de Teoria Literária e Literatura Comparada da FFLCH-USP. O meu objetivo nessa disciplina era fazer a ponte entre os estudos literários e os estudos linguístico-discursivos sobre o poema, que eu vinha desenvolvendo há certo tempo. Considero-me uma professora de Língua Portuguesa e a literatura sempre foi um desafio. Trazer o texto literário para a sala de aula significava assumir um compromisso com outras áreas do saber com as quais eu precisava lidar de maneira mais programática, além das práticas que desenvolvi graças aos estudos linguísticos da Língua Portuguesa desde a graduação, em várias perspectivas teóricas. Percebi, nesse momento, que esse era um dos pontos significativos para a formação do professor de Língua Portuguesa, no ensino fundamental, ampliar sua área de atuação, instrumentalizando-o.

Resta, aqui, antes de começar a leitura do trabalho, a pergunta: será possível levar o poema para a escola? Levaria anos, como disse Leminsky nos versos da epígrafe? A resposta, diante do percurso exposto e ainda em andamento, é: sim, pois os poéticos são gêneros de resistência, de formação humanista como os demais gêneros da esfera do literário, que podem promover a formação do professor e do aluno. Além disso, busco uma resposta para a questão que ouvi, em um minicurso, de uma professora do Ensino Médio: "Como convencer os pais de que poema é importante, se eles só querem ver os filhos treinando a famosa redação do vestibular?" Este trabalho também ambiciona, como efeito colateral, explicitar alguns argumentos para responder a essa pergunta, parte na análise do corpus e parte na formulação de uma proposta possível. 
Introdução

As representações do texto poético 
Como ocorre em todas as áreas de conhecimento, como ocorre na vida, a nomeação implica mudanças em conceitos e mudanças no objeto. Isso ocorreu com os gêneros poéticos. Durante muito tempo, e ainda hoje, a concepção dos gêneros poéticos esteve ligada às concepções da teoria literária. Esse enfoque resultava em uma conceituação de gênero poético baseada na assunção de um modo de compor forma e tema e de se encaixar na tradição literária, ora como continuação dessa tradição ora como transgressão.

\footnotetext{
Não há grandes problemas, na maioria dos casos, em atribuir as obras literárias individuais a um destes gêneros. Pertencerá à Lírica todo poema de extensão menor, na medida em que nele não se cristalizarem personagens nítidos e em que, ao contrário, uma voz central - quase sempre um "Eu" - nele exprimir seu próprio estado de alma. Fará parte da épica toda obra - poema ou não - de extensão maior, em que um narrador apresentar personagens envolvidos em situações e eventos, Pertencerá à Dramática toda obra dialogada em que atuarem os próprios personagens sem serem, em geral, apresentados por um narrador. (ROSENFELD, 1965, p. 5)
}

Rosenfeld assinala que essa concepção "substantiva" não apresenta maiores obstáculos no momento da classificação, porém há, na concepção tripartida dos gêneros, um caráter "adjetivo" que exige constante reavaliação, ou pelo menos uma abertura para intersecções. Nesse caso, a classificação se volta para a predominância e as primeiras dissensões podem ser sentidas, pois esses gêneros passam a se deslocar no espaço da taxonomia.

Embora possam permanecer em sistemas classificatórios desenvolvidos ao longo dos séculos, sem perdas, a infindável atualização que os escritores fazem dessas formas de organização e atuação social parece demandar uma adequação constante. (D’ONOFRIO, 2007) Principalmente, se se referir ao ambiente escolar, em que a tradição (bem ou mal absorvida, assunto a que voltarei mais adiante) dita ainda a forma de se compreender os fenômenos e objetos à volta do estudante.

Estudar os gêneros poéticos e se apresentar como leitor desses gêneros pressupõe, nesse contexto, posicionar-se como um leitor com conhecimento das formas poéticas ou das concepções estéticas que caracterizavam a tradição vigente ou do entorno ao poema num preciso momento histórico. O posicionamento pode ser bem sucedido ou não e decorre, muitas vezes, das representações que se tem dos gêneros em questão. A força dessas 
representações é resultante de sua natureza convencional e prescritiva. Como postula Moscovici, as representações sociais

convencionalizam os objetos, pessoas ou acontecimentos que encontram. Elas the dão uma forma definitiva, as localizam em uma determinada categoria e gradualmente as colocam como um modelo de determinado tipo, distinto e partilhado por um grupo de pessoas. Todos os novos elementos se juntam a esse modelo e se sintetizam nele. (MOSCOVICI, 2007, p. 34)

Surge então a necessidade de mapear as representações fundada no fato de que, muitas vezes, a comunidade externa à escola legitima ou tem legitimado posturas que nem sempre são compreendidas de forma a serem operacionalizadas pelo ambiente escolar. Talvez porque a operacionalização, esse fazer escolar, seja o grande problema. Desde sempre a leitura de poemas despertou nos teóricos uma gama de procedimentos ou a própria negação dos fazeres da leitura. As contraditórias (o adjetivo sendo entendido como posições em confronto) concepções de leitura do gênero lírico aparecem em Staiger dessa maneira:

\begin{abstract}
A interpretação separa em partes distintas o que em sua origem é enigmaticamente uma só coisa. Além disso, ela não pode nunca desvendar todo o mistério da obra lírica. Pois esse estado de unicidade (Einssein) é mais íntimo que a mais sagaz perspicácia de espírito; capaz de notar como uma face "fala" muito mais que qualquer descrição fisionômica e a alma é mais profunda que qualquer tentativa de interpretação psicológica. (STAIGER, 1975, p. 21)
\end{abstract}

Seguindo essa descrição valorativa da leitura associada ao processo de interpretação, observa-se que a sala de aula e os exercícios não permitiriam a compreensão do poema. Em nada auxiliariam o aluno. Esses tipos de atividade estariam negando o lírico, podendo ser lido em sala somente o épico, porque também o dramático não alcançaria a totalidade de propósitos em uma leitura em voz alta. Como grande parte dos poemas, que circulam em sala de aula, pode ainda ser classificada como pertencente à lírica, instaura-se uma primeira e problemática situação que validaria apenas o uso de poemas de temas circunstanciais no ambiente escolar, pois estes se prestariam à declamação e ao exame retórico, organização textual que supostamente não apareceria nos líricos (STAIGER, 1975, p.83). Além disso, essa concepção de poema exilaria o gênero lírico para as leituras individuais, ou as "pequenas reuniões" como afirma Staiger (1975, p.49), ratificando uma representação do poema como impossibilidade para certos espaços ou para relações de caráter coletivo.

O crítico associa o lírico à vida solitária, pois o poeta lírico "não se interessa pelo público; cria para si mesmo.” (STAIGER, 1975, p. 48). Para ele, a relação poeta - poema leitor só poderia acontecer na leitura autêntica. 
A uma leitura autêntica, o próprio leitor vibra conjuntamente sem saber por que, ou melhor, sem qualquer razão lógica. Somente quem não vibra em uníssono com a obra exige razões. Somente quem não consegue participar diretamente do clima lírico, terá que o considerar possível e dependerá de uma compreensão. (STAIGER, 1975, p. 48)

Parece-nos, então, que os professores, alheios à idéia do que seja o poema lírico pelo menos enquanto ocupam a função docente, criariam obstáculos e não, caminhos para seus alunos. Seria possível, nessa concepção, levar o poema para a sala de aula?

A representação do poema como impossibilidade ou como um objeto a ser fruído por poucos parece estar vigendo até hoje. Ela se desenvolveu ao lado de outras representações que recuperam no gênero lírico acima de tudo, mas também no literário, em geral, a idéia de que esses gêneros pertencem a esferas em que o leitor comum não consegue circular (PINHEIRO, 2006). Em vez de existir uma interação, há uma justaposição, sem que se processe a ação em si. São representações de poema como textos criptografados. Essa, porém, não era a concepção de Staiger que tampouco estava interessado no ensino. Suas idéias refletiam concepções filosóficas da linguagem e seus modos de organização. A transposição de conceitos de áreas diversas para o ensino dos gêneros literários pode ser responsável pelo alheamento dos leitores, uma vez que os estudos eram formas de questionar a natureza dos espaços, deixando fora de seus objetivos o mapeamento da superfície desses espaços para compreendê-los.

Mesmo assim, críticos e teóricos como Staiger, parecem bastante pertinentes, ao afirmar, como nesse caso, que a leitura autêntica leva a uma espécie de vibração individual. Poderia ser o sentimento de síntese, a empatia e outras formas afins de relacionamento com o texto poético. Se pensássemos dessa forma, retiraríamos das mãos do professor, aquele trabalho compulsório que nada acrescenta ao aluno a não ser folhas preenchidas no caderno e no livro didático. O poema estaria livre para circular por espaços mais significativos, saindo das lições de casa e dos exercícios em que não seria possível esse tipo de relação. Porém, imediatamente a essa solução, surge um problema, ou uma questão (diriam os menos extremados): o poema que aparece na escola precisa de uma autenticação dessa instituição, de seus procedimentos analíticos e da reconstituição de sentidos que hoje são necessários para o ensino de língua materna, pois, na maioria das vezes, somente durante os minutos que compõem a aula esses gêneros circulam. 


\section{o poema na aula de língua portuguesa}

A tarefa do professor de língua materna, hoje em dia mais do que nunca, assumiu novos contornos. Proceder a uma "necropsia" do texto, como seria possível descrever o procedimento das análises de natureza estrutural apenas, não está entre as atribuições desse profissional. É necessário o estabelecimento de outras abordagens como as dos gêneros para que as atuais sejam revistas e para que o trabalho em sala de aula se torne novamente significativo. Não se trata da negação das concepções existentes; o que se busca são aproximações por caminhos diversos que possam romper com posturas que impedem, algumas vezes, o professor de língua de trabalhar com os gêneros literários e, mais especificamente, com o poético, por uma suposta incapacidade de seu instrumental ou de sua área de ação. Caberia, nessa divisão

quase fordiana de tarefas, ao professor de Literatura, o trabalho com os gêneros literários, cabendo àquele o exame estrutural dos textos. Essa divisão bloquearia a construção dos sentidos e a leitura que levasse à síntese interpretativa.

Serrani, ao retomar as interrogações que situaram o projeto desenvolvido sob sua orientação, envolvendo literatura e ensino de língua - “(1) a relação dos estudantes com as obras; (2) o tratamento integrado de língua e literatura; (3) os efeitos da utilização de materiais com convivência de linguagens (poesia e música)" (SERRANI, 2005, p. 52)-, relata que "aspectos que pareciam típicos dos estudos de textos literários são observados em textos não literários e a oposição binária língua-literatura perde o sentido nas aulas, ao considerar-se a produção e circulação de discursos.” (SERRANI, 2005, p.58)

Como fazer esse percurso de integração? Como promover esse fazer em relação aos poemas que nos rodeiam? A hipótese desta pesquisa se baseia no estudo de percursos já vivenciados em propostas que tenham os gêneros discursivos como abordagem para o trabalho e como perspectiva teórica, pois como afirma Rojo, se para o linguista é indiferente a escolha entre as diferentes teorias, porque essa escolha depende da finalidade da pesquisa e de suas posturas ideológicas; para o linguista aplicado, a "validade de pesquisa irá depender mais da eficácia social que da precisão da análise." (ROJO, 2005, p. 206) Assim, quando se trata do trabalho com o texto, via gênero, a pesquisadora identifica:

Nossas experiências, tanto na formação de professores como na análise de interações em sala de aula, orientaram-nos na direção de um enfoque bakhtiniano. 
Nossos professores de língua - seja por formação profissional, seja por falta de formação - são muito atraídos pela descrição de língua e pelo ensino de gramática. Sempre fazemos sucesso na formação de professores quando discutimos as características formais e de estilo de um texto ou gênero, a partir de nossos instrumentos. Por outro lado, nossos alunos não precisam ser gramáticos de texto e nem mesmo conhecer uma metalinguagem sofisticada. Ao contrário no Brasil, com seus acentuados problemas de iletrismo, a necessidade dos alunos é de terem acesso letrado a textos (de opinião, literários, científicos, jornalísticos, informativos etc.) e de poderem fazer uma leitura crítica e cidadã desses textos.

Assim, parece-nos ser mais útil e necessário explorar com eles as características das situações de enunciação - relacionadas às marcas linguísticas que deixam como traços nos textos - que fazermos análises completas e exaustivas dos textos, introduzindo uma nova metalinguagem. (ROJO, 2005, p. 207)

Alinhada a essa opção, optou-se, como foco da análise, pelo exame de uma proposta já aplicada, de alcance nacional, para verificar como se dá o ensino do gênero poético e quais as características dessas propostas que o fazem (ou não) possível.

\section{Em busca de lugares}

Horácio pode nos emocionar até hoje ${ }^{2}$. Mas há alguns de seus poemas que precisam da reconstrução de um percurso para que a leitura se efetive. Há dados que vinculam o texto e o homem a visões de mundo que não são mais as nossas. A "vibração" neste caso ${ }^{3}$ requer o auxílio dessa compreensão de tempo, espaço e outros discursos distantes. O mesmo poderia ser dito a respeito de Camões, dos barrocos, dos românticos, poetas que se afastam aos poucos de nossas concepções estéticas e de mundo, e de nossos instrumentais para a atribuição de sentido. Muitas vezes, não reconhecer a transgressão de uma poética, ou seja, de uma concepção estética, pode levar a um equívoco, a interpretações inadequadas. Seria o caso de ficarmos alheios a esses textos?

As concepções de aulas de língua materna, segundo os documentos sobre a educação em vários países (como Portugal e Brasil, neste caso, os PCN), demonstram que não. Elas têm como meta responder a essa demanda (a reconstrução de percursos), ao trabalhar com a língua como interação, a ação que se desdobra em direção ao outro, onde e quando ele estiver. Nessas aulas, todos os textos podem conviver e promover a descoberta de lugares no

\footnotetext{
${ }^{2}$ A escolha do poeta teve como critérios a distância e a influência na lírica até os nossos dias.

3 Retomando "vibração" tanto como leitura individual de Staiger quanto como leitura crítica e cidadã indicada por Rojo, cf respectivamente p. 10 e 12.
} 
mundo para esses alunos. Assim mescla-se a história dos significados construída em momentos diversos do sistema linguístico à indispensável trajetória da língua como representação do homem, individual ou coletivamente, em posições sociais, ideológicas e psicológicas, permitindo que pouco se apague com o passar dos dias.

Em busca de novos papéis e da agência ${ }^{4}$ para os professores de língua materna, que envolvam desde o conhecimento específico ${ }^{5}$ até o conhecimento discursivo do mundo, propostas foram se apresentando, entre elas a do ensino de língua materna com os gêneros discursivos, conceito pertencente às formulações de Bakhtin (2003), linha a que me filio, utilizando para a análise da proposta que constitui parte do corpus, a re-leitura do conceito bakhtiniano de gênero transposto para a esfera escolar de Schneuwly e Dolz (2004), e para a análise dos poemas dos alunos, além desses conceitos, as questões de representação de Moscovici (2007) e de ethos de Maingueneau (2006, 2008). Para a formulação de uma proposta de ensino do gênero poético, amplio a base teórica utilizando Bazerman (2006; 2007) ao lado de outros trabalhos de Bakhtin (1976; 1993), das propostas para a organização dos gêneros de Batista (2001) e das discussões sobre a concepção bakhtiniana de prosa e poesia em Tezza (2003), ao lado da estruturação da leitura do tipo textual, poema, de Adam (1985) e de Jolibert (1994, vol. I e II).

A linha de onde esta pesquisa parte, portanto, é o estudo do ensino de língua materna com os gêneros e pelos gêneros. Dentro dessa linha, a análise de uma proposta de ensino do poema como gênero, se configurou como o corpus da pesquisa, levando em consideração as representações de leitor e de produtor do gênero poético. A proposta escolhida foi implementada na forma do Prêmio "Escrevendo o Futuro", um projeto do Centro de Estudos e Pesquisas em Educação, Cultura e Ação Comunitária (CENPEC) em convênio com o Instituto Itaú, cujo tema em 2004, edição da qual foi feita a recolha do corpus analisado, era “o lugar onde vivo". Esse projeto envolveu, durante alguns anos ${ }^{6}$, o ensino dos gêneros na escola, naquela etapa, limitados a três: texto de opinião, memórias e poesia.

A questão da representação do leitor e produtor surgiu como um dos componentes a ser analisado, porque para se colocarem na posição de produtores, os alunos projetam, na escrita, as concepções de poema provenientes de suas leituras. Relevante para a questão,

\footnotetext{
${ }^{4}$ Agência entendida como a ação do sujeito e sua forma de se relacionar nos diversos campos e esferas utilizando os gêneros (BAZERMAN, 2006).

${ }^{5}$ Conhecimento específico como o conhecimento referente ao gênero em sua estrutura composicional.

${ }^{6}$ Hoje o projeto ainda se desenvolve tendo agora a forma de Olimpíada de Língua Portuguesa, cf. http://olimpiadadelinguaportuguesa.mec.gov.br/olimpiada
} 
portanto, é posicionar-se para a legibilidade desse gênero, sendo implicada, nesse processo, a busca por posições axiológicas que envolvem conhecimento de mundo e da cultura, acrescidas de conhecimento estrutural da língua e de seu funcionamento, numa percepção que se estende a domínios além do uso comum da linguagem. Paradoxalmente, trata-se de uma posição envolvendo uma combinação de extrema especialização com processos semelhantes aos de aquisição de linguagem, pois necessita da desmecanização da percepção da linguagem, o que permitiria estar fora da linguagem para manipulá-la. Essa junção teria sido possível para os alunos envolvidos no Prêmio?

Para responder a essa questão, a sequência dos capítulos se configura de modo que possa parecer invertida para o que se configura como gênero tese, uma vez que, nos capítulos 1 e 2, apresentam-se, respectivamente, a análise da proposta do ensino do gênero poético e a das produções de alunos semi-finalistas do Pólo São Paulo, da edição de 2004 do Prêmio "Escrevendo o Futuro", cujo desdobramento se configura no capítulo 3 por meio de uma reflexão sobre a concepção do gênero poético como gênero. Considerando ainda o conceito de agência nesse capítulo, o estudo do gênero poético converge para o papel da leitura no estabelecimento da "ensinabilidade" do gênero, em propostas para o ensino.

O capítulo 1 tem como base a concepção de gênero discursivo tal como formulada em Schneuwly e Dolz (2004), e no caso do poético, as propostas e reflexões de Jolibert (1994). Para esses teóricos, o gênero desenvolvido no ambiente escolar é redesenhado nas transposições didáticas e na abordagem particular de se aproximar de cada um dos objetos específicos, em movimentos espiralados. A concepção discursiva do gênero, para eles, tem como ponto de convergência as idéias propostas por Bakhtin, lido na tradição francesa dos estudos linguageiros. Conceitos como sequência didática, ateliês, momentos e instrumental para trabalhar com os gêneros, estão na base da proposta analisada, como ilustram as publicações voltadas para as oficinas, aplicadas pelos professores junto aos alunos das escolas que participaram do projeto (anexo 1, Cá entre nós, e o anexo 2, Fascículo Poetas da Escola).

No capítulo 2, para analisar os poemas, utilizaram-se, além dos critérios de avaliação dados pelo projeto em questão aliados aos parâmetros de trabalho com o gênero dados por Jolibert (1994, 2008), Schneuwly e Dolz (2004), os estudos estilísticos, tendo a estilística da enunciação no centro (DISCINI, 2008 e MARTINS, 1989), como elemento consoante com as concepções discursivas que permitem recuperar, no texto, processos de construção da autoria 
e da representação (MOSCOVICI, 2007) do gênero poético, especificamente focalizada na proposta, como afirma Discini: “A vinculação entre as noções de estilo e ethos permite que se examine determinado sistema de coerções semânticas que fundam o corpo do sujeito da enunciação, pressuposto a uma totalidade de enunciados.” (2008, p. 34)

No capítulo 3, recuperam-se as representações do gênero poético para uma reflexão sobre sua natureza no universo do discursivo, identificando quais deslocamentos são feitos de concepções anteriores, recuperando-as na oscilação de uma nomeação nova, que revitaliza os conceitos, ao mesmo tempo em que parte de uma tradição constitutiva. A base teórica para esse capítulo é ampliada pelos teóricos que concebem o gênero como discursivo (BAKHTIN 209, 2003; BAKHTIN, VOLOSHINOV, 1926/1976; TEZZA, 2003), em um diálogo com outros teóricos que abordaram o poema segundo outras concepções formadoras e presentes no discurso dos leitores, como BAZERMAN (2006) e ADAM (1985). Há, nesse caso, uma convergência para a questão da formação do leitor do gênero poético como um modo de ensinar o poema. O capítulo trata, também, de formas de validar as concepções discursivas envolvidas no gênero poético para então serem apresentadas as propostas, em decorrência da discussão desenvolvida nos capítulos anteriores. 
Capítulo 1

In media res: no meio do caminho tinha um leitor de poemas 


\section{Fino sangue}

Gosto de poema

que fala de ovo frito

latido de cão

e cheiro de queimado.

Poema que com pequenos cortes

vara as coisas pequenas

fura a casca

o odre

rasga a placenta

e deixa gotejar

o fino

sangue

(COLASANTI, 2005, p. 21) 


\subsection{Qual o espaço para o leitor de poemas na sala de aula?}

Começar o capítulo com uma pergunta e colocar no início da pesquisa, a análise, resultam de meu percurso de pesquisadora cujo foco sempre foi o poema e o ensino desse gênero, com ênfase na formação do leitor, como José Paulo Paes tematizou em sua obra. A formação do minileitor era algo programático em sua poética, indicando como poderia ser danosa a experiência com o poema como texto marginalizado (PAES, 1995; 1996).

A primeira razão para essa escolha se centra no fato de que a circulação do poema em espaços externos ao ambiente escolar, apesar de toda a aparente recusa (ou marginalização) do poema na sociedade capitalista, com forte apelo pragmático, apresenta uma resistência bem-sucedida, afinal o poema agora circula na internet e até nos celulares ${ }^{7}$, em projetos ligados a grupos de poetas, leitores e interessados, e também em iniciativas pessoais como blogs que encontram apoio para essa circulação no grande número de acessos. Assim o poema alcançou, antes de outros gêneros da esfera literária, suportes atuais e de prestígio em nossa época. Em contrapartida - fixando-se, então, a segunda razão -, na escola, o poema parece entrar pela porta lateral e ocupar espaços muito reduzidos. (FREITAS, 2008; PINHEIRO, 2000; GEBARA, 2002). E como todos os gêneros que circulam nesse ambiente, o poema sofre um deslocamento e uma transformação significativa, como observam Schneuwly e Dolz:

Pelo fato de que o gênero funciona num outro lugar social, diferente daquele em que foi originado, ele sofre, forçosamente, uma transformação. Ele não tem mais o mesmo sentido; ele é, principalmente, sempre - nós acabamos de dizê-lo - gênero a aprender, embora permaneça gênero para comunicar. (2004, p. 81)

Esse "desdobramento", como descrevem os autores, assume características particulares, tratados em vários trabalhos de pesquisa, como as que se referem à presença de poemas em livros didáticos. Nesses casos (LAJOLO, 1982; MICHELETTI, 2000;

\footnotetext{
${ }^{7}$ A respeito desse tipo de circulação, como o projeto Celuler, conferir "Poesia vira hit na troca de mensagens de celular", in $O$ Estado de São Paulo. Caderno Link. 01-12-2004. Disponível em http://www.estadao.com.br/arquivo/arteelazer/2004/not20041201p4779.htm. Acesso em 01-06-2008. Outros sites entre tantos, que tratam ou trazem poemas, encontram-se em: http://www.lusofoniapoetica.com ; http://www.digestivocultural.com; http://www.sonetos.com.br; http://www.avbl.com.br (Academia Virtual Brasileira de Letras). Além desses sites ligados a grupos, há os blogs e os espaços dedicados a poetas já pertencentes ao cânone (como www.viniciusdemoraes.com.br) ou a poetas estreantes que encontram na internet a oportunidade negada em outros suportes como o do livro. Mais recentemente, houve a inserção e a circulação de poemas no Twitter (rede social que permite aos usuários a troca de informações sempre na forma de pequenos textos com até 140 caracteres, microblogs), caracterizadas como nova forma poética (http://www.livreshebdo.fr/actualites/DetailsActuRub.aspx?id=3190 , acesso em 13-07-2009). Não se trata de uma circulação avaliada como positiva ou negativa, refiro-me apenas ao volume e à diversidade de formas de circulação, que provam a longevidade do poema.
} 
PINHEIRO, 2003, PADILHA, 2005 entre outros), o poema não sofria apenas um deslocamento, tornando-se um gênero escolar; o que ocorria ${ }^{8}$ era o uso do poema como estímulo ou pretexto para outras atividades. Tratava-se de um texto de apoio, sem que sobre sua função, estrutura e significado fosse dedicada atenção suficiente. Essa posição conteudística assume o primeiro plano, relegando a totalidade significante do poema e as vozes envolvidas nessa totalidade a outro espaço, que os alunos podem ou não, recuperar.

Desse modo, ao definir o corpus para análise, distanciei-me do tratamento dado ao gênero no livro didático, por acreditar que o processo de mudança nesse âmbito estava em curso. As orientações dadas pelo MEC, partindo de uma proposta educacional maior envolvendo os PCN $(1997,1998 ; 2000)$ e outros documentos afins, modificaram as políticas editoriais de coleções didáticas, pois a aprovação desse órgão significa validação da obra e permite visibilidade. Assim, mesmo que não seja em ritmo acelerado, os ditames que envolvem o mercado permitem uma mudança mais efetiva. A aplicação desse material não está posta em questão, pois está vinculada a discussões de propostas educacionais como as do horizonte dessa pesquisa. No entanto, a qualidade do material e a forma como esse material articula as diferentes atividades e posturas em relação ao ensino da língua, via gênero, implicam a mudança de postura do professor, ou, pelo menos, geram um incômodo no momento de trabalhar com essa articulação de saberes no livro didático - um princípio de sensibilização para novos caminhos e estratégias. Dessa forma, identificar e discutir propostas capazes de envolver os componentes do processo do ensino do gênero merecia, para mim, ser o centro da reflexão.

A discussão se voltava, desse modo, ao processo de formação de professores-leitores de poemas, e, então, para o modo de auxiliá-los na dinâmica de sala de aula na formação dos alunos-leitores. A busca por essas propostas trouxe-me à memória um artigo de John Ciardi (1989), crítico literário da linha do New Criticism, tradutor e poeta para crianças, que formula este questionamento: "é possível dizer que ao professor falta um treinamento efetivo sobre a natureza da poesia porque os cursos de licenciatura têm uma noção vaga da natureza da poesia, e por isso o departamento de Língua Inglesa tem tendido a estudar tudo sobre a poesia

\footnotetext{
${ }^{8}$ As orientações para a avaliação dos livros didáticos pelas equipes do MEC baseadas nos PCNs trouxeram mudanças que se refletiram em algumas novas coleções didáticas, que buscam tratar o poema como gênero, colocando-o em suas unidades como centro das atenções.
} 
menos o poema em si?" ${ }^{9}$ Em razão da urgência que me movia, no momento em que comecei a pesquisa, uma vez que as mudanças nos cursos de Licenciatura são objeto de estudos interdisciplinares, além do âmbito do estudo do gênero específico a que me dedico, decidi buscar as possibilidades de atuar na capacitação desses professores, transversalmente, pela busca de uma forma de trabalho com o poema via gênero que requer do professor reflexão e construção de material específico para atender à classe real a sua frente além daquele fornecido pelo material didático.

\subsection{Achei um poema!}

Os modos de circulação do poema no espaço da escola e sua configuração como gênero escolar passaram ao centro da pesquisa, uma vez que era (e é ainda) possível constatar que muitos dos gêneros com os quais os alunos têm familiaridade são ou estão ainda bem próximos dos gêneros primários como os classificam Schneuwly e Dolz (2004, p. 30), na retomada que Bronckart realiza desses conceitos em Bakhtin: "enquanto os discursos primários seriam assim ‘estruturados pela ação', os discursos secundários (narração, discurso teórico etc.) dela se separariam e seriam submetidos a um estruturante próprio, convencional, de natureza especificamente linguística; eles seriam 'estruturados na ação"”. Assim, embora os alunos tivessem experiência com alguns gêneros (em geral, mais primários que secundários) ao entrarem na escola, o poema, em seus mais variados subgêneros, porque é sempre plural, parece ocupar um espaço relativamente pequeno. Principalmente porque os textos poéticos que circulam na escola estão marcados pela didatização ocorrida no livro texto e pela seleção prévia de certos períodos literários e autores.

A seleção, quando feita pelos professores, decorre de necessidades criadas pelo conteúdo programático, determinações hierarquicamente estabelecidas, que naturalizam, muitas vezes, a presença do poema desdobrado em funções didáticas. Essa inserção com viés utilitário ainda persiste, como se observa nas pesquisas, ainda que várias iniciativas em relação ao gênero tenham sido implementadas com sucesso. Um dos casos bem sucedidos

\footnotetext{
9 "Is it possible to say that a teacher lacks a real training in the nature of poetry because the schools of education have only the vaguest sense of the nature of poetry, and because the department of English have tended to study everything about the poetry except the poem itself?" (tradução nossa). Trata-se do parágrafo final do texto "Teaching poetry", um dos quinze ensaios que compõem o livro Ciardi Himself: fifteen essays in the reading, writing, and teaching of poetry, Fayetteville: The University of Arkansas Press, 1989.
} 
que afirma coexistirem posturas às vezes opostas (pró e contra poesia) encontra-se em Discurso e cultura na Aula de Língua (SERRANI, 2005), em cujas análises e questionamentos, a autora aponta para a quebra da dicotomia existente entre língua e literatura para a mais bem sucedida formação do professor.

Não pretendo, no entanto, menosprezar a importância do poema como forma didática, uma vez que concordo com Zélia Versiani, que, em seu artigo "A diversidade da produção poética para crianças e jovens", afirma: "que não existe poesia paradidática. Ela é antes 'didática', porque ensina com arte e não está a serviço de alguma coisa que se encontra fora dela. O que ela ensina não se traduz, ela só se diz através de si mesma, como ensinava Valéry." (2000, p. 57). O que ocorre, porém, é que a apresentação do poema acontece em páginas acrescidas de exercícios; ou de outros questionamentos, passando o texto poético a segundo plano. Ou seja, sua presença é como a de Hitchcock nos filmes, mas, contrariamente ao diretor de cinema inglês, não chega ao protagonismo mesmo que por alguns minutos.

A presença discreta do poema tem como consequência, em geral, uma não escolha por parte do aluno. A primeira providência, nesse cenário, é abrir clareiras para o poema, colocálo em murais, na sala, ler um poema por razão nenhuma, esquecer os exercícios que o acompanham vez ou outra, aceitar outras formas poéticas como a canção. Deixar o poema circular em espaços externos à sala de aula, como já dizia há mais de uma década, o pesquisador e professor Hélder Pinheiro, em seu livro, Poesia na sala de aula (1996), para que sua entrada seja menos didatizada e mais bem recebida.

A busca de situações que promovessem a entrada do poema, como gênero, favoreceu a escolha pela análise do Prêmio "Escrevendo o Futuro", edição 2004, por ter sido divulgado por todo o país, nas escolas estaduais, e por apresentar uma estrutura diversa de outros concursos, pois a inscrição inicial, feita pela escola e não, por um aluno determinado, representava apenas o começo de um percurso, uma vez que professores e alunos, assim como a comunidade, em momento posterior, deveriam seguir uma série de procedimentos indicados no material de orientação oferecido pelo CENPEC, o Kit Itaú de Criação de Textos, composto pelo caderno de orientações iniciais "Cá entre nós" (anexo 1); e por três outros fascículos: Pontos de vista (texto de opinião), Se bem me lembro (memórias) e Poetas da escola (poesia) (anexo 2), que indicavam como a produção do texto deveria ocorrer ${ }^{10}$. Depois de cumpridas as etapas, seria escolhido um texto, o finalista da escola, que passaria por outros

\footnotetext{
${ }^{10}$ No caso da pesquisa, analisou-se apenas o fascículo Poetas da escola, por tratar do gênero poético.
} 
momentos de circulação e avaliação no CENPEC, antes que se processasse a escolha final. Cada pólo, correspondente a estados ou regiões no território nacional, teria textos semifinalistas que circulariam antes dessa escolha, numa antologia do Projeto, promovendo a reintegração do poema, que havia se transformado de objeto de ensino, como gênero escolar, a gênero sem essa adjetivação principalmente para os leitores que não estavam envovidos com o prêmio na posição de avaliadores.

\subsection{Cá entre nós}

Na abertura do caderno de orientações iniciais, "Cá entre nós"11, o trabalho com cada um dos gêneros contemplados pelo prêmio "Escrevendo o futuro" é apresentado:

Escrever. Transformar pensamentos em palavras. Tirar o branco do papel e contar histórias sem fim. Misturar sentimentos com letras e construir uma poesia. Registrar para o mundo uma opinião. Transformar o lápis em uma lupa, investigar lugares e acontecimentos, produzir memórias, histórias de vida que nos levam a lugares e tempos desconhecidos." (CEN, p.1). (grifo nosso)

Dessa primeira aparição do poema ("Misturar sentimentos com letras e construir uma poesia"), surge a questão do sentimento como um guia para o fazer poético que corresponde a uma representação do poema como catalizador ou produto de emoções, uma maneira bastante redutora de uma concepção do ideário romântico, cujas formas de ação transformavam a forma do "eu" se posicionar num mundo em mudança e não em modos de colocar o que se sentia no papel (CAMPOS, 1969). Essa postura ou predominância de um certo lirismo não é exclusiva do Romantismo, servindo o lírico como um agrupamento de gênero, no nosso caso, o poético. Além disso, é possível pensar em qualquer um dos gêneros presentes no prêmio como uma forma de manifestar sentimentos, uma vez que não se suprime a afetividade das outras ações, não é possível compartimentá-las. Ao mesmo tempo, dizer que o poema tem como foco a emoção é negar as faces do texto poético.

Nessas orientações iniciais, a equipe do CENPEC identifica os suportes teóricos do projeto: “As atividades e orientações propostas estão sintonizadas com as diretrizes contidas nos currículos oficiais mais recentes da Língua Portuguesa, inclusive com os Parâmetros

\footnotetext{
11 Para diferenciar o caderno "Cá entre nós" do fascículo "Poetas da Escola" neste capítulo, eles serão identificados respectivamente por CEN e PDE.
} 
Curriculares Nacionais (PCN).” (CEN, p. 3) A preocupação com as correntes teóricas que ditam as formas de proceder e de entender o ensino de língua materna estão presentes nesse trecho. O uso das palavras "sintonizadas" e "mais recentes" parece dialogar com discursos provenientes das necessidades dos professores de responder às demandas de novas atividades, novas posturas, novos modos de atuar. Mais do que esclarecimento, a equipe, nesse trecho, parece afirmar seu posicionamento como suficiente e ciente do que rodeia a escola e o que lhe é solicitado, - uma forma de conseguir a adesão a uma proposta que requer envolvimento e trabalho intensos.

Da mesma forma que a descrição dos fascículos identifica as necessidades dos professores, coordenadores pedagógicos e diretores, em sua justificativa, os objetivos apresentados têm desdobramento secundário importante: a formação do professor. Essa tarefa, mais ambiciosa e de maior fôlego, se explicita em:

Esses fascículos significam uma contribuição do Prêmio Escrevendo o Futuro para o ensino da escrita na escola. (....) O alcance desse material vai para muito além do concurso, visa aprimorar o trabalho com a escrita, por isso pode ser aproveitado por todos que tenham interesse em melhorar a qualidade da educação pública brasileira. Ele poderá, inclusive, ser utilizado nas reuniões pedagógicas da escola." (CEN, p. $3)^{12}$

Nesse trecho, indica-se a urgência que a Comissão do Prêmio identifica por materiais que atendam às demandas de novas diretrizes dadas pelas instâncias superiores e, ao mesmo tempo, sem nomear a quem isso possa interessar (o pronome indefinido "todos" garante isso), projeta a idéia de que esse material ainda não existe na escola.

A projeção de uma imagem de suficiência do material e do percurso instituído pelo concurso nas páginas sucessivas do caderno "Cá entre nós" será transferida gradualmente para o trabalho a ser desenvolvido, assinalando a possível construção de uma potência e de um saber em espaço escolar via material do Prêmio. A condensação desse processo encontrase em duas afirmações. Uma, de caráter utópico, discurso situado fora da esfera ${ }^{13}$ do discurso escolar, da canção do "maluco beleza", Raul Seixas: "um sonho que se sonha junto é mais

\footnotetext{
${ }^{12}$ Hoje, segundo o site da Olimpíada de Língua Portuguesa, esse objetivo já foi alcançado, como se observa na notícia "Olimpíada estimula a formação do professor", do dia 27-02-2008, disponível em http://olimpiadadelinguaportuguesa.mec.gov.br/noticia/ver/5, acesso em 21-08-2008.

${ }^{13} \mathrm{O}$ conceito de esfera utilizado aqui pode ser determinado como: "campo / esfera é um espaço de refração que condiciona a relação enunciado / objeto do sentido, enunciado / enunciado, enunciado / co-enunciadores. (....) As esferas dão conta da realidade plural da atividade humana ao mesmo tempo que se assentam sobre o terreno comum da linguagem." (GRILLO, 2006, p.147)
} 
que um sonho é realidade" (CEN, p. 5) ${ }^{14}$. A outra, na forma de slogan, traz a esfera do discurso publicitário, estruturada em orações reduzidas, que, pelo uso do particípio, podem ser tomadas como sintagmas nominais (o que indicaria um processo já realizado pela natureza morfológica da estrutura - "organizada"; "divulgadas"; mobilizado"): "Escola organizada, informações divulgadas, grupo-escola mobilizado, é seguir em frente.” (CEN, p. 2). São duas maneiras de envolver o grupo com o Prêmio, o que indicaria que a esfera da reflexão teórica por si só não seria capaz de produzir a adesão necessária, segundo os organizadores. Se isso corresponde a uma imagem dos professores e diretores projetada no caderno "Cá entre nós", como imaginar que o trabalho possa ser desenvolvido de maneira produtiva, se o apelo foi feito de modo a atingir o pathos. ${ }^{15}$

No lugar de uma mobilização de saberes, surge a distribuição de tarefas, que passa a ser o ponto central para o desenvolvimento do concurso. Em, pelo menos, dois trechos, as palavras "fundamental" e "figura-chave" tentam persuadir e atribuir funções a professores e diretor, respectivamente: "Os professores têm papel fundamental nesse momento." (CEN, p. 4); e

O diretor da escola é figura-chave em todo o percurso do Prêmio na escola, no apoio aos professores, na busca de alternativas para superar eventuais dificuldades, nos esforços para mobilizar a equipe escolar e a comunidade em torno do processo e da aprendizagem da escrita, na divulgação das conquistas e das produções realizadas pelos alunos... Enfim, todo o seu empenho é fundamental! (CEN, p. 10)

A preocupação com o engajamento de todos, inicialmente responsabilidade do educador (ou educadores) que optou pela participação no concurso, é central para o projeto:

No entanto, se essa participação for um compromisso selado entre a escola e a comunidade, as chances de sucesso dos alunos, sem dúvida, serão muito maiores. Por isso mãos à obra!

Apresente o Prêmio Escrevendo o futuro para os professores, funcionários, alunos, pais e representantes da comunidade: seus objetivos, as etapas e prazos até a escolha dos vencedores; materiais de apoio etc.

Informe regularmente a comunidade escolar sobre o andamento das atividades desenvolvidas.

Organize uma Comissão Julgadora, com representantes da comunidade e da escola, que se encarregará de selecionar os textos que irão para as outras etapas do processo.

\footnotetext{
${ }^{14}$ A letra da canção de Seixas, "Prelúdio" (LP Gita, 1974), é: "Sonho que se sonha só/ É só um sonho que se sonha só / Mas sonho que se sonha junto é /realidade." Informações disponíveis em http://www.raulrockclub.com.br/index_old.html Acesso em 12.01.2009.

15 A noção de pathos, entendida aqui como na Análise do Discurso, ou seja, "utilizada para assinalar as discursivizações que funcionam sobre efeitos emocionais com fins estratégicos." (MAINGUENEAU; CHARADEAU, 2004, p. 372).
} 
Divulgue os textos produzidos pelos alunos, se possível, no jornal da cidade. (CEN, p. 2)

Essa convocação desde a primeira página aponta para a compreensão da escrita como um processo que não fica restrito às aulas de língua materna, e, ao mesmo tempo, indica que ao professor responsável por essa disciplina cabe sistematizar a presença reticulada da escrita no espaço da escola-comunidade.

Quanto mais o ensino da escrita envolver o coletivo dos professores, maiores serão
os avanços dos alunos na apropriação dessa habilidade. Assim, é interessante que os
professores de todas as disciplinas integrem-se às oficinas, por exemplo: o professor
de Geografia pode realizar um estudo do meio com os alunos; o de História pode
colaborar no levantamento da história da cidade e de histórias de vida, orientando os
alunos a realizarem uma análise das condições ambientais da cidade etc. (CEN, p.
4)

São muitas as formas da escrita contidas nessas sugestões que podem construir repertório para uma produção posterior, rompendo com a solidão da escrita como função primordial da aula de língua materna, ao contrário da realidade em que se observa essa profusão em momentos da escola e esferas diversas.

Além dos objetivos, o caderno apresenta a estrutura de trabalho a ser desenvolvida:

Cada um dos fascículos apresenta oficinas detalhadas em atividades com os respectivos objetivos e a descrição de situações e tarefas para que os professores possam favorecer vivências e orientar seus alunos a: conhecerem melhor o lugar onde vivem, apropriarem-se das características dos gêneros priorizados, produzirem seus textos e auto-avaliarem a escrita elaborada. (CEN, p. 3)

Essa estrutura corresponde em parte à organização das sequências didáticas, definida por Schneuwly e Dolz como "um conjunto de atividades escolares organizadas, de maneira sistemática, em torno de um gênero textual oral ou escrito.” (2004, p. 97) O conjunto de atividades permite que o processo de transposição ocorra no ambiente escolar sustentando a aplicabilidade do ensino do gênero. Identificar essa abordagem possibilitou, neste trabalho, a adoção de critérios de maior aderência para a compreensão do processo e dos resultados obtidos no Prêmio em relação ao ensino do poema.

Antes de iniciarem o trabalho em sala de aula, os professores deviam avaliar as propostas, pois, segundo as orientações, assim estariam "em condições de encaminhar a discussão com os alunos e de integrá-los para a escolha da alternativa mais adequada às características de cada grupo-classe.” (CEN, p. 4).

A entrada do professor em sala com a proposta e a escolha dos alunos por um dos gêneros é também o início do trabalho com o fascículo "Poetas da Escola", que, de forma 
mais clara, indica que o Prêmio tem como base a abordagem com os gêneros, na linha sóciodiscursiva. ${ }^{16}$

O fascículo "Poetas da Escola" era composto pela apresentação e 13 oficinas em que se alternavam o estudo das características formais do gênero com outros espaços de reflexão e discussão estabelecendo diálogos com as posições, opiniões e obras de autores consagrados ou não, presentes no dia-a-dia do aluno.

A essa orientação, acrescentavam-se a necessidade de deixar claro para os alunos os objetivos do trabalho com o gênero, e de se manter uma pasta de trabalho da classe, com todas as versões dos poemas produzidos em sala. Além disso, alguns professores (essa documentação era optativa) aderiram ao convite de elaborar relatos sobre a aplicação das oficinas, que acabaram por permitir a reconstrução de sua atuação e de seus alunos:

O acompanhamento do progresso dos alunos, por meio de registros sistemáticos de avanços e dificuldades observados, e a organização de uma pasta com as produções da classe, subsidiarão os professores no planejamento de novas intervenções visando ao contínuo aperfeiçoamento da produção escrita de todos os alunos. (CEN, p. 4)

O portfólio permite ao aluno recuperar suas produções, escrevendo e reescrevendo para definir, em alguns percursos, sua "obra-prima" (termo utilizado por Jolibert, 1994, para designar o texto considerado pelo aluno como final dentro de um canteiro) e, em outros casos, a produção final, que fazem parte das atividades denominadas Sequência Didática, a serem desenvolvidas na seguinte esquematização:

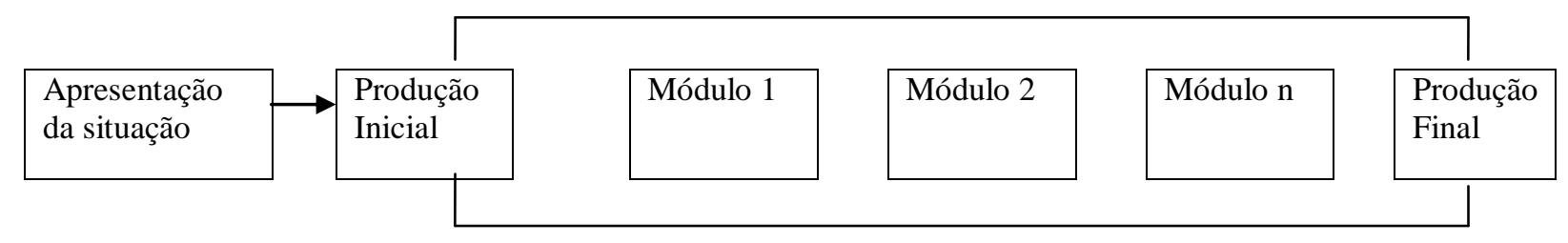

(SCHNEUWLY; DOLZ, 2004, p. 98)

Essa estrutura é seguida no fascículo "Poetas da Escola". A "apresentação da situação" está caracterizada pelo próprio fascículo, ao lado de um trabalho intenso que cada professor teria promovido ao estimular a turma para a adesão ao prêmio. O essencial nessa etapa foi esclarecer as condições de produção da escrita:

Para escrever seus textos, eles devem saber dessas condições desde o início: suas escritas terão uma finalidade (convencer alguém de alguma coisa ou resgatar a

\footnotetext{
${ }^{16}$ Adoto a divisão em grupos apresentada em MEURER; BONINI; MOTTA-ROTH, 2005, em que a abordagem de Schneuwly, Dolz, Bronckart e Adam encontram-se na linha sócio-discursiva.
} 
memória sobre histórias ou fatos interessantes do lugar onde vivem para pessoas que querem conhecê-los ou sensibilizar o leitor), serão publicadas e lidas por muitas pessoas. (PED, p. 2) (grifo nosso)

Se a preparação para o evento de escrita parece ter sido atendida de maneira satisfatória (identificar e estabelecer com os alunos ou, nesse caso, para os alunos - pois, no prêmio, já estavam definidas as condições), o modo como a finalidade foi explicitada, entre parênteses, indica que, para o poema, o objetivo era "sensibilizar o leitor". Essa meta, diante das outras apresentadas, limita a representação do gênero para o professor. A sensibilização pode se tornar uma etapa ou estratégia em inúmeros gêneros e pode promover uma certa opacidade em relação ao poema. Como afirmam Schneuwly e Dolz: "A apresentação da situação é, portanto, o momento em que a turma constrói uma representação da situação de comunicação e da atividade de linguagem a ser executada. (2004, p. 99) Se a própria situação não estiver clara, como representar o gênero de maneira adequada? Será o gênero, da esfera do literário, o problema nesse caso?

Ainda nessa etapa, aos alunos foram apresentados exemplos do gênero em questão. Essa exposição tinha a finalidade de estimular a formação ou explicitação de representações que poderiam ser esclarecidas e modificadas de acordo com o estabelecimento dos conteúdos da Sequência Didática. Aqui se encontra o caráter fundamental da participação do professor. A avaliação de cada docente a respeito das representações poderia guiar o modo como as oficinas seriam desenvolvidas (uma vez que já estavam definidas), ou melhor, adaptadas às necessidades da turma. Porém, se o professor se ativesse ao fato de que o aluno precisava apresentar um texto que se caracterizasse como finalista, o trabalho em si seria obstaculizado, porque a sequência didática, embora apresentasse (apresente) como meta o sucesso, tinha como princípio básico trabalhar diferentes percursos de construção da escrita, respeitando as diferenças entre os alunos, possibilitando o aproveitamento de diferentes posições em relação ao gênero e a proficiência em relação aos elementos linguísticos e discursivos, que não acontece de modo linear nem em ritmo semelhante.

Um elemento, no entanto, poderia atenuar os efeitos da cristalização de um objetivo como a premiação final - o estabelecimento de leitores externos ao espaço da sala de aula. 
O material evidenciou, desde as orientações iniciais, com caráter de sugestãocondição, como os promotores do prêmio entendiam, naquele momento ${ }^{17}$, a questão do ensino da escrita. A atitude requerida nesse item do material de orientação provia e promovia a criação de um público leitor que não o "institucional" - pais, funcionários da escola e outros membros da comunidade eram convidados a assumir a posição de leitores. Esse dado parece essencial, pois, para que se estabeleça a autoria, é necessário que se tenha um leitor, um interlocutor suficiente e legitimado que, em atitude responsiva, já desde o início, "converse" com o autor do texto.

Como os alunos e professores reagiriam a essa presença? A presença do leitor externo é sempre uma expectativa difícil de ser incorporada pelos alunos, mais difícil ainda de ser elaborada nos textos, principalmente por não se apresentar como elemento habitual em ambiente escolar, embora seja pressuposto da interação no gênero.

Esse leitor permite a criação das condições que envolvem o gênero fora dos muros da escola, no espaço social mais amplo, resultando, por meio da transposição didática, em maior aproximação da realidade - objetivo traçado no fascículo "Cá entre nós - orientações iniciais", em que se lia:

De fato, a participação nesse processo de formação e inscrição no concurso pode ter sido uma decisão de alguns educadores, provavelmente daqueles que irão realizar o trabalho. No entanto, se essa participação for um compromisso selado entre a escola e a comunidade, as chances de sucesso dos alunos, sem dúvida, serão muito maiores. (CEN, p. 1)

Além disso, esse leitor além do espaço da sala de aula instituiu como fator não habitual a ser trabalhado na apresentação do gênero, uma questão importante: clarificar a decisão didática, muitas vezes, não explícita de introdução de um gênero na escola, decisão que, por vezes, apaga lugares sociais onde o gênero realmente circula. Essa transposição didática, ou seja, o transporte de um gênero que funciona em outro lugar social representa uma transformação. Segundo Schneuwly e Dolz,

ele (o gênero) não tem mais o mesmo sentido; ele é, principalmente, sempre - nós
acabamos de dizê-lo - gênero a aprender, embora permaneça gênero para
comunicar. É o desdobramento, do qual falamos mais acima, que constitui o fator
de complexificação principal dos gêneros na escola e de sua relação particular com
as práticas de linguagem. Trata-se de colocar os alunos em situações de
comunicação que sejam o mais próximas possível de verdadeiras situações de
comunicação, que tenham sentido para eles, a fim de melhor dominá-las como

${ }^{17}$ O Prêmio a cada edição traz adequações para que a proposta possa ser atendida nos parâmetros do trabalho com o gênero. Além disso, nos anos ímpares, 2005, por exemplo, as escolas participantes formavam grupos que se debruçavam sobre questões surgidas da avaliação do Prêmio, tanto em relação aos textos como também aos percursos observados. 
realmente são, ao mesmo tempo sabendo, o tempo todo, que os objetivos visados são (também) outros. (2004, p. 81)

Porém, contrariamente às situações de transposição didática "pura", o papel do leitor externo abre espaços na "bolha" criada pela transposição didática, pois ele é real e determina dois tempos e espaços para o trabalho. A transposição só funciona de um certo modo quando não há nenhuma possibilidade de haver cruzamentos imediatos. $\mathrm{O}$ espaço fora da escola é trazido pelas condições instauradas nas atividades propostas pelo professor. No caso do Prêmio, as esferas se cruzam desde o princípio. Há uma esfera criada virtualmente, no evento escolar; e outra, fora dele. As interferências de uma sobre outra podem ser um fator de complexidade, uma vez que o professor não está acostumado a lidar com elas ao mesmo tempo. Seria possível neutralizá-las, acomodando-as em momentos diversos? Essas esferas com áreas superpostas poderiam, por sua topografia, eliminar a questão dos momentos? Seria um aqui e agora, ou seria um aqui para um agora "posterior”? No capítulo de análise será possível verificar se isso foi um fator relevante para a elaboração do texto.

No prêmio, as oficinas direcionavam os alunos ao tema "O lugar onde vivo" e ao gênero escolhido, propondo levar os alunos a: 1) conhecerem melhor o lugar onde vivem;2) apropriarem-se das características dos gêneros priorizados; 3) auto-avaliarem a escrita elaborada.

Os objetivos remetiam a uma das questões centrais do gênero: a agência. O gênero é essencial para a interface com o mundo, pois envolve situações, formas, ações e motivos, promovendo "compreensão, coordenação e cooperação mútuas - mesmo como parte da criação de posições opostas ou diferenciadas.” (BAZERMAN, 2007, p. 22) Para que os objetivos se efetivassem (e nesse caso, a criação de posições, um amadurecimento promovido na ação por meio da escrita no gênero), as oficinas precisavam promover a avaliação do tema (e situações); o uso das formas; permitindo a elaboração de motivos que decorressem da posição de sujeito.

É possível, nessa chave de compreensão do trabalho poético, associá-la ao conceito de autoria na linha bakhtiniana, como afirma Faraco:

O autor-criador é, assim, quem dá forma ao conteúdo: ele não apenas registra passivamente os eventos da vida (ele não é um estenógrafo desses eventos), mas, a partir de uma certa posição axiológica, recorta-os e reorganiza-os esteticamente. 
$\mathrm{O}$ ato criativo envolve, desse modo, um complexo processo de transposições refratadas da vida para arte: primeiro, porque é um autor-criador e não o autorpessoa que compõe o objeto estético (há aqui, portanto, já um deslocamento refratado à medida que o autor-criador é uma posição axiológica conforme recortada pelo autor-pessoa); e, segundo, porque a transposição de planos da vida para a arte se dá não por meio de uma isenta estenografia (o que seria impossível na concepção bakhtiniana), mas a partir de um certo viés valorativo (aquele consubstanciado no autor-criador) $(2005$, p. 45)

Para que os objetivos fossem alcançados, era importante verificar como os textos seriam avaliados, pois os critérios de avaliação eram a segunda baliza para que o professor delineiasse caminhos dentro da dinâmica da sala de aula.

A comissão julgadora (composta por um representante dos pais, um representante dos professores, não envolvido diretamente com o concurso, um representante dos alunos, igualmente não envolvido com ele, um morador da cidade que utilize a escrita no seu trabalho e um integrante da direção da escola) recebia, no Kit, os seguintes critérios: a) "pertinência ao tema proposto"; b) "observação dos elementos da poesia"; c) "busca e informações sobre o tema" e d) "originalidade", assim caracterizados:

\section{Poema}

A avaliação deve considerar, sobretudo, se o texto traz inspiração e desperta emoção. $^{18}$

\begin{tabular}{|c|c|}
\hline \multicolumn{2}{|c|}{ Os 10 pontos ficam, assim, divididos } \\
\hline $\begin{array}{l}2,5 \text { Pertinência ao tema } \\
\text { proposto }\end{array}$ & $\begin{array}{l}\text { - o poema está apropriado ao tema } \\
\text { estabelecido - "O lugar onde vivo" -, } \\
\text { compreendendo não só a cidade, mas o } \\
\text { bairro, a rua, os locais interessantes e seus } \\
\text { moradores, cultura e peculiaridades }\end{array}$ \\
\hline $\begin{array}{l}2,5 \text { Observação dos } \\
\text { elementos da poesia }\end{array}$ & $\begin{array}{l}\text { - o poema tem título e é sugestivo; } \\
\text { - mostra um conjunto que produz um sentido; } \\
\text { - o poema apresenta alguns dos recursos } \\
\text { poéticos trabalhados nas oficinas; } \\
\text { - estes recursos despertam a sensibilidade do } \\
\text { leitor. }\end{array}$ \\
\hline $\begin{array}{l}2,5 \quad \text { Busca das } \\
\text { informações sobre } \quad 0 \\
\text { tema }\end{array}$ & $\begin{array}{l}\text { - o texto deixa transparecer que o autor } \\
\text { observou um aspecto especial do lugar onde } \\
\text { vive e conseguiu expressá-lo }\end{array}$ \\
\hline
\end{tabular}

18 Grifos meus, para ressaltar que "inspiração" e "emoção" são elementos vagos para serem critérios de avaliação, uma vez que instauram a questão da subjetividade como inicial, abrindo espaços para além do desejável em avaliações. Há um papel inevitável para a subjetividade dos componentes da banca quando se avalia, porém mesmo sendo inevitável, a sua validade é mantida como aceitável pela presença dos critérios “objetivos” para que se sustente a avaliação como possível em todos os objetos de um grupo. 


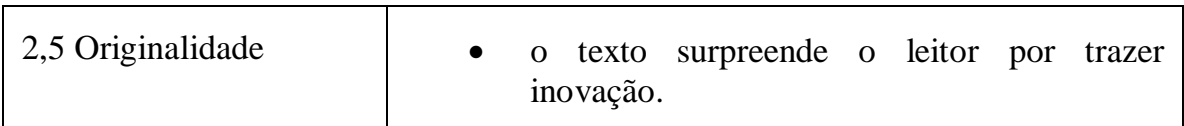

(CEN, p. 6)

O conjunto dos critérios permitia identificar as noções norteadoras do que se estabeleceu como gênero poético no Prêmio. O critério "pertinência ao tema proposto", embora abrangente permitindo ao aluno um espaço de circulação bastante amplo no tema, podia remeter a outros gêneros (como os publicitários, os de folheto e catálogo, os de revistas sobre turismo). Essa direção estaria subentendida na forma como se adjetivou o substantivo "locais" (interessantes) e no emprego do substantivo "peculiaridades", uma vez que este possui, segundo o dicionário on-line Houaiss, uma carga positiva ("qualidade ou condição do que é peculiar; característica de alguém ou de algo que se distingue por traços particulares; originalidade, singularidade, particularidade") e outra neutra ("traço peculiar, próprio de alguém ou de algo; característica, modalidade"). O emprego dessas palavras pôde reforçar a impressão de que o tratamento deve ser, de algum modo, laudatório. O mesmo ocorreu no critério "Busca de informações sobre o tema", em que o uso de "aspecto especial do lugar" indicava a necessidade de um posicionamento positivo, pois "especial" apontava para a relevância de algo, que se destaca do geral por sua especificidade, e, no critério "Originalidade", a exigência de surpreender o leitor pela inovação não corresponde a um critério do gênero em si, mas podia ser associada à concepção de novidade:

A novidade é o aspecto mais universal do ser: todos os seres do mundo se revestem dela, pelo simples fato de que, ao surgirem para o sujeito, eles eram desconhecidos.

O grau de novidade dos seres é medido em função do conhecimento anterior de quem o capta: o novo é sempre o até então desconhecido. (....) (LIRA, 1986, p. 12)

Além da associação com a novidade, a "originalidade" estaria ligada com o arranjo inédito dos elementos que se referem à estrutura composicional e temática do gênero escolhido. Mesmo nesse caso, seria um critério difícil de preencher uma vez que os alunos participantes têm um repertório menor do que os adultos. Certos topoi, certas construções, certas imagens poderiam ser inéditas para eles e já conhecidas por aqueles que avaliam o poema. Aliada a esse fato está a questão de que os gêneros da esfera do literário envolvem tradição e inovação, promovendo um diálogo que se caracteriza pela maneira como os sujeitos vêem as questões sociais, históricas e ideológicas daquele momento fazendo-os interagir tanto com momentos e questões já vividas quanto outros imaginados, porque estão por vir. 
Por fim, o critério "Observação dos elementos da poesia" estabelece a presença do título, o fato de ser sugestivo, e o uso dos recursos apresentados nas oficinas (rimas, assonâncias e aliterações, figuras de linguagem - similaridade) como necessários para a avaliação positiva do poema. Novamente há uma coincidência de elementos que não caracterizam necessariamente enunciados dos gêneros poéticos. Se for adicionado a isso a necessidade de o título ser sugestivo, são estabelecidas instruções para a produção textual de vários gêneros, pois os textos devem ter elementos estruturais que consigam a adesão do leitor. Quanto ao uso desses recursos, os apresentados nas oficinas levam a uma concepção dos gêneros poéticos de base formal, uma vez que a poesia não pode ser entendida como o texto que possui rimas, aliterações, assonâncias e figuras de linguagem. ${ }^{19}$

Esses critérios, ainda que tivessem aderência aos trabalhos desenvolvidos nas oficinas, não retomavam as experiências, também presentes nas oficinas, em relação ao sujeito que vê o entorno, absorve-o, devolvendo-o de forma a evidenciar um trabalho sobre o espaço em que vive e a linguagem que usa, como se observa em um trecho da seção "Dica para o professor", da oficina 2 ,

Existe em nossa cultura uma crença muito arraigada de que função da poesia é cantar amores ou exaltar o belo. É importante ajudar seus alunos a ultrapassar essa crença e compreender que, na verdade, a poesia traduz em palavras a maneira como o poeta olha o mundo. (grifo nosso) (PDE, p. 13)

As representações da poesia (palavra em relação sinonímica com poema nesse e em outros trechos do Caderno e do Fascículo) indicavam que há dois modos de compreender o que é o poema, ora confundindo-o com a produção lírico-amorosa ora apresentando uma concepção mais abrangente. Essa segunda linha previa o desenvolvimento da autoria, da voz que assumiria a articulação do mundo ao redor, atribuindo valor a esse mundo.

No Fascículo, a análise das oficinas esclareceu o quanto o embate dessas posições promovia ou não a formação das representações dos gêneros poéticos presentes nos poemas dos alunos, permitindo a assunção da autoria.

\footnotetext{
19 A discussão sobre como os elementos formais não podem se constituir como caracterizadores únicos da poesia aparece em TEZZA, 2003 e é uma das questões a serem discutidas no capítulo 3.
} 


\subsection{Poetas da Escola}

As oficinas no fascículo eram precedidas por três apresentações. O primeiro texto "Apresentação" propriamente dita, de cunho institucional, situava o Prêmio dentro de um programa de intervenção para a "melhoria da produção escrita nas escolas públicas brasileiras" (PDE, p. 1), indicando que, nos anos pares, o programa premiaria os alunos, professores e escolas, e, nos anos ímpares, haveria um trabalho de formação dos professores quanto ao ensino da leitura e da escrita. Por ser assinada pelo Presidente da Fundação Itaú Social, enfatizavam-se as parcerias e apresentavam-se os números que subentendiam o cumprimento das metas do programa, uma forma de legitimação para aqueles que se vinculavam, naquele momento, à edição de 2004.

O segundo, "Carta ao Professor", era a apresentação das autoras do fascículo que indicavam como devia ser desenvolvido o trabalho, em seus aspectos gerais, para os três gêneros. Elas mostravam, nesse espaço, os pressupostos: "Cada um desses gêneros de textos tem uma finalidade bastante diferente, o que determina que tenham de apresentar características bem particulares.” Essa caracterização está em consonância com o conceito de gênero, segundo Bakhtin, que, sempre em processo e como num mosaico, o apresenta ao longo do capítulo "os gêneros do discurso" (e em muitos outros textos ao longo de sua reflexão teórico-filosófica), como em:

Uma determinada função (científica, técnicas, publicística, oficial, cotidiana) e
determinadas condições de comunicação discursiva, específicas de cada campo,
geram determinados gêneros, isto é, determinados tipos de enunciados estilísticos,
temáticos e composicionais relativamente estáveis. (BAKHTIN, 2003, p. 266)

Dessa forma, pôde-se vincular a "finnalidade" ao domínio da função, e as "características bem particulares" ao dos elementos estilísticos, temáticos e composicionais. Quanto a "determinadas condições de comunicação discursiva", a menção a elas não é explícita e pôde ser recuperada parcialmente quando as autoras indicaram a importância do leitor e dos espaços de circulação do texto:

Muitas vezes, quando propomos que nossos alunos escrevam, não damos a essa escrita uma finalidade clara, nem estimulamos sua circulação fora da escola. Os leitores das produções escritas realizadas na escola são, quase sempre, apenas os professores. A redação é feita na escola e para a escola. Isso contribui para padronizar as produções escolares, deixando-as muito parecidas entre si. (PDE, p. 2) 
Embora a carta não fosse o espaço para a discussão dos fatores condicionantes pelo volume que ocupava no fascículo, o silenciamento parcial em relação a eles, pois não apareciam nas oficinas, levou, em alguns momentos, a um apagamento dessas condições na escrita dos alunos, pois a finalidade e as características do poema assumiram o primeiro plano.

O terceiro texto, "Apresentação ao aluno", era um guia para o professor, com sugestões e indicações para a atuação em sala de aula. Segundo a apresentação, o professor precisava, para o bom andamento das atividades, se familiarizar com o material (textos, livros, vida dos poetas, glossário e afins) e estabelecer os "combinados" com os alunos, caracterizados como "regras e normas de organização que deveriam ser observadas pelos alunos e cobradas por você" (PDE, p. 5). Na "Carta ao professor", predominava o "nós" inclusivo, um alinhamento das autoras com os professores. Já na “Apresentação ao aluno”, o que predominava era o "você" (professor), com um caráter mais operacional. Essa mudança de interlocutor poderia gerar uma quebra entre o discurso formado pela instância institucional (primeiro e segundo textos) que não era estranha às atividades que se desdobram desde a formação do professor, chegando à aplicação em sala de aula. De certa forma, o professor se sente dessa maneira, ora incluído e em processo, em papel mais ativo, ora colocado na posição de receptor. Essa tensão, por vezes, interfere no ato de assumir as atividades em sala como agente. Lembra a situação da criança que, embora deseje ficar sozinha com a bicicleta e partir sem apoio para os caminhos que deseja trilhar, acaba por olhar para trás sentindo-se segura somente quando enxerga o apoio.

As oficinas tinham como foco de trabalho os seguintes temas e objetivos:

\begin{tabular}{|c|c|}
\hline Oficina & Objetivo \\
\hline 1. Reconhecendo poesia & $\begin{array}{l}\text { Resgatar a experiência dos alunos, } \\
\text { possibilitando o reconhecimento das } \\
\text { diversas formas de expressão da poesia } \\
\text { no cotidiano. }\end{array}$ \\
\hline $\begin{array}{l}\text { 2. Sabendo um pouco mais sobre } \\
\text { poesia }\end{array}$ & $\begin{array}{l}\text { Refletir sobre as características da } \\
\text { poesia, definindo e diferenciando alguns } \\
\text { conceitos do universo poético (poesia, } \\
\text { poemas, rimas, versos, estrofes). }\end{array}$ \\
\hline 3. Produção individual & $\begin{array}{l}\text { Propor a produção de um primeiro } \\
\text { poema para avaliar o que os alunos já } \\
\text { sabem e os pontos que precisam ser } \\
\text { mais trabalhados. }\end{array}$ \\
\hline 4. Catadores de poemas & $\begin{array}{l}\text { Pesquisar poemas conhecidos pelas } \\
\text { pessoas das comunidades onde vivem } \\
\text { os alunos. }\end{array}$ \\
\hline $\begin{array}{l}\text { 5. Ouvindo, lendo e conhecendo } \\
\text { um pouco mais de poesia }\end{array}$ & $\begin{array}{l}\text { Conhecer alguns poemas consagrados } \\
\text { da língua portuguesa. }\end{array}$ \\
\hline 6. Brincando com as emoções e as & Sensibilizar o aluno para perceber, \\
\hline
\end{tabular}




\begin{tabular}{|c|c|}
\hline palavras & identificar e criar rimas. \\
\hline $\begin{array}{l}\text { 7. Brincando um pouco mais com } \\
\text { as palavras: rimas, repetições e } \\
\text { aliterações }\end{array}$ & $\begin{array}{l}\text { Identificar o uso dos recursos poéticos: } \\
\text { rima, aliteração e repetição de versos. }\end{array}$ \\
\hline 8. Conhecendo poesia popular & $\begin{array}{l}\text { Familiarizar o aluno com poesia popular } \\
\text { e com mais um recurso poético: o } \\
\text { acróstico. }\end{array}$ \\
\hline $\begin{array}{l}\text { 9. Vendo o mundo de um modo } \\
\text { poético }\end{array}$ & $\begin{array}{l}\text { Possibilitar a identificação e criação de } \\
\text { comparações, imagens e metáforas em } \\
\text { poemas. }\end{array}$ \\
\hline $\begin{array}{l}\text { 10. Analisando diferentes olhares } \\
\text { sobre o mesmo tema }\end{array}$ & $\begin{array}{l}\text { Conhecer poemas de diferentes autores } \\
\text { sobre um mesmo tema - "o lugar onde } \\
\text { vivem ou viveram os poetas". }\end{array}$ \\
\hline $\begin{array}{l}\text { 11. Reconhecendo emoções e } \\
\text { sentimentos, tornando-se poeta }\end{array}$ & Elaborar poemas em pequenos grupos. \\
\hline 12. Tecendo poemas & Produzir a escrita individual. \\
\hline 13. Dando o toque final aos poemas & Rever os poemas produzidos. \\
\hline
\end{tabular}

(PDE, p. 6)

Como essas oficinas não foram desenvolvidas pelos professores, seria possível esperar que houvesse a necessidade de muitas adaptações na apresentação e na operacionalização das oficinas. Principalmente, porque segundo Schneuwly e Dolz, a apresentação do gênero a ser trabalhado e a primeira produção, "constituem momentos privilegiados de observação, que permitem refinar a sequência, modulá-la e adaptá-la de maneira mais precisa às capacidades reais dos alunos de uma dada turma." (2004, p. 102). Assim, assumir o papel de agente é essencial ao professor, uma vez que ele poderá determinar o tempo em cada oficina e o papel de cada atividade e leitura. Fazê-lo compreender seu papel, porém, talvez não fosse assim tão simples, pois, ao lado da tarefa maior ("contribuir para a melhoria da qualidade da educação brasileira", PDE, p. 3), estavam a premiação e as expectativas dele e dos alunos. Um percurso mais simples e aparentemente uma garantia de sucesso para alguns professores seria cumprir todas as atividades. Contrariamente a essa tendência, a leitura crítica do material proposto para o professor possibilitaria (e em alguns casos o fez) alcançar esse "sucesso" de maneira mais efetiva.

A questão aqui era como enfrentar a pressão discursiva colocada no material de apresentação, caderno e fascículo. Pelos trabalhos na área de linguística aplicada que envolvem a formação de professores (ROJO, 2005; KLEIMAN, 2006; MATÊNCIO, 2006), é possível determinar algumas direções apresentadas pelos professores em cursos, oficinas e atividades afins - condensadas no desejo de um material aplicável e de resultado concreto. Como as oficinas apresentavam várias atividades, isso poderia inibir a criação de um foco. 
Para identificar como essa dispersão ocorria em alguns momentos, foi feita uma análise macroestrutural da Sequência e outra com comentários específicos sobre cada uma das oficinas.

Ao analisar a macroestruturação das oficinas segundo a organização das Sequências Didáticas (SD), é possível observar de forma pontual:

\begin{tabular}{|c|c|c|}
\hline OFICINAS & OBJETIVOS & SD \\
\hline 1. Reconhecendo poesia & $\begin{array}{l}\text { Resgatar a experiência dos alunos, } \\
\text { possibilitando o reconhecimento } \\
\text { das diversas formas de expressão } \\
\text { da poesia no cotidiano. }\end{array}$ & \multirow[t]{2}{*}{ Apresentação da situação } \\
\hline $\begin{array}{l}\text { 2. Sabendo um pouco } \\
\text { mais sobre poesia }\end{array}$ & $\begin{array}{l}\text { Refletir sobre as características da } \\
\text { poesia, definindo e diferenciando } \\
\text { alguns conceitos do universo } \\
\text { poético (poesia, poemas, rimas, } \\
\text { versos, estrofes). }\end{array}$ & \\
\hline
\end{tabular}

- que o fato de existirem duas oficinas destinadas a essa apresentação auxilia o professor a interagir de forma mais eficiente com os alunos, adequando as atividades apresentadas ao universo deles. Também é relevante o fato de partirem dos gêneros primários (experiências com parlendas, adivinhas e afins) ou gêneros de circulação local (cordel, quadras etc.);

3. Produção individual $\quad$ Propor a produção de um primeiro poema para avaliar o que os alunos já sabem e os pontos que precisam ser mais trabalhados.

- que, nesse ponto, há a coincidência das duas estruturações;

\begin{tabular}{|c|c|c|}
\hline 4. Catadores de poemas & $\begin{array}{l}\text { Pesquisar poemas conhecidos pelas } \\
\text { pessoas das comunidades onde } \\
\text { vivem os alunos. }\end{array}$ & \\
\hline $\begin{array}{l}\text { 5. Ouvindo, lendo e } \\
\text { conhecendo um pouco } \\
\text { mais de poesia }\end{array}$ & $\begin{array}{l}\text { Conhecer alguns poemas } \\
\text { consagrados da língua portuguesa. }\end{array}$ & Mlodulo 1 \\
\hline
\end{tabular}

- que, embora pareçam dois momentos diversos, ambos têm em comum o fato de que os alunos passam a conhecer a produção nos gêneros poéticos. A junção de escolhas provenientes de diferentes espaços de circulação estimula a aproximação dos alunos com esses gêneros, pois não se trata apenas de autores consagrados provenientes de espaços de circulação legitimados por um grupo maior de pessoas; a produção de pessoas da comunidade inicia um processo de legitimação da voz dos alunos também.

6. Brincando com as Sensibilizar o aluno para perceber, emoções e as palavras identificar e criar rimas.

7. Brincando um pouco Identificar o uso dos recursos 


\begin{tabular}{|c|l|l|l|}
\hline $\begin{array}{l}\text { mais com as palavras: } \\
\text { rimas, repetições e } \\
\text { aliterações }\end{array}$ & $\begin{array}{l}\text { poéticos: rima, aliteração e } \\
\text { repetição de versos. }\end{array}$ & Módulo 2 \\
\hline 8. & $\begin{array}{l}\text { Conhecendo poesia } \\
\text { popular }\end{array}$ & $\begin{array}{l}\text { Familiarizar o aluno com poesia } \\
\text { popular e com mais um recurso } \\
\text { poético: o acróstico. }\end{array}$ & Módulo 3 \\
\hline 9. Vendo o mundo de & $\begin{array}{l}\text { Possibilitar a identificação e e } \\
\text { criação de compaçaçes, imagens e } \\
\text { metáforas em poemas. }\end{array}$ & Módulo 4 \\
\hline
\end{tabular}

- que os módulos 2, 3 e 4 tratam da estrutura composicional e colocam em foco elementos que podem identificar (mas não exclusivamente) o poema, pois também podem aparecer em outros gêneros como as canções, os jingles, alguns slogans de campanhas publicitárias etc. Esse caráter aberto é evidenciado de forma mais clara no módulo 4 com a identificação de figuras de linguagem que podem aparecer de modo semelhante nos gêneros prosaicos, pois o que se trabalha na oficina é a estruturação da metáfora.

10. Analisando diferentes Conhecer poemas de diferentes olhares sobre o autores sobre um mesmo tema - "o mesmo tema $\quad$ lugar onde vivem ou viveram os poetas".

Módulo 5

- que o módulo 5 retoma o modo de apresentação do módulo 1, trazendo (sempre na perspectiva em espiral) o afunilamento da questão do tratamento do tema nos gêneros poéticos. O que antes (módulo 1) teve como objetivo proporcionar visibilidade de alguns poetas com os quais os alunos poderiam se familiarizar, agora se desloca para a apresentação de autores consagrados como um aprofundamento. Na organização da $\mathrm{SD}$, ao apresentar o gênero a ser trabalhado, há também a indicação do "texto de referência" (JOLIBERT, 1994), porém, nesse caso, pela presença de inúmeros poemas e poetas (nove ao todo) há a dispersão da ideia de texto para se escrever "à moda de". Não há condições de se estabelecer um foco.

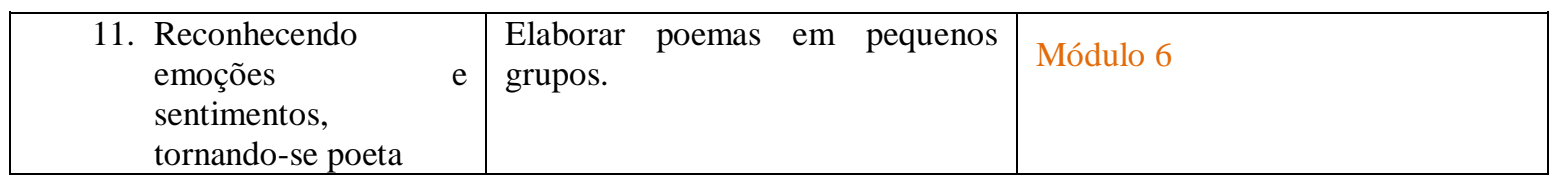

- que essa oficina não está prevista para esse momento da organização da SD. As produções em grupo em geral são introduzidas em módulos intermediários, que distam da produção final, para que haja a possibilidade de retomada dos processos autorais uma vez que os colegas funcionam como parceiros na produção em grupo e editores para a produção final. 
\begin{tabular}{l|l|l|l} 
12. Tecendo poemas & Produzir a escrita individual. & Produção final \\
$\begin{array}{l}\text { 13. Dando o toque final aos } \\
\text { poemas }\end{array}$ & Rever os poemas produzidos. & \\
\hline
\end{tabular}

- que novamente há coincidência entre a estruturas, tanto a SD como as oficinas finalizam seus processos com a produção final e o estabelecimento do texto que circulará entre os participantes.

Analisando, da mesma forma, os objetivos, destacados na capa de cada oficina (e condensados na tabela geral), é possível observar, embora as orientações não se limitassem aos traços formais (oficinas 2, 6, 7, 8, 9 e 12), que essa questão assumia uma função central ou definidora do poético na proposta.

Não há conteúdo sem forma e esta, no poema, irrompe e resulta em efeitos de sentido, desejáveis e esperados. Mas a exercitação acaba por limitar-se ao aspecto técnico da escrita poética. "A maneira como se vê o mundo", parâmetro apresentado no material das oficinas como questão central dos poemas, era vagamente contemplada nas orientações, levando a supor que dificilmente seria atingida apenas pela leitura dos textos poéticos ou da análise dos elementos formais. A poesia como resistência, como afirma Bosi, em $O$ ser e o tempo da poesia (1977), é um modo de ver o mundo e requer assumir um papel, um lugar para a prática social específica que a envolve. Talvez seja essa a fragilidade do material destinado à fase de preparação, embora não fosse aspecto ignorado pelos organizadores do prêmio. As oficinas 9 , 10 e 11 tinham como objetivo a busca de formas para expressar os sentimentos, a maneira como o poeta vê o mundo e como se vê no mundo que está a sua volta. "Ver o mundo de um modo poético", título da oficina 9, propunha aos alunos a busca de imagens que reconstruísse o mundo de acordo com essa visão. Havia a pressuposição de um olhar que daria forma à linguagem para se dizer, porém, muitas vezes, o que ocorre é a descoberta do mundo pelo dizer - questão não abordada na oficina.

Já a oficina 11, "Conhecendo-se emoções, sentimentos, tornando-se poeta”, reafirma, embora de forma deslocada, a questão dos sentimentos, do lirismo como cerne do poema. Esse tipo de oficina, chamado por Jolibert (1994) de Ateliês ${ }^{20}$ de impulsão afetiva e imaginária, tinham objetivos similares aos do Prêmio:

- ponham a trabalhar seu imaginário a partir de uma situação de impulsão que chamamos de situação trampolim, aproveitada ou provocada pelo professor;

\footnotetext{
${ }^{20}$ Os ateliês têm a duração e objetivos mais restritos, enquanto o canteiro (correspondente às sequências didáticas) "é um módulo de aprendizado para a produção de um tipo de texto particular". (JOLIBERT, 1994, p. 247)
} 
- experimentem seu poder de criação sobre a língua em produções originais de poemas. (JOLIBERT, 1994, p. 216)

A diferença entre ambos, no entanto, está no momento da aplicação. A oficina está dentro da sequência didática e o ateliê não.

Tais ateliês de impulsão afetiva e imaginária intervêm num momento do ano em que a prática das outras atividades poéticas (canteiros "poemas", sequências de análise das necessidades de diccção, encontros semanais) parece ser o suficiente para que as crianças estejam aptas a reinvestir as competências e os instrumentos construídos, isto é, para que elas possuam meios linguísticos (um conjunto de materiais) para traduzir suas emoções permitindo, assim, que o imaginário se expresse em criações individuais. (JOLIBERT, 1994, p. 217)

Mesmo sendo importante para os alunos, que se proponham oficinas com esse objetivo, a questão que cria um obstáculo seriam "as competências e os instrumentos construídos" pelos alunos nas oficinas anteriores, porque, na sequência didática do Prêmio, não houve tempo para o desenvolvimento dessas competências e tampouco para a definição de um gênero poético específico em momento anterior ao da aplicação da SD, o que ocorreu foi a busca de uma apresentação dos gêneros poéticos de forma global (tenha ela acontecido efetivamente ou não).

Segundo Jolibert, "um canteiro "poema" deve permitir que cada uma das crianças de uma turma aprenda a produzir um poema a partir de um texto de referência. Ou seja, encontrar as chaves linguísticas de acesso a um poema de referência para escrever um poema “à maneira de...”. (1994, p. 217) O trabalho a ser desenvolvido nas sequências didáticas deveria ser circunscrito a um poema de referência como ocorreu nas primeiras oficinas e, à medida que fossem apresentados, deviam se assemelhar por uma característica do gênero para que o aluno pudesse aos poucos desenvolvê-las, como o uso das rimas, o uso das imagens, uso do aspecto concreto do texto. Propor uma sequência didática com um número maior de elementos a ser trabalhado pressupõe uma atuação anterior nas turmas envolvidas e esse grau de homogeneização não poderia ser pressuposto no Brasil inteiro.

Assim, uma das hipóteses para que as impulsões afetivas e imaginárias não tivessem sido deixadas de lado, mas tivessem sido pouco aproveitadas talvez estivesse no fato de que a estrutura composicional seja um conjunto de elementos que carregam outras concepções do poético podendo fornecer caminhos para a ruptura com modelos anteriores. Os professores acabaram por começar de uma base tradicional de ensino, para depois avançar na recolocação do gênero em outro modo de percepção, aliando a essa estrutura as questões enunciativodiscursivas, que emergiram de forma explícita ou não, da leitura dos poemas apresentados nas oficinas e naqueles produzidos pelos alunos como veremos no capítulo 2 . 
O que fez o material oscilar foi o desenvolvimento de sensações e sentimentos pessoais, como no caso do acróstico (oficina 8) que deviam ser transferidos, espelhados, redesenhados ao lado do lugar onde o aluno vivia. Como a cidade ou o bairro onde ele mora foi apropriado por outros discursos, como os das disciplinas de Geografia e História, ou das conversas diárias sobre os problemas e belezas do cotidiano; nem sempre foram alcançados os alvos: o lirismo necessário; a apropriação dos recursos formais, a autoria. Assumir a voz no poema e nela fundar uma linguagem dificilmente poderia ser alcançado por meio desse tratamento do tema - que exigiria memória e repertório -, principalmente pela idade dos alunos (de $4^{\mathrm{a}}$ e $5^{\mathrm{a}}$ séries, atuais $5^{\mathrm{o}}$ e $6^{\circ}$ anos, entre 10 e 12 anos). $\mathrm{O}$ trabalho com o aspecto lírico, focalizado no emotivo como se apresentava na oficina, trazia o risco de conduzir o aluno ao engano de uma poética laudatória ou crítica. Essas não seriam as funções do poema, ainda que sejam efeitos de sentido possíveis de um texto poético, mas como escreveu Fernando Pessoa: “O poeta é um fingidor” (1980, p. 104) e, assim se definindo, o poeta está livre para ir além de suas experiências pessoais e alcançar outras, mesmo que as devolva de forma personalíssima.

Por outro lado, essa dificuldade talvez tenha sido compensada pela forma como se desenvolveu o processo: a insistência na produção logo no início (oficina 2) para que se operasse o processo de revisão do texto, a reflexão sobre sua estrutura, com aproximações e aprofundamentos cada vez mais verticalizados - a abordagem em espiral (SCHNEUWLY; DOLZ, 2004). Esse tipo de abordagem revelou uma atitude metodológica que supõe ser possível voltar ao gênero proposto várias vezes, porém a cada volta o aluno estaria em outro patamar, deslocamento com a finalidade de se aprofundar no gênero. Esses deslocamentos são observados também dentro das sequências didáticas, uma vez que, da produção inicial até a final, o aluno assume novas representações, e a agência, por meio do poema, leva-o a outros pressupostos e lugares de onde escreve e reescreverá.

Metodologicamente, também houve orientações operacionais relevantes, como colocar professor e alunos, primeiro em grupos, depois individualmente, para se apresentarem como autores ao lado dos poetas presentes no Kit Itaú de Criação de Textos - 2004. Essa estratégia sugeria questionar papéis e funções desse gênero, resultando numa abertura para além do espaço escolar e possibilitando a troca de visões de mundo nesse espaço. Ela permitia, ainda, evitar o aparente silenciamento operado em sala de aula, lugar onde tradicionalmente se coloca a voz dos textos em primeiro plano, deixando pouco espaço para 
opiniões dos participantes ou, ainda, para a exposição explícita da opinião do professor, seu posicionamento em relação ao mundo e ao gênero.

\subsection{Poesia tem a ver}

Um último aspecto a ser comentado a respeito do material são os poemas apresentados nas oficinas e na pequena antologia no fim do fascículo "Poetas da Escola". Eles tinham como função ser referência para o desenvolvimento da sequência didática, por essa razão entram na análise do material a fim de se estabelecer aspectos temáticos, composicionais e discursivos que possam ser retomados nos poemas dos alunos, objeto do capítulo 2.

O primeiro poema apresentado para os alunos tinha como tema a poesia - "Tudo a ver", de Elias José.

Essa temática em metalinguagem não apresenta o poema como objeto concreto. Há, nos versos do poema de Elias José, uma concepção de poética como fruição do mundo, uma espécie de empatia que se estabelece entre as "coisas" existentes e aquele que está vivo e se debruça sobre elas. A poesia é então uma chave para entender esses elementos. Oferecida ao leitor, ela ainda se apresenta na última estrofe como totalizante (A poesia / - é só abrir os olhos e ver - tem tudo a ver / com tudo).

Formalmente, há a presença de paralelismos em cada estrofe (a poesia / tem tudo a ver / Com...) que trazem ritmo para o poema em contraposição à abertura rítmica em decorrência da presença de versos polimétricos em todas as estrofes. Além da estrutura parelelística, os versos trazem os elementos do mundo na forma de sintagmas nominais. Há somente um adjetivo (veloz, verso 16). No lugar dessa classe de palavra, as locuções adjetivas estão modificando os núcleos desses sintagmas o que promove a caracterização por meio do substantivo. Como se os elementos do mundo o caracterizassem numa relação intrincada que, além da correspondência, aponta para novas relações, via campos semânticos trazidos por outros substantivos, na função de modificadores.

As imagens associadas à poesia são lugares-comuns dos textos poéticos com predomínio de um lirismo acentuado. A poesia, nessa concepção panteísta, está em tudo e à disposição, porém esse tudo (estrofe 4) é composto por dor, alegrias, sabores e música 
(estrofe 1); sorrisos, diálogos, lágrimas, olhos (estrofe 2); plumagem, vôo, canto, acrobacia, cores, ritmo, brilho, explosão (estrofe 3). São elementos legítimos da expressão pessoal, de uma percepção marcada pela apreciação que leva a uma euforia, não por outra razão a sequência de elementos é finalizada por "explosão".

Esses aspectos poderiam ser amenizados por um trabalho que indicasse caminhos múltiplos para cada um estabelecer do que o "seu" poema poderia tratar, porém com as questões postas na oficina, houve uma acentuação desses aspectos, principalmente pela personificação do poema, na questão: "Sobre o que ele fala?", como se fosse uma extensão do autor, visto que a pergunta seguinte é "por que o autor diz que poesia tem a ver com tudo?" Esse percurso de uma certa autonomia do objeto se efetiva na questão: “O que os poemas podem exprimir?" (PDE, p. 13-14)

Essa visão parece ser contraditória àquela indicada para ser trabalhada com os alunos: "Existe em nossa cultura uma crença muito arraigada de que a função da peosia é cantar amores ou exaltar o belo. É importante ajudar seus alunos a ultrapassar essa crença e compreender que, na verdade, a poesia traduz em palavras a maneira como o poeta olha o mundo.” (PDE, p. 13). Se os professores buscarem esse caminho, não podem ir pela expressão do objeto, mas precisam seguir por essa expressão do sujeito. Onde está ele nas questões que se referem ao texto?

Em seguida, na oficina 5, "Ouvindo, lendo e conhecendo mais de poesia", há a sugestão da leitura dos poemas para que os alunos vejam "como esses poetas deixam de lado o lugar-comum para fazer aquilo a que todo poeta se propõe: pegar na mão dos leitores e encantá-los, trazendo inspiração e despertando emoções." (PDE, p. 24). Os poemas elencados são "Sertão", de Ascenso Ferreira (PE); "Coisas do reino da minha cidade", Cora Coralina (GO); "Mar azul”, Ferreira Gullar (MA); "Episódio sinistro de Virgulino Ferreira”, Carlos Pena Filho (PE); "Infância", Carlos Drummond de Andrade (MG); "Na rua Mario de Andrade”, Manoel de Barros (MT); “Canção do Exílio", Gonçalves Dias (MA); "Na minha terra", Álvares de Azevedo (SP); "Pátria minha", Vinicius de Moraes (RJ). Após os nomes dos poetas, aparecem os estados onde nasceram. Essa informação talvez assuma a função de indicar quão abrangente é a seleção e como ela se refere a inúmeros lugares reforçando o caráter modelar dos poemas para os alunos. 
O comentário sobre o fazer dos poetas (sair do "lugar-comum") novamente remete a uma concepção do texto poético em que a originalidade e a novidade são elementos centrais. Para alunos, cujo repertório, em geral, não tem a abrangência requerida para esses deslocamentos uma vez que as imagens desgastadas nem sempre são reconhecidas como tal e muitas vezes constituem o repertório deles, essa meta pode não ser compreendida como os organizadores planejaram. Aliada a essa solicitação, a necessidade de inspirar e despertar emoções pode levar à busca de elementos que mais facilmente levem a esses sentimentos ou posturas.

Cada um dos poemas evidencia, em sua estrutura, variadas escolhas de ponto de vista e de aspectos formais importantes para a construção do tema, mas o tipo de organização de texto que se destaca em virtude, algumas vezes, do recorte efetuado em alguns poemas, provavelmente por causa da extensão desses textos ("Sertão", "Coisas do reino da minha cidade", "Episódio sinistro de Virgulino Ferreira", "Na rua Mario de Andrade") é o descritivo. O tipo descritivo, nesse caso, de caráter subjetivo, funde as informações sobre o local a "uma expressão de sentimentos, afetividade e estados psicológicos daquele que diz." (TRAVAGLIA, 2007, p. 47) Trata-se de uma estratégia textual adequada ao tema embora não configure, de forma imediata, nenhum gênero poético específico. Assim essa repetição pode criar a expectativa no aluno de que esse tipo deve ser característico do gênero a ser produzido - o que não seria verdadeiro, pois há várias outras características da superfície linguística do texto que poderiam ser adotadas na produção do poema.

Travaglia conceitua as características da superfície linguística do texto como:

a que Bakhtin (1992) chamou de estilo, são elementos composicionais de formulação da sequência linguística, do que muitos chamam de superfície linguística. Essas características podem referir-se a qualquer plano da língua (fonológico, morfológico, sintático, semântico, pragmático) ou nível (lexical, frasal, textual).

É preciso que fique claro que a caracterização por meio desse parâmetro não se refere pura e simplesmente ao recurso linguístico utilizado, mas também a sua relação com as propriedades da categoria. Estamos chamando de propriedades, por exemplo, as perspectivas definidoras dos tipos, a instauração de locutor e alocutário enquanto enunciadores (produtores de uma enunciação contextualizada e condicionada pelos contextos de situação e sócio-histórico-ideológico, por objetivos de interação, etc., enfim, considerando-se as condições de produção), os objetivos/funções das categorias de texto, os objetivos/funções definidores de gêneros, etc. (2007, p. 62-63)

Por serem características que instauram também as relações determinadas pelas condições de produção, apresentam-se, nos parágrafos seguintes, essas características em cada um dos poemas da antologia. 
Em "Sertão", o trabalho sonoro, nas falas das personagens do sertão (os vaqueiros) e nos sons de artefatos do local e da atividade do vaqueiro (chocalhos - "blém... blém....blém", guizos - “dlin... dlin...dlin...", sinos da igreja - "bão... bão... bão”), constrói o local pela impressão auditiva causada no observador, que as avalia ao caracterizar os elementos do poema nos adjetivos em negrito: "os chocalhos dos tristes bodes patriarcais"; "os guizos fininhos das ovelhinhas ternas" e o "sino da igreja velha" - numa espécie de transposição da sociedade nos "atores" presentes no poema.

Em "Coisas do reino da minha cidade", o elemento organizador do poema é o "eu" estabelecido no primeiro verso pelas formas verbais "olho e vejo". A partir desse ponto de vista, surgem as mangueiras que receberão todas as qualidades que caracterizam os "reinos de Goiás", como a poetisa afirma no verso final ("Estas coisas nos reinos de Goiás”). Esse recorte como o anterior remetem ao "eu" - como responsável pelos pontos de vista que permitem a construção do local.

Em "Episódio sinistro de Virgulino Ferreira", os elementos apontados como válidos nos critérios de avaliação, aparecem condensados: há o local com seus objetos e personagens pitorescos. Dentre eles, o cego e sua viola parecem resumir esse caráter por trazerem pela palavra o futuro e o nó central da narrativa do poema, que não se encontra no excerto escolhido (há somente o trecho inicial).

Em "Mar azul", a tentativa de tornar os movimentos do mar reais nos versos mostra, pelo movimento das ondas marcado na extensão dos versos, a revelação dos objetos que, aos poucos, se destacam no horizonte. O quadro final supera as ondas, chega ao ar, lugar do "azul". Esse adjetivo passa então a ser o substantivo que engloba todo o recorte do mundo.

Em "Infância", a subjetividade como ponto central da exploração do espaço, neste caso, imbricado com o tempo (a infância), volta como elemento central para a organização temática. Os pronomes possessivos permitem a expansão desse eu por todo o espaço do passado. É a apropriação do espaço pela visão pessoal - a fazenda da infância tem os limites da consciência daquele menino no corpo do homem - dois momentos enunciativos que se confundem e delineiam a vida do eu.

Em "Na rua Mário de Andrade", o uso de elementos intertextuais (como "é preciso flanar" em que se encontram Mario e Baudelaire; ou a citação de versos do poema de Bandeira, "A morte absoluta" e a menção de Macunaíma), aliado às marcas da oralidade (“vou ir com Macunaíma”) tão presentes na gramatiquinha de Mário de Andrade, surge como 
uma forma de diálogo e talvez não seja possível para a faixa etária dos alunos um trabalho em que o poema seja um exemplo para se escrever sobre o espaço. Há aqui uma reflexão sobre como os poetas pensavam a "eternidade" que a escritura proporciona e uma homenagem a Mario e aos poetas formadores para a poética de Manoel de Barros; o que ultrapassa a apropriação do espaço pelo eu, uma vez que o espaço se amplia para o espaço da poética do autor.

Finalmente em "Canção do Exílio", tem-se a apropriação do espaço pela representação do que esse lugar promove numa linguagem utópica que o exílio elabora no eu pela impossibilidade momentânea de se deslocar para lá. Como no poema de Elias José, os substantivos assumem a função de modificadores pela adesão que cada objeto sofre pela ação verbal - a função dos modificadores é indicada pelo verbo "ter", significando a posse, e os advérbios de intensidade ("mais flores, mais bosques, mais vida, mais amores") e de comparação (“como lá”).

Há realmente uma diversidade de ritmos, tipos de versos, estrofes, concepções estéticas na seleção efetuada; o que favorece a escolha para a elaboração de uma expressão pessoal, porém o truncamento dos poemas rompe com a noção de unidade que é essencial para os gêneros poéticos, pois na estrutura organizacional desses gêneros a noção de tensão na forma, aliada à de completude é essencial. Nada pode ser suprimido ou alterado uma vez que as modificações provocariam a perda da identidade do texto ou o deslocamento das redes semânticas responsáveis ao lado do estilo, pela constituição do tema.

Há ainda outro poema, na oficina 6, "Duas dúzias de coisinhas à-toa que deixam a gente feliz”, de Otávio Roth. Esse texto tem como a função

de que cada um deles (alunos) pense e conte para os demais coisas simples ("coisinhas à-toa") que o deixem feliz. Talvez alguns mencionem coisas grandes, importantes, como a paz no mundo ou a preservação do meio-ambiente. Mas insista em que a idéia é falar de pequenas coisas do dia-a-dia. (PDE, p. 26)

O objetivo da oficina se constitui como tentativa de equilibrar as tensões surgidas de todas as orientações para os professores uma vez que trabalhar com os poetas consagrados (como são qualificados na oficina 5) pode provocar uma representação contrária àquela pretendida, por representações residuais vindas da maneira como os gêneros poéticos foram apresentados na escola. 
Dentre os agrupamentos de representações circulantes, é possível distinguir dois. Representações do poema como texto criptografado ou hermético ou algo que está longe do horizonte do homem comum estiveram presentes durante vários momentos da história do texto poético provavelmente pela presença do gênero em rituais, em rodas de história ao redor da fogueira em que o caráter figurativo no segundo caso e o caráter sagrado no primeiro podem ter conferido a impressão de que era preciso uma competência para se fazer e para entender de forma adequada o poema. Outra representação de presença acentuada a partir da segunda metade do século passado foi a do poema como algo difícil de ser interpretado, pelo caráter subjetivo das aproximações mediadas pela leitura, que resulta também em afastamento e desvalorização do gênero. ${ }^{21}$.

O poema de Otávio Roth, contrariamente a essas representações, apresenta gatilhos para epifanias provenientes do dia-a-dia, sublinhadas pelo diminutivo "coisinhas" e pela locução adjetival "à-toa”. Ao lado desses aspectos que parecem minimizar o volume de coisas apresentadas (“duas dúzias”, quantificação presente no título, e graficamente, um bloco fechado de sintagmas que se sucedem conectados pela vírgula, cf. anexo 2), há a oração subordinada adjetiva restritiva (que deixam a gente feliz), reiterando o peso (presente no título) que essas coisas passam a ter na vida de cada um; afinal a felicidade é um sentimento complexo. Por essa razão, a leitura do poema ou a recolha dos elementos que façam os alunos felizes, que rimem, não parece ser o bastante, além do insubstituível diálogo sobre esses elementos esclarecendo o recorte valorativo de cada um para a constituição da (ou de uma) felicidade, é necessário que, para a criação de um texto próprio, o aluno esteja atento, graças a intervenção do professor, à forma como o poeta insere essas "coisinhas" - trata-se de sintagmas nominais sem oração interna ("passarinho na janela"; "pijama de flanela", "brigadeiro na panela"; "cheirinho de mata molhada", "pão quentinho de manhã" etc.); sintagmas nominais com orações internas, reduzidas ou não ("gato andando no telhado"; "papagaio que conversa", "herói que fuma cachimbo", etc.); sintagmas verbais ("tirar a sorte no osso", "jogar pedrinha no poço”, descer pelo corrimão”) e uma oração nominalizada (“eu te amo e vice-versa"). Todas essas formas têm um caráter estático, em que as situações parecem fotografadas pela memória, prontas para estimularem o leitor.

\footnotetext{
${ }^{21}$ Para a primeira representação de poema, conferir as representações de poesia em poetas consagrados em TEZZA, 2003; e na concepção do poético em PAZ, 1996; já para a segunda concepção, MICHELETTI, 2000.
} 
Além do recorte efetuado pelo enunciador no poema, valorativo e representativo de um lugar discursivo, tem-se de volta o poema como estímulo para outras atividades, mesmo que seja para a produção de textos poéticos.

O poema, pela tensão que imprime à forma e à construção de sentidos, parece dominar a fase de sensibilização para a produção de outros gêneros. Assim aos alunos pode parecer que não é condição buscar essa arquitetura aliada a uma posição, basta que a sensibilidade tenha sido "tocada" de alguma forma.

Depois da sensibilização para o cotidiano, a finalidade da oficina 7 é o trabalho com os aspectos sonoros (rima, aliteração e assonância). Novamente, a preocupação com a forma poderia levar a uma exercitação sem conteúdo, valorizando o aspecto lúdico sem aproveitá-lo na representação do local. O que atenua a dispersão causada pelo exercício com essas figuras de linguagem é o gênero poético escolhido, a quadra, que encontra adesão junto aos alunos pelo caráter popular, pela presença das rimas e da métrica, redondilha maior ${ }^{22}$ e a orientação:

\begin{abstract}
Muitas vezes os alunos ficam tão preocupados em encontrar palavras que rimam que se esquecem de verificar se o verso construído trans mite ao leitor uma idéia, sentimentos ou sensação. Leia e analise junto com eles os poemas do Apêndice e mostre como os poetas, ao usarem o recurso da rima, são cuidadosos na escolha das palavras. Os versos e as estrofes não são construídos apenas com palavras que rimam entre si; eles devem articular-se como um conjunto que produz sentido. (PDE, p. 30).
\end{abstract}

Sentir-se à vontade com determinado gênero poético, por fazer parte do repertório via cantigas de roda, parlendas e outros, promove no aluno uma adesão maior e maior desenvoltura na construção do seu próprio texto. Cabe então ao professor reforçar certos caminhos dentro das oficinas para que os alunos possam desenvolver seus poemas sem a dispersão causada pela experimentação de inúmeras formas simultaneamente.

A dispersão presente no fascículo "Poetas da Escola" pode ser entendida como semelhante àquela que ocorre com a estruturação do livro didático (BARBOSA, 2001), em que a necessidade de abordar os vários gêneros ou as formas literárias marcadas como relevantes pela tradição de elaboração dos conteúdos programáticos, promove no material a não marcação de um foco, em abordagens múltiplas. Há vários elementos discursivos e

\footnotetext{
${ }^{22}$ A redondilha maior é um dos versos mais comuns na poesia popular brasileira, elemento central da métrica da maioria das cantigas de roda, como "batatinha quando nasce" ou "atirei o pau no gato" ou vários poemas de cordel, bem como alguns poemas românticos mais populares, como "Canção do exílio" e "Meus oito anos", respectivamente de Gonçalves Dias e Casemiro de Abreu. (GOLDSTEIN, 2007, p.36-37)
} 
composicionais pertinentes que, pela presença simultânea nas oficinas, pode levar à ausência de reconhecimento de um percurso.

O que dificulta a assunção desse percurso, muitas vezes, é o que Padilha (2005) aponta como silenciamento, uma vez que esses materiais didáticos são permeados por filtros apagando a posição autoral de cada um dos textos escolhidos para o livro didático (poemas, em nosso caso) ao instaurarem outra posição, a do autor do livro que contém esses textos. Dessa forma,

\begin{abstract}
Pode-se naturalmente argumentar que tomar os textos poéticos nos livros didáticos como objetos estéticos, em seu todo, não é tarefa que compete ao autor do livro didático. Contudo, percebemos que sempre haverá uma posição autoral assumida, de um sujeito-autor que apresenta valorativamente os textos que compõem suas obras didáticas, o que significa que, em algum momento, o texto poético é sim tomado como um objeto estético sobre o qual se lança um determinado olhar. (PADILHA, 2005, p. 49)
\end{abstract}

Os professores, ao utilizarem um material didático já pronto, têm uma tarefa dupla: identificar e compreender o que o(s) autor(es) pretendiam com as escolhas feitas e o que os poetas haviam construído para os seus textos. A valoração, muitas vezes, diversa para cada um dos casos, será redefinida pelo professor. Há, portanto, muitas instâncias até chegarmos ao aluno e nele, outra valoração se processa. Essas inúmeras retículas sobre um único texto se multiplicando pela proximidade criada na antologia ou na obra didática foram minimizadas no fascículo "Poetas da Escola", mas não estão fora da preocupação que se deve ter e que, nas antologias, é contornado (e talvez, em alguns casos, superado) pelo uso do prefácio (de caráter ensaístico), de notas explicativas para o professor e para o aluno, (em volumes separados) - um diálogo em duas etapas: a primeira entre o organizador da antologia e as condições de leitura em sala de aula; a segunda entre o organizador da antologia e o professor.

Essas questões aparecem também no material do Prêmio, pois como se afirmou anteriormente: o fascículo deveria ser apreendido pelo professor, transformado em algo seu e trabalhado com os alunos. Muitas vezes, como essa relação para a apreensão do material ocorre em sala de aula, uma vez que não se trata de processo individual - o diálogo com os alunos estabelece caminhos que não podem ser determinados a priori. Boa parte do sucesso das oficinas (os ateliês como Jolibert, 1994, as nomeia) vem do planejamento, que pressupõe uma consciência fina das habilidades e competências a serem trabalhadas. Inclusive no e pelo professor, uma vez que o trabalho bem sucedido resulta da apropriação pelo professor do 
processo com o qual trabalha. O professor estaria preparado para entender o processo de criação poética ou seria mais um conteúdo a ser trabalhado com os alunos? Em relatos de experiências na França, Cosem (1980) observa que o poema não conseguia um espaço, embora estivesse no planejamento do professor, porque o docente não gostava de poesia nem conseguia se envolver com o poema.

As reflexões desenvolvidas até aqui indicam que a formação do professor ficou em segundo plano, na edição do prêmio "Escrevendo o futuro" de 2004. Esse seria um dado a ser considerado e revisto pelos organizadores.

Passamos a seguir à análise das produções poéticas dos alunos finalistas do pólo São Paulo, dessa mesma edição do prêmio. A meta é buscar indícios da participação discente no processo e do modo como ela aconteceu, para que seja possível "unir as pontas" do processo, com a finalidade de avaliar o Kit de forma mais precisa. 


\section{Capítulo 2}

\section{E todos eles rimavam...}

Neste capítulo, são analisados os poemas dos alunos do Pólo São Paulo, segundo os critérios de avaliação apresentados no material do Prêmio "Escrevendo o Futuro"; as concepções de ensino do gênero poético e a questão da autoria no gênero. 


\section{Poesia}

Gastei uma hora pensando em um verso

Que a pena não quer escrever.

No entanto ele está cá dentro

Inquieto, vivo.

Ele está cá dentro

E não quer sair

Mas a poesia deste momento

Inunda minha vida inteira

(ANDRADE, 2001) 
O que esperar da produção textual no gênero poético na escola? E se a recepção dessa produção estiver parcialmente fora das paredes da escola?

Num concurso, o resultado final se impõe como a única instância a ser levada em conta. Essa tomada de atitude se assemelha àquela do leitor que considera esse encontro como ponto de partida e então passa a usufruir do que o poeta propôs nas páginas do livro. Com esse objeto concreto a sua frente, o leitor coloca em cena os critérios sistematizados, ao longo dos $\operatorname{anos}^{23}$, a partir da experiência com o gênero poético. Ele pode começar pela identificação da forma (a regularidade ou a ausência dela) ao observar o texto como mancha na página. A identificação imprime uma tomada de decisão na leitura. Lugares para pausas e retomadas. Assim um soneto se destaca de um epigrama, que, por sua vez, é breve, se comparado a um cordel serpenteando por várias páginas. Essas impressões, porém, não são, em geral, incorporadas à percepção de modo consciente. São comportamentos, muitas vezes automatizados uma vez que fazem parte da superestrutura ${ }^{24}$ e são trazidas para o ato de ler como bases que, ao lado da pontuação, métrica, rimas (caso existam) e outras estruturas que fazem parte da composição textual, guiam esse leitor no poema.

Embora façam parte da estrutura composicional, certas estruturas como os versos, a distribuição das estrofes, o número em que elas se apresentam passam, depois de certo tempo, a fazer parte dos esquemas cognitivos, que foram estabelecidos discursivamente num dado momento e são "naturalizados" em momento posterior na representação do objeto "poema". Essa ideia de naturalização de certos esquemas cognitivos de percepção e apreeensão das informações pode ser experimentada pelo modo como as crianças, olhando um texto em versos, indicam ser um poema antes mesmo de lê-lo. Evidentemente essa primeira percepção necessita de outros elementos para sua confirmação e o grau de maturidade do leitor permitirá ou não que o lapso no processamento de um número maior de informações seja cada vez menor, pela velocidade com a qual se processam os dados presentes no texto.

No Prêmio "Escrevendo o futuro", essa atitude habitual, que faz parte das trocas mediadas pela leitura no nosso mundo letrado fora da escola, foi substituída por duas outras. A primeira identificada, como parte da leitura de textos feita em concursos, e a segunda, a da esfera escolar, que tem, como critério norteador na abordagem presente nos fascículos, o

\footnotetext{
${ }^{23}$ Se for um ou muitos critérios, os resultados serão evidentemente diversos na qualidade da leitura, mas mesmo sendo poucos, haverá interferência na atitude responsiva que o leitor mantém com o texto, que envolve o conhecimento sistematizado do objeto a sua frente.

${ }^{24}$ Para o conceito de superestrutura cf. KOCH, TRAVAGLIA, 2008.
} 
produto e o processo de produção. Num primeiro momento, a comissão da cidade (formada pelos membros da escola e da comunidade local) havia escolhido o texto a ser enviado para o CENPEC a partir dos poemas em sua dimensão concreta, apresentada na folha de papel, segundo critérios definidos a priori ${ }^{25}$ no Kit, como ocorreria em qualquer concurso. Num segundo momento, a avaliação volta à esfera escolar, pois o processo (que permanece ainda marcado no texto) passou a ser a preocupação dos avaliadores. A decisão pelos poemas não se deu apenas pela leitura do objeto na folha de papel e mais a construção de imagens e percepções decorrentes dessa leitura. Para a seleção dos finalistas, foi feita também a verificação do percurso, uma vez que textos poéticos que parecessem "editados" por um adulto foram objeto de averiguação - o intuito, no entanto, não era eliminar aquele que suscitasse essa desconfiança, uma vez que os critérios agregados aos apresentados no fascículo resultaram na instituição de oficinas e atividades presenciais para os finalistas de modo que a comissão avaliadora do CENPEC pudesse mensurar a produção do aluno como autêntica (mesmo que com algumas marcas de intervenção, como se verá depois nas análises), ou seja, resultado de um processo instaurado pela sequência didática nos trabalhos em sala de aula e não, como parceria com outros agentes, tais como professor, pais, e afins. ${ }^{26}$

Dessa forma, embora o processo de produção de um texto não possa ser recobrado apenas pelas orientações fornecidas - os parâmetros gerais para essa ação -, pois, desde o início da pesquisa, era fato que o material que formava o corpus (Kit Itaú de Criação de Texto, Relatos de duas professoras ${ }^{27}$ e os poemas finalistas do Pólo São Paulo) não permitiria a leitura de todo o percurso previsto no projeto, estabeleceu-se que a análise do material seria acrescida da leitura analítica dos poemas, recuperando, nos textos, os critérios e objetivos instaurados em cada etapa de elaboração do corpus.

O que se apresentava, nessa fase, para a análise da produção eram textos que, em sua materialidade, possibilitariam que se recobrassem a estrutura composicional, o estilo e as questões discursivas, fornecendo elementos para uma reflexão sobre os aspectos negativos e positivos da proposta e sua operacionalização.

\footnotetext{
${ }^{25}$ Cf. p. 32 e 33.

${ }^{26}$ As atividades dessa fase de avaliação não são objeto desse trabalho, porque representam uma fase posterior à produção e estabelecimento do texto como "obra prima", uma indagação de outra ordem de interesses que ultrapassam a questão da produção do poema.

${ }^{27} \mathrm{Na}$ primeira página da Oficina 1 , há um box, "dica para o professor", cujo texto ressalta a importância do registro como "um dos mais importantes instrumentos de aprendizagem e aperfeiçoamento da prática docente", mesmo com esse estímulo, poucos professores entregaram seu registro.
} 
As primeiras leituras não foram feitas somente com os poemas do Pólo São Paulo, mas se estenderam a todos os poemas produzidos naquela edição do Prêmio. Desses contatos iniciais com os textos, tendo como guia os parâmetros apresentados pelos critérios de avaliação do caderno de orientações iniciais "Cá entre nós"28, foi possível perceber uma questão derivada: a representação do "eu" relacionada à representação do lugar. Os apagamentos ou as redundâncias; a ausência de voz ou a altissonante voz do "eu" se apresentavam como indícios para avaliar de forma global as produções, envolvendo não só o reconhecimento das estruturas formais e de conteúdo, mas ainda a postura do poeta que precisa firmar sua posição e trazer sua voz para o texto, relacionando-se com as outras vozes que envolvem o tema, porque "o escritor encontra seu tema sempre já envolto em uma aura heteroglóssica constituída pela consciência social e vai, basicamente, se orientar de forma responsiva nessa aura.” (FARACO, 2005, p. 49).

Analisar a relação dessas vozes como outro elemento para a corporificação do tema tornou significativa a apresentação dos poemas tal como circularam nos cadernos dos finalistas. Como era exigência do Prêmio, os textos eram manuscritos em um formulário específico em que apareciam a identificação do aluno, a idade e a série em que estava, o nome da escola e o do professor. Por essa razão, os poemas, neste capítulo, serão apresentados na forma escaneada, pela importância que a letra de cada aluno assume, principalmente se pensarmos no ethos, aqui entendido como "imagem de si que o locutor constrói em seu discurso para exercer uma influência sobre seu alocutário" (CHARADEAU; MAINGUENEAU, 2004, p. 220). A letra cursiva seria um dos elementos da corporalidade do ethos. Nesse caso, equivaleria ao vestuário e à parte do tom de voz e dos gestos que o locutor imprime ao falar e que carece de um paralelo no texto escrito. Essa aproximação do universo da escrita e da oralidade também é possível se se assumir que há, nesses poemas, um forte traço da oralidade principalmente na elaboração do esquema rítmico e no estabelecimento dos esquemas prosódicos dos versos. Porém, como a imagem xerocopiada pode apresentar problemas de definição, o poema será transcrito antes da análise, acompanhado pelos dados que identificam apenas a série e o sexo do aluno. ${ }^{29}$

\footnotetext{
28 1) pertinência ao tema proposto; 2) observação dos elementos da poesia; 3) busca das informações sobre o tema; 4) originalidade.

${ }^{29}$ Nesse trabalho, não foi feita uma análise sociolinguística que pudesse utilizar o critério gênero como definidor de uma forma de escrever, mas considerando esse dado como indicador de formas de constituição do ethos.
} 


\subsection{Registro, terra querida}

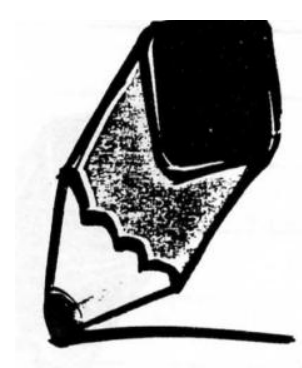

$P \quad R \quad E M I O$ $=E C O V A O O$

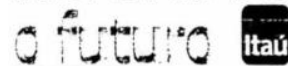

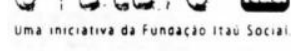
Sua escoia concorre. ¿ o brasî ganna.

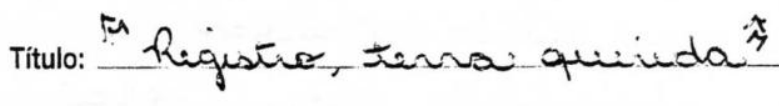

heigistre cielade amiga

Ma mineva viala, tena quiliaia?

Pássares antam na lonanciva

is margens de Ris Rileiva.

Pava tads es lades aum dive.

Vije verdis mentes,

Pidas dai mata sitianrticai

Batijadri ion sulas fontes.

O Sucpar ondir veve

Iim gente diferente,

ginte darinin mesomer,

Egenti da tina do sol rareinta.

Conciarros registrande e suvo

Lomes utí a capital de ví

mas quim gosta mesmo de imprar

Juader or qui privirav,

'É aqui qui voi unoentraw.

Polviçate su thes digo

Comecamos a recitlaw o lines

I pover daqui is espertir

Estal semper fanfondor squié inte. 


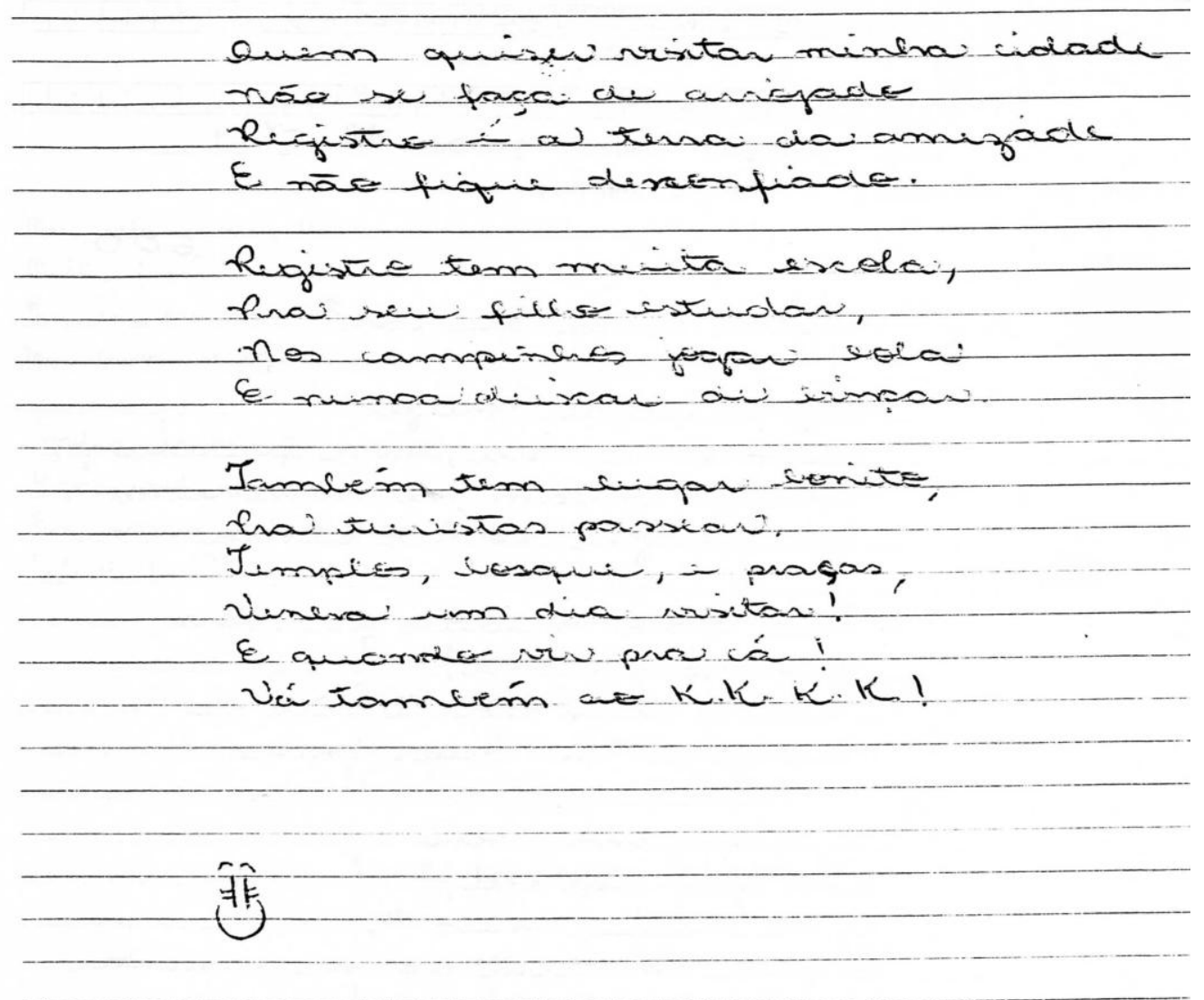

\begin{tabular}{|l|l|}
\hline${ }^{30}$ Série & $5^{\mathrm{a}}$ \\
\hline Sexo & Feminino \\
\hline
\end{tabular}

\begin{tabular}{|c|c|c|c|}
\hline & "Registro, terra querida" & 18 & Poluição eu lhes digo \\
\hline & & 19 & Começamos a reciclar o lixo \\
\hline 1 & Registro cidade amiga & 20 & O povo daqui é esperto \\
\hline 2 & Na minha vida, terra querida & 21 & Esta sempre fazendo o que é certo. \\
\hline 3 & Pássaros cantam na bananeira & & \\
\hline 4 & Às margens do Rio Ribeira. & 22 & Quem quizer visitar minha cidade \\
\hline 5 & Porn todes os lodes aue olho & 23 & Não se faça de arrojado \\
\hline 3 & Para todos os lados que olho, & 24 & Registro e a terra da amizade \\
\hline 0 & Vejo verdes montes, & 25 & E não fique desconfiado. \\
\hline 7 & Pérolas da mata Atlântica & & \\
\hline 8 & Batizada com belas fontes. & 26 & Registro tem muita escola, \\
\hline & & 27 & Pra seu filho estudar, \\
\hline 9 & O lugar onde vivo & 28 & Nos campinhos jogar bola \\
\hline 10 & Tem gente diferente, & 29 & E nunca deixar de brincar. \\
\hline 11 & Gente daqui mesmo & & \\
\hline 12 & E gente da terra do sol nascente. & 30 & Também tem lugar bonito, \\
\hline & & 31 & Pra turistas passear, \\
\hline 13 & Começamos registrando o ouro & 32 & Templos, bosque, e praças, \\
\hline 14 & Fomos até a capital do chá & 33 & Venha um dia visitar! \\
\hline 15 & Mas quem gosta mesmo de comprar & 34 & E quando vir pra cá! \\
\hline 16 & Tudo o que precisar, & 35 & Vá também ao K.K.K.K! \\
\hline 17 & É aqui que vai encontrar. & & \\
\hline
\end{tabular}

\footnotetext{
${ }^{30}$ Omitiu-se o nome deixando apenas dados que indiciam elementos significativos para a análise.
} 


\section{O poema atende aos critérios pertinência ao tema proposto e busca de informações}

sobre o tema por indicar a origem da cidade, a história ("começamos registrando o ouro / fomos até a capital do chá"), os atores envolvidos ("Tem gente diferente / Gente daqui mesmo / E gente da terra do sol nascente") e os elementos da cultura local (K.K.K.K. ${ }^{31}$ ).

Quanto à observação dos elementos da poesia, o que se destaca é o uso da rima. Embora não exista um tipo predominante no poema, são criadas regularidades nas estrofes, constituindo-se como um dos pontos de apoio para a representação do que um texto dos gêneros poéticos teria. A organização dessas pequenas "ilhas" que apresentam unidade interna se assemelha à estruturação dos parágrafos dos gêneros prosaicos de cunho argumentativo, uma vez que também nesses gêneros (como a redação escolar) cada parágrafo apresenta unidade interna, ligando-se aos outros por coesão referencial ou coesão sequencial, em sequenciação frástica ou parafrástica ${ }^{32}$ (cf. KOCH, 2003).

Nas $1^{\mathrm{a}}$ e $5^{\mathrm{a}}$ estrofes, quanto à disposição das rimas, há a presença de emparelhadas ${ }^{33}$, e, quanto à natureza, há consoantes ("bananeira" e "Ribeira"; "esperto" e "certo", dois últimos versos das $1^{a}$ e $5^{\text {a }}$ estrofes) e símil-rimas ("amiga" e "querida"; "digo" e "lixo", dois primeiros versos das $1^{\mathrm{a}}$ e $5^{\mathrm{a}}$ estrofes). As consoantes são rimas mais conhecidas e presentes em poemas com os quais os alunos têm familiaridade. Já as símil-rimas, em que as vogais tônica e pós-tônica coincidem sem que essa coincidência seja total como nas rimas consoantes, são aproximações e indicam a percepção da aluna quanto ao trabalho sonoro no poema.

\begin{tabular}{|c|c|}
\hline $1^{\mathrm{a}}$ & $5^{a}$ \\
\hline Registro cidade amiga & Poluição eu lhes digo \\
\hline $\mathrm{Na}$ minha vida, terra querida & Começamos a reciclar o lixo \\
\hline Pássaros cantam na bananeira & O povo daqui é esperto \\
\hline Às margens do Rio Ribeira. & Esta sempre fazendo o que é certo. \\
\hline
\end{tabular}

\footnotetext{
${ }^{31}$ KKKK é a abreviação, em japonês, de Companhia Ultramarina de Desenvolvimento que fornecia apoio para os imigrantes japoneses que vinham para o Vale do Ribeira. Hoje, o prédio da KKKK, um dos marcos da cidade, faz parte do patrimônio histórico da cidade tombado pelo CONDEPHAT, em 1987. Fonte: http://www.registro.sp.gov.br/kkkk.asp, acesso em 06-06-2008; http://www.plugadonovale.com.br/cidades/registro/default.asp?id=fuijbjq8e4vlbp7d3cn731 xn2gq8nu72x2qddp2 nw2fqfk49a4bcbcxov63kcmhhnx7o7vpb3c8ed52gs5h7ohseybh4qgs6tmgw , acesso em 06-06-2008.

${ }^{32}$ Para os conceitos de coesão referencial, sequencial em sequenciação frástica ou parafrástica, cf. Koch, 2003.

33 Os critérios de classficação das rimas são relevantes para se observar o grau de elaboração e o estabelecimento da unidade do poema mesmo que os alunos não tenham visto todos os tipos nem o valor que cada um desses tipos adquire ao longo da história literária. Sobre a classificação, cf. MELLO, 2001. Sobre a elaboração da estrutura em rede no poema, cf. GOLDSTEIN, 2008.
} 
$\operatorname{Nas} 2^{\mathrm{a}}, 3^{\mathrm{a}}, 6^{\mathrm{a}}$ e $7^{\mathrm{a}}$ estrofes, as rimas são alternadas, de duas formas. Na $2^{\mathrm{a}}$ e $3^{\mathrm{a}}$, somente os versos 2 e 4 das estrofes rimam ("montes" e "fontes"), ao passo que nas $6^{\text {a }}$ e $7^{\text {a }}$ estrofes, os versos 1 e 3 rimam ("cidade" e "amizade"; "escola" e "bola") e os versos 2 e 4 também ("arrojado" e "desconfiado"; "estudar" e "brincar").

\begin{tabular}{|c|c|}
\hline $2^{\mathrm{a}}$ & $3^{\mathrm{a}}$ \\
\hline Para todos os lados que olho, & O lugar onde vivo \\
Vejo verdes montes, & Tem gente diferente, \\
Pérolas da mata Atlântica & Gente daqui mesmo \\
Batizada com belas fontes. & E gente da terra do sol nascente. \\
\hline
\end{tabular}

\begin{tabular}{|l|l|}
\hline \multicolumn{1}{|c|}{$6^{\mathrm{a}}$} & \multicolumn{1}{c|}{$7^{\mathrm{a}}$} \\
\hline Quem quizer visitar minha cidade & Registro tem muita escola, \\
Não se faça de arrojado & Pra seu filho estudar, \\
Registro é a terra da amizade & Nos campinhos jogar bola \\
E não fique desconfiado. & E nunca deixar de brincar. \\
\hline
\end{tabular}

Há ainda duas estrofes, em que aparecem somente um tipo de rima (quase todas as palavras, verbos da $1^{\text {a }}$ conjugação). Existe, nesse caso, um trabalho sonoro menos elaborado, mas que mantém, como nas outras estrofes, percepções da rede sonora instituída na caracterização dos gêneros em questão. O processo de aproximação, que ocorre ao se justapor "chá", "precisar", “encontrar", "comprar" (4 estrofe) e "passear", "visitar", “cá", "K.K.K.K” ( $8^{\mathrm{a}}$ estrofe) pela rima, sugere o reconhecimento que a aluna fez do apagamento que existe na língua oral do "r" em final de sílaba. Pode parecer um equívoco, mas se trata de um raciocínio adequado a quem busca o efeito sonoro. A flutuação entre escolhas na língua oral e na língua escrita não se vinculam diretamente à questão de aprender os gêneros poéticos. Trata-se da aprendizagem da escrita em geral e da caracterização das variantes da língua, tarefa para a qual os gêneros poéticos podem contribuir.

\begin{tabular}{|c|c|}
\hline $4^{a}$ & $8^{a}$ \\
\hline $\begin{array}{l}\text { Começamos registrando o ouro } \\
\text { Fomos até a capital do chá } \\
\text { Mas quem gosta mesmo de comprar } \\
\text { Tudo o que precisar, } \\
\text { É aqui que vai encontrar. }\end{array}$ & $\begin{array}{l}\text { Também tem lugar bonito, } \\
\text { Pra turistas passear, } \\
\text { Templos, bosque, e praças, } \\
\text { Venha um dia visitar! } \\
\text { E quando vir pra cá! } \\
\text { Vá também ao K.K.K.K! }\end{array}$ \\
\hline
\end{tabular}

Mesmo que o critério observação dos elementos da poesia seja apenas um dentre quatro, pela frequência com que esses elementos apareceram nas oficinas, foi dado a eles um espaço maior na análise, com o intuito de preparar a discussão no capítulo 3 , de como se caracterizam os gêneros poéticos em materiais de orientação para a escrita. 
Assim além da rima mencionada em duas oficinas (6 e 7), outro recurso sonoro também presente (oficina 7) do qual a aluna fez uso foram assonâncias. Os ecos dos sons vocálicos atravessam o poema também de forma irregular, criando laços coesivos que coincidentemente ocupam o espaço de uma estrofe e depois são substituídos por outros. A insconstância quanto aos procedimentos parece ser a tônica da estrutura composicional e também um traço de estilo para a aluna, uma tentativa de antropofagização dos pontos de vista muitas vezes parafrasticamente, ao dispô-los em sequência.

Ainda quanto aos recursos sonoros, é possível observar que a assonância da vogal “i” é a única que permanece em mais de uma estrofe $\left(1^{\mathrm{a}} ; 3^{\mathrm{a}}, 5^{\mathrm{a}}, 8^{\mathrm{a}}\right)$ provavelmente pela importância da vogal no nome da cidade, situado na sílaba tônica, "Registro". O eco de um som relevante para a construção do tema, nesse caso, indica como as "intuições" da alunapoetisa foram constituídas pelas leituras e como em sua concepção de poema há a noção de que o trabalho sonoro, além da rima, é significativo.

Um elemento dos gêneros poéticos, não abordado de forma explícita nas oficinas, o metro, confirma a pré-existência de um repertório da aluna, pois mesmo não havendo uma predominância de metro, a redondilha maior ${ }^{34}$ aparece em 12 dos 35 versos. Ao lado desse metro, aparecem os versos aparentemente de 8 sílabas e os versos de 9 e 10 sílabas. A oscilação resultante cria uma falsa regularidade em algumas estrofes, como a $7^{\mathrm{a}}$ e a $8^{\mathrm{a}}$. Em outras estrofes, o que assegura uma idéia de encadeamento do poema é a rima, em função dessa irregularidade. A metrificação seguiria regras que não se restringem na contagem de sílabas métricas pela escansão. No caso de versos regulares, segundo Mello (2001, p. 8),

\footnotetext{
teoricamente qualquer segmento de dez sílabas é um decassílabo, mas, para efeito de poesia medida, só se cogita dos segmentos que além de serem silabicamente subordinados à citada medida, estejam devidamente ritmados, ou seja, apresentem as sílabas tônicas em determinadas posições pré-estabelecidas, através das quais o ritmo estético se manifesta.
}

Embora no caso dos poemas dos alunos ser tão rígido quanto a um elemento composicional, como o metro, signifique perder o horizonte do percurso, na afirmação de Mello é possível identificar a questão da irregularidade do ritmo no metro (os acentos) como um caminho para que outros discursos, provenientes de outros gêneros se infiltrem no poema

\footnotetext{
34 “A redondilha maior, esse verso melódico, além de muito frequente na letra das canções folclóricas e populares, aparece em poemas de todas as épocas, em Portugal e no Brasil. (GOLDSTEIN, 2006, p. 38)
} 
Mesmo em outras categorias de metrificação, esses versos não se enquandram, pois tampouco podem ser classificados como livres, uma vez que estes se constituem em oposição aos versos metrificados, como afirma Bandeira: "Ora, no verso-livre autêntico o metro deve estar de tal modo esquecido que o alexandrino mais ortodoxo funcione dentro dele sem virtude de verso medido." (1984, p. 45). A aluna não demonstra ter "esquecido" o metro. De fato, ela busca um metro, a redondilha maior, do qual se aproxima ora pela oralização do verso ora pela distribuição das palavras graficamente. Talvez por ter percebido que "o verso de sete sílabas, heptassílabo ou redondilha maior, é o mais simples, do ponto de vista das leis métricas. Basta que a última sílaba seja acentuada; os demais acentos podem cair em qualquer outra sílaba." (GOLDSTEIN, 2006, p. 36) Essa busca de metros próximos, indica que não houve dessa maneira a superação da métrica. Qual seria, porém, a causa para haver a quebra do metro predominante e da metrificação mais coesa? Uma resposta possível é a forma como essas tentativas de se chegar até o metro se configuram. O repertório anterior da aluna e a experiência imediata com as oficinas estabelecem representações do que seriam os elementos caracterizadores do poema, porém ao lado dessas formas estáveis, surgem as vozes presentes nos discursos alheios (legitimados pelas características do Prêmio) que trazem suas estratégias textuais originadas em outros gêneros com outros tratamentos dados a esse mesmo tema. Assim, em algumas estrofes do poema, é possível encontrar marcas dessas outras vozes, na forma de enunciados da esfera da publicidade, e das narrativas históricas, que acabam por interferir no estabelecimento de um ritmo dos gêneros poéticos.

Como se observou, a oscilação de rima e metro indica igualmente uma elaboração nos "elementos da poesia" ainda iniciante, parece ser um rascunho. A fixação desse meio de percurso em um objeto supostamente final pode ser resultado do tempo que a oficina oferecia para os alunos estabelecerem sua "obra-prima" ou da incipiente "apropriação"35 das outras vozes. Logo na $1^{\mathrm{a}}$ estrofe, surgem os poemas fundadores, "Canção do exílio" e "Meus oito anos". A "Canção do Exílio" soa em vários momentos, principalmente pela apresentação dos "primores" da terra e pelo uso do "cá" de tom eufórico. De "Meus oito anos", de Casemiro de Abreu, está presente a primeira estrofe:

\footnotetext{
${ }^{35}$ A apropriação feita pela aluna indica processo semelhante ao da apropriação que se encontra nas teorias de tradução em que "Traduzir seria apropriar-se do texto dito "original". E toda apropriação, por sua vez, se processaria mediante exercício de violência. Longe de tentar eliminar a violência do ato tradutório, ao teórico de tradução caberia perguntar quais as condições que propiciaram a violência e quais as formas de resistência que as vítimas oferecem com ou sem êxito." (RAJAGOPALAM, 2000, p. 124) Essa violência pode ser maior ou menor, no caso do poema "Registro, cidade querida", os discursos oferecem maior resistência e a apropriação apresenta menor êxito.
} 


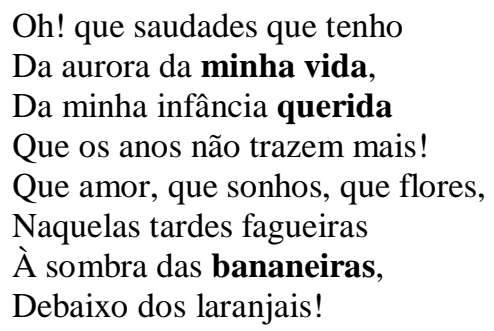

Ambos os poemas têm como metro, a redondilha maior e podem seer entrevistos nos versos "Na minha vida, terra querida" e "Pássaros cantam na bananeira/ Às margens do Rio Ribeira”. Essas são vozes esperadas na produção textual de um gênero, porque pertencem aos gêneros poéticos e porque fazem parte do repertório que a escola oferece aos alunos. "Canção do Exílio" estava na antologia do fascículo "Poetas da Escola"; já "Meus oito anos" pode ter sido apresentado à aluna em outro momento em sala de aula ou não.

Essas vozes, modelos para a produção dos poemas, nas estrofes seguintes serão substituídas por outras. Em alguns trechos, a voz da aluna se alinha à voz do historiador ( $4^{\mathrm{a}}$ estrofe); em outros, é a voz da publicidade que surge como em "Pérolas da Mata Atlântica"; "Registro, cidade amiga" que soam como slogans. Talvez seja essa a razão desses trechos com oscilações. As vozes alheias à esfera literária (embora apresentem alguns dos recursos identificados como poéticos no fascículo, como o slogan; o anúncio publicitário e afins) vão intensificando sua presença e, nas últimas estrofes, o apelo ao outro parece ter saído dos reclames dos antigos almanaques: "Registro tem muita escola / para seu filho estudar". Nesse trecho, também é possível identificar a quem se dirige o poema; trata-se de um adulto que é chamado para a cidade. A aluna-poetisa estimula o interesse dessa pessoa pelas comodidades de que se pode usufruir (escola para quem quiser morar na cidade, lugares para compras e passeios para quem quiser fazer turismo).

A escolha do adulto como interlocutor promove um afastamento drástico do universo de elementos que fariam sentido para um aluno da $5^{\text {a }}$ série $\left(6^{\circ}\right.$ ano), porque a aluna tem de projetar expectativas de outros. Ao incorporá-las para dar sentido ao seu texto, diminui sua própria voz, buscando aquelas que lhe parecem fazer sentido para um adulto. Paes afirma que isso pode ocorrer com alunos dessa faixa etária, em que a memória discursiva pode agir como um limitador, pois se trata de fonte mais acessível, que requer menos esforço para o desenvolvimento da postura autoral. Em seu ensaio "Infância e Poesia"36 demonstra como as

\footnotetext{
${ }^{36}$ Versão eletrônica disponível em http://www1.folha.uol.com.br/fsp/mais/fs09089806.htm Acesso em 14-102009.
} 
crianças e os poetas se assemelham e como, a partir de certa idade, os pequenos são, por assim dizer, contaminados com o pragmatismo, afastando-se da poesia:

Esse senso já se mostra ativo nas crianças escolarizadas da faixa dos dez anos ou mais, que se vão progressivamente impregnando das idéias feitas, preconceitos morais e clichês de expressão inculcados em casa e na escola, bem como dos lugares-comuns e slogans publicitários subconscientemente absorvidos da televisão. Contra o embotamento induzido por tais automatismos de linguagem e de percepção, pode exercer uma ação desbloqueadora das mais salutares a leitura regular de poemas. Poemas cuja visão de mundo ponha em xeque esses automatismos, quer no nível dos conteúdos mentais, quer no nível da expressão verbal, já que uma visão dessa natureza só a pode veicular uma linguagem inovadora como a da poesia moderna. (PAES, 1998)

O poema tem esse poder desbloqueador, porque devolve ao aluno potência, especialmente por permitir a manipulação da linguagem, pela busca de caminhos que, mesmo tendo a língua no fim do percurso, possibilitam experimentações admitindo a entrada de outras vozes pelo filtro da visão do aluno-poeta.

Ao fim da leitura, a cidade de Registro surge como um local agradável para o turismo e para morar. A imagem de um grupo coeso de pessoas trabalhando para o bem comum também se insinua pelo uso da primeira pessoal do plural nos versos 13, 14 e 19 que coloca em segundo plano os pronomes possessivos "minha" (versos 2 e 22) e os verbos em primeira pessoa que fariam a vinculação da visão expressa no poema à aluna-poetisa (versos 6 e 9). Da mesma forma, a presença do grupo em "gente diferente" e demais tipos de gente (estrofe 3) e "povo" (verso 20) desloca a voz pessoal para essa voz grupal. Porém, ainda não é o grupo que ficará no primeiro plano, uma vez que o lugar exaltado parece assumir essa posição. $\mathrm{O}$ ethos que a aluna-poetisa assume é de morador, como se isso fosse suficiente para descrevêla ou para valorar quem ela é. Constitui-se assim um ethos que existe como porta-voz do grupo - um ethos coletivo (AMOSSY, 2005)

Há, em cada uma das estrofes, um coro de vozes ora em uníssino ora harmonizando, diante do qual a aluna tenta se colocar como solista ao organizá-las. Essa organização, como acontece nos gêneros poéticos, institui partes presumidas que o leitor não verá. A ele só é dado pressupor, buscar, trabalhar com o texto. Não se trata de forma alguma de debilidade do poema da aluna, uma vez que, segundo Bakhtin e Voloshinov (1926/76, p. 11), "Na literatura, julgamentos de valor presumidos têm um papel de particular importância. Poderíamos dizer que uma obra poética é um poderoso condensador de avaliações sociais não articuladas cada palavra está saturada delas. São essas avaliações sociais que organizam a forma como sua expressão direta." A questão então é como essas avaliações sociais, via outros discursos, 
se organizam no texto dela, uma vez que Bakhtin e Vosloshinov entendem que: "a significação avaliativa da forma é especialmente óbvia no verso. O ritmo ou outros elementos formais do verso abertamente expressam uma certa atitude ativa em direção ao objeto." (1926/76, p, 11) A ausência de um ritmo único nesse poema de tom laudatório (irregularidades nas rimas, metro, figuras de linguagem) indica a intrincada relação entre o discursivo e os elementos formais na posição autoral - confronto que a aluna trava ainda sem as ferramentas apropriadas - dessa forma sua voz não é solista, mas é possível ouvi-la aqui e ali no coro. 


\subsection{Igaratá}

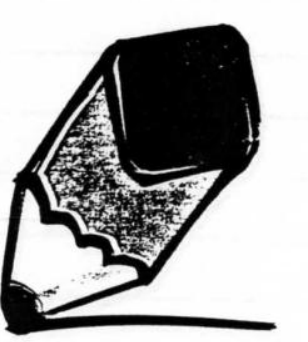

P R E M I, 0 Esc:evemóo

ofuturo tha

uma iniciative da fundacso itai social

Juà escoià concorre. É o brasil ganha.

Título: Igariatá

Igantá, a pousia sestá ne ar.

Nấo sei como cemplusan

Mas im prosa, verisás an rimas.

ch sua firtánes en ven centar

Quintios anos se parsuarana.

a ontiana cidade inundon

$E$ alguns me compraruman

Que tada a paputazáa cinaren

Irintaza, dar a molânestia.

Tha a ordiem zira se mudar

Par = gaverna exigia,

Muita ógua represon.

Em carasas, a p', camininás on a comala..

a mudanpa comecon

Entre lógrimas e inicio de saudader

Um nave horigante se proficton.

Cara nava, vida nava.

6 progresso comezon

Hofe só resta a lomeranca

De um tenpra ruism que passan. 
Vierem rojas, vierems fótivas

Lis ruas a prupiño asfoeton

Heje ró resta a bemetang

Li un tempor ruim, mas passeu.

Mair vida a moin forer,

Muita famiécie shesou.

tera lem aromodién

Inais taivres ne vrion.

Jagajar, Iramperter, escelas.

6 pragresso comitomiar

Para instrmir mais criansar

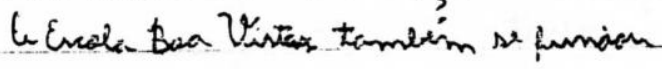

Para finalizan

Um acróstice en ver formark

Com o fims deraporar,

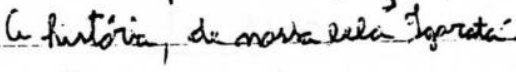

I ganatió, hale mithes Lugan nác há

Eastour anos para se formar.

A mada será, per tador que a visistar

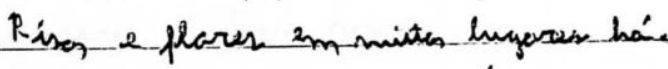

A dera 2 raspeilada sempre será.

Transformadar ressurigioa, das...

A guas de Jopratá 


\begin{tabular}{|c|c|c|}
\hline \multirow{2}{*}{$\begin{array}{l}\text { Série } \\
\text { Sexo }\end{array}$} & \multicolumn{2}{|l|}{$4^{\mathrm{a}}$} \\
\hline & \multicolumn{2}{|l|}{ Masculino } \\
\hline \multicolumn{2}{|c|}{$\begin{array}{l}\text { Igaratá } \\
1 \text { Igaratá,a poesia está no ar. } \\
2 \text { Não sei como começar } \\
3 \text { Mas em prosa, versos ou rimas... } \\
4 \text { A sua história eu vou contar } \\
\text { 5Quantos anos se passaram } \\
6 \text { A antiga cidade inundou } \\
7 \text { E alguns me confessaram } \\
8 \text { Que toda a população chorou. } \\
\text {, dor e melancolia. } \\
\text { ordem era se mudar } \\
\text { governo exigia, } \\
\text { água represar. } \\
\text { oças, a pé, caminhões ou a cavalo... } \\
\text { ança começou } \\
\text { ágrimas e início de saudades } \\
\text { vo horizonte se projetou. } \\
17 \text { Casa nova, vida nova. } \\
18 \text { O progresso começou } \\
19 \text { Hoje só resta a lembrança } \\
20 \text { De um tempo ruim que passou }\end{array}$} & $\begin{array}{l}\text { 21 Vieram lojas, vieram fábricas } \\
\text { 22 As ruas o prefeito asfaltou } \\
\text { 23 Hoje só resta a lembrança } \\
\text { 24 De um tempo ruim que passou } \\
\text { 25 Mais vida e mais flores, } \\
\text { 26 Muita família chegou. } \\
\text { 27 Para bem acomodá-lo } \\
\text { 28 Mais bairros se criou. } \\
\text { 29 Igrejas, Transportes, escolas. } \\
\text { 30 O progresso continuou } \\
\text { 31 Para instruir mais crianças } \\
\text { 32 A Escola Boa Vista também se fundou } \\
\text { 33 Para finalizar } \\
\text { 34 Um acróstico eu vou formar } \\
\text { 35 Com o fim de reforçar, } \\
\text { 36 A história, de nossa bela Igaratá. } \\
\text { 37 Igaratá, hoje melhor lugar não há. } \\
\text { 38 Gastou anos para se formar. } \\
\text { 39 Amada será, por todos que a visitar. } \\
\text { 40 Risos e flores em muitos lugares há. } \\
\text { 41 Adora e respeitada sempre será. } \\
\text { 42 Transformada e ressurgida, das... } \\
\text { 43 Águas de Igaratá. }\end{array}$ \\
\hline
\end{tabular}

O poema "Igaratá" atende aos critérios apresentados pelo Prêmio - pertinência ao tema proposto e busca de informações sobre o tema. Surgem nos versos os "moradores" e "suas peculiaridades" que formaram e formam hoje Igaratá (versos 7 e 8: "E alguns me confessaram"/ "Que toda a população chorou"; verso 26: "muita família chegou”), tendo como fio condutor a história da cidade que foi inundada e reconstruída (versos 41 e 42: “transformada e ressurgida das..."/ “Águas do Igaratá”).

Ao longo das estrofes, o aluno apresenta o povo de Igaratá e sua história. Esse tratamento dado ao tema pode ser associado ao poema épico, assim como o caracteriza D’Onofrio, “o termo grego epos, que significa narração, designava também um tipo de verso, o hexâmetro, composto de seis pés, usado para poemas longos que exaltavam os feitos heróicos das divindades ou de homens ilustres. Tal forma métrica passou a designar um tipo de poesia, a épica, a palavra narrada, chamada também de epopéia.” (2007, p. 97) O aluno segue parte dessa estrutura ao anunciar na $1^{a}$ estrofe que seu objeto é a história de Igaratá, porém ele não conta todos os fatos, concentra-se na mudança da cidade a partir da construção 
da represa e consequente reconstrução; o que permitirá a ele exaltar as ações dos moradores, como é próprio do poema épico.

Dessa forma o tom do poema se alinha ao da narração épica, a qual, "além de verter sobre um fato bélico grandioso, historicamente acontecido, mas idealizado pela imaginação coletiva criadora de mitos e de lendas, está diretamente relacionada com o surgimento ou o progresso de uma nacionalidade." (D’ONOFRIO, 2007, p. 99) No caso do poema, o que o aluno entende como seu espaço público.

A assunção dessa posição em relação ao tema (os atos do povo de um lugar em relação a uma situação conflitante) também indica que o aluno foi sensibilizado pela poesia popular, principalmente o gênero cordel, em que as ações das pessoas, tomadas como membros de uma comunidade ou como representantes dela, são temas constantes. Aliado a essa tematização, na poesia popular, a distribuição em estrofes de quatro versos, com rimas alternadas é bastante frequente. Essa estabilidade da forma reflete um lugar em que o aluno encontra legitimados os elementos da poesia com os quais deveria lidar segundo as instruções do Prêmio.

$\mathrm{Na}$ oficina 8, "Conhecendo poesia popular", há a apresentação do cordel (no box "Para saber mais"), com os traços épicos:

Cordel é um estilo de poesia popular da tradição nordestina. Cantada ou declamada, está presente na maioria dos festejos da comunidade sertaneja: feira, festas religiosas, comícios etc. é uma poesia narrativa, ou seja, conta uma história. Geralmente, o tema é o cotidiano, a denúncia dos sofrimentos do povo, a exaltação de heróis e tipos populares, as lendas ou tradições nativas. (....) (PDE, p. 34)

Esses caracterizadores do gênero cordel aparecem no poema do aluno, não somente em relação ao tema, como também no uso diversificado de recursos poéticos. Ao lado das rimas (indicadas por cores), há o uso do paralelismo sintático (indicado pelas maiúsculas) que auxilia a organização do ritmo.

\section{QUADRO 1}


Igaratá

$\left(1^{\mathrm{a}}\right)$

1 Igaratá,a poesia está no ar. (12)

2 Não sei como começar (7)

3 Mas em prosa, versos ou rimas... (8)

4 A sua história eu vou contar (8)

5Quantos anos se passaram (7)

$6 \mathrm{~A}$ antiga cidade inundou (8)

$7 \mathrm{E}$ alguns me confessaram (6)

8 Que toda a população chorou. (9)

9 Tristeza, dor e melancolia. (9)

10 Mas a ordem era se mudar (8)

11 Pois o governo exigia, (7)

12 Muita água represar. (6/7)

13 Em caroças, a pé, (6) caminhões ou a cavalo (7)...(13)

14 A mudança começou (7)

15 Entre lágrimas e início de saudades (11)

$16 \mathrm{Um}$ novo horizonte se projetou. (10)

17 CASA NOVA, VIDA NOVA, (7)

18 O progresso começou (7)

19 Hoje só resta a lembrança (7)

20 De um tempo ruim que passou (8)
21 VIERAM $о и$ LOJAS, VIERAM FÁBRICAS (9)

22 As ruas o prefeito asfaltou (9)

23 Hoje só resta a lembrança (7)

24 De um tempo ruim que passou (8)

25 MAIS VIDA e MAIS FLORES, (6)

26 Muita família chegou.(7)

27 Para bem acomodá-lo (7)

28 Mais bairros se criou. (6)

29 Igrejas, Transportes, escolas. (8)

30 O progresso continuou (8)

31 Para instruir mais crianças (7)

32 A Escola Boa Vista também se fundou (13)

$$
\left(9^{\mathrm{a}}\right)
$$

33 Para finalizar (6)

$34 \mathrm{Um}$ acróstico eu vou formar (8)

35 Com o fim de reforçar, (7)

36 A história, de nossa bela Igaratá. (12)

37 Igaratá, hoje melhor lugar não há. (12)

38 Gastou anos para se formar. (9)

39 Amada será, por todos que a visitar. (13)

40 Risos e flores em muitos lugares há. (12)

41 Adora [DA?] ${ }^{37}$ e respeitada sempre será.

(11)

42 Transformada e ressurgida, das... (8/9)

43 Águas de Igaratá. (7)

Como se observa nas marcações no quadro 1, as rimas, consoantes (e uma ocorrência de toante, versos 13 e 15) estão dispostas de forma alternada realçadas pelas cores; e o uso de paralelismo sintático de verso cindido no meio, sempre em posição inicial na estrofe $(5,6$ e 7$)$ ou verso em três partes (estrofes 3,8). O paralelismo também aparece na repetição dos versos "Hoje só resta a lembrança / De um tempo ruim que passou" que soam nessas duas estrofes como uma espécie de refrão. Esses versos lembram os da canção "Lembrança" (2000), de Flávio José: "O nosso amor foi tão lindo / Tão lindo enquanto durou / Hoje só resta a lembrança / Do tempo que passou / Das festas de vaquejadas / E do alazão corredor // Hoje só resta a lembrança / Até a esperança de mim se afastou". Porém como não se trata de verso raro ou construção inédita no cancioneiro da música popular, é possível que seja um eco ou uma voz que irrompe a memória sem que se dê conta disso, quando se busca uma certa excelência já reconhecida.

\footnotetext{
${ }^{37}$ No verso 41 , há a dúvida se houve um erro de grafia ou se há uma inadequação na estrutura paralelística. Provavelmente pela rede de elementos do poema seja "adorada".
} 
Como consequência, o poema traz um ritmo construído pela rima e pelo paralelismo, que criam uma superfície de homegeneidade, quebrada em algumas estrofes pela existência de metros diversos (versos de 6, 7, 8, 9, 10, 11, 12 e 13), que acabam por suspender a construção de uma imagem vinculada ao enunciador responsável pelo poema. Essa voz, graças ao ritmo múltiplo sem qualquer tipo de traço centralizador, parece ser construída por outras que, por vezes, tomam sua posição de solista. São elas que promovem versos polimétricos na suposta organização.

A voz principal em primeira pessoa abre e encerra o poema em atitude metalinguística (antes de começar o acróstico que parece um anexo ao texto em si). Esses momentos emolduram dois tempos: o tempo da escrita que apresenta, de forma simulada nos versos, o tempo da narrativa.

O tempo da escrita está marcado em duas estrofes: a primeira e a nona. Na primeira, o traço a ser destacado é a hesitação. Ele anuncia o que vai fazer mesmo que não saiba como fará, pois a poesia está no local (“Igaratá, a poesia está no ar”). Questionando suas habilidades que são inferiores às da cidade naturalmente poética ("Não sei como começar / Mas em prosa, versos ou rimas... / A sua história eu vou contar.”), o enunciador também indica não saber como lidar com o gênero, uma vez que "prosa" e poesia não são modos de compor de igual natureza e valor, mas ele as justapõe como estrutura composicional possível para o poema que pretende fazer numa espécie de paradoxo. A hesitação, tal como se apresenta aqui, também pode ser entendida como efeito retórico em que o orador anuncia sua inabilidade para indicar a sua posição em relação ao objeto, que é sempre maior que a abordagem feita. Esse tipo de recurso, nascido na língua oral, aparece também na língua escrita formal guiada pela Retórica e hoje ainda está presente nas formas poéticas populares como o cordel. Em virtude do contato que os alunos envolvidos no concurso tiveram com a poesia popular, esse recurso poderia ser efeito dessa organização argumentativa que colocaria o leitor em uma posição mais receptiva, graças à imagem de ethos humilde e comprometido com sua ação no poema. Na nona estrofe, no entanto, a hesitação é substituída por uma insuficiência que o enunciador pretende corrigir com o acróstico com o nome da cidade. Essas duas estrofes revelam, ao fim, um ethos persistente, mas um pouco inseguro.

A intertextualidade de estrutura composicional (com o cordel) é bastante significativa, principalmente quando "as origens do cordel podem ser traçadas até as tradições medievais da literatura européia. As canções de gesta, as narrativas históricas, novelescas ou fantásticas, 
as histórias bíblicas e os exemplários (contos usados para ilustrar tratados morais) são algumas das fontes que contribuíram para o seu surgimento." (ITAÚ CULTURAL, s/d) Dessa forma, a literatura de cordel apresenta na sua história de constituição traços poéticos num percurso de prosificação. Como se observa na caracterização das canções de gesta e romances feita por Aguiar e Silva (1979, p. 249):

\begin{abstract}
Embora relacionado com as canções de gesta, o romance medieval distingue-se destas composições épicas tanto por elementos formais como por elementos do conteúdo: a canção era cantada, ao passo que o romance se destinava a ser lido e recitado; a canção de gesta ocupa-se da empresa das façanhas do herói que personifica uma acção coletiva, enraizada na memória de uma comunidade, ao passo que o romance se ocupa das aventuras de uma personagem, criatura de ficção, através do vário e misterioso mundo, apresentando um caráter descritivo-narrativo.
\end{abstract}

Assim o gênero cordel hoje condensaria as distinções e embates históricos de identidades entre esses gêneros em uma tensão de tempos como aponta Zumthor (1972 apud AGUIAR E SILVA, 1979, p. 249) a respeito de como a narrativa para ser lida se liberta das figuras de sons:

\begin{abstract}
A ficção, até então subordinada às exigências melódicas e rítmicas, e parcialmente determinada por elas, torna-se um dos dois planos de existência do texto: o outro é o da "escrita". Simultaneamente, a narrativa figura um real exterior e representa-se a ela própria como discurso: sinal ao mesmo tempo "de alguma coisa" e "para alguma coisa", revela-se a representação temporal (é um acaso que esta revelação coincida cronologicamente com o rápido desenvolvimento do comércio, com a intensificação da circulação de bens?); estabelece-se uma tensão entre o tempo próprio da narrativa e o tempo de uma palavra que a narrativa assume ficticiamente. Na canção de gesta, até mesmo na pastorela, a estrutura musical esbate esta dualidade fundamental da narrativa.
\end{abstract}

Com esses elementos, é possível observar como o embate dos tempos no poema do aluno se institui como na narrativa descrita por Zumthor, uma solução para os ritmos de outros gêneros prosaicos trazidos para o texto.

Nas demais estrofes, o enunciador passa a palavra para outros ("E alguns me confessaram"). Da mesma forma que a cidade é portadora natural da poesia, as vozes desses moradores têm o poder de construir o poético do texto, trazidos pelo enunciador. A história que eles contam de superação por causa da mudança da cidade de lugar, em virtude da construção da Represa Jaguari ${ }^{38}$ parece ter em si valor e força suficientes para tornar o texto poético. Esse é o segundo tempo, o histórico em que os processos assumem o lugar das pessoas ("a ordem era se mudar”; “a mudança começou”; “o progresso começou”). A figura

\footnotetext{
38 Os dados históricos sobre o deslocamento da cidade e seu ressurgimento podem ser encontrados em http://www.explorevale.com.br/cidades/igarata/historia.htm , acesso em 06-06-2008.
} 
de linguagem que assume o poema nesse momento é a metonímia. Talvez porque as pessoas não sejam tão importantes quanto sua atuação em momentos como aquele, de mudança, de incertezas, de expectativa. Nesse caso, há o uso de uma figura de linguagem significativa para a construção do tema, que mimetiza o que o aluno-poeta considera ser poético como o esforço, as dores, a perda da cidade. Essas imagens remetem ao discurso da esfera religiosa de orientação cristã de duas formas. A primeira se refere ao fato de a cidade ter ressurgido depois da construção da represa. A ressurreição, fato central para os cristãos, permite aos que crêem ter esperança; reforça a fé. A segunda forma de se vincular com o discurso da esfera religiosa está marcada pela diminuição da importância do "eu" para que o outro ocupe o lugar.

Ainda nesse tempo histórico, como a cidade não é espaço privado, surge nos versos outra formação discursiva, a da esfera política, indiciada por atores que passam a ser invidualizados. Em dois versos (11 e 22), esses atores são, respectivamente, o "governo" e o "prefeito". Trata-se, portanto, de uma história pública, que começa no movimento geral da cidade até chegar à fundação da escola Boa Vista, onde o aluno-poeta estuda. O deslocamento dos grandes espaços para o espaço mais próximo então se configura como estratégia textual para encerrar o texto. O aluno-poeta retorna ao tempo da escrita e ao processo metaenunciativo iniciado na primeira estrofe, vivenciados no espaço da escola.

A finalização do texto - com um poema dentro de um poema - indica outra estratégia retórica. Ao dividir o processo com o leitor, a adesão deste pode se dar de forma mais completa, pois foi enredado na elaboração do texto mesmo que na posição de espectador. Trata-se de recurso sofisticado, que indicaria maturidade do aluno-poeta, só questionada pelo uso do verbo "reforçar" (penúltima estrofe). Esse verbo abre espaço para uma insuficiência que o acróstico final parece não suprir, porque, nele, não se define o que aparecia carregado de possiblidades nas estrofes anteriores. Não se define ritmo e métrica; tampouco aparece o trabalho com o paralelismo sintático. Não haveria necessidade de colocar o acróstico que aparece ali por força (provavelmente) das orientações, como se fosse etapa necessária, uma vez que é o um dos dois gêneros poéticos a aparecer de forma explícita no fascículo.

Na última estrofe, o processo é finalizado com coerência em relação à proposta do poema, por meio do retorno da idéia de que o local é suficiente para garantir o poético, pois Igaratá é o sujeito ou objeto de quase todas as frases indicando a força atribuída a ele. Onde está a voz do enunciador? O lugar parece tê-la absorvido ou parece não ser suficiente para 
mobilizá-lo, daí o uso da voz alheia, da voz já experiente, ou da voz que se ocupa disso, a da res publica. $\mathrm{O}$ enunciador se coloca como um instrumento para que essa grandeza se mostre.

Esse modo de tematizar a cidade no poema confere importância (empurrando o enunciador, com uma certa força promovendo seu silenciamento) a espaços em que ele só diz o que lhe indicaram como relevante. Qual a avaliação do aluno? Qual a valoração que faz daquilo que lhe foi apresentado? Surge como uma questão: como tomar posse do discurso alheio afastando-o depois de se valer dele? 
78

2.3 Vivendo entre araçás, bois e progresso

Suplew

Titulo: Vivendo entre araçás, bois e pragresso.

Q higar em que vivo

E'Tambén onde nasci

É a mais bela cidade

$P R E M I O$ Las poucas que conteci.

ofutivio that

Sou ainda muito fovem E pouca coisa en ${ }^{2}$ iur mas aprendi uma história Wue se passon por aqui.

Foi no início do século Wul acabou de passar: hasce no Norolste Pulista a Vila dos Gracás.

Foi chamada Ciracatuba Por causa de uma frutinha, Que nascia por aqui \& em todo liegar tinha

Jerra de vasto território delvagem el desconhecido. Qnde só tinha indíglnas he civilizacãa desprovidos 
79

Eram indios caingangues Iribo sebagem e guerreira, $\varepsilon$ não queriam os brancos $C^{\prime}$ ' dentro de suas frontiras.

Lluando a estrada de ferro. Por aqui teve que passar, Construir - se un vilarejo Para os operários abrigar.

Cissim nascen Craçatuba Com a Ferrovia Noraiste, Para traniportar o progresso le todo o lentro-Ceste.

Muita luta aqui se travou muitos homens aqui tombaram, muite sangue se derramou Mas a cidade edificaram.

$E$ hoje ela aqui está Cloriasa e altancira,

E capital da noroeste

E cidade hospitaliira.

E a minha Craçatuba Cidade jovem e progressista "Capital do boi gordo" ie todo o interior paulista. 
80

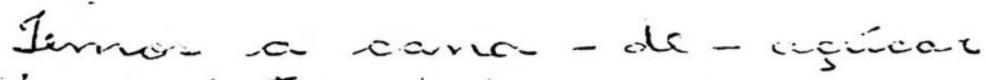
Lhis i Tamitén mareo importernte,

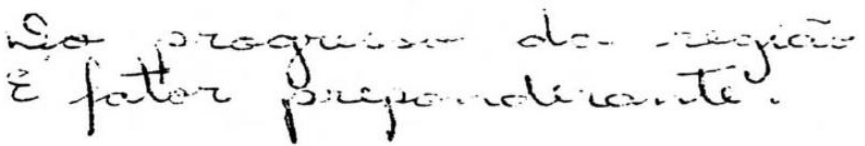

Eista sana surgi a álicool fine os ceviras piàn ind açõos, Imyentisianando can isso Ll futirir da nagazo.

Iernos un parque industrial Live der anyiecjo at pere

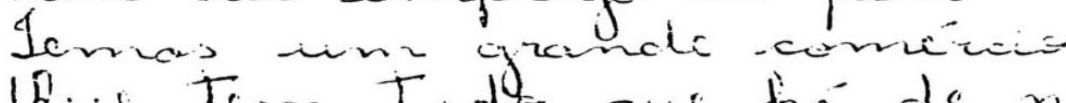
Line tem thide que há de nove.

Jemos neasis rie Iietâ

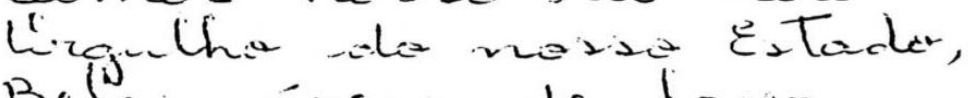
Beloris áreas de lazer E shitrer por todo Shado. É minho cidade me orgulto Mara tomán la melhor.

Ulina soisa oqui proncto hestar minka paice idade: Quando en crescer guero fazer minto por minha siclade. 


\begin{tabular}{|c|c|c|c|}
\hline Série & \multicolumn{3}{|l|}{$5^{a}$} \\
\hline Sexo & \multicolumn{3}{|l|}{ Masculino } \\
\hline & Vivendo entre araçás, bois e progresso & 37 & E hoje ela aqui está (7) \\
\hline & & 38 & Gloriosa e altaneira, (7) \\
\hline 1 & O lugar em que vivo (6) & 39 & É capital da Noroeste (8) \\
\hline 2 & É também onde nasci (7) & 40 & É cidade hospitaleira. (7) \\
\hline 3 & É a mais bela cidade (7) & & \\
\hline 4 & Das poucas que conheci (7) & 41 & É a minha Araçatuba (7) \\
\hline & & 42 & Cidade jovem e progressista (8) \\
\hline 5 & Sou ainda muito jovem (7) & 43 & "Capital do boi gordo" (6) \\
\hline 6 & E pouca coisa eu vivi, (7) & 44 & De todo o interior paulista. (7) \\
\hline 7 & Mas aprendi uma história (7) & & \\
\hline 8 & Que se passou por aqui. (7) & 45 & Temos a cana-de-açúcar (7) \\
\hline & & 46 & Que é também marco importante, (7) \\
\hline 9 & Foi no início do século (7) & 47 & Do progresso da região (7) \\
\hline 10 & Que acabou de passar: (7) & 48 & É fator preponderante (7) \\
\hline 11 & Nasce no Noroeste Paulista (9) & & \\
\hline 12 & A Vila dos Araçás. (7) & 49 & Desta cana surge o álcool (7) \\
\hline & & 50 & Que os carros põem em ação, (7) \\
\hline 13 & Foi chamada Araçatuba (7) & 51 & Impulsionando com isso (7) \\
\hline 14 & Por causa de uma frutinha, (7) & 52 & O futuro da nação (7) \\
\hline 15 & Que nascia por aqui (7) & & \\
\hline 16 & E em todo lugar tinha. (6) & 53 & Temos um parque industrial (8) \\
\hline & & 54 & Que dá emprego ao povo (7) \\
\hline 17 & Terra de vasto território (8) & 55 & Temos um grande comércio (7) \\
\hline 18 & Selvagem e desconhecido, (8) & 56 & Que tem tudo que há de novo. (7) \\
\hline 19 & Onde só tinha indígenas (7) & & \\
\hline 20 & De civilização desprovidos (9) & 57 & Temos nosso rio Tietê $(7 / 8)$ \\
\hline & & 58 & Orgulho do nosso Estado, (7) \\
\hline 21 & Eram índios caingangues (7) & 59 & Belas áreas de lazer (7) \\
\hline 22 & Tribo selvagem e guerreira, (7) & 60 & E clubes por todo lado. (7) \\
\hline 23 & E não queriam os brancos (7) & & \\
\hline 24 & Cá dentro de suas fronteiras.(8) & 61 & Da minha cidade me orgulho (7) \\
\hline & & 62 & E sua história sei de cor, (7) \\
\hline 25 & Quando a estrada de ferro $(6 / 7)$ & 63 & Mas muita coisa ainda falta (7) \\
\hline 26 & Por aqui teve que passar, (8) & 64 & Para torná-la melhor. (7) \\
\hline 27 & Construiu-se um vilarejo (7) & & \\
\hline 28 & Para os operários abrigar (9) & 65 & Uma coisa aqui prometo $(7)$ \\
\hline & & 66 & Nesta minha pouca idade: (7) \\
\hline 29 & Assim nasceu Araçatuba (8) & 67 & Quando eu crescer quero fazer (8) \\
\hline 30 & Com a Ferrovia Noroeste, (9) & 68 & Muito por minha cidade. (7) \\
\hline 31 & Para transportar o progresso $(8)$ & & \\
\hline 32 & De todo o Centro-Oeste. (6) & & \\
\hline 33 & Muita luta aqui se travou (8) & & \\
\hline 34 & Muitos homens aqui tombaram, (8) & & \\
\hline 35 & Muito sangue se derramou (8) & & \\
\hline 36 & Mas a cidade edificaram. (8) & & \\
\hline
\end{tabular}

No poema "Vivendo entre araçás, bois e progresso", uma predisposição para um ethos positivo surge da grafia do aluno, em sua corporalidade. A expectativa criada pela organização da letra é reforçada pela distribuição regular das estrofes (17 quartetos). Embora não seja um critério, esses traços propiciam o estabelecimento de um perfil de domínio que, aos poucos, vai se confirmando também na distribuição do metro e das rimas. Há o 
predomínio da redondilha maior e a variação do metro, na maioria dos versos, acontece para os mais próximos 6 e 8, diferença que, algumas vezes, desaparece nos modos de oralizar os versos. Aliados aos elementos sonoros, o paralelismo sintático reforça a idéia dessa elaboração, como ocorre na $9^{a}$ estrofe ("Muita luta aqui se travou, / Muitos homens aqui tombaram, / Muito sangue se derramou, / mas a cidade edificaram"), nos dois últimos versos da $10^{\mathrm{a}}$, continuando no primeiro da $11^{\mathrm{a}}$ estrofe ("É capital da Noroeste / É cidade hospitaleira. // É a minha Araçatuba"); e também nos dois primeiros versos da $12^{\mathrm{a}}$ ("temos um parque industrial / que dá emprego ao povo") com os versos da 14 estrofe ("Temos um parque industrial,/ que dá emprego ao povo / Temos um grande comércio, / com tudo que há de novo").

Esses elementos garantem a organização da forma que sugere domínio do tema e da estrutura composicional. No entanto, o que parece ser domínio também pode ser considerado como brecha para outras vozes ligadas não somente ao tema, mas ao processo de escrita do próprio texto. Nos poemas anteriores, não houve comentários a respeito de erros de concordância ou ortografia, por serem ocorrências esperadas para a faixa etária e por demonstrarem que os professores interferiram até certo ponto (pelas orientações para as reescritas) - ponto positivo para a atividade -, porém, no poema de Araçatuba, a interferência parece mais clara. Não somente as vozes institucionais surgem, uma vez que alguns desses discursos são esperados para a atividade, pois se previu $^{39}$ que as outras disciplinas como História e Geografia fornecessem dados para que o aluno-poeta pudesse desenvolver, a partir de um repertório a respeito da cidade, construído no desenvolvimento do concurso, a sua visão do local onde vive. Contrariamente a essa expectativa, o que se observa desde o título é uma estruturação que parece vir de outra voz que não a do aluno. Adjetivos como "vasto", "desprovidos", "gloriosa", "altaneira" e "preponderante" ao lado de verbos como "tombaram", "travou" e "edificaram" indiciam uma heterogeneidade mostrada, construída sobre discursos laudatórios que apagaram a voz do aluno-poeta.

A heterogeneidade mostrada "corresponde à presença localizável de um discurso outro no fio do discurso." (CHARADEAU; MAINGUENEAU, 2004, p. 261) e, entre as marcas para se identificar a presença do discurso outro, existiriam as formas não-marcadas e formas marcadas.

\footnotetext{
${ }^{39}$ Cf. citação da página 16 sobre a orientação do caderno "Cá entre nós” (p. 4).
} 
O co-enunciador identifica as formas não-marcadas (discurso indireto, alusões, ironia, pastiche...) combinando em proporções variáveis a seleção de índices textuais ou para-textuais diversos e a ativação da cultura pessoal. As formas marcadas, ao contrário, são assinaladas de maneira unívoca; pode tratar-se de discurso direto ou indireto, de aspas, mas também de glosas que indicam uma nãocoincidência do enunciador com o que ele diz (modalização autonímica). (CHARADEAU; MAINGUENEAU, 2004, p. 261)

No caso do poema, apenas uma forma é marcada: "capital do boi gordo" (verso 43) em que o slogan da cidade aparece de modo a ser entendido como tal. As demais formas são não-marcadas, - desde a escolha lexical, já mencionada, à organização sintática (inversão), como nos versos 27 e 28: “construiu-se um vilarejo / para os operários abrigar”.

Cabe ainda mencionar a presença das inversões sintáticas. No caso do poema, essas inversões não são incomuns, porque a exigência ou a manutenção da rima requer que as palavras se desloquem da ordem direta, porém, nesse caso, algumas das inversões não envolvem versos que rimam, como o verso 61, "da minha cidade me orgulho" ou ainda, o verso 65, "uma coisa aqui prometo". Esses versos parecem seguir um padrão, que seria uma forma não-marcada de discurso alheio. O mesmo pode ser transferido para o título em que o gerúndio (vivendo) seguido dos três substantivos (araçás, bois e progresso) resume a trajetória da cidade ilustrada nos versos do poema. Uma vez que resumir é tarefa bastante sofisticada para a idade, instauram-se mais uma vez dúvidas a respeito da negociação que se estende além das vozes na estruturação do poema em sua versão final.

A interferência do discurso do outro não se manifesta apenas em estruturas de organização privilegiada. Em alguns versos, usar o sintagma completo como em "Nasce no Noroeste Paulista" (verso 11) rompe com o metro até então regular. Essa é outra razão para supor que a pressão de um discurso alheio tenha tomado conta da voz do aluno-poeta assumindo esse espaço, ou seja, o uso considerado necessário da expressão exata representa uma intrusão no ritmo dado até aquele verso. O outro parece ora dilacerar a estrutura composicional, ora organizá-la de modo a parecer excessivamente arrumada.

O enunciador, no poema, aparece explicitamente em quatro estrofes:

\begin{tabular}{|l|l|l|l|}
\hline O lugar em que vivo & Sou ainda muito jovem & Da minha cidade me orgulho & Uma coisa aqui prometo \\
É também onde nasci & E pouca coisa eu vivi, & E sua história sei de cor, & Nesta minha pouca idade: \\
É a mais bela cidade & Mas aprendi uma história & Mas muita coisa ainda falta & Quando eu crescer quero fazer \\
Das poucas que conheci & Que se passou por aqui. & Para torná-la melhor. & Muito por minha cidade. \\
& $2^{\mathrm{a}}$ & $16^{\mathrm{a}}$ & $17^{\mathrm{a}}$ \\
\hline
\end{tabular}

Nas duas primeiras, a estrutura do cordel, da poesia popular tratada anteriormente reaparece: o enunciador apresenta o lugar como fonte de beleza e se coloca como incapaz para executar a tarefa, a razão dessa insuficiência, no caso do poema, é a pouca experiência. 
Retomando esses recursos clássicos da retórica, a solução é assumir o argumento da autoridade, mesmo que ele não esteja identificado claramente. A voz do outro, proveniente da história, assume o primeiro plano e o poema ganha contornos do épico. Finda a participação alheia, o enunciador retorna, domesticado por aquele discurso comprometido com a preservação de um projeto do outro que passa agora a ser dele. O pronome possessivo "minha" do verso 41 e a primeira pessoa do plural dos versos 45, 53, 55 e 57, "temos" reforçam essa passagem, que desemboca em um enunciador nutrido pelo discurso alheio, persuadido por esse discurso ("Da minha cidade me orgulho"). Trata-se de um discurso ufanista, correspondente à formação discursiva tradicional no Brasil, onde, em diversas ocasiões, foi promovido o apagamento da visão crítica.

No entanto, como as formações discursivas não podem ser consideradas de forma isolada, a noção de interdiscurso se torna central para a compreensão dos espaços instituídos nesse poema, compreendida aqui como

o conjunto de unidades discursivas (que pertencem a discursos anteriores do mesmo
gênero, de discursos contemporâneos de outros gêneros etc) com os quais um
discurso particular entra em relação implícita ou explícita. Esse interdiscurso pode
dizer respeito a unidades discursivas de dimensões muito variáveis: uma definição
de dicionário, uma estrofe de poema, um romance... Charadeau fala, assim, de
"sentido interdiscursivo" tanto para as locuções ou os enunciados cristalizados
ligados regularmente às palavras, contribuindo para lhes dar "um valor simbólico"-
por exemplo, para passarinho, unidades como "comer um passarinho" (1993,b:
316) - quanto para unidades muito vastas. (CHARADEAU; MANGUENEAU,
2004, p. 286)

O interdiscurso, nesse caso, permite localizar e também observar o trânsito desse discurso ufanista no poema e dele, para gêneros poéticos laudatórios em que tanto o enunciador se apresenta em um ethos cidadão, quanto o local, como espaço "utópico" (mesmo que a paisagem da janela possa negar a realidade reconstruída no poema).

A tensão marcada nesses modos de dizer instaurados pelo interdiscurso retoma a questão da interferência do professor na elaboração do poema. Quais papéis ele pode assumir? O de editor de textos? Nesse caso, o papel de uma, duas ou mais revisões, muitas vezes, edições dos textos pelo próprio autor ou por outros leitores (revisores, editores ou leitores instituídos pelo autor ou outra instância como tais), surge em Possenti (2008, p. 131 132) como uma proposta em que "esse conjunto de procedimentos seja considerado simplesmente como o processo de enunciação dos enunciados, desses enunciados." O autor afirma ainda "que se trata de uma questão de relevância histórica considerar os processos de enunciação tais como eles ocorrem. E se eles são assim quando se trata de textos escritos, e 
se, eventualmente, seu tempo de enunciação é de uma década, ou mais, se o "enunciado" é reescrito, sabe-se lá quantas vezes e por quantos "co-enunciadores", então é assim que ele deve ser considerado." Seria possível entender esse processo na escola sem retirar a autoria daquele escritor iniciante? No Prêmio, os relatos dos professores são essenciais para compreender qual o papel exercido por eles e pelo próprio aluno-poeta nesse percurso, assumindo que se trata de práticas de escrita constitutivas do processo de produção textual.

Haveria outro papel como o de orientador de produção textual? Para essa posição, as inserções reformulativas no texto passariam a comentários nas laterais do poema, abrindo espaço para a retomada do papel de reescritura para o aluno. Qual teria sido o posicionamento do professor envolvido na produção textual desse poema?

É de se esperar que os critérios de avaliação permitam que o professor se posicione. Eles têm como função secundária a atribuição de papéis para o docente na atividade desenvolvida. Seriam eles suficientes, porém, para agir no nível discursivo, ou seja, para permitir que professor identificasse em seu discurso, a força de uma estrutura acabada que retira a legitimidade do dizer alheio, nesse caso, do aluno?

Como se observou em outros poemas, a atitude valorativa em relação a certos discursos reforça identidades pré-estabelecidas não permitindo o desenvolvimento de tempos e espaços enunciativos para o aluno-poeta. Dessa maneira, ele não apreendeu o local para transformá-lo em poema, mas foi nele incorporado. 


\subsection{Diversão e poeira}

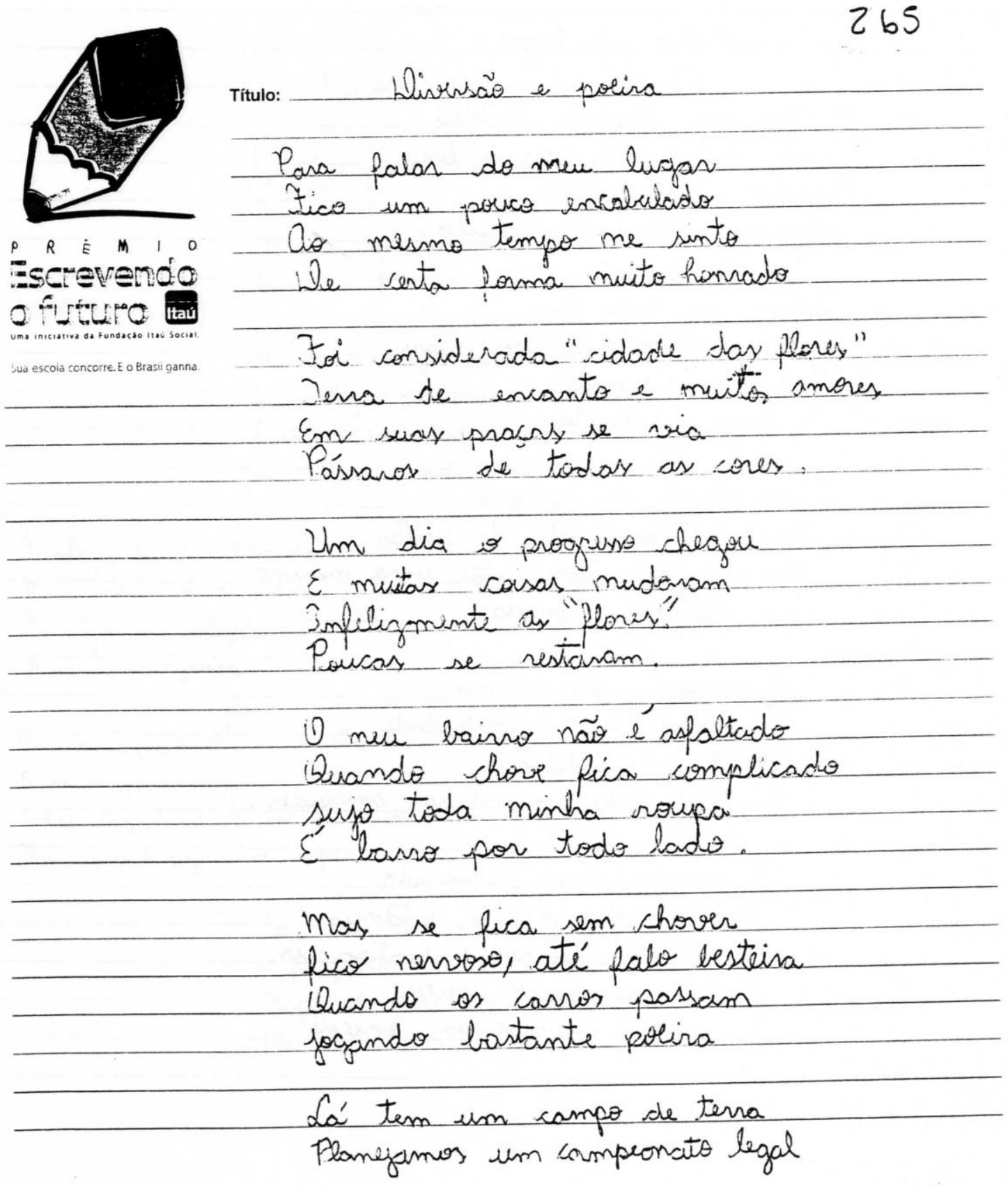


Jeve que ser adiado

Por causa de um manginal

Minha turma i animada

Ros reumimos para comersar

hiscutimar solve oy problemas

Que racontisem no lugan.

$\hat{\alpha}$ á tem um terreno boldu

inde ax pessoay jigem lixio

Fisemor um mutiräo

Deincando tudo no capricho.

Coesar de tudo isso

Tenho vroqutho do mese jusgar

As pessoas cappendi

Q amar e respertar.

roo finaus de simana

Minha turma gasta de agitan

the ajudam conquisitar una meniniza

que pretendo namorar.

A purenga das persoar

(1) sovrixo \& a sinceridade

Mu pass acreditar

the la' tenho verdadiras amizader.

E' numa na usturacada

Que curto minha infáncia

We muitos somhos l cratizacioers

E'lo' que quero crescer

$\varepsilon$ viver insquecively envosós. 


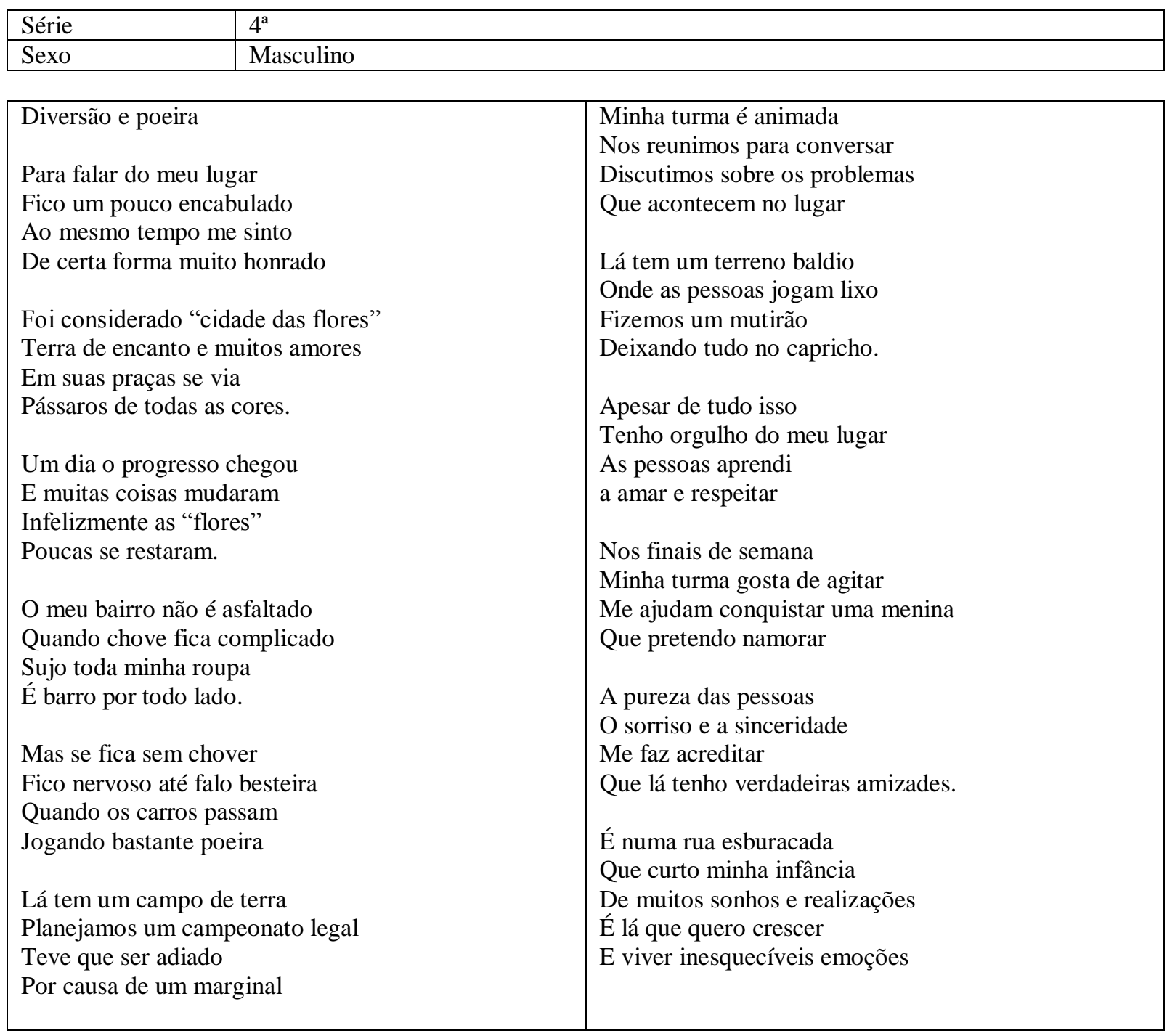

O poema "Diversão e poeira" apresenta estrutura semelhante à dos outros analisados. Há uma flutuação na métrica cuja aproximação com a poesia popular garante, pelos ecos da memória do gênero, um reconhecimento de algo que nos versos não está. Da mesma forma que o aluno-poeta ouve as reverberações dos poemas ouvidos e lidos em sala de aula, o leitor fica envolvido na rede sonora que preenche espaços, garantindo menor porosidade ao texto.

Diferentemente dos outros poemas, neste sequer é mencionado o nome ou a história do lugar onde o aluno-poeta vive. A alusão, que corresponde à forma marcada de heterogeneidade, é "cidade das flores", entre aspas. Esse sintagma garante a entrada da voz dos outros envolvidos no local e no percurso de elaboração do poema. No verso "foi considerado "Cidade das flores", é possível ainda observar que o agente da passiva não é explícito, indicando o isolamento de outras perspectivas. Evidencia-se, nessa citação de discurso alheio, a indicação de que houve pesquisa, de que houve trabalho a respeito do local 
e essa foi a forma que o enunciador escolheu para ceder à voz do outro um espaço encapsulado.

A presença da antonomásia (“cidade das flores”) não será recuperada pelas informações gerais que caracterizam o município em questão; não é dado da página inicial do site oficial da cidade ${ }^{40}$. Trata-se de uma voz institucionalizada, do hino de Suzano, como se observa em sua primeira estrofe: "Desperta a cidade das flores / que almeja um porvir triunfal / bandeira de todas as cores / no peito um só ideal.” A apresentação do hino parece entrar em consonância com o poema nesse aspecto, pois indica que houve a passagem de cidade das flores para cidade industrial: "O hino foi vencedor de um concurso municipal e foi estabelecido como símbolo oficial pela Lei $n^{\circ}$. 2347, de 30 de junho de 1989. Em sua marcha de cadência vibrante trata da formação do município e de suas características, entre a flor e a chaminé. Seu refrão marcial busca impulsionar a gente para a vitória diária do trabalho." (grifo nosso) ${ }^{41}$

Nesse aspecto, ao recuperar informações que veiculam institucionalmente na escola, o poema, nas primeiras estrofes, apresenta uma etapa que se institui como obrigatória em função das orientações dadas na oficina. Novamente como em outros poemas do Pólo São Paulo, o enunciador anuncia qual sua avaliação da tarefa. O ethos hesita entre a grandeza da tarefa e a honra que ela proporciona. Ao invés de retroceder para uma posição entre outros, deixando que falem por ele, o enunciador passa a descrever o lugar sempre tendo a si próprio como ponto de referência. Esse é o ponto de ruptura com os outros poemas e indica uma resistência quanto à manutenção da voz. O ethos se mantém até o fim do poema como potente para opinar ("Fico bravo falo até besteira"), avaliar ("tenho orgulho do meu lugar", "discutimos sobre os problemas do lugar") e planejar suas ações ("planejamos um campeonato legal", "minha turma gosta de agitar", "É lá que quero crescer") a serem desenvolvidas no lugar onde vive. Essa potência indica um dos primeiros movimentos em direção da posição autoral.

Embora seja ainda insuficiente, pois como observa Faraco (2005):

A linguagem não desdobrada (isto é, se a voz do escritor como pessoa permanece como tal) é, para Bakhtin, ingênua e inadequada para a autêntica criação estética. $O$ escritor é, então, a pessoa capaz de trabalhar numa linguagem enquanto permanece fora da linguagem.” (p. 40)

\footnotetext{
${ }^{40} \mathrm{http}: / /$ www.suzano.sp.gov.br

${ }^{41}$ Essas e outras informações sobre os símbolos de Suzano encontram-se em http://www.suzano.sp.gov.br/CN01/simbolos/simbolos_munic.asp, acesso em 06-06-2008.
} 
A imagem de si desenvolvida no poema indicia um quase desdobramento, não em relação a sua própria vida, pois a mudança se efetiva na assunção de uma posição que lhe permita desenvolver o sistema de valores em que o lugar não mais utópico, é simplesmente cenário para suas ações. Ora o lugar onde vive traz problemas (poeira, marginais, lixo...) para o enunciador, ora traz prazeres, mas quem ao fim permite que o prazer permaneça e o desconforto seja anulado é o grupo, como é possível verificar nas estrofes 7 e 8:

\begin{tabular}{|l|l|}
\hline 7 & 8 \\
Minha turma é animada & Lá tem um terreno baldio \\
Nos reunimos para conversar & Onde as pessoas jogam lixo \\
$\begin{array}{l}\text { Discutimos sobre os problemas } \\
\text { Que acontecem no lugar }\end{array}$ & Fizemos um mutirão \\
\hline
\end{tabular}

A primeira pessoa do plural, nesse caso, se configura como nós exclusivo, pois os moradores da cidade não estão nesse grupo. A autonomia do enunciador é a primeira etapa de uma tomada de posição que, aos poucos, poderá se refletir na elaboração da linguagem. No poema, ela se evidencia por uma auto-centração que se descola da imagem da cidade, ao denominá-la simplesmente com o hiperônimo "lugar". A cidade não assume metonimicamente os seus moradores. Não é personificada, nem adjetivada. Permanece como terra, campo, terreno baldio, rua esburacada...

A imagem projetada nos versos coloca o enunciador no centro das atenções, ao lado das pessoas que ele conhece e para as quais reserva um espaço - ao lado dele. As pessoas, embora sinceras, puras, amadas por esse enunciador não podem assumir sua voz e a cidade será uma memória da infância e um cenário para as suas realizações, daí o valor do título "Diversão e poeira", como a assinalar a coordenação das percepções do aluno-poeta. Sem se configurar como uma oposição de extremos, os sintagmas nominais indicam espaços alheios entre si, como apresentados ao longo dos versos.

A importância do título, nesse caso (embora seja possível estender a importância dessa atribuição a outros poemas), indica uma primeira posição axiológica do enunciador que sintetiza os movimentos centrais do poema. O caminho encontrado pelo aluno-poeta é a inversão do tema. De "Lugar onde vivo" chega-se a "eu vivo num lugar", com ênfase à presença do sujeito explícito. Seria essa uma possível saída para a questão autoral na proposta? Ressignificar o espaço a partir da visão do sujeito? 


\subsection{Desabafo}

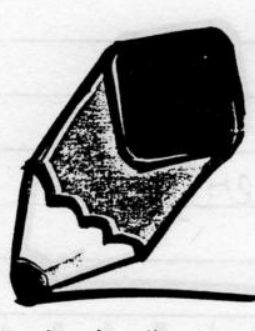

... Escrevendo Q. iurfun ${ }^{\circ} \mathrm{O}$ Suma iniciativa de fundacso uras sociai. Trulo: + desa

Com licerog muse urriges,

una histón, reu cuntar. de ure idade tas linda que a tedar wai incertar.

Eavara la wonto joratícip Tue en urea tempin de direra

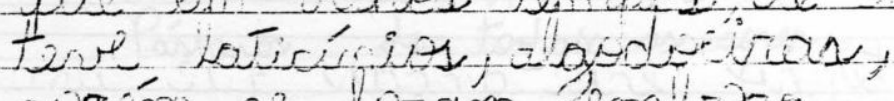

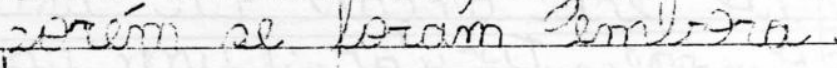

dón mution pities a chácaras elti ie decte buraz

os air cuidam ta rexa

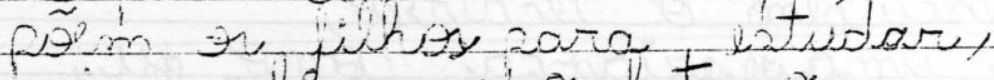
wir acibm que a futice nas rríp la susertude istá. mar tourdén temen poolteman muita gente a redlamar com a fpita de emprego Lem gerte aedindo ayuda ap presidente da nacão, Coitadios, estão à espera! 
de un adace de tâ.

us trogas tamifin sei-tem

aqui un minho istade,

sabtemes que la matsa,

con tamanila crueldade.

Muitas coiros ews obir,

overa en jó viri,

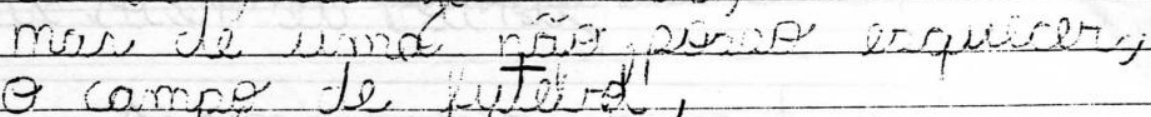

a camper de tytered'

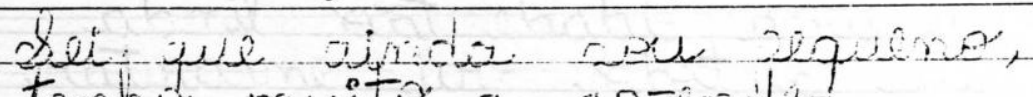

tenkis muite a aprender,

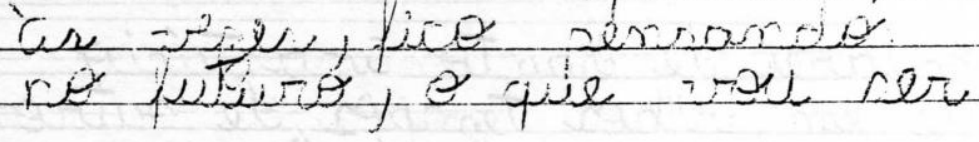

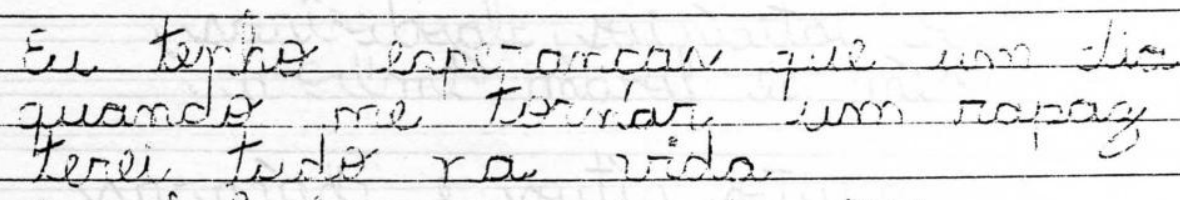
e vivisis rempie in pary.

Derculpem o teraitraip,

de ums ciarsa ómp ul,

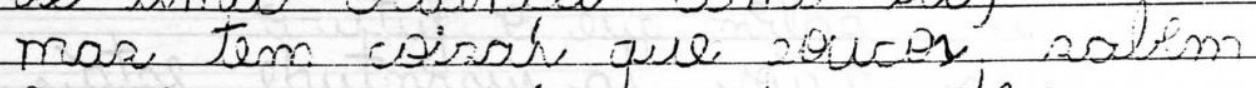
o que una risonita apricides. ollando o cofrimento, daquele que não vences. 


\begin{tabular}{|c|c|}
\hline Série & \\
\hline Masculino & \\
\hline $\begin{array}{l}\text { Desabafo } \\
\text { com licença meus amigos } \\
\text { uma história vou contar } \\
\text { de uma cidade tão linda } \\
\text { que a todos vai encantar } \\
\text { falarei de santo anastácio } \\
\text { que em velhos tempos de outrora, } \\
\text { teve laticínios, algodoeiras, } \\
\text { porém se foram embora. } \\
\text { há muitos sítios e chácaras } \\
\text { pertinho desse lugar, } \\
\text { os pais cuidam da roça, } \\
\text { põem os filhos para estudar, } \\
\text { pois sabem que o futuro } \\
\text { nas mãos da juventude está. } \\
\text { mas também temos problemas } \\
\text { muita gente a reclamar } \\
\text { com a falta de emprego } \\
\text { como poderão prosperar? } \\
\text { tem gente pedindo ajuda } \\
\text { ao presidente da nação, } \\
\text { coitados, estão à espera } \\
\text { de um pedaço de chão. }\end{array}$ & $\begin{array}{l}\text { As drogas também existem } \\
\text { Aqui em minha cidade, } \\
\text { Sabemos que ela mata, } \\
\text { Com tamanha crueldade. } \\
\text { Muitas coisas eu ouvi, } \\
\text { Outras, eu já vivi, } \\
\text { Mas de uma não posso esquecer, } \\
\text { O campo de futebol, } \\
\text { Nosso lugar de lazer. } \\
\text { Sei que ainda sou pequeno, } \\
\text { Tenho muito a aprender, } \\
\text { Às vezes, fico pensando } \\
\text { No futuro, o que vou ser? } \\
\text { Eu tenho esperanças que um dia, } \\
\text { Quando me tornar um rapaz } \\
\text { Terei tudo na vida } \\
\text { E viverei sempre em paz. } \\
\text { Desculpem o desabafo } \\
\text { De uma criança como eu, } \\
\text { Mas tem coisas que poucos sabem } \\
\text { O que uma criança aprendeu, } \\
\text { Olhando o sofrimento, } \\
\text { Daquele que não venceu. }\end{array}$ \\
\hline
\end{tabular}

Um dos relatos dos professores refere-se ao desenvolvimento dos poemas na escola em que foi escrito "Desabafo". Por essa razão, a análise se inicia com esses comentários, tentando, dessa maneira, trazer a sequência dos eventos.

A professora escreve o texto como uma narrativa cronologicamente organizada. Nos parágrafos iniciais, aponta as providências que tomou para que ocorresse a adesão à atividade: apresentou o Prêmio, sua estrutura e objetivo; então conversou com os alunos sobre as etapas, sobre o tema, daí vieram suas primeiras impressões ${ }^{42}$ :

Notei um total desinteresse sobre o assunto, fiquei um pouco desanimada, sem saber por onde começar.

Fiquei uns três dias falando com eles sobre o tema, falando sobre a nossa cidade, fazendo comparações, contando coisas que eles não conheciam e fui percebendo o interesse de alguns.

Depois dessa etapa, ela consegue o interesse de mais alunos, estabelecendo os “combinados" (uma orientação do kit) e, ainda sentindo que não estava atingindo a todos, ela toma uma decisão:

\footnotetext{
${ }^{42}$ Os relatos dos professores são cópias de material, em sua grande maioria, manuscritos, por essa razão segui a sequência de apresentação dos fatos, porque não poderia recorrer à paginação. As cópias dos relatos encontramse reproduzidas no anexo 2 .
} 
Para incentivá-los, convidei o professor Jairo, supervisor na Diretoria de Ensino, que é um poeta. Ele atendeu-me prontamente, veio até minha sala e passou horas, conversando com os alunos e declamando poesias de sua autoria.

Observei que as crianças gostaram muito.

Aproveitei a visita do professor Jairo para tirar dúvidas e aprimorar meus conhecimentos.

A intervenção, justificada pela necessidade dos alunos e da professora, é importante principalmente por causa de ambientes de pouco letramento ("poucos são os pais que cursaram até a $4^{a}$ série e isso dificultou uma adesão maior", a professora afirma em outro trecho do relato).

Além das condições dos ambientes externos que envolvem a sala de aula, como a pouca familiaridade dos pais com a cultura letrada, a professora indica, com a explicitação de suas "dúvidas" e com a necessidade de "aprimorar seus conhecimentos", que, mesmo na sala de aula, essa insuficiência pode aflorar. Não se trata de algo totalizante (não saber nada), porém a forma de abordar o poema e a sequência didática proposta se configuram em abordagens que exigem do professor outras respostas, além daquelas instituídas a partir do livro didático. Nesse caso, a professora apresenta um ethos preocupado, cioso e aberto a mudanças na busca de um saber que se projeta na ação e dela deriva como construção a partir das práticas desenvolvidas no espaço da sala de aula. A proposta do Prêmio alcança nesse tipo de procedimento alguns de seus objetivos, um dos mais difíceis: a capacitação do professor por meio de um fazer que precisa se constituir diante dos alunos, com os alunos, uma vez que ele está sempre em formação.

A busca pela capacitação pode ter indicado aos alunos, sem que a professora percebesse a extensão desse processo, que o Prêmio também era uma oportunidade para que ela aprendesse, dividindo a posição de poder em sala com outros sujeitos. Esse deslocamento de lugares e papéis (não a inversão) muitas vezes é o gatilho para o estabelecimento de uma nova representação do professor possibilitando ao aluno a busca de lugares para si, pois perceber que o conhecimento se faz em um percurso "sem fim" gera uma empatia necessária para a assunção de posições assemelhadas entre professor e aluno, equilibrando as forças desiguais que se distribuem no espaço da sala de aula.

Em virtude da explicitação de posicionamentos diversos em sala de aula, com a presença física de outros sujeitos envolvidos com o gênero poético, em comparação com os percursos de elaboração dos outros poemas, é possível observar que a representação dos elementos composicionais como base para a elaboração do poema (recorrentes entre os 
poemas do Pólo São Paulo) são resultado da proposta da sequência didática do Prêmio, adquirindo valor estrutural e discursivo para esses alunos.

Assim o traço comum a todos os poemas até aqui analisados, a manutenção da rima como elemento coesivo também está presente no poema "Desabafo". Ela ocorre muitas vezes em versos que estão com o ritmo da prosa, sendo a única ligação com o gênero poético. Os outros elementos também presentes, como a aliteração e a assonância ${ }^{43}$ (as letras maiúsculas nas duas primeiras estrofes - transcritas na tabela abaixo - indicam os constantes sons nasais presentes), apresentam a mesma oscilação, não apontando para a presença que indicie o tema ou um ritmo próprio espelhado no objeto. São ainda tentativas que aos poucos parecem traçar uma linha quase imperceptível da postura do enunciador - assemelhando-se à voz física projetada na sonoridade que indica movimentos de euforia e disforia no poema.

\begin{tabular}{|c|c|}
\hline $\begin{array}{l}1 \\
\text { Com licENça meus aMigos } \\
\text { UMa história vou cONtar } \\
\text { De uMa cidade tÃO IINda } \\
\text { Que a todos vai ENcANtar }\end{array}$ & $\begin{array}{l}2 \\
\text { Falarei de SANto Anastácio } \\
\text { Que EM velhos tEMpos de outrora, } \\
\text { Teve laticínios, algodoeiras, } \\
\text { PorÉM se forAM EMbora. }\end{array}$ \\
\hline
\end{tabular}

No caso das primeiras estrofes (e mais discretamente nas demais), a assonância das nasais indicia o caráter do desabafo, uma voz melancólica, como afirma Martins: "a ressonância nasal torna as vogais aptas a exprimir sons velados, prolongados (zumzum, zumbido, ron-ron, gongo, trim-trim, tanger, planger) e a sugerir distância, lentidão, moleza, melancolia (longe, longínquo, distante bambo, brando, manso, langue, pranto, lamento)” (1989, p. 32-33) (grifo nosso). O que ocorre, depois, é a atenuação da presença das nasais pelo surgimento e manutenção das rimas em "ar" (muitas vezes assumindo o som /a/, com o apagamento da desinência da forma nominal do verbo, como ocorre na fala), que deslocam as sugestões aos sentidos para "idéias de claridade, brancura, amplidão, alegria etc." (MARTINS, 1998, p. 30).

As rimas em "a" são consoantes nas estrofes 1, 3, 4, 9 em função dos verbos da primeira conjugação no infinitivo. Na estrofe 6 , a rima se mantém em outra forma, a toante (cidAde, mAta e claridAde). No entanto, retomando o tom inicial do poema, a presença do "a" se reduz a partir da estrofe 7. $\mathrm{Na} 8$, retorna a rima em "e" (esquecer e lazer) dividindo o espaço dos versos com a rima em i (ouvi, vivi). Há um deslocamento de impressões que antes

\footnotetext{
${ }^{43}$ cf. para o estudo dos sons expressivos MARTINS, 1989; CANDIDO, 2006
} 
se ligavam à claridade, à abertura, para impressões relacionadas a um estreitamento, cujo ápice ocorre na estrofe 10 com as rimas em "eu".

Dentro do movimento temático do poema, essa mudança que retoma a proposição inicial do desabafo é o elemento composicional que estabelece os laços coesivos remetendo à unidade temática. Também indica que o aluno-poeta ainda não consegue trabalhar com vários elementos composicionais ao mesmo tempo, mas se posiciona ao lado dessa rede, criando pseudo-regularidades, ao compor versos que, embora não sejam regulares, se situam em áreas próximas; são aproximações que, por vezes, podem confundir os ouvidos do leitor que os regulariza baseado no trabalho sonoro desenvolvido no poema.

A estrutura composicional parece sustentar a relação entre as vozes, como pano de fundo. Em "Desabafo", o enunciador do texto se dirige ao leitor de forma explícita, indicando de onde fala e por que fala.

\section{Com licença meus amigos \\ Uma história vou contar \\ De uma cidade tão linda \\ Que a todos vai encantar}

De maneira bastante sensata, ele mostra mais de um aspecto da cidade - suas belezas e seus problemas. Todas as informações levantadas nas oficinas que se referem ao conteúdo estão presentes; há um grande apelo para uma aderência à realidade, com pouco espaço para o que Bakhtin identifica como autor criador, uma posição refratada e refratante, que, segundo Faraco (2005), poderia ser descrita como "refratada porque se trata de uma posição axiológica conforme recortada pelo viés valorativo do autor-pessoa, e refratante porque é a partir dela que se recorta e se reordena (sic) esteticamente os eventos da vida" (p. 39).

Ao fim do poema, o enunciador revela vozes que se aliam à dele, formando um ethos coletivo que assume a posição de um indivíduo, correspondendo ao desabafo de tantos que o precederam e com os quais convive. Essa conjunção de posições é bastante comum na questão do ethos, como observa Amossy, embora não se refira especificamente ao discurso literário:

parece, portanto, que a eficácia da palavra não é nem puramente exterior (institucional) nem puramente interna (linguageira). (....) A passagem do sujeito falante como ser empírico ou "ser no mundo" para o locutor como pura instância de discurso se efetua por uma série de mediações. (2005, p. 136)

Como se trata de aluno da $4^{\mathrm{a}}$ série ( $5^{\mathrm{o}}$ ano), a menção a essa imagem de enunciador que, ao se declarar inepto, apto se mostra a uma reflexão, pode ter como efeito a captação do 
leitor pela humildade (tópos recorrente na poesia de cordel). O poema não apresenta muitos recursos linguísticos da poesia, além dos formais, mas a identificação com a poesia popular faz com que outros cordéis soem ao lado dele, ampliando, sem que ele tenha consciência, o poder de seu texto. Trata-se da intertextualidade, em que vozes se alinham, e outros ethé podem ser entrevistos aqui e ali. ${ }^{44}$

\begin{tabular}{|c|c|c|}
\hline \\
\hline Sei que ainda sou pequeno, & Eu tenho esperancas que um dia, & Desculpem o desabafo \\
\hline Tenho muito a aprender, & Quando me tornar um rapaz & De uma criança como eu, \\
\hline Às vezes, fico pensando & Terei tudo na vida & Mas tem coisas que poucos sabem \\
\hline No futuro, o que vou ser? & E viverei sempre em paz. & $\begin{array}{l}\text { O que uma criança aprendeu, } \\
\text { Olhando o sofrimento, } \\
\text { Daquele que não venceu. }\end{array}$ \\
\hline
\end{tabular}

No poema "Desabafo", a posição autoral se desenvolve no ethos do porta-voz das informações, ou seja, a forma como o enunciador encadeia os fatos relativos à cidade. Essa função está intrinsecamente ligada à origem do cordel em comunidades com pouco letramento em que a voz do poeta trazia notícias de longe e permitia a circulação e legitimação de fatos e atores sociais. Dos vários gêneros, o cordel parece ter estimulado de forma mais efetiva os poemas, como "Desabafo", e permitido igual posicionamento (para grupos em que houve tal identificação), uma vez que, numa estrutura composicional mais conhecida e com variações formais menores, tem-se a impressão de domínio. Essa legitimação, muitas vezes, leva o aluno a colocar sua voz ao lado das outras e não se submeter a elas.

O tema da crítica cidadã ao local onde se vive aparece no poema como retomada de temática bastante frequente no cordel. Esse olhar crítico, que se posiciona como parte e não como observador, surge como ethos responsável e inconformado, crítico e de denúncia. A multifacetada visão do local é também a busca plural de lugares não para viver, lugares de onde enunciar. O enunciador do poema põe em questão a visão daquele que lê: "Mas tem coisas que poucos sabem". O que sugere um alerta para o leitor: de que lado você está?

Por fim, o enunciador se posiciona de duas formas, num movimento assemelhado a de outros poemas já analisados: ao tratar dos aspectos contextuais imediatos e históricos, surge um nós ("temos problemas"; "sabemos que ela mata") que desaparece à medida que ele encontra um lugar de onde enunciar. Trata-se de um posicionamento questionador de uma estratégia aprovada socialmente: aprender com a experiência dos mais velhos, que indica a

\footnotetext{
44 Trata-se de ethos prévio que aparece no texto evocado pela estrutura formal, tal como aparece em MAINGUENEAU, 2006.
} 
imagem da "criança" ("sou pequeno") como suficiente para entender, para enunciar, para indicar valores, porque a situação assim o exige. É tempo de crescer em Santo Anastácio! 


\subsection{A minha cidade}

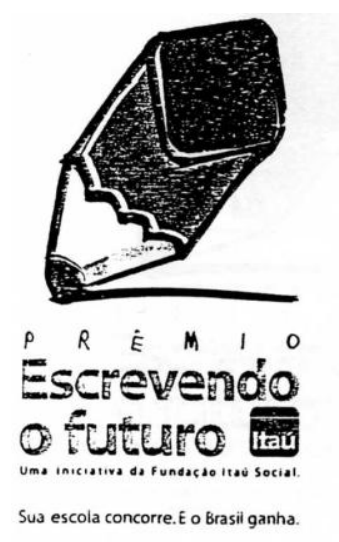

Titulo: le Minlva cidade

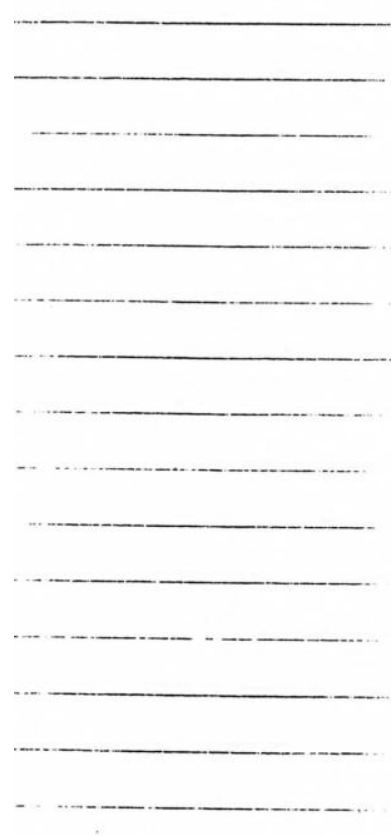

Opono dessa sidade

Vive sempre apressado

dolmonstrando a sua gana

has ruas cheias e onillus lotados

Onde quer que ougente rpó

Iem sempre fila e multida

Guem nav conhece fice assustado

com tants agitapa

mas como nada é pefleito

Semes problemas sem solupãa

conor, a fome, a monadia, a violencia

fambim a saúde e a educscãa

eigona vamos fala Das coisas bocas da minha cidade Em qualques thora e lugar I lm diversoo pra toda idode 

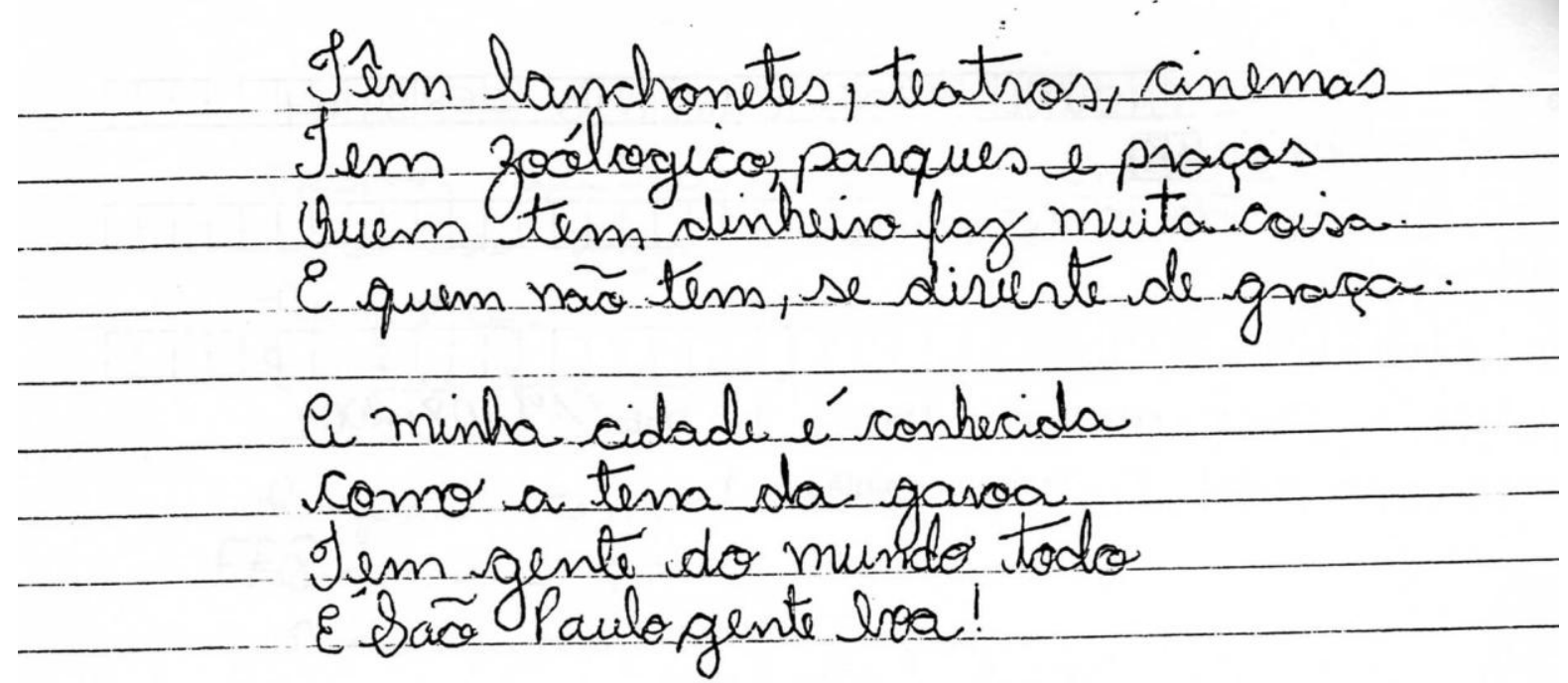

Essar cidade nã pána

Esta ligada 24 honas.

mas fo lston indo domir...

\begin{tabular}{|l|l|}
\hline Série & $4^{\mathrm{a}}$ \\
\hline Sexo & Feminino \\
\hline
\end{tabular}

A minha cidade

A minha cidade não tem Cristo Redentor (13)

Mas também é abençoada (8)

Por São Paulo, o protetor (7)

O povo dessa cidade (7)

Vive sempre apressado (7)

Demonstrando a sua gana (7)

Nas ruas cheias e ônibus lotados (11)

Onde quer que a gente vá (7)

Tem sempre fila e multidão (8)

Quem não conhece fica assustado (10)

Com tanta agitação (6)

Mas como nada é perfeito (8)

Temos problemas sem solução (9)

Como, a fome, a moradia, a violência (11)

Também a saúde e a educação (9)
Agora vamos falar (7)

Das coisas boas da minha cidade (10)

Em qualquer hora e lugar (8)

Tem diversão pra toda idade. (8)

Têm lanchonetes, teatros, cinemas (11)

Tem zoológico, parques e praças (10)

Quem tem dinheiro faz muita coisa. (9)

E quem não tem se diverte de graça. (10)

A minha cidade é conhecida (10)

Como a terra da garoa (7)

Tem gente do mundo todo (7)

É São Paulo, gente boa! (7)

Essa cidade não pára (7)

Está ligada 24 horas (10)

Mas já estou indo dormir... (8) 
No poema "A minha cidade", os versos iniciais já apontam para o processo predominante: a intertextualidade. O parâmetro colocado pelo enunciador para tratar do lugar é outra cidade, Rio de Janeiro, também influente e importante como São Paulo, mas aclamada como "cidade maravilhosa" que tem como símbolo a estátua do Cristo Redentor. Assim o enunciador começa seu poema anunciando a falta intrínseca de sua cidade e uma forma de compensá-la, marcada por "também", indiciando uma pressuposição: a noção de que o Cristo abençoa o Rio e de que a cidade de São Paulo precisa igualmente dessa benção que obtém de São Paulo.

O uso da intertextualidade aponta a adesão à canção "Cidade Maravilhosa" forma de se tratar o lugar onde se vive, e indica, ao mesmo tempo, forte oposição a esse enunciado, como a afirmar que ele é verdadeiro e potente, não descrevendo, porém, o único lugar digno dessas honrarias. Há aqui um tratamento diferenciado às vozes que são colocadas no poema. A algumas, o enunciador se opõe; outras, acolhe para que a identidade do lugar em que se vive surja fortalecido. A aceitação das outras vozes presentes nos poemas resulta, nesse caso, de uma estratégia argumentativa, em que o aluno, embora reconheça a legitimidade de todas essas vozes, escolhe o que lhe parece mais relevante para ressaltar as qualidades do seu lugar, afastando as outras para espaços argumentativos periféricos no poema como o primeiro verso, para depois refirmar a potência: "mas também é abençoada / por São Paulo, o protetor." É um modo singular de satisfazer ao critério de avaliação do prêmio se comparado àqueles presentes nos demais poemas analisados anteriormente, em que o apagamento de vozes exteriores ao espaço descrito se constitui como forma de sublinhar o caráter absoluto do lugar num processo textual que se assemelha ao morfológico da adjetivação superlativa sintética.

A posição do enunciador ao longo do poema reflete esse movimento argumentativo de refutação e de adesão às vozes alheias à dele. Na primeira estrofe, o lugar é "minha cidade", como a demonstrar a posição dele. Na segunda estrofe, o foco é "o povo dessa cidade", um afastamento que pode indicar a não adesão ao modo como grande parte das pessoas vive, ou a negar a representação oficial. Na terceira estrofe, surge uma forma de indicar o coletivo "a gente", que é confirmada pela primeira pessoa do plural, "temos" ( 4 a estrofe) e "vamos falar"

\footnotetext{
45 "Cidade Maravilhosa/ cheia de encantos mil/ Cidade maravilhosa/ coração do meu Brasil" são os versos iniciais dessa canção do Carnaval de 1935 por André Filho, originalmente gravada, em 1934, por Aurora Miranda e pelo próprio André Filho. Hoje, é considerada o hino da Cidade do Rio de Janeiro. Fonte: http://www.geocities.com/locbelvedere/Musicas/Cidademaravilhosa.htm, acesso em 10-10-2009.
} 
( $5^{\mathrm{a}}$ estrofe). $\mathrm{Na} 6^{\mathrm{a}}$ estrofe, porém, ao indicar que, em São Paulo, o que prevalece é o dinheiro, a aluna-poetisa utiliza o pronome "quem" - um afastamento total. $\mathrm{Na} 7^{\mathrm{a}}$ estrofe, ela volta à posição inicial "a minha cidade"; para em seguida, na $8^{\mathrm{a}}$ estrofe, revelar pela oposição ao modus operandi da cidade (essa cidade não para/ está ligada 24 horas), um modo de ser dela mesma (mas já estou indo dormir).

Ao trabalhar com outros enunciados, a aluna-poetisa escolhe travar diálogos com outros textos-símbolo de São Paulo, também da esfera do poético. Esses textos se desdobram em formas não-marcadas como a alusão à canção de Alvarenga e Ranchinho, "Êh, São Paulo $^{46 "}$ que trazem o passado de uma cidade ainda governável e com mais atributos positivos. No poema, a imagem da cidade do passado é fundida, pela metonímia, a uma nova caracterização de São Paulo - o aspecto positivo da cidade são os seus moradores: "É São Paulo, gente boa!". A transposição é feita por meio da rima "garoa" e "boa" 47 , que consistiria na projeção do eixo paradigmático no sintagmático, como formulou Jakobson (1969), ou ainda no acoplamento como descreve Levin (1975). O acoplamento se constitui em equivalências do tipo I de posição e do tipo II de caráter extralinguístico. Embora Levin não tivesse formulado o acoplamento para questões discursivas; os de tipo II projetam equivalências entre palavras ou sintagmas, que carregam para dentro do texto enunciados. Seria equivalente às formas não marcadas para os poemas, em que as alusões, a ironia, o pastiche, trariam pela estrutura ou pelo arranjo do léxico a outra voz, garantindo o diálogo entre elas por essa equivalência.

A aluna-poetisa trabalha nessa estrofe com elementos dos gêneros poéticos que abrem espaço para a legitimação do poema por meio da memória do gênero naquele que lê semelhanças que podem confundir os ouvidos do leitor e indicam não o domínio dos elementos composicionais formais dessa aluna, mas a consciência em desenvolvimento de como se articulam esses elementos. Esse vir a ser das convenções poéticas, nesse caso, faz parte da representação do gênero para esse enunciador, percepções inexatas, que, no entanto, ajudam-nos a questionar representações baseadas em convenções, que, como afirma Levin, são insuficientes: “O uso dessas convenções estritamente literárias serve para infundir, a um

\footnotetext{
${ }^{46}$ Êh, São Paulo / Êh São Paulo / São Paulo da garoa / São Paulo que terra boa. Esses são os versos iniciais da canção de Alvarenga e Ranchinho conhecidos sempre que o tema é São Paulo. Canção disponível em http://cifrantiga3.blogspot.com/2006/08/h-so-paulo.html acesso em 06-06-2008.

${ }^{47}$ Os demais elementos da poesia não são significativos para a construção do diálogo entre os textos que a aluna propõe.
} 
trecho de linguagem, uma marca característica; esses traços, porém, não conferem, por si sós, a um poema, o sentido de unidade que ele suscita." (1975, p. 102)

$\mathrm{O}$ que poderia conferir essa unidade? O trabalho com a linguagem e com as vozes parece ser o caminho para alcançar o poético, visto que os elementos convencionais não são suficientes. "Para Bakhtin", segundo a leitura de Tezza (2006, p. 215), “o poético é a expressão completa de um olhar sobre o mundo que chama a si a responsabilidade total de suas palavras". Trata-se então de desenvolver essa tomada de posição. Seria possível nessa idade? Quais critérios poderiam ser usados? A originalidade permaneceria, nesse caso?

O enunciador ainda vai adiante ao trazer mais uma alusão ao poema, pois sua última estrofe dialoga com a Sinfonia Paulistana, cujos versos são: "São Paulo que amanhece trabalhando / São Paulo que não pode adormecer / Porque durante a noite o paulista vai pensando / nas coisas que de dia vai fazer." ${ }^{, 4}$ Mesclados os tempos e as vontades, a alunapoetisa vai dormir sabendo que a cidade ficará alerta; contando talvez com o fato de que sua voz de menina pode, no espaço do poema, parar a cidade com o poder de seu sono. Essa potência ensaia, assim, a assunção de uma responsabilidade marcada pelo questionamento resultante da ironia que se instaurou pelo caráter inesperado da sua ação: o enunciador parece declarar sua potência ao negar aquilo que estava pressuposto.

O questionamento, nesse caso, por meio da ação contrária, permite que as outras vozes fiquem circunscritas ao espaço público, pois, ao tomar a decisão de dormir, o enunciador indica que, no espaço privado, quem decide é ele. Se essa ação vai mudar algo, não é possível saber, porém o uso da brincadeira de caráter antitético (a cidade não dorme, mas eu vou dormir) indica que o lúdico pode ser uma saída para a refração autoral. Encontrar uma posição de onde enunciar; antropofagizar as vozes alheias ou questioná-las se configura até esse momento como forma eficaz para a aluna embuir-se do papel de poeta. Qual o espaço para esses movimentos nas oficinas?

\footnotetext{
48 A letra de Sinfonia Paulistana, cuja autoria é de Billy Blanco, apresenta vários metros e ritmos como seria esperado numa Sinfonia e pode ser lida em http://www.mpbnet.com.br/musicos/billy.blanco/letras/sinfonia_paulistana.htm acesso em 06-06-2008.
} 


\subsection{Bariri, bem te vi}

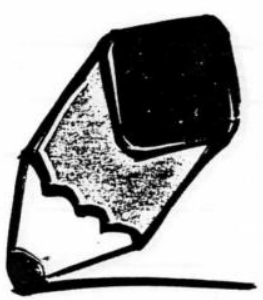

P $R \quad \dot{E} \quad M \quad 1 \quad 0$ EsG: a Antwo Eaú

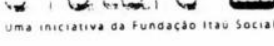

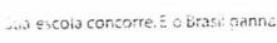

Título: Dariw, Dem te vi

Possarinto nal janila

Essar is Low de chegar?

Cindar é seds, os sol, es escondel

Pov quie vens me acordan?

Minininas, nas te assuntes Lim apenass te contaw Irota-res de uma caurar "urta: Whistionio disia lugan!

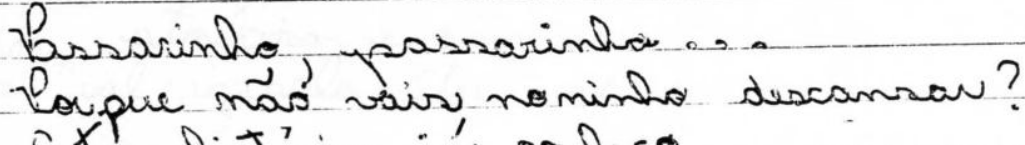

Exts história ifá sonblizs

gá canseiv de istudan!

menininds meninimbo.

Esar história é riva!

ños podes nos livioss encortuan

Givezimbar, aver vizimbal lov que na paran de mu importunar?

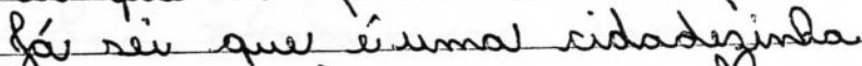
Deis de belemass paras abran

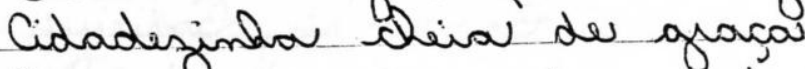
Com rews parawes, suas prougast... Hó ánoues, beijar-floves, igasminss É cercadar de jandins. 
105

Esqueceste, meninimbo

De tew pove, twa gente

hompitalina es de bos fí

Esquaceste das comidas

Vizzas, docess es epicolí.

Pasraimble, passacinho

Parral rindo, passa lindo

na janils do mew low

E nas páras de cantarelaw:

"Sanim Baini, Sariri

Bem-te or lem - te - vi, bem - te - vi!"

minuminas sondento Yem em minasas asas visjow Yim wer a lage, a regeren $\varepsilon$ obomem a piscan. nà tumbas medo, sorotundo, "Ćguars barulbentas" é so a nome Sous Bami nas é cichenta

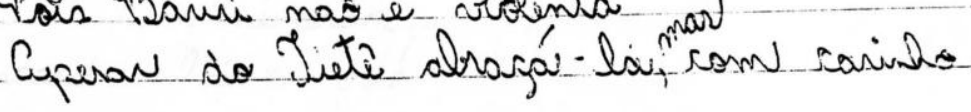

fassanimbs pasravinho

há quanté tempo estow al te ouviry, fó contaste de tudo um pouquiniro... Posso roltar al dormin?

menininho menuminho

Mais bistólias tendo em mew ninbo sober esse trangiilo lugar imborar pequeniminbo

É nesser lav que queno sempere cantav:

Barini. Bar ri-ri, Baririvi. .

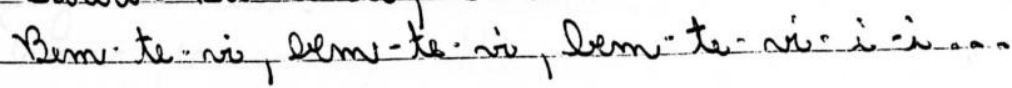




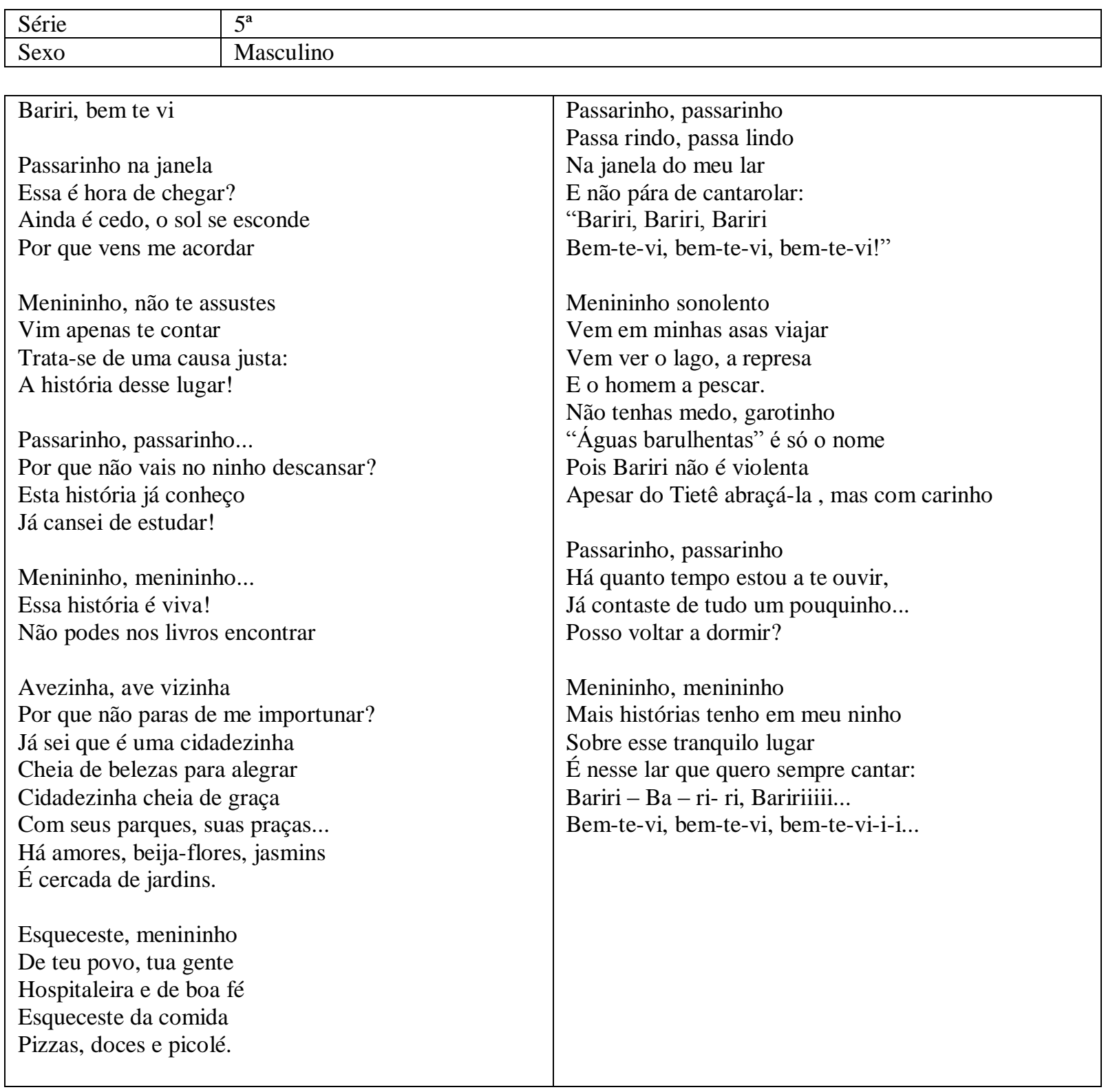

Nos relatos dos professores, há um sobre o processo de elaboração dos poemas dentro da sequência didática proposta pelas orientações do Prêmio referente ao poema "Bariri, bem te vi”. A professora, em suas anotações, relata já existir na escola uma infra-estrutura mais adequada às exigências do concurso e, por isso, conseguiu envolver outros professores que se apresentaram no Sarau previsto para a troca de experiências e textos. A experiência positiva não promoveu apenas a integração, devolvendo o poema para outros espaços além da sala de aula; permitiu também que os alunos testassem os poemas em voz alta. Escondida no ato de ler com os olhos ${ }^{49}$, a voz não pode revelar traços que impedem o poema de alcançar a sua

\footnotetext{
${ }^{49}$ Candido (2006) apresenta as duas correntes sobre a leitura de poesia. A primeira negaria o caráter sonoro da poesia nos nossos dias; a outra afirma: "mas certos psicólogos e foneticistas sustentam que a leitura é acompanhada de um esboço de fonação (ação ideo-motora) e de audição, de tal modo que nós representamos o
} 
unidade. Nessa leitura compartilhada, quando se desdobra na posição de leitor, o aluno-poeta ocupa também a posição de intérprete, em sua performance. A leitura em voz alta permite isso porque "você verificará quando ler o poema em voz alta, que o próprio ato de pronunciar as palavras obriga-o a entendê-las melhor. Não poderá passar por cima de uma frase ou de um verso mal compreendido com tanta facilidade, se estiver lendo em voz alta." (ADLER; DOREN, apud PINHEIRO, 1995, p. 33). O aluno também não conseguirá sustentar um verso sem ritmo, se tentar pronunciá-lo nesse tipo de leitura. Além disso, o Sarau pode revelar a importância de diferentes leituras para um mesmo poema; afere-se dessa forma a unidade, a interpretação de cada um e a pluralidade de sentidos propiciada pelos gêneros poéticos.

Continuando em seu relato, a professora se mostra sensível às condições do grupo com o qual trabalha:

A pouca sensibilidade da criança habituada, desde cedo, a ver a vida e o mundo apenas pela perspectiva dos adultos (dura, sofrida) torna-a, muitas vezes, fria, pouco emotiva e a impossibilita de recriar o mundo através da palavra.

Os textos são, na maioria, pobres de recursos e é comum ouvi-los dizer: "Eu não sei fazer, eu não sou poeta!"”

Seu olhar atento identifica as representações de poesia que estão circulando pela sala de aula. Há duas mais frequentes: a da falta (eles não são suficientes para assumirem a posição de $\operatorname{poetas}^{50}$ ) e a das convenções poéticas como o único critério para a constituição do texto poético (poesia tem de ser rimada). Identificar e intervir nessas representações é essencial para o sucesso dos textos, além daquele selecionado para o Prêmio, como ela mesma afirma no relato.

Outro ponto considerado foi a participação na oficina "Conhecendo a poesia popular", em que os alunos entraram em contato com Patativa do Assaré e concluíram: "Esse poeta fala na nossa língua”. A professora avalia a oficina 8: “(os alunos) Adoraram fazer acrósticos e depois pedir para o colega ler para classe. Uma forma que encontraram de revelarem-se sem ter que se "aparecer". Ah, os acrósticos que montaram dos professores foram o máximo e revelaram todo o conceito que estabelecem conosco!"

As imagens resultantes, representações dos professores, são aspectos discursivos da escrita do poema e permitem a exposição dos valores dos alunos, o que facilita a assunção autoral, a responsabilização pela palavra. (TEZZA, 2006)

efeito visado." (p. 41). Dessa forma, a leitura em voz alta explicitaria o esboço de fonação que, aos poucos , pode ser incorporado na elaboração do poema.

50 Sobre essa questão, Cristovão Tezza (2006) analisa como a autoridade da voz do poeta encontra-se em crise nos tempos atuais. 
A partir dessa identificação, é possível entender o processo de criação presente no poema escolhido. Em "Bariri, bem-te-vi", o enunciador não se dirige ao leitor. Trata-se de um longo diálogo, com algumas características de desafio (indicada em azul), comum a algumas modalidades do repente e ao universo da poesia popular, ${ }^{51}$, que apresenta uma condensação de elementos poéticos formais e temáticos.

Um dos traços utilizados no poema (coincide com a descrição de Ivanildo Vilanova, cf. nota 53) é o uso da $2^{a}$ pessoa do singular (assinalado em verde) que reforça a ligação com a poesia popular, com raízes em outros tempos, em outras variantes. A utilização correta da $2^{\text {a }}$ pessoa do singular e do plural, no entanto, é traço da escolarização e de poetas com experiências em diversas variantes e registros linguísticos.

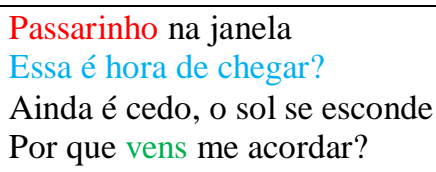

Menininho, não te assustes

Vim apenas te contar

Trata-se de uma causa justa:

A história desse lugar!
Passarinho, passarinho...

Por que não vais no ninho descansar?

Esta história já conheço

Já cansei de estudar!

Com essa regularidade de tratamento, o diálogo entre o "passarinho" e o "menininho" segue até o fim, estrofe a estrofe, identificando as tensões entre o discurso institucionalizado, representado pelo passarinho, e o discurso do jovem, representado pelo menininho, que tem a informação, mas parece não se importar com ela. Trata-se de um recurso bastante sofisticado em que o enunciador, ao colocar outros dois para concretizarem a tarefa de falar sobre o lugar, indica a busca da atenção de dois grupos de sua realidade, duas posições colocadas em conflito. Essa presença dupla de ethé demonstra a construção de um jogo que envolve o viés valorativo do autor-pessoa e a reordenação estética da realidade. Poderia ser interferência da professora? Ou seria fruto da troca e da circulação do poema que possbilitaram esse amadurecimento?

A rede de significação se estende a outros recursos no poema. No metro, há uma tendência à regularidade construída como nos outros casos com metros próximos entre si. São eneassílabos e decassílabos; redondilha maior e octassílabos. Desses, a redondilha maior

\footnotetext{
51 "Desafio é logo o primeiro verso dum violeiro para o outro, quando o convoca para a cantoria. Mas desafio é somente um dos muitos gêneros do repente. Eu, particularmente, o detesto. Acho uma besteira, porque é muito pobre. A não ser quando é o inverso, um desafio pra falar bem do sujeito. No repente, o violeiro tem de pegar a deixa do outro, se preocupar com a rima, a métrica, o bom português. Aí ele irrita os outros. O repente não confunde "tu" com vós". Ele não assassina a língua. Pelo pouco que faça já é muito." Trecho da entrevista de Ivanildo Vilanova a Miguel de Almeida, In Folha de São Paulo, 30-05-1982. Disponível em http://almanaque.folha.uol.com.br/musicapop1.htm Acesso em 07-06-2008.
} 
aparece com maior frequência nos poemas lidos e oferecidos aos alunos, razão provável da predileção demonstrada no texto e presente muitas vezes nos poemas de cordel.

O poema se constrói em níveis que mantêm a tensão coesiva como a pontuação. Os pontos interrogativos criam o ritmo prosódico típico da conversação, ao simular o par pergunta - resposta; ao lado das reticências que provocam no leitor a busca de entonações que sustentem o tipo de diálogo desenvolvido pelo passarinho e pelo menininho.

No nível sonoro, o esquema de rimas situa o poema no universo da poesia popular uma vez que as rimas são pobres (em geral, verbos da primeira conjugação no infinitivo e substantivos) e consoantes. A ocorrência de rimas em "ar", mais frequente, confere ao poema um tom aberto e mais leve. Ainda quanto às rimas, existem as internas, presentes nas palavras centrais do poema: "passarinho", "cidadezinha" e "menininho". A coincidência entre elas representa a razão de ser do texto e do tema, refigurado na tríade: autor, herói e leitor (BAKHTIN, 2003).

\begin{tabular}{|l|l}
\hline Passarinho, passarinho & Menininho, menininho \\
Há quanto tempo estou a te ouvir, & Mais histórias tenho em meu ninho \\
Já contaste de tudo um pouquinho... & Sobre esse tranquilo lugar \\
Posso voltar a dormir? & É nesse lar que quero sempre cantar: \\
\hline
\end{tabular}

O ponto de conflito entre os dois se refere ao grau de importância que se dá ao lugar onde se vive. $\mathrm{O}$ menino responde ao passarinho o que ele quer saber com o intuito de voltar a dormir. Não será essa muitas vezes a opção do aluno em relação aos projetos dos professores ou de outras instituições? Cumprir a obrigação, dizer o que o outro deseja ouvir para voltar à zona de conforto. O traço levemente irônico dessa situação se encontra no vocativo empregado para o passarinho: "avezinha, ave vizinha" e "passarinho, passarinho / passa rindo, passa lindo". A quebra das palavras indica certo repertório de leitura no gênero e a presença do lúdico, que novamente surge como forma de o enunciador mais jovem (identificado com o aluno) encontrar espaço para suas inquietações, vontades, desejos.

O passarinho, por sua vez, chama-o sempre de menininho - forma derivada no diminutivo. Sandmann afirma que os morfemas derivacionais de grau têm grande produtividade na língua portuguesa e são "portadores de conteúdo diversos. Diminutivos podem expressar simpatia por um objeto [...]. Outras vezes objetivam suavizar uma situação desagradável [...]. O aspecto meliorativo ou pejorativo muitas vezes só se depreende do contexto ou da situação, o que faz parte do lado pragmático da linguagem [...]." (SANDMANN, 1989, p. 40). No caso do poema, o diminutivo em menininho indica, além da 
pouca idade (menino já indicaria ser bastante jovem), inexperiência, apresentando a imagem que faz do outro, elemento constitutivo para o tratamento dado às informações que apresenta.

No diálogo, são projetadas duas posições típicas da esfera escolar envolvidas constantemente na negociação da produção do saber: a do professor e a do aluno. A primeira convocando sempiternamente para o trabalho, para a busca do saber, para o envolvimento com os temas trabalhados, nivelando os temas ao mesmo grau de importância. A segunda resistindo à investida da posição legitimada pelo espaço escolar, questionando a validade desses temas e saberes diante das necessidades individuais.

Como se observa, nenhum dos dois deixa sua posição. Não há a típica conciliação, ambos representam algo que, na realidade, se configura como a disputa entre o "velho" e o "novo". O que há em comum entre eles: a mesma maestria no gênero poético de feição popular. Ambos os ethé, embora com idades diversas, têm em comum um saber: a história, caracterizada ora de forma positiva em duas ocorrências dentro do texto: "a história desse lugar!" (verso 8); “essa história é viva! / Não podes nos livros encontrar” (verso 14); ora apresentada como saber já adquirido ao qual não é necessário voltar: "Essa história já conheço/ Já cansei de estudar" (versos 11 e 12). Esse embate entre os dois enunciadores sobre a história da cidade reforça a posição autoral na releitura de um gênero de imbricamentos (música e poesia) como o repente, indicando que embora não exista uma linguagem poética por si só, existem estruturas que podem ser caracterizada como poéticas, cuja elaboração resulta da confluência dos níveis (ou dos acoplamentos, cf. p. 96). 


\subsection{Conquista}

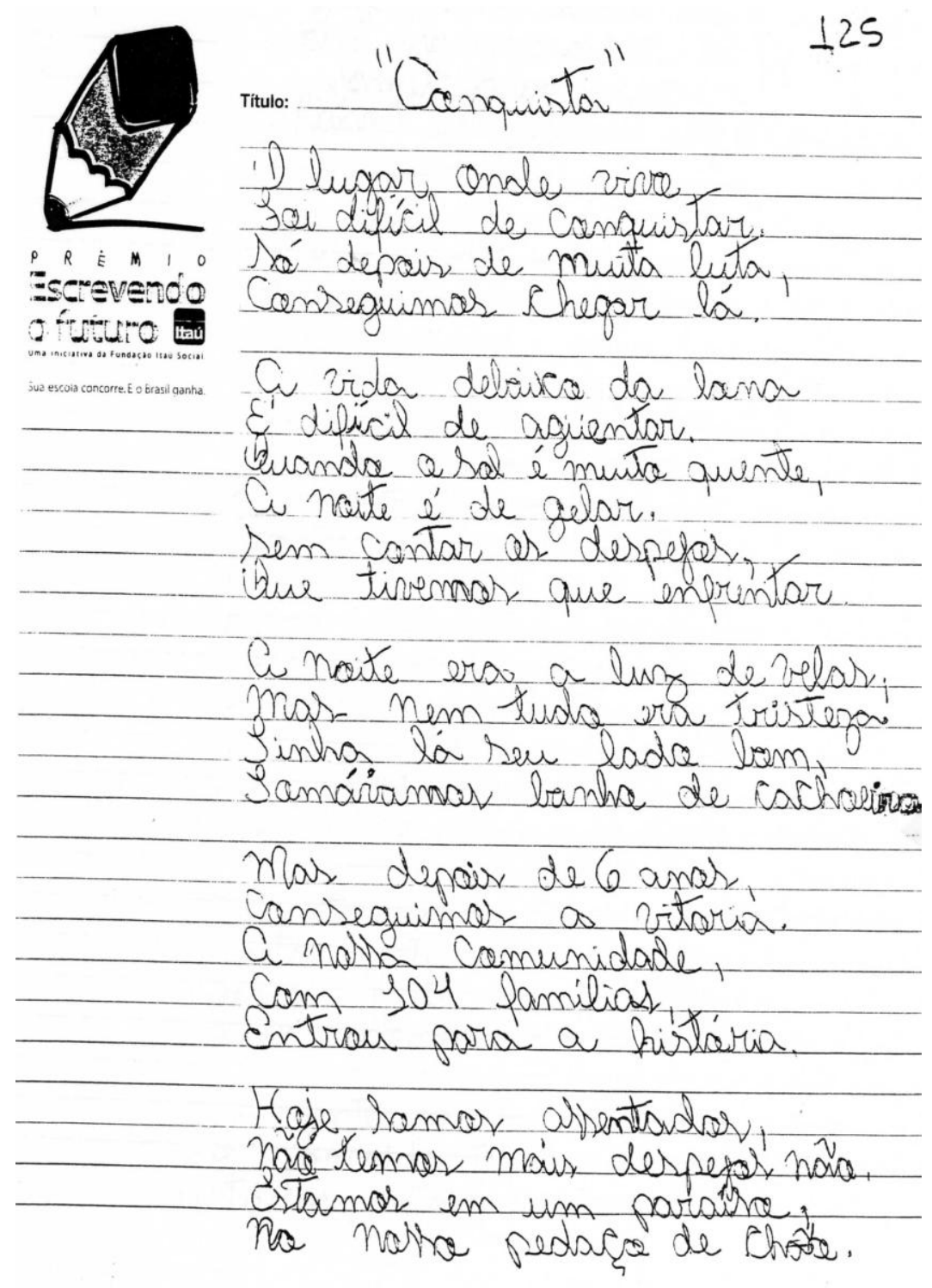

1) lugar, de que falsi

Ea ce lisenge nañ. Gue amoumar de carafáx.

Nas etses anas que hafrem now reclamamar nas

Tar-que agara temos

nolsa pedacso de chace! 


\begin{tabular}{|c|c|}
\hline Série & \\
\hline Feminino & \\
\hline $\begin{array}{l}\text { "Conquista" } \\
\text { O lugar onde vivo (6) } \\
\text { Foi difícil de conquistar (8) } \\
\text { Só depois de muita luta, (7) } \\
\text { Conseguimos chegar lá (7) } \\
\text { A vida debaixo da lona (8) } \\
\text { É difícil de aguentar (7) } \\
\text { Quando o sol é muito quente, (7) } \\
\text { A noite é de se gelar. (7) } \\
\text { Sem contar os despejos, (6) } \\
\text { Que tivemos que enfrentar. (7) } \\
\text { A noite era a luz de velas, (7) } \\
\text { Mas nem tudo era tristeza (7) } \\
\text { Tinha lá seu lado bom, (7) } \\
\text { Tomávamos banho de cachoeira. (10) }\end{array}$ & $\begin{array}{l}\text { Mas depois de } 6 \text { anos, (6) } \\
\text { Conseguimos a vitória. (7) } \\
\text { A nossa comunidade, (7) } \\
\text { Com } 104 \text { famílias, (7) } \\
\text { Entrou para a história. (7) } \\
\text { Hoje somos assentados, (7) } \\
\text { Não temos mais despejos não. (8) } \\
\text { Estamos em um paraíso, (7) } \\
\text { No nosso pedaço de chão. (8) } \\
\text { O lugar de que falo, (6) } \\
\text { Não é longe não. (5) } \\
\text { É o Assentamento nova conquista, (10) } \\
\text { Que amamos de coração. (8) } \\
\text { Mas esses anos que sofremos, (8) } \\
\text { Não reclamamos não. (6) } \\
\text { Porque agora temos (6) } \\
\text { Nosso pedaço de chão! (7) }\end{array}$ \\
\hline
\end{tabular}

Há no caso do poema "Conquista" um relatório feito pela professora que, além do caráter descritivo, sem traços avaliativos a respeito da qualidade das atividades, é bastante sucinto. Somente na oficina 3, percebe-se a dinâmica de sala de aula e a intervenção positiva da professora:

$\mathrm{Na} 3^{\mathrm{a}}$ oficina, "Produção individual", os alunos apresentaram dúvidas sobre o tema. Eles não conseguiram entender o que era para ser escrito, se era para falar sobre a casa, a rua, o bairro, a cidade.

Sugeri que pensassem em tudo aquilo que fazia parte do seu dia-a-dia, os lugares que frequentavam, o que faziam, como vivem.

Já na Oficina 7, há apenas a descrição de mais uma dificuldade, em tom de constatação: "Na $7^{\mathrm{a}}$ oficina, "Brincando um pouco mais com as palavras: rimas, repetições e aliterações", os alunos tiveram dificuldade para entender o que é aliteração." Como se observa, não existe a descrição de qual solução foi dada ou se os alunos permaneceram com essa dúvida.

Talvez a dúvida grupal sobre o trabalho sonoro pudesse esclarecer a oscilante presença do metro e das rimas não só neste poema como também em outros, em que isso evidencia um "estar em processo", uma das questões a serem resolvidas ainda pela proposta. Pelos resultados vistos até aqui, é possível conceber que da forma como está organizado, há 
um excesso de elementos sendo trabalhados com os alunos. Alguns grupos como Nova Conquista indicam essa oscilação

Há estrofes com rima toante ( $3^{\mathrm{a}}$ estrofe) e outras com consoante $\left(2^{\mathrm{a}}, 5^{\mathrm{a}}\right.$ e $6^{\mathrm{a}}$ estrofes). Essa alternância vincula esses trechos do poema a processos e textos de variadas épocas e de diversos efeitos. A rima toante na $3^{\text {a }}$ parece compor de forma mais coesa a estrofe, combinando o recurso sonoro a um ritmo discreto, de versos polimétricos, que adere a uma certa sisudez da descrição das condições de vida dos sem-terra. Quando a aluna-poetisa utiliza a rima consoante na $2^{\mathrm{a}}$ estrofe parece estar em busca da melhor forma de encadear $\mathrm{o}$

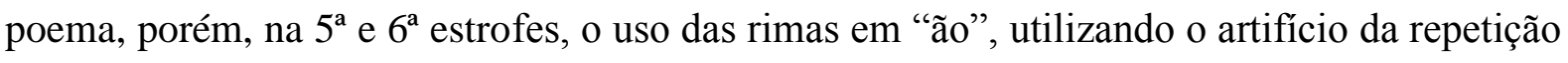
no fim do verso, parece apenas cumprir a exigência de se usar os elementos da poesia, pois a retirada de um ou outro termo que se repete não altera o verso. É o caso de "Hoje somos assentados / não temos mais despejos não / Estamos em um paraíso / Nosso pedaço de chão." A retirada do advérbio "não" do segundo verso dessa estrofe só altera a rima, pois o reforço introduzido por essa repetição marca um uso sem eco nos outros versos de uma prosódia diversa, acentuando uma fala emocional.

Ligado a essa mudança de ritmo está outro processo de natureza retórica (e coesiva), o da catáfora. A aluna-poetisa monta a história do lugar onde vive pela ação dos moradores que a constituíram. Isso abre espaço para a elaboração autoral possível: a valoração dos atores envolvidos e não, do lugar que recebe a história e nos faz parte dela, porque o assentamento só existe por essa ação. A proximidade da história do lugar e da vida desses alunos faz com que a apropriação seja feita com os traços utópicos e ufanistas relativos a momentos fundadores. Mimetizando o percurso da luta pelo lugar à narrativa dos versos, a aluna parece preparar o leitor, nas cinco primeiras estrofes, acompanhá-lo para, então, apresentar o nome do lugar (assentamento Nova Conquista) como construção da história vivida por esse grupo identificado na primeira pessoa do plural. A aluna pode ter vivido esse momento ou não, e qualquer que seja a resposta na realidade, resta o poema, no qual ela recriou essa experiência marcando de forma diversa a sua voz. Não se trata da voz individual ainda, no entanto, um deslocamento se deu: o lugar passou a ser um objeto do desejo e a memória, uma forma de prolongar o prazer de possui-lo. A posse, porém, não é feita pelo sujeito. Toda a comunidade está presente nessa "conquista". Assim, nas estrofes, a voz do enunciador aparece na $1^{\text {a }}$ pessoa do singular (duas ocorrências marcadas em laranja) e do plural (11 ocorrências verbais e uma duas pronominais marcadas em verde) com predomínio dessa segunda forma: 


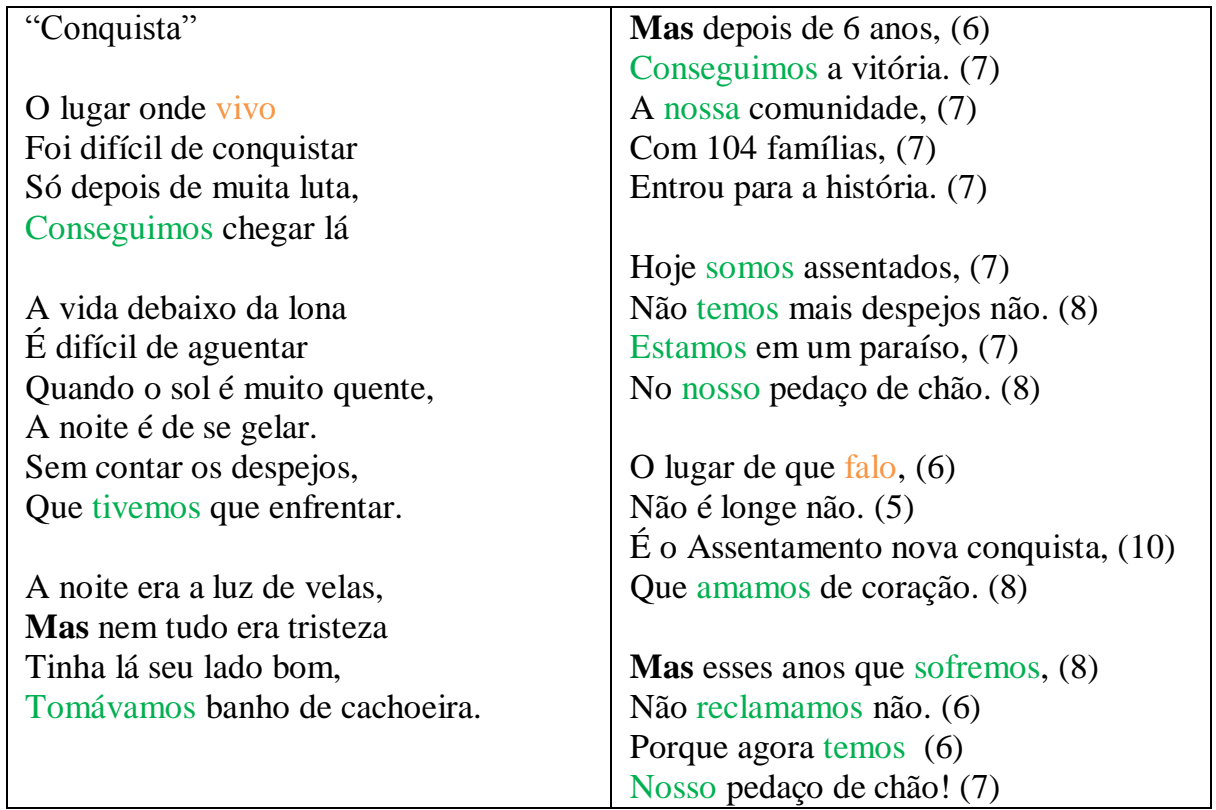

Aliando-se a um grupo, o enunciador diminui a possibilidade de o leitor se identificar com essa comunidade pela palavra. A identificação, quando ocorrer, será por empatia, pela narrativa, uma vez que o "nós" do poema é exclusivo, reforçando o traço etnocêntrico que cada comunidade apresenta para criar sua identidade.

Porém, como nos poemas analisados anteriormente, encontram-se brechas para que se distinga, mesmo que precariamente, o timbre da voz da aluna-poetisa no coro, trata-se do espaço num quase sussurro entre o "nós" de caráter absoluto (e, por que não dizer, majestático) e o ritmo hesitante do poema. Parece ser a resistência possível, diante de um discurso que valoriza a conquista do local pelos sem-terra, no reavivamento da memória sobre o processo de ocupação e posse definitiva. Um discurso de conquista efetuada por esse "nós", construído no imaginário da aluna-poetisa. Talvez, por essa razão, avesso a falas individuais. No espaço do poema, encontram-se os embates da reforma agrária e a da justificação das ações desses grupos que necessitam da terra: o assentamento. Esses embates são indiciados pelo uso da conjunção "mas", como a impedir o esquecimento de um passado de lutas, a fim de compreender o presente de construção e conquista, em uma chave de resistência:

Mas esses anos que sofremos,

Não reclamamos não.

Porque agora temos

Nosso pedaço de chão! 
Por fim, a antonomásia construída ad hoc para o lugar onde a aluna vive, "nosso pedaço de chão", indica também a flutuação que existe na construção de sentidos que oscilam entre o concreto (pedaço de chão, literalmente) ao abstrato (a idéia de casa, de lar a partir desse concreto). No caso deste poema, esse confronto entre a construção de sentidos, ao trazer a dicção do épico para a dimensão do "nós", dá a impressão de aprisionar a voz do sujeito. Estaria esse enunciador refém desses ideais, a ponto de não poder questionar a situação, como ocorreu em quase todos os poemas? Nesse caso, as possibilidades de dizer o lugar são marcadas por uma luta que funda a identidade do grupo e furta ao sujeito uma identidade própria. Dizer o lugar é "dizermos".

Em "Conquista", o gênero poético não parece ser suficiente para romper com esse isolamento, mas, pela presença da estrutura em rede em que os vários elementos compõem a unidade temática, abre-se espaço para a ação do sujeito, pois os níveis podem se relacionar em tensão ou conjunção. No poema, a hesitação do ritmo e das rimas indicia uma adesão parcial e não total ao tratamento dado ao tema. A voz da aluna-poetisa não se opõe ao coro principal, mas canta da forma que sabe ou quer. 


\subsection{Minha pátria, minha língua: sonho possível?}

Após a análise dos poemas, observa-se que a representação do lugar pelo olhar dos alunos tornou-se uma das questões principais, permeada pela especificidade do poema e não, o contrário. Em outras palavras, hierarquicamente, o tema sobrepõe-se ao gênero selecionado. Em conformidade com essa questão, Maria da Glória Bordini (1991, p.30) afirma: "a condensação dos sentidos operada pela palavra poética não procede, porém, apenas da imagética ou da melopéia. Para poder entender por que o poema significa mais do que o conjunto de seus signos, é preciso ir além do nível verbal, entrando no campo das representações. Todo discurso evoca não as coisas, mas os seus conceitos." Evoca, como afirma a autora, de dentro, por meio da formulação dessa linguagem que reconstrói o objeto não ficando a serviço dele. No processo de elaboração e seleção dos poemas para o Prêmio, os critérios para avaliação, embora necessários para assegurar uma unidade de trabalho, se tornaram grades de verificação para o professor que orientou o aluno a compor o poema de forma a responder a eles. É o caso do critério "busca de informação sobre o tema" em que o uso das informações sobre o local serve, na maioria dos poemas, para a criação de um panorama histórico que pouco resgata ou colabora para o estabelecimento das identidades do aluno e do local no momento da enunciação.

Isso ocorre pelo fato de o aluno-poeta estar envolvido em representações sobre o lugar e também sobre os gêneros poéticos (analisadas com mais vagar no capítulo 3). As representações, em geral, são prescritivas, "isto é, elas se impõem sobre nós como uma força irresistível. Essa força é uma combinação de uma estrutura que está presente antes mesmo que nós comecemos a pensar e de uma tradição que decreta $o$ que deve ser pensado." (MOSCOVICI, 2007, p. 36) Assim, os alunos são "atingidos" por essas forças que se materializam em discursos utópicos e de redenção sobre o local em que vivem. As marcas desse diálogo tenso em que o aluno mostra pouco quem é se configuraram nos poemas em um ethos cidadão, preocupado com o futuro, e um pouco envelhecido. As preocupações que surgem nos textos parecem solicitar a adesão do leitor pelo reconhecimento especular. Muitos versos soam como convites para que o leitor adulto perceba que os alunos-poetas são confiáveis e atentos ao entorno como todo cidadão deve ser.

Embora as relações afetivas estejam presentes nos poemas, tal como se preconizou na oficina 11, "Reconhecendo emoções e sentimentos, tornando-se poeta": alguns alunos-poetas 
amam sua cidade ("Conquista"); outros se preocupam com seu futuro ("Desabafo"); têm orgulho das realizações alcançadas lá ("Vivendo entre Araçás, bois e progresso"), as coerções das vozes institucionais circunscrevem lugares específicos para o enunciador. Com exceção de "Diversão e poeira", os enunciadores parecem estar com "roupa de festa", ou seja, envoltos em uma aura heteroglóssica que abafa suas vozes.

Dessa forma, pode ser traçado um paralelo com a situação descrita por Bazerman (2005, p. 69), ao tratar de formulários de imposto de renda. Ele afirma que nesse gênero há um intenso diálogo com os "elaboradores" de formulário, "que identificam as principais categorias e os termos de auto-representação" além dos leitores com poder de sancionar positivamente a declaração ou não. Os elaboradores ainda estão na perspectiva do enunciador. O mesmo ocorre com os "elaboradores" do fascículo (e dos critérios de avaliação), os alunos-poetas tentam entender quais são suas expectativas e acabam por formulá-las como parte da representação da res publica. Não é difícil entender como isso ocorre porque, como formula Bazerman

\begin{abstract}
na medida em que a política é reduzida a questões de economia e de mercado, e na medida em que os mais importantes atores do palco político coincidem com aqueles que detêm o poder econômico, os valores que não são do mercado terão dificuldade em ter voz na discussão política, porque situam-se em gêneros nada afeitos à expressão de valores e interesses não-econômicos. (2005, p. 127)
\end{abstract}

Como se observou nos poemas, falar da cidade é também mostrar as vantagens econômicas que ela oferece (ou não), identificando a vida como algo que se faz quando se está na esfera do mercado. Vários poemas indicam que, na cidade, se pode comprar, vender, ganhar dinheiro (ou não). Tem-se a impressão que o gênero poético ao tratar desse tema foi sequestrado pela esfera do financeiro. Nessa nova ordem, a posição autoral também é sequestrada pela dificuldade do aluno-poeta de tornar o econômico, político.

Assumir uma posição autoral, segundo Bakhtin (FARACO, 2005), envolveria o distanciamento axiológico que o aluno toma emprestado de outrem: a voz institucional na posição do professor; a voz institucionalizada pelo grupo na narrativa fundadora deste mesmo grupo; a voz do marketing presentes nos clichês. Essas vozes, porém, parecem carregar a autoridade para caracterizar o lugar com um dizer instituído e legitimado para aquele indivíduo. As cenas transcritas na produção do aluno são conhecidas e tentam a adesão, pela familiaridade, de outros leitores como ele. 
A busca pelo leitor (além daquele pressuposto pelas orientações do fascículo, que existe em função do próprio prêmio, pelo fato de haver comissões avaliadoras) se instaura como elemento importante para compreender como os alunos formularam as representações do lugar no poema. Esse dado, muitas vezes, promoveu um certo estreitamento das possibilidades e a apropriação do espaço pela palavra se esvaziou. Em outros casos, ainda que permanecendo a questão da captação do outro, conseguiu-se a adesão do leitor, sem nomeá-lo explicitamente. A poesia, como afirma Silviano Santiago (1989) sobre a obra de Ana Cristina César, pede leitores, ou um leitor que é, ao mesmo tempo, singular e anônimo e, nessa relação com ele, o texto poético se estabelece como gênero discursivo para além de características formais únicas que não possibilitam nos dias de hoje uma taxonomia exata.

Assim os elementos presentes nos poemas apontam para outras representações metaenunciativas, aquelas que se referem aos gêneros poéticos e que permitem delinear estratégias para a elaboração do poema no espaço escolar. Essas convergem para a questão da autoria como Fiad apresenta em seu texto "ensino e autoria" ao retomar as ideias de Possenti:

\footnotetext{
- a noção de autoria deve ser pensada junto às noções de singularidade e estilo;

- a autoria é detectável através de indícios e aqui deve remeter-se às considerações de Ginzburg (1986) sobre o paradigma indiciário;

- para se dizer que um texto tem autoria, não é suficiente que ele seja um texto correto gramaticalmente, nem que seja textualmente satisfatório. Isso significa que, na sua visão, as marcas de autoria são da ordem do discurso e não da gramática ou do texto;

- duas atitudes de um autor seriam "dar voz aos outros" e "manter distância" em relação ao que dizem e em relação a seus interlocutores;

- a autoria é encontrada no "como" e não no "o quê" é expresso. (FIAD, 2008, p. 218)
}

Dos poemas analisados, o que aparece nos textos quanto à autoria é um ethos que cede espaço para outros discursos, relacionados aos gêneros históricos - em sua maioria, à história local. Esse ethos se mostra fiador do discurso do poeta como afirma Maingueneau (2006, p.70): “A especificidade de um ethos remete, de fato, à figura de um "fiador" que, por meio de sua fala, se dá uma identidade que está de acordo com o mundo que ele supostamente faz surgir." Essa questão se volta para a constituição do poético, ainda na discussão empreendida por Maingueneau (2006, p.70) quanto ao poder de persuasão do ethos, “as 'idéias' suscitam a adesão do leitor por meio de uma maneira de dizer que é também uma maneira de ser. Tomado pela leitura em um ethos envolvente e invisível, participa-se do mundo configurado pela enunciação, acede-se a uma identidade de certa forma encarnada." No caso dos poemas, o ethos apresentado deriva de outro que estabelece 
limites e formas de atuação pelos discursos, e é assim um ethos de segunda mão, o leitor reage à sombra de outrem na voz do aluno-poeta.

Mesmo se tratando de apenas um texto de cada aluno, o ethos tem o reforço da letra dos alunos-poetas (todos manuscritos) que corporificam ao lado de suas palavras, um tom. A grafia, como a voz faz, projeta uma impressão no leitor e confesso que, ao lê-los, essas imagens gráficas "soaram" ao lado das palavras, uma vez que "o ethos não age no primeiro plano, mas de forma lateral. Ele implica uma experiência sensível do discurso, ele mobiliza a afetividade do destinatário." (MAINGUENEAU, 2006, p. 53) Muitas vezes, essa corporificação contradiz o texto poético, isto é, discurso de adulto em letra de criança.

A figura de um "fiador" remeteria também ao que Tezza (2006) afirma ser a autoridade ética da poesia. Uma linguagem que se vale de recursos como a rima, os efeitos sonoros, a estrutura em versos e a criação de uma linguagem afastada do uso regular que remete a cada instante a outros discursos e vozes. Assim, a hesitação dos alunos-poetas aqui representados pode ser o espaço para questionarem a própria legitimidade da autoridade. A representação de poesia, à qual foram expostos, parece, em alguns momentos, espaço do outro. Nesse lócus, instituído nos poemas por forças externas, a resistência do aluno se instaura no ritmo dos versos. A oscilação do metro, a ausência de um ritmo único é a resposta do aluno. Na hesitação, fundam-se os traços autorais que indicam o trabalho de compreensão do lugar onde se vive e sua tentativa de apreensão desse lugar pela desordem na busca talvez de uma "nova ordem".

Sobre essa questão, Tezza (2006) analisa como a autoridade da voz do poeta encontrase em crise nos tempos atuais:

Num mundo fragmentário e prosaico como o nosso, não é tarefa fácil sustentar o poder dessa linguagem sem se entregar aos lugares comuns da cultura da massa ou aos universais poético-religiosos, que, parece, são a hegemonia que nos restou. Não é fácil, mas é possível. (...) (p. 215)

Não é fácil para o poeta, não é fácil para o aluno-poeta. Nesse percurso de incertezas para o poético, surge a questão da representação do gênero. Os alunos-poetas indicaram que o poema era espaço de "coisas sérias", retomando representações mais tradicionais. Na contracorrente, dos diários, dos blogs e afins, esses alunos mostraram que a retórica exigida para o tema levava-os para longe de um egocentrismo atribuído aos adolescentes ou préadolescentes, pouco do lirismo permaneceu. 
O que se observa nos poemas é a postura comprometida dos alunos como porta-voz de uma instituição ou da administração pública, que encontra em outras retóricas (do texto publicitário e até do político ${ }^{52}$ ) seu espaço de autoria.

De onde vem essa nova autoridade? Quais representações responderiam a essa questão? O tema definiria caminhos e escolhas de formas para os gêneros poéticos? Afinal como são os gêneros poéticos?

${ }^{52}$ Cf. Poema "Conquista", p. 111-115. 


\section{Capítulo 3}

\section{Reflexões e Propostas}

Neste capítulo, a reflexão sobre o ensino de poemas está entrelaçada a propostas com o intuito de apontar percursos possíveis para o trabalho plural com os gêneros poéticos em sala de aula. 
um bom poema

leva anos

cinco anos jogando bola, mais cinco estudando sânscrito, seis carregando pedra, nove namorando a vizinha, sete levando porrada, quatro andando sozinho três mudando de cidade dez trocando de assunto, uma eternidade, eu e você, caminhando junto 
As considerações que se seguem, na maioria das teses, costumam ser apresentadas logo no início. Nesse caso, porém, como foi explicado à página 19, a inversão decorre do percurso desenvolvido nesse trabalho uma vez que a reflexão teórica que sustenta a proposta de encaminhamentos (e parte da análise dos poemas) para o ensino dos gêneros poéticos ficaria menos clara, caso fosse definida antes de serem mostrados esses caminhos. Essa reflexão resulta do diálogo entre os suportes teóricos voltados ao estudo do poema e as teorias sobre os gêneros discursivos.

Assim seria possível afirmar que este capítulo se pauta pela busca de respostas aos questionamentos de Tezza sobre a poesia nos dias de hoje, tão marcados pelo predomínio da prosa:

\begin{abstract}
Como sustentar, nos dias de hoje, uma linguagem poética pura? Que pressupostos sociais são necessários para uma voz "indiscutível" se fazer ouvir e ser respeitada? Em que medida - com o Estado e a Igreja separados, com a laicização completa da vida política dos grandes centros do Ocidente, com a decadência dos grandes sistemas interpretativos do mundo, com a idéia do indivíduo como valor supremo, com o império do universal da prosa (no sentido comum e no sentido bakhtiniano da palavra) -, em que medida a poesia sobrevive como gênero? (TEZZA, 2003, p.268)
\end{abstract}

A impressão que se tem é que a poesia se configura como tal desde os primórdios da humanidade. Já afirmava Octavio Paz, em Signos em Rotação (1996, p. 12): "não há povos sem poesia, mas existem os que não têm prosa". Naquele momento, a poesia estaria ligada a outras manifestações como a dança e a música em total simbiose, sem que se pudesse falar nas conhecidas e, muitas vezes necessárias, divisões didáticas para estudo. Assim, ela surge como uma intersecção de gêneros e vai alcançando, à medida que os grupos sociais avançam, cronológica e estruturalmente, configurações e usos sociais diversos, chegando a se deslocar desse imbricamento para ganhar autonomia e se tornar um gênero secundário, segundo Bakhtin (2003), no universo da escrita. Ou pelo menos assim compreende-se a mudança a partir do que sobreviveu em pergaminhos e monumentos (PAZ, 1996).

Desse primeiro apagamento da multiplicidade da poesia, por causa de suas mudanças temporais, das formas ritualizadas às formas fixadas estruturalmente pelo uso, surge um problema para o século XX e XXI: compreender o poema, hoje, é investigar um enunciado 
que exila essas antigas formas composicionais e traz uma desordem, reflexo das novas condições do contemporâneo.

A poesia já possuiu uma importância tal na sociedade, a ponto de se qualificarem os poetas como vozes privilegiadas e, mesmo nos momentos mais recentes dessa jornada, de se utilizar a expressão "poeta marginal" indicando que essa posição fora do grupo também seria privilegiada, dada a necessidade de nomeação. Essas denominações demonstrariam a relevância desse autor para o grupo social, apontando hoje uma crise. Talvez ideológica. Talvez, como afirma Cristóvão Tezza, em Entre a prosa e a poesia, Bakhtin e o formalismo russo, (2003, p.288), axiológica, ou seja, "uma desesperada falta de mitos a quem cantar, convincentemente, a nossa poesia: é a autoridade poética que está em crise.”

Para situar a crise por que passa a poesia, o autor indica a concepção de Bakhtin (TEZZA, 2006) da poesia em oposição à prosa, como um gênero monológico. Apesar disso, não se está anunciando o fim da poesia em tempos de diversidade e respeito à alteridade, basta lembrar um dos títulos de livro de José Paulo Paes, A poesia está morta, mas juro que não fui eu (1988), em que a sensibilidade do poeta poderia indiciar essa questão, mas contrariamente revitaliza formas e usos para o poema, como outros poetas contemporâneos.

Como é possível compreender a questão do caráter monológico do poético? Tezza (2003) apresenta as condições para a compreensão do conceito bakhtiniano:

\footnotetext{
Por ora, observemos o seu ponto de partida - isto é, onde Bakhtin coloca a questão e de que modo ela deve ser compreendida, não em termos simplificados de contraste entre "dialógico" e "monológico", decorrente de uma confusão de conceitos entre o plano da linguagem e o plano da literatura. Outra questão importante é perceber que, para Bakhtin, a poesia também é uma manifestação da linguagem concreta, do momento verbal, não do seu esqueleto reiterável; é nele, no momento verbal, que ela se realiza, nele que ela se especifica e nele que deve ser compreendida. (2003, p.240-241)
}

\subsection{Poema: gênero discursivo}

Para reposicionar o poema como gênero, é necessária a análise do contexto que condiciona o momento verbal, distinção que Fiorin (2006) apresenta, afastando os valores ideológicos que poderiam criar obstáculos para essa reflexão: 
(....) é necessário distinguir dois planos teóricos em que Bakhtin trabalha o conceito de dialogismo: o da natureza da linguagem e de sua manifestação na composição do discurso. Como a linguagem é constitutivamente dialógica (o que denominamos "primeiro conceito de dialogismo"), tanto a prosa quanto a poesia são dialógicas. Ambas se constituem em oposição a um outro discurso. Por isso, do ponto de vista bakhtiniano acerca do funcionamento real da linguagem, é um erro dizer que a poesia seja monológica. Já do ponto de vista da manifestação composicional do dialogismo (segundo conceito de dialogismo), Bakhtin mostra que a poesia não trabalha, em sua composição, com o plurilinguismo, como faz o romance. (2006, p.78-79)

A manifestação composicional da poesia excluiria o plurilinguismo ao centralizar toda a autoridade na voz do enunciador. Em termos composicionais, essa centralização se encontra principalmente no "verso" que mantém esse isolamento concentrando em si outros elementos numa rede de recíprocas dependências. Trata-se de figuras de som como aliterações, assonâncias; paralelismos sintáticos; criações lexicais ou deslocamentos semânticos, em processo neológico; figuras de linguagem e pensamento, em topoi já consagrados ou outros discursivamente instaurados pelo poema entre os limites dos versos, criando entre essas linhas processos próprios de construção de sentidos.

No momento em que o poeta elabora seu texto, o outro (aquele que pode se colocar na posição de leitor) está isolado por essa barreira física e discursiva em que qualquer elemento pode adquirir novos significados e valores, alheios a convenções imediatas da comunicação. Os versos seriam esses espaços de implicaturas conversacionais, tal como as concebe Grice ${ }^{53}$. Quebras das máximas associadas ao princípio que rege a conversação, as implicaturas não dependem "da significação usual, sendo determinadas por certos princípios básicos do ato comunicativo" (COSTA, 2009, p. 13). O poeta não buscaria a comunicação imediata e convencional; seu texto estabeleceria não somente o tema, mas a situação enunciativa em que cada elemento adquiriria novos significados num processo de emulação de uma realidade desejada.

Mesmo o código linguístico que apresenta certa estabilidade estrutural é atingido por essa forma de composição particular, específica dos gêneros poéticos, em decorrência de uma das características centrais da poesia: o uso particular de um código linguístico, como formula Levin (1975, p. 66-7):

\footnotetext{
${ }^{53}$ Para os conceitos centrais de Grice: princípio da cooperação; máximas conversacionais e implicaturas, cf. COSTA, 2009. Quanto aos deslocamentos promovidos nos contratos estabelecidos na leitura do texto literário cf. MAINGUENEAU, 2002.
} 
(....) podemos ver que num poema é usada uma espécie particularmente restrita do código. Como resultado desse fato, ao ler um poema, verificamos que os sintagmas geram paradigmas específicos, e que estes paradigmas, por sua vez, geram os sintagmas, levando-os assim de volta ao poema. Dito de outra maneira, o poema gera seu próprio código, do qual é a única mensagem. (grifo meu)

No entanto, a leitura do poema é possível, porque essa distância do real é calculada de modo que o leitor consiga re-elaborar todo o texto em uma nova rede interpretativa, recriando as condições que geraram não somente o código particular àquele poema, mas também as condições que conferem a ele sentido, como também indica Levin (1975, p. 103):

\begin{abstract}
Um poema (....) que é apresentado a um indivíduo como uma mensagem, traz embutidos em si equivalências (acoplamentos) tais que assistem o indivíduo a reproduzi-lo de maneira única; incita, em consequência de sua pressão sistemática, às mesmas seleções do código lingüístico. Desta maneira, a mensagem real, isto é, o próprio poema - torna-se permanente.
\end{abstract}

Muitas vezes, porém, retomar essas condições implicadas na forma como o poeta selecionou o código (ou o deslocou) pode levar a um afastamento do leitor, envolvido por outras formas de compreender a organização dos gêneros. Esse distanciamento que o poeta impõe a si em seu texto poderia mesmo ser tomado como anacrônico em nossos dias, não fosse pela tendência que se observa na poesia contemporânea (também na brasileira), de forte prosaísmo, uma resposta para o período de crise da autoridade da poesia.

Com essas novas condições, não teríamos a morte, mas uma mudança do poético. A prosificação do poético garantiria a presença de múltiplas vozes, sustentadas pelo poeta ou por ele amparadas. Basta trazer à lembrança alguns poemas que já apontam para essa corrente em configuração intergenérica, tais como, "Maturidade", de Oswald de Andrade, e "Poema tirado de uma notícia de jornal", de Manuel Bandeira, que serão comentados a seguir a partir desses traços intergenéricos e prosaicos.
MATURIDADE 54
O Sr.e $\mathrm{Sr}^{\mathrm{a}}$ Amadeu
Participam a V. Ex
O feliz nascimento
De sua filha
Gilberta

Em "Maturidade", o espaço do poema, cujos versos cedem lugar para os dizeres do gênero cartão de participação, serve para anunciar o nascimento da filha do Sr. e Sra.

\footnotetext{
${ }^{54}$ Um dos poemas de "As quatro gares" do Primeiro caderno do alumno de poesia. In ANDRADE, Oswald de. Obras completas e Poesias reunidas. $5^{\text {a }}$ ed. Rio de janeiro: Civilização Brasileira, 1978, p. 161.
} 
Amadeu. Indício de outros tempos, esse tipo de cartão tinha a função social de indicar que havia um novo membro na família, com o intuito de reposicionar os envolvidos ao divulgar esse fato da esfera privada para a pública. Por essa função, abrem-se, no poema, dois momentos enunciativos: o dos versos, com a informação do nascimento, em primeiro plano; e o da leitura da participação do nascimento feita pelo enunciador do poema e indicada no título.

Embora aparentemente o que domine, pelo volume visual, seja a informação veiculada pelo gênero prosaico (cartão) ainda que quebrada em versos (enjambement), a avaliação do enunciador marcada no título guia a nossa leitura num terceiro momento enunciativo, quando se apresenta uma tarefa aos leitores: concordar com o enunciador ou indicar outros fatores que levariam à maturidade, além do nascimento, por vezes acidental, de um filho. Essa discussão entre leitor e enunciador é também a discussão do papel da poesia diante desses fatos. $\mathrm{Na}$ incorporação das vozes daquela família, o enunciador do poema propõe uma nova via para o poético. Não se trata de exaltar a beleza do recém-nascido, mas indicar as consequências da presença da filha: o compromisso na ordem social. Trata-se de abrir espaços para a discussão da vida como ela se manifesta e dos valores que são impostos a nós. Trata-se de maturidade que chega a nós pelos olhos dos outros.

A relação intergenérica também surge no poema de Bandeira:

\section{POEMA TIRADO DE UMA NOTÍCIA DE JORNAL ${ }^{55}$}

João Gostoso era carregador de feira-livre e morava no morro da Babilônia num

Uma noite ele chegou no bar Vinte de Novembro barracão sem número

Bebeu

Cantou

Dançou

Depois se atirou na Lagoa Rodrigo de Freitas e morreu afogado.

Movimento contrário ao do poema de Oswald ocorre no poema de Bandeira, pois, se em "Maturidade", o espaço do poema estava tomado por outro gênero, em "Poema tirado de uma notícia de jornal”, o outro gênero (notícia) está pressuposto. Por causa dessa presença no título, estão também pressupostos o tema, a estrutura composicional e o estilo da notícia, que instauram no leitor a expectativa de deslocamento que efetivamente ocorre.

\footnotetext{
55 Do livro Libertinagem, In BANDEIRA, Manuel. Estrela da Vida Inteira. 19 a ed. Rio de Janeiro: Jose
} Olympio, 1991, p. 107. 
No poema, o enunciador em terceira pessoa, como na notícia, apresenta os fatos sem adjetivação, caracterizando-os com elementos concretos (carregador de feira-livre; morador do Morro da Babilônia) e verbos de ação. Há os elementos que fazem parte da estrutura composicional da notícia: o quê (uma morte), quem (o carregador de feira-livre), quando (uma noite), onde (na lagoa Rodrigo de Freitas), como (afogado) e por quê (inconclusivo). Porém, as semelhanças com a notícia que levariam a um rompimento do gênero poético, cessam nesse ponto. $\mathrm{O}$ fato noticiado parece ir perdendo terreno para uma leitura particular do enunciador também leitor. Assim nossa leitura filtrada por essa percepção alheia aponta para questões ainda não respondidas pelo jornal como o por quê, insinuando uma certa gratuidade de alguns atos que não podem ser revertidos.

O gênero notícia é abafado pelo uso de certas figuras de linguagem como as sonoras (o homeoteleuto em "bebeu /cantou/ dançou/ e depois se atirou na lagoa Rodrigo de Freitas e morreu afogado") e pela ausência de nexos coesivos, que indicariam as relações precisas entre as ações verbais (exceção feita ao uso da conjunção coordenativa aditiva "e" que acaba por exercer função semelhante à da posição dos versos, ou seja, justapor). A objetividade requerida no gênero notícia perde espaço para a perplexidade do sujeito que lê a notícia e reconstrói a narrativa de forma bastante frouxa por não saber a razão do ocorrido. O que surge é uma visão descolada do fato em que cabem várias versões, todas possíveis, todas insuficientes.

O peso da notícia, porém, permanece e o poema referencia um gênero importante para a formação da consciência crítica, colocando-o como fonte também do poético. No entanto, devido a essa importância, ao desconstruir a notícia paulatinamente, o texto poético aponta para as contradições de se ter uma só visão do fato. Seria o modo objetivo de ver a realidade suficiente? O poema sinaliza que nós não estamos satisfeitos. Cada leitura que fazemos evidencia essa insatisfação que mais uma vez reforça o papel do poético nos nossos dias, como poder paralelo ao da prosa.

Absorver outros gêneros, característica do romance, segundo Bakhtin, no século XX acaba por se tornar também a característica da poesia, como se observou nos poemas "Maturidade" e "Poema tirado de uma notícia de jornal". Isso ocorre por serem estas "épocas em que abundam as paródias, as estilizações e outras formas de bivocalidade.”, afirma Fiorin (2006, p. 88). Esses alinhamentos poderiam ser considerados negativamente se considerarmos as estruturas que envolvem os gêneros, mas, segundo Bakhtin (2009, p. 194), 
as tarefas históricas em tais épocas (como a nossa) seriam "demover o desajuste da prosa e da poesia, destruir a distância extremamente acentuada entre elas (sem anular suas peculiaridades)." ${ }^{, 56}$. Assim, mesmo com a prosificação, o discurso poético se sustenta. Quais os elementos que o fariam poético? Tezza apresenta um traço central, que esteve no horizonte das análises dos poemas, no capítulo 2, na abordagem das vozes e do ethos presente nos poemas dos alunos. Trata-se da visão de mundo hegemônica, "nem sempre com correspondência concreta de alguma hegemonia na vida social (embora em muitos momentos da história essa hegemonia tenha sido um pressuposto fundamental do estilo poético, como no épico), mas construída pela própria exigência do centro de valor poético.” (TEZZA, 2003, p. 269)

O apoio para essa visão não estaria, a princípio, num conjunto de marcas formais em oposição às do discurso prosaico, uma vez que a sustentação da posição do poeta está "num tipo de relação que se estabelece entre autor-criador ('a unidade das intenções semânticas e expressivas do autor') e seu objeto.” (TEZZA, 2003, p. 270) No entanto, o poeta a estabelece no "estilo poético; estilo concebido para se adequar a uma única linguagem e a uma única consciência linguística" (BAKHTIN apud TEZZA, 2003), na manipulação da linguagem que isola as outras vozes, centralizando a voz do poeta. Trata-se de

\begin{abstract}
um processo que começa desde a disposição gráfica poética (que não se confunde com a disposição "comum", por si só portadora de uma axiologia prosaica, e daí advém a importância fundamental do aspecto gráfico como o primeiro divisor de águas) até a reiteração rítmica, sintática, semântica ou sonora (sob qualquer forma histórica) também de modo a potencializar o isolamento; o pano de fala do poeta é o silêncio; quando o poeta fala, só o poeta fala. (TEZZA, 2003, 270)
\end{abstract}

\title{
3.2 Então poemas são textos em versos?
}

Assim, mesmo na concepção discursiva, os versos poderiam ser o primeiro indício de que se está diante de um texto pertencente aos gêneros poéticos e, dessa forma o leitor poderia tomá-lo como parte da representação que faz desses enunciados. Se ele ignorasse os usos históricos dessa configuração gráfica, poderia até estendê-la a enunciados de outros gêneros. Embora essa constatação tenha em si uma certa obviedade (pois quando questionados muitos leitores reduzem o poema a texto em versos), o responsável por essa

\footnotetext{
${ }^{56}$ Grifos meus.
} 
naturalização das formas composicionais como suficientes - ou a tradição - parece instaurar um questionamento: por que aceitamos esse fato? Trata-se de um comportamento compartilhado socialmente? Teria a tradição força suficiente para indicar os percursos de isolamento do poeta e de sua voz no texto poético?

Muitos gêneros são identificados por suas formas composicionais. Cartas, petições, boletins de ocorrência, certidões de nascimento, como os enunciados poéticos, mudaram ao longo do tempo, mantendo alguns traços que marcam uma primeira aproximação do leitor (e garantem instrumental para o autor também). Essa característica acaba por nos conduzir a um traço da macroconcepção de gênero: o fato de vivermos pelos gêneros de tal maneira, que não se podem apagar certas características, tanto quanto não se podem apagar certas formações discursivas que se deslocam, sem, no entanto, desaparecerem ou mudarem em seus enunciados.

Se forem aceitas algumas formas composicionais como suficientes, quais seriam os critérios para caracterizar os gêneros poéticos de modo a permitir o seu reconhecimento e subsequente elaboração em um projeto para o ensino?

A resposta é plural como os gêneros em questão e remete a diversas concepções que não se anulam, mas nem sempre coincidem para permitir uma única forma de operacionalização, ou seja, o aproveitamento de múltiplos conceitos para abordagens a serem aplicadas em sala de aula.

Se considerarmos as concepções de Schneuwly e Dolz (2004), com os quais nos alinhamos nas abordagens de transposição didática, como a sequência didática ${ }^{57}$, verificamos que os gêneros poéticos não seriam colocados no quadro provisório de agrupamentos, pois os critérios, nesse caso, são determinados por domínios sociais de comunicação - narrar (cultura literária ficcional); relatar (documentação e memorização das ações humanas); argumentar (discussão de problemas sociais controversos); expor (transmissão e construção de saberes); e descrever ações (instruções e prescrições). Ao colocarmos lado a lado, a multiplicidade de gêneros poéticos e os aspectos tipológicos desses domínios, não é possível sustentar que haja apenas uma predominância, dadas as possibilidades encontradas. Um deles, porém, se aproxima do poético: o caráter ficcional, ou seja, fundar seu referente como interno - critério a ser retomado mais adiante.

${ }^{57}$ Cf. p. 28. 
Marcuschi, por sua vez, ao tratar da linha sociorretórica de Bazerman e outros, apresenta na intersecção dos conceitos de gênero, tipo e domínios discursivos, outras possibilidades de se estabelecer os critérios e abranger um número maior de gêneros para classificação. São aspectos relativos a funções, propósitos, ações e conteúdos. (2008, p. 159). Seriam suficientes? O autor continua sua reflexão:

Como é que se chega à denominação dos gêneros? Com certeza, as designações que usamos para os gêneros não são uma invenção pessoal, mas uma denominação histórica e socialmente constituída. E cada um de nós já deve ter notado como costumamos com alta frequência designar o gênero que produzimos. Possuímos, para tanto, uma metalinguagem riquíssima, intuitivamente utilizada e, no geral, confiável. (MARCUSCHI, 2008, p. 163)

Seria possível aceitar essa relação com os gêneros? Ela seria suficiente? Marcuschi, nesse ponto, indica a dificuldade que existe nas tentativas de se determinar o nome de cada gênero:

Como já notaram muitos autores, em especial Bakhtin (1979), os gêneros se imbricam, e interpenetram para constituírem novos gêneros. Como observamos anteriormente, não é uma boa atitude imaginar que os gêneros têm uma relação biunívoca com formas textuais. (....) Assim, em muitos casos, apenas o local em que um texto aparece permite que determinemos com alguma precisão de que gênero se trata.

Em geral, damos nomes aos gêneros usando um desses critérios:

\begin{tabular}{|c|c|}
\hline $\begin{array}{l}\text { 1. forma estrutural (gráfico; roda-pé; } \\
\text { debate; poema) }\end{array}$ & $\begin{array}{l}\text { 4.meio de transmissão (telefonema; } \\
\text { telegrama; e-mail) }\end{array}$ \\
\hline $\begin{array}{l}\text { 2.propósito comunicativo (errata; } \\
\text { endereço) }\end{array}$ & $\begin{array}{l}\text { 5.papéis dos interlocutores (exame } \\
\text { oral; autorização) }\end{array}$ \\
\hline $\begin{array}{l}\text { 3. conteúdo (nota de compra; resumo } \\
\text { de novela) }\end{array}$ & $\begin{array}{l}\text { 6. contexto situacional (conversação } \\
\text { esp.; carta pessoal) }\end{array}$ \\
\hline
\end{tabular}

Mas vários desses critérios podem atuar em conjunto. Basta ver os nomes que encontramos para os mais variados gêneros para imediatametne constatar que na constituição do nome sempre atua mais de um critério. Mas o certo é que quando se tem algum problema ou conflito na designação, ela surge em atenção ao propósito comunicativo ou função. (MARCUSCHI, 2008, p. 164)

Embora o caráter operacional desses critérios seja abrangente e permita o desenvolvimento das classificações, eles podem levar mais uma vez ao predomínio das formas composicionais para determinar o que são os gêneros poéticos. Como equilibrar essas abordagens?

O deslocamento da questão para "onde", deixando o "como" para uma segunda etapa se apresenta como resposta. O equilíbrio das concepções de gênero se funda nos objetivos de aplicação. Se a questão é a discussão acadêmica, a abordagem bakhtiniana responde às necessidades dos gêneros poéticos e atende às expectativas geradas na esfera literária, em que 
a discussão aberta pelo elemento definidor, a visão hegemônica do mundo instaura uma suficiência para discussões subsequentes. O mesmo não é possível, quando o objetivo se volta para a aplicação em sala de aula. Como ensinar gêneros cujos elementos de contato imediato confundem a percepção do leitor?

Uma das saídas é compreender que a concepção de discurso poético como elabora Bakhtin se refere a uma macrodiscussão. Necessária e suficiente para a esfera acadêmica, sendo aplicável a enunciados em que nem mesmo a combinação de critérios pode determinar qual o gênero, se poético ou não. No entanto, para o trabalho em sala de aula, devido às sucessivas mediações que ocorrem até o encontro dos alunos (e um pouco menos para os professores) com os enunciados poéticos, o estudo das formas composicionais em relação imediata com as formas arquitetônicas parece oferecer percursos semelhantes aos vistos na esfera acadêmica, deslocados para a operacionalização em projetos de ensino.

Resgatar as formas arquitetônicas no estudo em sala de aula se apresenta como uma possibilidade para que, na esfera escolar, se recupere o trabalho com os gêneros na perspectiva discursiva, uma vez que essas

\begin{abstract}
são as formas dos valores morais e físicos do homem estético, as formas da natureza enquanto seu ambiente, as formas do acontecimento no seu aspecto de vida particular, social, histórica, etc.; (....) são as formas da existência estética na sua singularidade. (....) A forma arquitetônica determina a escolha da forma composicional (Bakhtin, 1924/1979, p. 25).
\end{abstract}

Estudar a relação entre as duas permite a assunção de um enfoque tripartido do gênero, ou seja, estudar tema, estilo e forma composicional. Significa abandonar a abordagem centrada apenas nas formas composicionais para assumir uma abordagem discursiva como propõe Padilha em sua tese Os Gêneros Poéticos em Livros Didáticos de Língua Portuguesa do Ensino Fundamental: uma abordagem enunciativo-discursiva (2005) que se assume aqui como desejável para a entrada e o trânsito do poema em sala de aula:

Por isso é que advogamos uma abordagem que abranja o enunciado poético de forma discursiva, atentando para os aspectos do seu processo de produção, para as dimensões sócio-históricas, mas também para os aspectos da forma composicional e para as escolhas lingüísticas que configuram o estilo autoral ou o estilo marcado pelo gênero.

Relembrando a confusão da estética material, apontada por Bakhtin (1924/1975), entre as formas arquitetônicas e as formas composicionais, afirmamos que, para o ensino do texto literário, do texto poético, o que se visa, ainda de maneira muitas vezes equivocada e incompleta, são as formas composicionais que realizam as arquitetônicas, e nunca se chega à consideração destas últimas, que só seriam desveladas na construção dos temas, no sentido bakhtiniano. Assim, uma 
organização do ensino dos gêneros poéticos como gêneros do discurso deveria prever um enfoque didático tripartido entre tema, forma composicional e estilo, e explorar de forma múltipla os múltiplos processos de (re) ssignificação promovidos nos textos em gêneros poéticos, através de leituras variadas, de textos significativos, de procedimentos intertextuais e interdiscursivos. (BARBOSA, 2005, p. 244)

Por essa razão, neste capítulo, a discussão sobre os gêneros poéticos se volta agora para a esfera escolar, quando se tornam objeto de ensino em sala de aula para que se torne possível que o aluno aprenda a ler e escrever esses gêneros.

\subsection{Então é possível aprender a ler e escrever poemas na escola?}

Ao tratar da poesia, assumi, neste trabalho (como até então tem-se feito), a denominação gêneros poéticos uma vez que a poesia é múltipla e o texto classificado como poema também o é. Estudar os gêneros poéticos significa colocar sob exame muitas formas historicamente marcadas (como o epigrama), renovadas com maior (como o soneto ou as canções) ou menor frequência (como os epitalâmios ${ }^{58}$ ), daí a preferência por uma classificação que permita o trabalho como um todo, envolvendo a estrutura composicional, o tema, suportes e espaços de circulação desses gêneros, na tentativa de se contrapor à alegação do professor de não apresentar

a poesia em suas aulas por não saber como proceder, além de afirmar que o referido gênero demanda tempo e paciência para ser trabalhado.(....) a escola se põe a ensiná-la a medir a sílabas, a grifar os substantivos do poema, a circular os verbos, a encontrar os dígrafos e por aí vai. (SORRENTI, 2007, p. 17)

Por essas costumeiras formas equivocadas de aproximação, o trabalho com os gêneros poéticos em geral se restringe à sua apresentação formal. $\mathrm{O}$ fato de o texto estar disposto em versos garante que o aluno e o professor se sintam diante de um poema. Isso implica, como indica Pelletier (apud Adam, 1985), que a poeticidade seja um efeito obtido pela aplicação sobre o texto de uma posição de leitura, culturalmente determinada, submetida a certa variação. Assim, se nos dizem que algo está em verso, indicamos nossa assunção desse fato ao assumirmos uma postura que guiará nossa relação com o texto diante de nós.

\footnotetext{
${ }^{58}$ Como o de Vinicius de Moraes, cf. http://www.viniciusdemoraes.com.br/poesia/sec_poesia_view.php?busca=Epital\%E2mio\&acao=buscar\&id=121

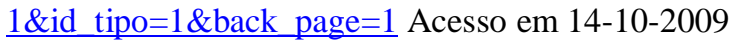


Por essa razão, tal como acontece hoje em dia na escola, os gêneros poéticos necessitam de estudos que o identifiquem, que confirmem, ou não, as intuições do leitor (professor ou aluno); que permitam o ensino e a descoberta (ou redescoberta) de um lugar do qual saímos ou para o qual nos dirigimos com a leitura da poesia. Não se trata de trazer à baila o caráter utilitário da poesia, mas de se utilizar o instrumental formal aliado ao estudo das vozes e dos discursos, em confronto, na voz centralizadora do poeta, retomando assim os vínculos dessas estruturas com os usos sociais e as formas relativamente estáveis que caracterizam esses gêneros.

Nesse caso, o investimento na formação do professor de Língua Portuguesa, representando a si mesmo como agente de letramento, cujo objeto seriam os gêneros parece ser uma perspectiva necessária. Buscando promover a construção dessa representação para que, além do limite do formal, ele possa combinar os conhecimentos e construir um gênero escolar (ou seja, um objeto de ensino) que possa utilizar realmente em situações de sala de aula.

\subsubsection{A poesia em 3D ou a poesia na realidade?}

O enunciado poético entra na escola como um objeto tridimensional, porém devido ao tratamento didático que lhe é dispensado, passa a ser uma sequência de lâminas que se sucedem formando uma imagem em 3D, que se mostra oca em seu centro. Para o professor, o resultado do alinhamento das sucessivas lâminas muitas vezes parece bastante razoável como leitura do objeto em si, pois, em sua formação nos cursos de graduação essa imagem, dada por outras instâncias legitimadas institucionalmente se colocou entre ele e o poema real. No entanto, para o aluno, que recebe o texto poético sem essas mediações é a figura tridimensional (sem a reconstrução desse todo pelas lâminas em sequência, que poderiam ser identificadas com o estudo dos temas; estudo das figuras de linguagem; estudo do metro etc.) que estimulou sua percepção. A leitura que ele faz do objeto a sua frente resulta de representações de caráter imediato. Para ele, não haveria a necessidade de uma mediação. Por essa razão, quando o professor traz a imagem em 3D, oca em seu centro, o aluno perde a sensação do todo; não reconhece mais a existência do objeto ou então considera dois objetos, o real (para ele) e aquele resultado da mediação do professor. 
Essa rejeição acontece porque o aluno não tem elementos suficientes para o que Martins, retomando a obra de Dámaso Alonso (1989, p. 9), aponta como o segundo modo de compreensão de uma obra: o do crítico, que "transmite suas reações de modo criativo e poético, sem explicar o como e o porquê da produção da obra". O aluno estaria no primeiro modo: "o do leitor comum, que não procura analisar nem exteriorizar suas impressões. É uma intuição totalizadora, que se forma no processo da leitura (....)" (MARTINS, 1989, p. 8-9). "Esta leitura", ressalta Martins a respeito desses modos de compreender a obra literária apresentados por Dámaso Alonso, “cujo objetivo primário é o prazer, é o fundamento das outras espécies de conhecimento." (MARTINS, 1989, p. 9). Um dos nossos objetivos na escola é recuperar essa primeira leitura do texto poético em outras leituras posteriores que permitissem a compreensão dos vários gêneros poéticos. Assim uma das questões a serem respondidas antecede a primeira etapa de inserção desses gêneros: "é possível ler poema na escola?" Uma das respostas dadas por Paulino (et alli, 2001, p. 85) não considera a factibilidade da leitura, mas as condições de produção dessa leitura: "um dos determinantes do modo de ler tem sido os gêneros de textos. Eles têm caráter histórico, relativo, mas nunca estão ausentes da constituição textual e por isso devem ser levados em conta no momento da leitura."

Quando um dos gêneros poéticos é trazido para o foco do trabalho em sala de aula, enfrenta-se de forma crucial essa tensão que alia o diálogo das vozes presentes no poema com o tecido formado pelos elementos estruturais dentro da temática que os sustenta. Trata-se de optar por uma educação mais ampla de cunho humanista, que se oporia à forma de ensino que vem sendo desenvolvido nos tempos atuais (ou principalmente agora) de forte caráter pragmático, que propaga uma posição velada, mas amplamente veiculada, de que "quase ninguém gosta de versos", e que "o mundo dos versos é fictício e falso." Embora muitos se envolvam com alguns dos gêneros poéticos, isso ocorre na esfera privada, fora dos muros da escola, e muitas razões podem ser apresentadas para justificar o descompasso entre o discurso e uma prática de caráter privado, ou seja, fala-se sobre o poema de forma a rejeitá-lo, mas lêse poema e gêneros afins. Uma delas resulta do artificialismo das propostas de trabalho com os gêneros poéticos.

Em decorrência da caracterização do gênero feita pela maioria dos professores e uma certa homogeneidade de textos trazidos para a sala de aula, o resultado do trabalho com os enunciados poéticos tem sido construir uma visão parcial e anacrônica das atividades de linguagem, porque embora os gêneros sejam estáveis, não são cristalizados. "São as 
dimensões partilhadas pelos textos pertencentes ao gênero que lhe conferem uma estabilidade de fato, o que não exclui evoluções, por vezes, importantes." (SCHNEUWLY e DOLZ, 2004, p. 75). A dinamicidade acontece pela dimensão individual, ou seja, cada enunciado desloca ou redimensiona o gênero. A tensão entre tradição e atualização permite esse desenvolvimento, ainda que isso ocorra de forma não programática, obedecendo às mesmas contradições e variações temporais às quais qualquer outra mudança sócio-histórica está submetida.

Surge desse dado outra razão para que se estude o gênero poético em sua multiplicidade e presença na realidade: o fato de ser possível substituir a noção de texto banal e inútil por uma visão mais abrangente e mais condizente com a plurissignificativa natureza do poema, pois permite deslindar, ainda, a presença do poético em outros gêneros, como o publicitário, cuja influência e cujo uso produz outros sentidos nem sempre abertos como os da poesia e que, por vezes, banalizam o poema, levando-o a ser considerado "perda de tempo" parecendo ao aluno que desconhece esses percursos que o processo é inverso, isto é, o poema é que retoma a publicidade. Como se observou no capítulo 2, elementos do gênero publicitário (ou o tratamento dado aos objetos nesse gênero) apareceram algumas vezes nos poemas do Pólo São Paulo, pois para os alunos louvar algo hoje em dia é torná-lo desejável como objeto de consumo. Reverter esse processo seria abrir a outros valores que não os mediados pela lógica do mercado.

Cronologicamente, como descreve Paulino (et alli, 2001, p. 86) e como já foi mencionado neste trabalho, a poesia nasce no meio do povo, acompanha e envolve suas atividades diárias, sendo retomada, atualmente, em alguns rituais "em que certos grupos de elite se reúnem, em saraus, para recitar poemas e discuti-los coletivamente.” Essas ações seriam um caminho de volta ao centro das atenções para o poema? Como o poema vive, hoje, num mundo sob o predomínio do discurso prosaico?

Nos sujeitos letrados, há passagens sempre renovadas dos gêneros poéticos primários para os secundários. Isso ocorre porque circulamos em esferas em que as diversas formas de organização convivem ou requerem nossa ação e deslocamento. Desde a infância, quando a criança ouve parlendas, jogos sonoros e cantigas, cujo intuito é diverti-la ou mesmo promover uma ação (como dormir), ela está em contato com textos orais, que constituem um repertório estreitamente ligado às atividades de linguagem que desenvolve. Ao longo da escolarização, as condições de produção vão se tornando complexas, bem como as formas 
composicionais presentes na materialidade do enunciado poético. A passagem de gênero primário a secundário estabelece o deslocamento do gênero das situações geradoras do passado, explicita uma necessidade e exige um esforço de compreensão muito maior por parte do leitor que, agora, deve identificar os processos linguísticos e discursivos responsáveis pelo afastamento, instaurados por formas composicionais mais complexas.

A estrutura na ação dos gêneros secundários (Bronckart apud SCHNEUWLY e DOLZ, 2004, p. 30), na nossa sociedade, "aos poucos afasta a poesia do cotidiano rumo às academias, tornando-se manifestação de uma elite cultural que se quer responsável pelo saber. Aí, então, o texto poético passa a ser propriedade de alguns, ficando inacessível à grande maioria." (PAULINO et alli, 2001, p. 87). Essa nova representação do gênero poético não permite, muitas vezes, a retomada do envolvimento espontâneo com a poesia, como gênero primário. Os sentidos derivados de prazeres cinestésicos, por exemplo, são reprimidos passando a serem aceitos de maneira mais imediata em outro gênero, como a canção. Nesse, é possível aceitar a complexidade das formas composicionais atuando como uma unidade, envolver-se com o enunciado de forma mais imediata, por meio de uma postura próxima àquela descrita por Dámaso Alonso, a da intuição totalizadora. O contato e eventual trabalho com a canção, nesse caso, permite que o aluno aceite o duplo propósito da atividade de leitura proposto pelo professor: "por um lado, um propósito didático: ensinar certos conteúdos constitutivos da prática social da leitura, com o objetivo de que o aluno possa reutilizá-los no futuro, em situações não didáticas. Por outro lado, um propósito comunicativo desde a perspectiva atual do aluno.” (LERNER, 2008, p. 80) Por que é diverso com o poema? Qual o papel da circulação em certos "campos" para que o poema se afaste dos alunos?

Por não ser um objeto de consumo imediato e, muitas vezes, não estar na ordem das trocas comerciais (posição inversa daquela das canções), os gêneros poéticos passam, hoje em dia, por uma situação particular, como assinala Paulino (et alli, 2001, p. 85):

Trata-se de um tipo de texto que tem circulação restrita na sociedade atual, embora haja tentativas de resgate de suas origens populares através de saraus e jograis, cantadores e repentistas e da própria musicalização dos poemas. Além disso, há mesmo uma tentativa de atualização de linguagens quando na Internet, por exemplo, criam-se textos poéticos em movimento. (.....)

A importância do resgate dos gêneros poéticos não se encontra no uso de novas linguagens, embora sempre haja espaço e vocação nesses gêneros para essas "atualizações”. A questão central é romper com a representação de um gênero de elite, possibilitando aos 
gêneros poéticos secundários a oportunidade de circularem e serem "consumidos" (lidos) em outros suportes, com ou sem intervenção do propósito didático. Essas novas situações ocorrem, a todo momento, enquanto escrevo esse parágrafo, leio a notícia sobre o projeto POESIA NO METRÔ, inaugurado no dia 20-10-2009:

O projeto utilizará espaços públicos para difundir a arte e provocar nos usuários o interesse pela leitura. Os textos ficarão expostos, durante três meses, no interior das estações e nos seis trens novos que estão em circulação. Trata-se de adesivos em tamanhos grandes, para serem lidos mesmo a distância. ${ }^{59}$

Esse novo trânsito é uma tentativa de $\operatorname{suprir}^{60}$ as lacunas encontradas nas formas clássicas de movimentação do poema, naturalizando os contatos, pois mesmo em áreas em que a produção poética vem crescendo como na literatura infantil, ainda é pequena a publicação. Sorrenti afirma que "o fato pode ser percebido no mercado editorial. Percorrendo as páginas de um catálogo de editora, número de títulos de poesias é mínimo, comparado àqueles de narrativa em prosa. Os editores alegam que publicam pouco porque 'poesia não vende"” (SORRENTI, 2007, p.21)

Envoltos nessa aura ainda pouco favorável, os gêneros poéticos chegam à escola com rótulos pouco meritórios, sendo necessária uma quebra dessa representação para que se possa efetivamente realizar um trabalho produtivo.

\subsubsection{Representações dos gêneros poéticos, indo além dos versos}

Para prosseguir na análise das representações dos gêneros poéticos e nos elementos que as constituem, é necessário o retorno às noções de representação social presentes na nossa vida cotidiana como constitutivas de ação posterior:

Segundo a perspectiva da teoria das representações sociais, se um indivíduo expressa uma opinião sobre um objeto ou uma situação, esta os constitui. Uma vez que se desfaz a ruptura sujeito-objeto, toda a realidade é representada, individual e coletivamente: ela é reconstruída no sistema cognitivo e integrada no sistema de valores socioculturais, históricos e ideológicos. (....) São sistemas ao mesmo tempo motivadores e justificativos da ação. (KLEIMAN, 2006, p. 79)

\footnotetext{
${ }^{59}$ Disponível

em http://www.metro.sp.gov.br/aplicacoes/news/tenoticiasview.asp?id=65654J67BD\&categoria=6540CF\&idioma= PO\&secao=ACONTECENDO Acesso em 21-10-2009.

${ }^{60}$ Mesmo que saibamos da dificuldade de certas camadas sociais para uma inclusão digital efetiva.
} 
A mudança de representação, em sala de aula, poderia começar por novos encontros com o poema. Dentre alguns pontos a serem revisitados, um dos primeiros (presente em alguns trechos das oficinas do Prêmio) é o combate à concepção de que existe uma ideia e o poeta, em momento posterior, a recobre de palavras. Esse tipo de representação leva invariavelmente a um equívoco: a noção de suficiência dos recursos poéticos - figuras de linguagem de som, de construção, de palavra, de pensamento, rimas, metros etc, para se criar e se compreender o enunciado poético. Admitir que existe um conceito e depois uma espécie de adorno ou forma que o envolve seria ignorar o papel da linguagem no discurso literário, como também o papel desse discurso. Embora Drummond tenha afirmado (apud BERALDO, 1990, s.p.) sobre a questão da inspiração e da capacidade de comunicação de um poema que

o que faz com que uma pessoa desconhecida que mora no Piauí escreva para gente uma carta dizendo: 'Olha, eu li um poema seu, estava angustiada, estava desesperada; seu poema é doloroso, é angustioso, mas ele me faz bem' (...) A pessoa sentiu-se confortada porque viu que um outro ser humano já experimentou aquela situação e conseguiu transmitir em verso.

o que a pessoa do Piauí sentiu, ao ler, não foi sua angústia nem a primeira angústia drummondianna (que Pessoa já alertou que pode não ser do poeta) foi a junção desses sentimentos humanos a uma transfiguração dada pelas formas arquitetônicas ${ }^{61}$ desse dizer no gênero. A angústia do poema não existe senão nesse espaço, mas ao recriá-las pela leitura, aceitando os movimentos propostos pelo poeta, o leitor (a pessoa do Piauí) tem a ilusão de reconhecer sua angústia inscrita nos versos.

Isso ocorre por terem os gêneros poéticos, como parte do gênero literário, uma característica principal que é fundar seu referente como interno. Essa característica acaba por traçar relações com o referente externo que, por vezes, acontecem com total adesão - o depoimento de Drummond assim nos revela. Em outros contatos com o poema, porém, essas relações parecem não acontecer - o texto se apresenta, nesse caso, como um enigma - ou ainda, em outra situação de leitura, as relações são qualificadas como banais - para o leitor -, porque o texto adere de tal forma à realidade que é insuficiente para cumprir o papel ou a representação esperada para uma forma do gênero literário.

Esses são os casos (extremos como, em geral, são os exemplos) de poemas como os de Augusto dos Anjos ou de Alphonsus de Guimaraens (ainda que não compartilhem

\footnotetext{
${ }^{61}$ Cf. p. 132.
} 
experiências estéticas). Os poemas escolhidos para essa exemplificação são "Plenilúnio" ${ }^{62}$ e "Ismália"63 que circulam nos livros didáticos de literatura como exemplares de uma concepção estética e das características do estilo desses poetas.

Esses enunciados poéticos parecem exigir do leitor uma espécie de colaboração que, na maioria dos casos, estaria além das possibilidades dele. A sensação que o leitor médio tem é de que ele precisaria ser um crítico para poder entender o poema. Por essa razão, não vê sua "utilidade". Para que escrever um poema sobre a lua ou sobre a mulher aparentemente privada da razão?

A estrutura composicional, em ambos os casos, se coloca como barreira para a leitura, rompendo com a ideia de uma fruição imediata presente em outros textos em que os sentidos são oferecidos (penso no texto publicitário; as novelas televisivas para um público juvenil; artigos de jornais e revistas para essa mesma faixa etária e afins). Isso decorre da construção de retóricas e ritmos que cada época produz e que a caracteriza. Muitas vezes, essa é a razão para perguntas como: “Qual a função desses poemas?” Não se trata, nesses versos, de discutir a supressão de sentimentos com os quais poderia o leitor se identificar, pois eles estão presentes. O que se apresenta, no entanto, nesses textos poéticos é a construção do tema de uma outra perspectiva discursiva, em outra estética que pouco se aproxima dos gêneros primários utilizados, muitas vezes, como base para a relação com o enunciado poético pelos leitores. É uma proposta de outra esfera cultural que necessita de um tipo de aprendizado para que possa ser fruído de maneira mais completa. Primordialmente e, em outros casos, exclusivamente, esse aprendizado ocorre na escola.

Por outro lado, existem poemas revestidos de uma aparente simplicidade, que dão ao leitor a impressão de brotar da fala do cotidiano, de serem "fáceis", por essa razão a eles não é atribuído um grande valor. "Qualquer um poderia ter escrito" ou "Não parece poesia" são as frases que o professor ouve com maior frequência em relação a esses poetas que rompem

\footnotetext{
${ }^{62}$ Plenilúnio// Desmaia o plenilúnio. A gaze pálida/ Que lhe serve de alvíssimo sudário/ Respira essências raras, toda a cálida/ Mística essência desse alampadário.// E a lua é como um pálido sacrário,/ Onde as almas das virgens em crisálida/ De seios alvos e de fronte pálida/ Derramam a urna dum perfume vário.// Voga a lua na etérea imensidade!/ Ela, eterna noctâmbula do Amor,/ Eu, noctâmbulo da Dor e da Saudade.// Ah! como a branca e merencórea lua,/ Também envolta num sudário - a Dor,/ Minh'alma triste pelos céus flutua! Disponível em http://www.revista.agulha.nom.br/augusto12.html Acesso dia 20-11-2009.

${ }^{63}$ Ismália// Quando Ismália enlouqueceu,/ Pôs-se na torre a sonhar.../ Viu uma lua no céu,/ Viu outra lua no mar.//No sonho em que se perdeu,/ Banhou-se toda em luar.../ Queria subir ao céu,/ Queria descer ao mar...// E, no desvario seu,/ Na torre pôs-se a cantar.../ Estava perto do céu,/Estava longe do mar...//E como um anjo pendeu/As asas para voar.../Queria a lua do céu,/ Queria a lua do mar...//As asas que Deus the deu/Ruflaram de par em par.../ Sua alma subiu ao céu,/ Seu corpo desceu ao mar...

Disponível em http://www.releituras.com/alphonsus_ismalia.asp Acesso em 20-11-2009.
} 
com certo isolamento formal, apresentando fortes traços do registro coloquial. Novamente a ação desses poemas parece perdida e não necessária para os leitores que não conseguem situá-los em uma representação anteriormente prescrita para eles pelos institutos legitimadores como a escola ou, ainda, a programação mais popularesca dos meios de comunicação como a da televisão. O cenário desses enunciados poéticos e a lógica subjacente a todos eles não pode ser compreendida de fora, assim, as formas composicionais fornecem as direções para o acesso a eles. Trata-se de poemas de autores modernistas como Manuel Bandeira e Fernando Pessoa (Alberto Caieiro), (os leitores em geral apagam a diferença temporal e estética entre eles), respectivamente "Porquinho da índia" e "Um dia de chuva é tão belo como um dia de sol"; ou ainda mais próximos da contemporaneidade, como Cacaso e Francisco Alvim - como "Um homem sem profissão" e "Mas", que comento, indicando os vínculos com essas representações.

Um dia de chuva é tão belo como um dia de sol.

Ambos existem; cada um como é.

O poema de Caieiro apresenta estrutura simples, formada por dois períodos. No primeiro (período simples), o enunciador afirma em avaliação axiológica: a assunção da beleza de dois elementos, o dia de chuva e o dia de sol. Essa premissa, que pode ser considerada maior, é validada por uma formação discursiva, cujo cerne é a aceitação da natureza e do que existe como valor central da experiência, e passa a ter um valor de verdade a partir do verbo que indica existência: "ser". No segundo período, há duas orações coordenadas assindéticas. A justaposição desses períodos promove uma espécie de finalização do silogismo, a apresentação da premissa menor e da conclusão, respectivamente "ambos existem";“"cada um como é”. A reafirmação, nos versos, da existência como fonte da verdade, elemento central da argumentação, promove o poema a espaço de discussão filosófica numa posição paradoxal se se considerar que Caieiro nega essa via de acesso ao conhecimento, pois, em outro poema, afirma: "Pensar é estar doente dos olhos".

Assim, nesse poema - silogístico na forma e paradoxal pragmaticamente pela posição de Caieiro -, é possível observar matrizes de pensamento que só podem ser desvendadas num

\footnotetext{
64 do livro Poemas Inconjuntos, In PESSOA, Fernando. O Eu profundo e os outros eus: seleção poética; seleção e nota editorial de Afrânio Coutinho. Rio de Janeiro: Nova Fronteira, 1980, p. 177
} 
mergulho dentro do poema e da reconstituição da concepção de mundo do poeta. O que de acordo com Bakhtin é o que constitui o caráter monológico da poesia, mas construído, neste caso, sem a tensão das redes de coincidência sonora ou sintática, em uma emulação do pensamento do homem comum, envolvido pelo mundo, que acaba por produzir tautologias aparentes, negadas pelos alunos que as lêem como formas sem sentido ou formas simples demais para fazerem parte do gênero poético.

O segundo poema, "Porquinho da Índia", enfrenta outro tipo de rejeição: a estrutura composicional aparentemente simples numa voz simulada de criança leva o aluno a dizer: "se fosse eu que tivesse escrito...", para indicar que o professor é um consumidor de "grifes literárias", não conseguindo distinguir o que é bom e o que é, portanto, ruim senão por meio da etiqueta.

\title{
PORQUINHO-DA-ÍNDIA ${ }^{65}$
}

\author{
Quando eu tinha seis anos \\ Ganhei um porquinho-da-índia. \\ Que dor de coração me dava \\ Porque o bichinho só queria estar debaixo do fogão! \\ Levava ele prá sala \\ Pra os lugares mais bonitos mais limpinhos \\ Ele não gostava: \\ Queria era estar debaixo do fogão. \\ Não fazia caso nenhum das minhas ternurinhas . . . \\ — O meu porquinho-da-índia foi minha primeira namorada.
}

Muitas vezes, o aluno não consegue ir além da forma mais imediata, colocando de lado a questão enunciativa. Como não investe na leitura das vozes presentes no poema (ou não consegue escutá-las), ele sentencia que o texto é simples porque o enunciador não é competente. Sabe-se, no entanto, que escrever como uma criança (ou pintar como uma delas) é muito difícil e requer uma compreensão de mecanismos provavelmente perdidos ou apagados da memória. Em "Porquinho da Índia", há dois tempos enunciativos mesclados, aquele da infância e o momento presente de onde o enunciador fala. No presente do enunciador, surge a fala final, "O meu porquinho-da-índia foi a minha primeira namorada" como uma forma de encontrar sentido nas relações amorosas atuais tão difíceis e tão frustantes como aquela primeira. Para se compreender o homem no menino que se apresenta no poema, é preciso, no entanto, aceitar o pressuposto que implica uma analogia simples: se o

\footnotetext{
${ }^{65}$ Do livro Libertinagem, In BANDEIRA, Manuel. Estrela da Vida Inteira. 19 ${ }^{\mathrm{a}}$ ed. Rio de Janeiro: Jose
} Olympio, 1991, p. 100. 
porquinho da índia é a primeira namorada e tinha esse comportamento, todas as outras que vieram depois também tiveram o mesmo comportamento. Rejeição e frustração, portanto, existem, no poema, cercadas por delicadezas e formas infantilizadas de entender o mundo. Ao tratar do passado, o enunciador encontra no diminutivo ("bichinho", verso 4; "limpinhos", verso 6; "ternurinhas", verso 9) e no uso de elementos da variante coloquial (marcada nos usos de pronomes pessoas do caso reto na posição de objeto: "Levava ele", verso 5 ; e o uso de formas de ênfase: "Queria era estar de baixo do fogão", verso 8; e contrações típicas da oralidade: "Pra os lugares mais bonitos mais limpinhos), um modo de intervir nesse passado justificando seus atos numa espécie de gratuidade que redime a todos envolvidos.

Diante da relação intrincada de elementos que transitam da infância até a idade adulta, como apresentar esse poema para crianças, por que falar de bichinhos de estimação, quando o poeta quase chega a falar de masoquismo nas relações amorosas, por questões de auto-estima e afetividade truncadas.

Ainda na questão enunciativa, outro exemplo é o poema de Francisco Alvim:

$$
\begin{aligned}
& \text { MAS }^{66} \\
& \text { É limpinha }
\end{aligned}
$$

O único verso ("é limpinha") adere ao título "Mas", levando-nos a reconstruir uma voz que podemos considerar alheia ao poeta, mas não ao seu ouvido. Essa voz, esse outro, nos apresenta uma formação discursiva, a do preconceito racial. O poeta, ao trazer o preconceito para o espaço do poema e deixá-lo pairar sem uma negação ou aprovação, emula as vozes que circulam entre nós? Questionar como é possível entender essa presença diversa de outras vozes nos poemas circundantes e identificar os elementos que não são dados - o porquê desse silenciamento também se coloca como necessário. Há trabalho para ser feito e o poema se instaura como o lugar em que nada ainda está fechado, o leitor precisa entrar e descobrir. Como no mundo que o cerca, o leitor é chamado a tomar uma atitude, indicar sua posição. Esse poema é talvez o exemplo limítrofe das questões da monologia, pois o enunciador, nesse caso, abre espaço como o narrador no romance para que as vozes se apresentem como realmente são, sem filtros. A leitura de "Mas" pode implicar também a

\footnotetext{
${ }^{66}$ Do livro Elefante, In ALVIM, Francisco. Poemas [1968-2000]. São Paulo: Cosac \& Naify; Rio de Janeiro: 7 Letras, 2004, p. 62.
} 
busca de outra postura na leitura do poema, e, provavelmente, em função disso, a rejeição a esses poemas por serem classificados pelo leitor como "nada" é imediata.

Por fim, o último poema a ser apresentado, nesse intervalo criado para discutir como as representações se instauram entre o aluno e o gênero, é "Um homem sem profissão", de Cacaso.

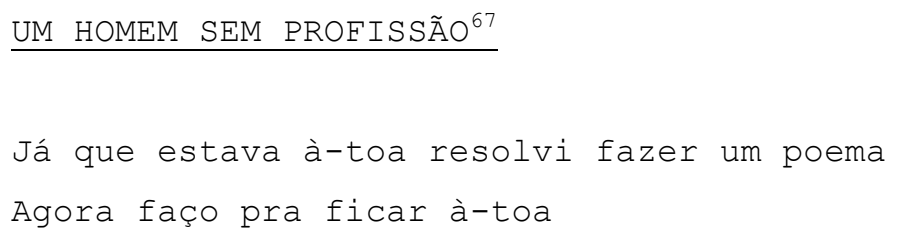

A banalização da poesia no primeiro verso se torna modus operandi do homem no segundo, indicando que as relações de implicação existentes entre o ato de escrever o poema e estar à-toa estavam instituídas dessa forma para os outros e não, para o enunciador. "Ficar à-toa", "contemplar a vida" pode ser o que o homem busca. Sair da rotina e encontrar fora do mundo do trabalho razões e ritmos de vida parecem ser questões centrais a partir de movimentos como o "Flower Power", entre tantos, que buscam outros modos de vida fora da esfera capitalista. $\mathrm{O}$ enunciador, no texto, aponta, no entanto, para o fato de que, ao fazer poemas, encontrou uma finalidade para a sua vida, por isso, parece não existir um retorno ao estado inicial, porque agora o enunciador sabe a razão de estar à-toa e de viver de acordo com essa perspectiva. Trata-se quase de uma poética, da chamada poesia marginal, em que a assunção de uma imagem de espontaneidade, sugeria como no estilo punk de tocar rock, que qualquer um podia ler e escrever poemas. Libertador e provocador ao mesmo tempo, esse posicionamento dialoga com o tempo do enunciador não podendo ser entendido como a negação do gênero poético como atividade de vagabundos. São vozes que se explicitam, em confronto, ora em um grupo de leitores, ora em outros, possibilitando ao professor (ou a um leitor que gerencie vivências relacionadas a essas representações) compreender e fazer compreender que os gêneros poéticos são filtrados continuamente por essas concepções que moldam nossas formas de dizer não aos poemas.

\footnotetext{
67 do livro Na corda bamba, In BRITO, Antônio Carlos de. Cacaso: lelo-lero [1967-1985]. São Paulo: Cosac \& Naify; Rio de Janeiro: 7 Letras, 2002, p. 57. O uso da fonte Courier New é uma tentativa de trazer a forma como foi editado e reproduzido em caderno avulso como parte dessa edição, provavelmente para mostrar ao leitor como eram os alguns livros da época (mimeografados).
} 
As razões para a refutação de poemas de certas concepções estéticas ou de épocas mais próximas do leitor estão no tipo de ação permitida ou atribuída para o enunciado poético, que se desenvolveu ao longo desses anos. O leitor, em geral, tem uma representação do gênero que envolve, por apresentar uma longa tradição, certos elementos identificados numa forma composicional. Os elementos que compõem essa estrutura parecem se constituir como chave para a leitura de todos os poemas, mesmo que não se encaixem no objeto a sua frente, razão pela qual muitas vezes o leitor não o enxerga. Um desses casos pode ser observado nos poemas dos alunos em que a disposição gráfica em versos e as rimas pareciam suprir as necessidades da forma composicional. O trabalho sonoro das rimas (mas não exclusivamente com elas) era o traço comum que sustentava a representação daqueles alunos.

Ao sublinhar as formas composicionais, perde-se o caráter discursivo dos gêneros poéticos, banalizando o poema como capricho ou exercício privilegiado de certos artistas. Substituir paradigmas implica esquecer as técnicas da poesia para não negar a ideia de gênero e homogeneizar o que é diverso.

Quais seriam os gêneros poéticos? O soneto, o rondó, o vilancete, os madrigais, as canções, os epigramas, o carmen figurata, o cordel, as quadras populares, as trovas, o haicai, a tanka, a ode, o auto, o poema de verso livre? Seriam só esses? A produção cultural do discurso poético se desdobra em muitos gêneros que devem ser estudados quanto às suas esferas sociais de circulação, ao estilo do gênero, à estrutura composicional, ao estilo do enunciado, ao tratamento dado ao tema, às relações entre esse enunciado e outros, ao diálogo entre as vozes presentes no enunciado.

Nos agrupamentos ou propostas de agrupamentos para o ensino dos gêneros, observase na indicação dos gêneros poéticos a singularização do "poema" na esfera do literário, mesmo que isso não ocorra nas esferas $\operatorname{privadas}^{68}$, há quadrinha, parlenda, trava-língua e adivinha (esse último pela tradição em sua gênese pertence ao gênero poético - cf. JOLLES, 1976)

\begin{tabular}{|l|l|}
\hline ESFERAS SOCIAIS DE CIRCULAÇÃO & $\begin{array}{l}\text { EXEMPLOS DE GÊNEROS ORAIS E } \\
\text { ESCRITOS }\end{array}$ \\
\hline ESFERAS PRIVADAS & $\begin{array}{l}\bullet \text { quadrinha } \\
\text { parlenda }\end{array}$ \\
\hline
\end{tabular}

\footnotetext{
68 Segundo Barbosa, gêneros da esfera privada são "gêneros primários que circulam em esfera cotidiana, familiar e foram apropriados pela escola. Como nosso enfoque principal são as esferas públicas, adotamos a solução de reuni-los num único agrupamento. Mas certamente, propostas de reagrupamentos desses gêneros seriam bem produtivas e esclarecedoras.” (2001, p. 48, rodapé 33)
} 


\begin{tabular}{|c|c|}
\hline & $\begin{array}{ll}\text { - } & \text { adivinha } \\
\text { - } & \text { trava-língua } \\
\text { - } & \text { piada } \\
\text { - } & \text { receita } \\
\text { - } & \text { diálogos } \\
\text { - } & \text { relatos de experiências vividas }\end{array}$ \\
\hline LITERÁRIA & $\begin{array}{ll}\text { - } & \text { poemas } \\
\text { - } & \text { conto popular } \\
\text { - } & \text { conto maravilhoso } \\
\text { - } & \text { lenda de fadas } \\
\text { - } & \text { fábula } \\
\text { - narrativa de aventura } \\
\text { - narrativa de ficção científica } \\
\text { - narrativa de enigma } \\
\text { - } \text { romance noir } \\
\text { - crônica literária } \\
\end{array}$ \\
\hline
\end{tabular}

(....) (BARBOSA, 2001, p. 48)

Embora Barbosa (2001) aponte no capítulo 3 "Considerações sobre o estabelecimento de progressões e de propostas curriculares" que o quadro de agrupamentos por esferas ${ }^{69}$ ainda é um primeiro passo a ser colocado em discussão, acrescentando que seria necessário adicionar o critério "finalidade ou objetivo do enunciador/autor, tendo em vista a posição que ocupa na esfera em questão", a divisão apresentada em relação aos gêneros poéticos não é muito diferente de outras com preocupação teórica semelhante. Por essas semelhanças, é possível identificar que existem alguns desequilíbrios significativos, provavelmente resultantes da impossibilidade de se fundar uma operacionalização imediata a partir da maneira como os gêneros poéticos são inseridos na esfera, tendo então que se recorrer à tradição das classificações circundantes, como as da tradição da esfera literária.

Inserir alguns gêneros nas esferas privadas e um único agrupamento na esfera literária sob a denominação "poema", mesmo supondo que as esferas privadas também sejam múltiplas, parece reunir toda a variedade dos poéticos secundários pelas formas composicionais, acentuando como é complexo determiná-los principalmente a partir de enunciados que rompem com o "isolamento" apresentando relações intergenéricas em outras esferas. Há, assim, dois percursos resultantes: fixar essa divisão (ou algo bastante similar) como uma posição na esfera literária, pela adoção de classificações mais tradicionais (que circulam pela escola - o uso das formas composicionais) ou estabelecer novas nomenclaturas (e consequentemente suas concepções) para os gêneros que circulam hoje em dia. Ambos se

\footnotetext{
${ }^{69}$ No quadro, há 9 esferas: Privadas; Literatura; Ciências; Escola; Imprensa; Publicidade; Política; Jurídica; e Produção e consumo (BARBOSA, 2001, quadro às páginas 48 e 49).
} 
inserem em modos de produção de conhecimento validados socialmente, mas pertencentes a perspectivas cujo ponto de partida não está no mesmo plano. Bazerman indica o porquê:

\begin{abstract}
Nos estudos literários, a visão moderna de gêneros evoca uma tradição antiga de avaliar os trabalhos de acordo com as suas espécies, tradição que remonta a Aristóteles, mas que nos séculos XVII e XVIII se tornou moribunda dentro de uma versão normativa de decoro artístico. A rejeição romântica dessa tradição, em nome de uma expressão individual, da originalidade e da unidade orgânica, bem como o caos aí dentro instalado aumentaram o estigma desses trabalhos denominados genéricos. Mesmo entre os críticos literários que s uperaram tais estigmas, os estudos literários continuam se preocupando, conforme a tradição, com um número limitado de gêneros literários que já estão encaixados dentro das práticas e dos pressupostos do sistema literário, de sorte que o pensar sobre gênero é mais adaptado para o poema lírico do que para as histórias em quadrinhos; mais para essas últimas do que para um relatório sobre impacto ambiental. (BAZERMAN, 2006, p. 25)
\end{abstract}

Os responsáveis pelo primeiro percurso estão dados. Quem seria(m) o(s) responsável(is) pelo segundo percurso? Os professores? Ou atores de outra esfera? Os pesquisadores?

A pesquisa em relação aos gêneros não está incluída entre as tarefas do professor. Como ele poderia sair de seu lugar de educador e assumir um lugar de pesquisador? Trata-se de esferas de atuação diversas, mas ainda permanece no campo de ação do professor a busca da agência mais completa em relação às atividades didáticas. Como essas atitudes poderiam ser realizadas nessa perspectiva?

A agência que o docente pode exercer em sala de aula está envolta por uma instável construção de conhecimento e instâncias de legitimação desse conhecimento ${ }^{70}$. No Prêmio, essas ações estão representadas na leitura crítica do material feita pelo professor, antes do momento da apresentação das atividades para as turmas; modificando ou adaptando-o para a realidade de sua sala de aula, como no caso (recuperado pelos relatos) das professoras de Bariri ("Bariri, bem te vi”) e Santo Anastácio ("Desabafo"). Em ambos os casos, embora de natureza diversa, o olhar atento do professor e sua ação permitiram que os alunos se envolvessem com as atividades que, a princípio, não pareciam interessantes ou necessárias, tal como Bazerman anuncia:

Cabe a nós, professores, ativarmos o dinamismo da sala de aula de forma a manter vivos, nas ações significativas de comunicação escolar, os gêneros que solicitamos aos nossos alunos produzirem. Isso pode ser feito, tomando-se como base a

\footnotetext{
${ }^{70}$ A ação se dá nos diversos gêneros envolvidos desde a ementa, a publicação para a inscrição, planos de aula, programas de curso, material de apoio, os trabalhos dos alunos e as avaliações do professor.
} 
experiência prévia dos alunos com os gêneros, em situações sociais que eles consideram significativas, ou explorando o desejo dos alunos de se envolverem em situações discursivas novas e particulares, ou ainda tornando vital para o interesse dos alunos o terreno discursivo que queremos convidá-los a explorar. (BAZERMAN, 2006, p. 30)

$\mathrm{Na}$ perspectiva de trabalho com os gêneros, o professor deve escolher um dos poéticos, tomando como critério para escolha não somente a inserção anterior em currículos, mas também a familiaridade ou o desafio que possam trazer para os alunos. Depois da escolha, o professor precisa inseri-lo no plano de ensino (ou no projeto temático) para que encontre lugar no cronograma. Submeter esse plano de ação ao coordenador ou instância superior, obtendo o aval para implementá-lo. A seguir, para apresentar o gênero escolhido em sala de aula, deve produzir conhecimento a respeito dele. Legitimá-lo agora como "conhecimento a respeito de" nas reuniões com outros docentes e coordenadores que, muitas vezes, não possuem autoridade suficiente (nem conhecimento específico) para essa legitimação, pois nesse caso não se trata de um aval global, mas de uma certificação dentro da especificidade discursiva.

Estão cruzados, nesse momento, conhecimentos didático e específico. Lerner, ao tratar da importância do primeiro na formação do professor, indica percursos que sistematizou, a partir do planejamento de uma sessão de oficina de capacitação e que podem ilustrar quais são as perguntas que o professor precisa fazer a si mesmo para produzir esse conhecimento que será posto em atividade em sala de aula: "Realmente, nossas notas e registros mostravam que, ao planejar cada sessão de uma oficina, nós nos fazíamos perguntas similares às que costumavam nos fazer os professores, perguntas que não podiam ser respondidas apelando simplesmente para a psicologia ou para a lingüística." (2008, p. 105). Psicologia e linguística aqui se referem a conhecimentos específicos daquela oficina e podem ser transferidos para os temas com os quais o professor necessita trabalhar com sua sala. A autora descreve as questões que envolviam o processo com que ela se deparou e que podem ser transpostas para a preparação do professor:

Múltiplas discussões aconteciam na equipe até que chegássemos a definir a situação didática (o problema, a proposta, a consigna) que nos parecia mais adequada para que os professores aprendessem cada um dos conteúdos que queríamos ensinar-lhes (....)

A preocupação em determinar a forma mais adequada para comunicar os conteúdos aparecia não só no momento do planejamento como também da avaliação (...). (LERNER, 2008, p. 105-6) 
A reflexão feita por Lerner permite uma observação quanto às dificuldades, ao se estabelecer projetos ou planos de forma individual, mesmo que às vezes essa seja a condição que se apresenta ao professor. A etapa de legitimação da escolha do gênero poético, do material a ser utilizado e das estratégias a serem aplicadas em sala de aula se constitui como uma saída para que os pressupostos metodológicos e a abordagem adotada possam ser discutidos e reavaliados mesmo antes de entrarem em "ação".

Depois de ultrapassar essas etapas - cada uma correspondendo a um enunciado concreto em um gênero diverso preparado pelo professor (plano de aula ou projeto; material a ser utilizado em sala; formulários para registro das atividades; e outros auxiliares a essa situação, como debate) -, o gênero poético escolhido chegará à sala de aula.

Embora não seja o objetivo deste trabalho, antes de prosseguir, considero necessário indicar um obstáculo que se apresenta ao professor. Para o docente, há a necessidade de se conhecer os gêneros acadêmicos, os didáticos e, simultaneamente, aqueles com os quais vai trabalhar que provêm de diversas esferas de circulação social. Essa gama de gêneros aliada aos espaços de intersecção entre eles na ação do professor exige uma proficiência para a qual ele nem sempre está preparado e que pode interferir na transposição didática. É importante que o professor tenha consciência de que sua ação docente exigirá o domínio de vários gêneros provenientes de diferentes esferas, retirando assim o peso total de suas ações do conhecimento específico sobre o gênero com o qual vai trabalhar em sala de aula. Como afirma Matêncio sobre as concepções de língua(gem), que podem ser transferidas para conhecimentos específicos de outra esfera:

E se hoje se fala com tranqüilidade da variabilidade da língua e dos gêneros textuais, da multiplicidade de discursos, não se pode esquecer de que não há ainda uma reflexão sistemática e consistente acerca de como transformar os objetos de estudo produzidos no campo dos estudos da linguagem em objetos de ensino. (MATÊNCIO, 2006, p. 96)

Um dos gêneros que possibilitam a transposição didática e permitem o enfoque tripartido, é a sequência didática (SD) ${ }^{71}$. Por organizar o conhecimento a respeito do gênero e por apresentar-se como instrumento didático para o aluno, a SD, sempre inserida num projeto temático ou mais especificamente, um projeto de ação ("projeto de atividades complexas orientado para um objetivo preciso de certa amplitude: organizar uma visita, uma exposição, um espetáculo, participar de uma acão de grande porte (feira de ciências, salão, de escritos), publicar uma coletânea de poemas, receber correspondentes, arrumar o pátio....”, JOLIBERT;

\footnotetext{
${ }^{71}$ Como se observou na análise do material do Prêmio Escrevendo o Futuro. Sobre a SD, cf. p. 28.
} 
SRAÏKI, 2008, 32) permite que o professor, ao produzi-la ou adaptá-la para a sala de aula ${ }^{72}$, escolha como trabalhar com cada um dos elementos (tema, forma composicional e estilo), quanto tempo dedicará a cada um deles, como avaliará o conhecimento dos alunos em relação ao gênero estudado.

Os processos de focalização dos dados a respeito do gênero e a hierarquização dos conhecimentos sobre ele permitem ao professor minimizar um dos pontos mais frágeis de toda transposição didática: o artificialismo decorrente do modo como se insere o gênero no espaço escolar. Se se pensar nas notícias de jornal, nas receitas de bolo, nas bulas de remédio, nos boletins de ocorrência, ou ainda nas cartas do leitor, a recuperação dos espaços de circulação diminui esse artificialismo. Os alunos podem mandar as cartas para os jornais. Podem montar um jornal na internet ou no mural da escola. Podem ir à cantina ou qualquer outro espaço culinário e preparar a receita. Podem verificar se a bula está correta ou não, consultando um especialista. Podem auxiliar alguém em situações em que o boletim de ocorrência for necessário. Em todas essas ocorrências, cada um dos gêneros precisa superar os umbrais da sala de aula para que se efetive a ação. Ocorre o mesmo com os gêneros poéticos? Qual (is) é (são) o(s) seu(s) espaço(s) de circulação?

No caso dos poéticos, esses espaços apresentam uma característica particular como afirma Maingueneau:

\begin{abstract}
Quando se trata de criação literária, metáforas topográficas como as de "campo" ou "espaço" só têm validade entre aspas. Claro que o espaço literário faz, num certo sentido, parte da sociedade, mas a enunciação literária desestabiliza a representação que se tem normalmente de um lugar, algo dotado de um dentro e de um fora. Os "meios" literários são na verdade fronteiras. A existência social da literatura supõe ao mesmo tempo a impossibilidade de ela se fechar em si mesma e a de se confundir com a sociedade "comum", a necessidade de jogar com esse meio-termo em seu âmbito. (....) Enquanto discurso constituinte, a instituição literária não pode de fato pertencer plenamente ao espaço social mantendo-se antes na fronteira entre a inscrição em seus funcionamentos tópicos e o abandono a forças que excedem por natureza toda economia humana. Isso obriga os processos criadores a alimentar-se de lugares, grupos, comportamentos que são tomados num pertencimento impossível. (MAINGUENEAU, 2006a, 91-92)
\end{abstract}

As ações que cercam e representam o projeto sistematizado em sequências didáticas, nesse quadro de paratopia, se apresentam como instrumentalização produtiva ao professor, pois, nas atividades desenvolvidas, é possível discutir as fronteiras apontadas, sem que com

\footnotetext{
${ }^{72}$ Há algumas publicações que se encaixam nesse gênero (sequência didática) embora não existam muitos títulos. Um exemplo de vinculação explícita a essas concepções é a Coleção da editora FTD: Trabalhando com Gêneros do Discurso, cujos volumes abordam os gêneros receita, narrativas de enigma, cartas de reclamação e solicitação, contos de fadas, fábula e notícia.
} 
isso o gênero se artificialize, uma vez que ele é formado por fronteiras em cuja margem pode se situar o espaço escolar. A SD, nesse percurso, possibilita a junção de atividades por meio dos gêneros, como os saraus; os cantos de leitura, os espaços para dizer e apresentar poemas; a exposição em murais. Todas essas ações, algumas intergenéricas, tornam o espaço escolar, espaço de circulação do gênero poético mesmo que durante um período determinado. Destitui-se o "como se fosse" trazendo para a escola a legitimidade de "ser" um desses lugares. Atenua-se, também, o fato de a literatura ser "frequentemente escrita e lida em momentos de contemplação, aparentemente (mas de forma categórica) destacada das circunstâncias mais imediatas da vida, o caráter social do gênero torna-se menos visível." (BAZERMAN, 2006, p. 25)

Hoje, muitas vezes, o reconhecimento da escola como espaço legítimo para a circulação do enunciado poético é realidade. Há diferentes iniciativas, em vários níveis, igualmente efetivas em sua esfera. Dentre elas, o Prêmio e, contemporaneamente, a Olimpíada de Língua Portuguesa mostraram que essa circulação é possível. Ao lado da legitimação do espaço e dos agentes envolvidos (alunos, professores e comunidade fora da escola), surgem as possibilidades do ensino de um gênero que, muitas vezes, foi classificado como difícil de ensinar por causa da sua dependência do gênio, de um talento acima da média tanto para interpretar quanto para escrever um poema em sala de aula. Dessa maneira, retirase do aluno a impressão de que não pode escrever porque não consegue atingir um padrão dado pela escola, mas "executado" (por assim dizer) fora da esfera escolar. O projeto em sala de aula afasta-se do ônus da tradição, que

pode parecer muito pesado para os alunos iniciantes e, até mesmo, para as pessoas
mais escolarizadas. A tradição dá muito valor a certos padrões de excelência. As
escolas, com razão, selecionam os melhores escritos para serem passados para as
próximas gerações. Afinal, quem iria passar algo de segunda categoria quando o
melhor está disponível? Em comparação, o pensamento e a escrita dos alunos
inevitavelmente parecerão fracos, incompletos e ineficazes. Nos Estados Unidos,
alunos e até adultos, ao explicar por que não escrevem dizem: "Eu não sou
Shakespeare. Eu não sou Hemingway. (BAZERMAN, 2006, p. 18)

Pode-se, nesse caso, instituir outras representações que tenham seu raio de ação ampliado, começando por incorporar a passagem do gênero primário para o secundário. Trazer uma certa fruição de sentidos, invocando o lúdico, pode ser uma primeira aproximação para os gêneros poéticos, mas não basta para sustentar a concepção de gênero poético dada a impressão de sua inutilidade ou de caráter pouco prático que é atribuído aos jogos ou ao lúdico, grande parte das vezes. 
Diante desse quadro, retorna a questão: se o empecilho não é o espaço de circulação, pois há propostas que legitimam espaço escolar para o trabalho com os gêneros literários, qual outro fator teria impedido o trânsito desses gêneros e, em especial, dos poéticos, na escola, relegando-os a um ensino singular durante muitos anos? Seria o repertório? O que o aluno precisa saber sobre o enunciado poético diante dele? O que o professor precisa saber?

Um pressuposto bastante inquietante para o professor é que hoje seu papel quanto aos temas a serem trabalhados em sala não está centrado na simples apresentação de informações. Os alunos têm acesso por vários meios (televisão, internet, celulares etc.) a dados que antes receberiam somente do docente. Nas informações vindas dessas mídias, porém, não existe nenhuma marca que indique qual a importância, relação ou a hierarquização entre elas. Esse é o papel central, e talvez o mais delicado, que o professor pode exercer: o de agente cultural. As aulas cujo foco são gêneros da esfera do literário em geral envolvem debates (que podem ocorrer ou não, em sala). Esses momentos de troca de ideias não gravitam somente sobre uma imagem ou uma personagem, referem-se a como foi dada a esses alunos a oportunidade de realizar projetos "mais pessoais", como afirma Lerner (2008, p. 80): "lêem-se muitos contos ou poemas, para escolher aqueles que se deseja compartilhar com outros leitores." A modalidade de leitura literária (o que se aplica ao poema) proporciona certa autonomia no ritmo e na forma de ler. "Quando o leitor se entrega à leitura literária, sente-se autorizado compensação - a se concentrar na ação e saltar as descrições, a reler várias vezes as frases cuja beleza, ironia ou precisão causam impacto, a se deixar levar pelas imagens ou evocações que a leitura suscita nele...” (LERNER, 2008, p. 81)

Esses "objetivos pessoais" estabelecidos na leitura e por ela suscitados, que nem sempre cabem no objetivo imediato da atividade (mesmo que seja importante reservar um espaço para eles), constituem um ponto de partida para a compreensão e reelaboração do repertório, podendo ser acrescentados aos instrumentos de avaliação.

A avaliação referente a propostas para o ensino dos gêneros discursivos estão envolvidas por uma outra questão subjacente ao ensino em processo: o tempo.

O que se trabalha e como se trabalha um gênero ou qualquer tema devem ser planejados, levando em conta os tempos da atitude responsiva, desdobrada na compreensão ativamente responsiva. Quando em contato com qualquer um dos gêneros circulantes, primários ou secundários, novos ou tradicionais, existe uma compreensão ativamente responsiva, porém, os gêneros são desigualmente propícios a "tal reflexo da individualidade 
do falante na linguagem do enunciado, ou seja, ao estilo individual." Os mais favoráveis são os da literatura - "aqui, o estilo individual integra diretamente o próprio edifício do enunciado, é um dos seus objetivos principais" (BAKHTIN, 2003, p, 265). Da mesma forma, a compreensão ativamente responsiva é requerida e se manifesta de diversas maneiras conforme o gênero com que se depara o ouvinte (leitor). $\mathrm{O}$ ato da leitura nesse caso específico é agência, tal como Bazerman a concebe, e permite retomar a idéia bakhtiniana de atitude responsiva (BAKHTIN, 2003), ou seja, desde a leitura, há um processo interpretativo e, nesse caso (dos gêneros artístico-literários), criativo, que finaliza a constituição do enunciado poético naquele sujeito que o lê.

Toda compreensão de uma fala viva, do enunciado vivo é de natureza ativamente responsiva (embora o grau desse ativismo seja bastante diverso); toda compreensão é prenhe de resposta, e nessa ou naquela forma a gera obrigatoriamente: o ouvinte se torna falante. A compreensão passiva do significado do discurso ouvido é apenas um momento abstrato da compreensão ativamente responsiva real e plena, que se atualiza na subseqüente resposta em voz real alta. É claro que nem sempre ocorre imediatamente a seguinte resposta em voz alta ao enunciado logo depois de pronunciado: a compreensão ativamente responsiva do ouvido (por exemplo, de uma ordem militar) pode realizar-se imediatamente na ação (o cumprimento da ordem ou comando entendidos e aceitos para execução), pode permanecer de quando em quando como compreensão responsiva silenciosa (alguns gêneros foram concebidos apenas para tal compreensão, por exemplo, os gêneros líricos), mas isto, por assim dizer, é uma compreensão responsiva de efeito retardado: cedo ou tarde, o que foi ouvido e ativamente entendido responde nos discurso subseqüentes ou no comportamento do ouvinte.Os gêneros da complexa comunicação cultural, na maioria dos casos, foram concebidos precisamente para essa compreensão ativamente responsiva de efeito retardado. Tudo o que aqui dissemos refere-se igualmente, mutatis mutandis ao discurso escrito e ao lido (BAKHTIN; 2003, p. 271-272)

Os tempos didáticos são tempos bastante restritos por responderem a uma ordem superior: a do plano de aula, a do projeto pedagógico, a do calendário escolar. Ao se tomar essa realidade como dado a ser considerado, pode-se mais claramente planejar, na sequência didática (ou na reunião delas em projeto de ação, os canteiros ${ }^{73}$ ), tempos diversos para gêneros de diversas compreensões ativamente responsivas. Quando o professor abordar os gêneros poéticos (um deles ou um pequeno grupo deles, dependendo dos trabalhos anteriores feitos pela turma, sua faixa etária e repertório), não se pode esperar que o aluno responda num comportamento imediato (interpretar uma imagem ou escrever uma quadra, por exemplo). A compreensão ativamente responsiva de efeito retardado promove resultados diversos em sujeitos diferentes. É preciso fazer uma atividade exploratória inicial com os gêneros poéticos (inserida ou não em uma sequência didática), para diagnosticar os tempos de

\footnotetext{
${ }^{73}$ Cf. p. 41
} 
leitura e escritura pré-existentes em relação ao gênero. Por essa razão, uma abordagem com progressão em espiral (que retorne ao mesmo gênero, apresentando outros elementos ou solicitando outras tarefas) permite recuperar e ampliar esses tempos, uma vez que, ao voltar para o poema ou o gênero, constrói-se o espaço para que a compreensão ativamente responsiva alcance seu término.

\title{
3.4 O poema: uma esfinge? 0 poema diante dos olhos dos alunos
}

Uma das representações do poema, se transformada em imagem, seria a da esfinge. No caso dos gêneros poéticos, o desafio "Decifra-me ou devoro-te" acaba por ser apenas "devoro-te". Assumir a face da esfinge deriva, numa primeira leitura, das formas composicionais e do estilo, pois se a esfinge é um ser paradoxal para a natureza, os enunciados dos gêneros poéticos também o são. Isso em parte resulta das relações estabelecidas no discurso verbal poético:

\begin{abstract}
$\mathrm{Na}$ poesia, como na vida, o discurso verbal é um “cenário” de um evento. A percepção artística competente representa-o de novo, sensivelmente inferindo, das palavras e das formas de sua organização, as interrelações vivas, específicas, do autor com o mundo que ele descreve, e entrando nessas interrelações como um terceiro participante (o papel do ouvinte). Onde a análise lingüística vê apenas palavras e as interrelações de seus fatores abstratos (fonéticos, morfológicos, sintáticos, etc.), a percepção artística viva e a análise sociológica concreta revelam relações entre pessoas, relações meramente refletidas e fixadas no material verbal. O discurso verbal é o esqueleto que só toma forma viva no processo da percepção criativa, conseqüentemente, só no processo da comunicação social viva. (BAKHTIN; VOLOSHINOV, 1926/1976, p. 12)
\end{abstract}

Dessa forma, os leitores de poesia têm de reconstruir cenários, elaborar outros, percorrê-los por fim. Esses gestos, de percepção criativa, permitiriam a relação com a esfinge e não, a percepção superficial de algo que não tem sentido, o desarranjo. Na concepção dos gêneros discursivos, o papel do ouvinte / leitor passa a ser então central para a própria existência do poema. Que seria da esfinge sem alguém para quem ela propusesse seu enigma? Por outro lado, como promover essa aproximação? Quem se apresenta como proficiente para enfrentar os desafios dela?

Os leitores, muitas vezes, têm uma posição bastante coerente a respeito dos gêneros poéticos e enfrentam (em geral não da forma que nós, professores, gostaríamos) os 
enunciados desses gêneros de acordo com essa concepção. Se o professor passou por todas as etapas de elaboração da proposta de ensino do gênero poético, ampliou suas representações a respeito do enunciado com que vai trabalhar, precisa agora encontrar outros leitores de poemas: os seus alunos.

\subsubsection{A autoridade do leitor de poemas}

Quem se considera leitor de poesia?

Outro dia, minha filha de sete anos estava tomando banho e começou a me contar sobre um poema que havia ouvido em um desenho animado. Ela dizia com grandes pausas entre as frases: “O mundo está morrendo... o mundo está morrendo... o mundo morreu!”. Por fim, ela completou: "hump!". "Você não gostou?", perguntei. Rapidamente ela me respondeu, marcando a resposta com os dedos da mão: "Não tem sentido, não tem rima, não tem graça". O que isso significa? A busca das representações sobre o gênero poético. Por quê?

Há muitas representações sobre os gêneros que orientarão condutas e posturas para a lisibilidade dos poemas. Mesmo os alunos que não nomearam esses gêneros poéticos, podem fazê-lo por aproximação no momento em que o professor iniciar o trabalho com a SD sobre esses gêneros. Assim, uma das primeiras ações em sala de aula é descobrir quais representações de poema estão presentes. Trata-se de um trabalho metalinguístico (cada um vai demonstrar qual tipo de vocabulário ligado aos poemas conhece) e metacognitivo (a ação e a forma tipificada que a ela corresponde são indiciadas em estruturas cognitivas) ${ }^{74}$ que não responderá, de forma definitiva, à questão principal, "o que é o poema", mas auxiliará o professor na determinação dos espaços com os quais ele vai trabalhar e nos quais estão seus alunos.

Em “O discurso na vida, o discurso na arte”, Bakhtin e Voloshinov (1926/76) afirmam que a questão do discurso da vida é estar vinculado a uma situação enunciativa específica que não se apresenta no verbal e não pode ser pressuposta ou reconstruída a partir dele. Tomando

\footnotetext{
${ }^{74}$ Sobre metalinguiístico e metacognitivo, cf. TRAVAGLIA, 2003.
} 
como base os mesmos elementos definidores, o discurso da arte não pode deixar algo no não dito, porque não pode depender dessas situações extralinguísticas.

Essa questão poderia ser argumento suficiente para um estudo do poético do ponto de vista formal. O formalismo estabeleceria nessa desvinculação a justificativa para entender cada um dos elementos composicionais como definidores do poema, que não remeteria a nada externo. "Para o método formal, uma obra poética é um material verbal organizado de algum modo particular como forma. Além disso, ele toma o verbal não como um fenômeno sociológico, mas de um ponto de vista linguístico abstrato." (BAKHTIN; VOLOSHINOV, s/d, p. 3) Porém, o papel ativo do leitor e o futuro papel do leitor na função de autor estão fundados no fato de que "o discurso verbal é o esqueleto que só toma forma viva no processo da percepção criativa consequentemente, só no processo da comunicação social viva." (BAKHTIN; VOLOSHINOV, s/d, p. 12). Somente quando se toma como elementos do gênero, quem fala a quem, quando e como, ou seja, o autor e o leitor, tema e estilo nas formas composicionais, é possível discutir a ideia de gênero no ensino.

Mesmo que se entenda que o discurso poético é isolante, a natureza dialógica da linguagem faz com que retornemos aos enunciados concretos; neles, atuam as comunidades interpretativas e cada leitor lê de dentro dessas comunidades. Por essa razão, ao ler um texto literário - no nosso caso, o poema - ele traz uma gama de pressuposições que estão ligadas às atividades literárias, que aquela comunidade específica estabeleceu como válidas ou legitimadas, e às atividades daquela comunidade em si, os sistemas de valores que a sustentam e a definem.

As comunidades interpretativas ligadas ao gênero literário ou ao poético podem estar no horizonte de expectativas do leitor ou não. Se forem alheias a ele, isso não significa que ele não pertença a nenhuma outra, pois a agência, nesse caso, do aluno-leitor ocorre dentro de comunidades menos específicas, não estando necessariamente ligadas às ações desenvolvidas por meio do e no gênero.

As posições circunscritas pela comunidade específica, que a escola legitima (embora nem sempre o professor concorde com ela ou entenda seus pressupostos), a serem ocupadas por esse leitor podem ser constituídas por lugares que ele desconhece ou que não consegue ocupar, uma vez que não traz as chaves interpretativas e o modus operandi requerido para que sua leitura seja autorizada. Essas dificuldades em relação ao gênero literário podem ser explicitadas e trabalhadas dentro da perspectiva discursiva. Principalmente, porque os 
gêneros poéticos como gêneros discursivos ampliam a questão da forma composicional para explicitar um modo de se posicionar socialmente, trazendo em si as representações sociais a ele associadas, que partem da posição que este sujeito-leitor traz para o texto.

Em sala de aula, o discursivo promove o compartilhar das chaves interpretativas entre alunos e professores, por meio da explicitação dos critérios adotados para sua sistematização. Isso permite a negociação desses valores entre a comunidade interpretativa externa e essa comunidade constituída ad hoc durante o trabalho com o texto concreto, o texto colocado em discussão.

Dessa forma, determinadas as representações que os alunos têm do gênero poético (e a que o professor trouxe de antemão), a segunda tarefa seria ampliar essas concepções por meio da explicitação das vozes presentes no poema. Essas vozes podem estar presentes pela escolha lexical, pelas estruturas tipificadas em outros gêneros, pelo tratamento dado ao tema (o uso da primeira pessoa ou da terceira, por exemplo).

Estudar o poema não significa deixar fora da análise os recursos estilísticos provenientes da tradição dessa disciplina tais como os recursos sonoros, lexicais, sintáticos etc. A esses, o professor deve acrescentar, nível a nível linguístico, a questão enunciativa. A estilística da Enunciação teria o papel de resgatar no estudo dos gêneros esse aspecto discursivo, posto de lado nas análises estritamente linguísticas, como foi possível observar nas análises dos poemas dos alunos ${ }^{75}$, presentes na voz que tenta sustentar a autoridade, projetando ethé diversos e esclarecedores quanto ao papel do "tema" (no caso do Prêmio, o lugar onde vivo) no enunciado concreto na atividade proposta.

\subsection{Sabe o nome do poeta? Propostas para a escritura do poema}

A partir da identificação do decoro exigido para os gêneros poéticos, ao se colocar como leitor desse gênero em atitude ativamente responsiva, os alunos são levados à escrita desses gêneros, entendida como uma das formas de agência, permitindo a relação desses alunos com o mundo por meio dos enunciados poéticos. E por que faríamos isso?

\footnotetext{
${ }^{75}$ Passim Capítulo 2
} 
A experiência estética em geral, não somente a verbal, tem função formadora e permite a ampliação dos horizontes expressivos do sujeito. Deslocá-los da leitura para a escrita promove também a perspectiva central do discurso poético que é lidar com o "isolamento" da voz do poeta. De certa forma, é uma maneira mais explícita de se trabalhar com a questão da autoria, uma responsabilização da qual não se pode fugir no enunciado poético. Porque a poesia, como forma de arte verbal, permite a experimentação e uma "liberdade" significativa, mesmo dentro de um sistema já estabelecido como o linguístico. Se a literatura permite essa experimentação, a poesia permite que ela ocorra em grau máximo, rompendo às vezes com a comunicação, ao criar novas formas de entender as estruturas já tradicionais, seja dentro das palavras, das orações ou nos textos, por processos de ressignificações que colocam o autor numa posição adâmica (pelo menos no momento de elaboração, para depois encontrar de novo seus pares).

Roberto Vecchi, em uma palestra sobre Elefante, de Francisco Alvim, afirmou que os poetas escrevem em uma língua morta. É possível concordar com o crítico e professor de literatura, assumindo que o isolamento do discurso poético, ao modificar as bases para a compreensão, coloca o leitor fora do código compartilhado para depois atrai-lo para dentro do enunciado poético. Como os latinistas e outros estudiosos de línguas mortas fariam, para compreender os textos poéticos, é imprescindível compreender quais são os elementos discursivos, de qual perspectiva aquela enunciação é feita, como é possível atribuir significados aos elementos das formas composicionais. Essa reconstrução tende a encontrar formas de se apresentar no momento da escritura do aluno. Desde a descoberta de uma figura de linguagem, um jogo de palavras até o diálogo com outros textos e vozes, feitos nesse momento de forma mais programática, embora nem sempre tão conscientemente.

Para a elaboração de uma proposta de escritura nos gêneros poéticos, outro fator a ser levado em conta é aquele apontado pelos autores russos ao conceituar o poder discursivo desses enunciados: "Poderíamos dizer que uma obra poética é um poderoso condensador de avaliações sociais não articuladas - cada palavra está saturada delas. São essas avaliações sociais que organizam a forma como sua expressão direta." (BAKHTIN, VOLOSHINOV, s/d, p. 11) Essa é uma das oportunidades de agência que o aluno pode assumir ao escrever um poema, ao compor e ao buscar em si a compreensão do que o circunda, ao mesmo tempo em que explicita seus valores, suas concepções, em um gênero marcado pela fala com isolamento, isto é, sem a influência de outros aspectos limitadores, como no caso da 
reportagem ou do relatório em que os suportes e os empregadores e financiadores podem moldar as formas de expressão.

\subsubsection{Uma proposta, muitas propostas, nenhuma delas}

A proposta para o tratamento a ser dado aos enunciados poéticos como gêneros discursivos no espaço escolar permeia todo esse capítulo, porém, para tratar da escrita desses gêneros, retomou-se outra proposta com o intuito de justapor àquela do Prêmio e verificar quais as diferenças significativas e quais as coincidências de procedimentos.

Os critérios para a escolha foram apenas as diferenças no momento de circulação, ou seja, a proposta teria de ser aplicada na escola em tempos didáticos regulares e não, num momento de exceção. No entanto, o suporte metodológico e teórico para ambas era o mesmo, por essa razão, foram escolhidas as sequências didáticas do caderno de atividades, versão aluno, da coleção "Expression écrite - lire pour écrire, écrire pour lire: une méthode pour maîtriser l'écrit" (Expressão escrita - ler para escrever, escrever para ler: um método para ensinar a escrita), de Schneuwly e Revaz (e colaboradores).

Nos cadernos CM1 e CM2, encontram-se duas unidades para o trabalho com o poema. Ambas intituladas "Jouer avec la langue" (Brincar com a língua). Essa denominação corresponde a ações dentro de um dos domínios sociais de comunicação uma vez que as demais unidades são denominadas como "échanger - l'invitation" (trocar - o convite); "convaincre - Le pour e Le contre" (convencer - os prós e os contra); "raconter - Le conte" (narrar - o conto); "dire comment faire - La notice de fabrication" (dizer como se faz instruções de montagem); "décrire - Le portrait" (descrever - o retrato); "expliquer - Le fonctionnement d'um objet" (explicar - o funcionamento de um objeto). Assim, para os autores, o domínio em que aparece o poema é o do lúdico.

A primeira sequência de atividades no caderno CM1, se referia a "jouer avec la langue - des poèmes avec des rimes" (brincar com a língua - poemas com rimas). As atividades dessa unidade estão relacionadas à forma composicional como ferramentas para a escrita posterior. Trata-se de uma sensibilização para a escrita tendo como parâmetros: uso da rima; do metro e da estrutura paralelística das estrofes. Para tanto, havia três poemas com essas 
formas composicionais (além da disposição gráfica em versos). A segunda sequência, no caderno CM2, se refere a "jouer avec la langue - l'ecriture d'un poème" (brincar com a língua - a escritura de um poema). As atividades, nesse caso, foram ampliadas. Partia-se da verificação de domínio do vocabulário referente às formas composicionais (rimas, estrofes, metro) em quatro poemas com elementos composicionais comuns (eram rimados, apresentavam metro e estrofes regulares) em configurações bem diversas, para então propor a escritura. As formas composicionais e alguns traços das formas arquitetônicas estão presentes, indicando que "brincar com a língua" é apenas um dos domínios dos gêneros poéticos. Haverá outros?

Aparentemente o poema estaria cercado pela idéia da disposição em versos, pelo lúdico e pelas formas composicionais, porém, no Guia Pedagógico, de Schneuwly e Sandon (1996), destinado ao CE2, o embate apontado neste capítulo entre a multiplicidade dos gêneros poéticos e a singularização do ensino desses gêneros é dirimido pelas orientações dadas ao professor para que conduzisse a sequência didática: poemas com "se". As primeiras se referiam ao fato de que se estava trabalhando com os "aspectos formais da poesia" (1996, p. 32)

\begin{abstract}
A literatura moderna disponível aos alunos oferece uma enorme diversidade de formas poéticas entre as quais será inútil procurar gêneros muito estáveis. Assim nossa escolha se deu por uma forma repetitiva em "se" e pela organização de atividades sobre ela e outras que ela permite: a invenção de um mundo graças às palavras. (....)

Trata-se, portanto, de brincar com a língua, mas é um jogo em que já se pode perceber a potência da criação de mundos. (SCHNEUWLY; SANDON, 1996, p. $33)^{76}$ (tradução nossa)
\end{abstract}

Como se observa, questões ligadas às formas arquitetônicas surgiam ao lado das formas composicionais, e da mesma maneira que Jolibert (1994), citada para ilustrar o modo de se desenvolver atividades diversificadas na $\mathrm{SD}^{77}$, os autores buscaram os gêneros que se apresentavam como estáveis pela presença de alguns elementos composicionais para estabelecer um modo de trabalho com os gêneros poéticos.

\footnotetext{
${ }^{76}$ La litterature moderne accessible aux enfants offre une très grande diversité de formes poétiques dans laquelle il serait vain de vouloir chercher des genres bien établis. Nous avons pris le parti de choisir une forme répétitive em "si" et d'organizer lês activités autour d'elle e de ce qu'elle permet: l'invention d'um monde grâce aux mots. (....)

Il s'agit donc de jouer avec la langue, mais c'est um jeu on va déjá pouvoir percevoir la puissance de création de mondes.

${ }^{77}$ A indicação da autora aparecia na nota de rodapé 70 , à página 11 no caderno CM2.
} 
Estava, nessa busca de estabilidade, o conflito central entre uma visão proveniente da tradição dos estudos literários e a busca por novas concepções. A saída apontada pelos autores parecia retomar, por um lado, os caminhos percorridos na esfera literária - a passagem de uma concepção tripartida de gênero para o predomínio lírico como sinônimo de gênero poético a partir de certa estética romântica; e, por outro, uma concepção mais estrutural do texto poético como sistematizado no quadro (p. 36) do caderno CM2, em que os autores indicam os elementos a serem utilizados como ferramentas para a reescrita:

1. Um poema tem título, estrofes (um conjunto de dois ou mais versos), espaços entre as estrofes, nome do autor;

2. Em geral, um poema obedece a algumas regras:

- é comum encontrar no fim dos versos, palavras que terminam pelo mesmo som: são as rimas. (....)

- um verso é composto por muitas sílabas $(4,6,8,12)$. No poema, os versos têm em geral o mesmo número de sílabas quando lidos. (....)

3. Um poema pode descrever qualquer coisa (uma paisagem, um objeto...) (....)

Pode ainda exprimir sentimentos, como a tristeza do poeta. (....)

4. Pode-se escrever um poema pelo prazer de brincar com os sons e as palavras.

Surge, nesse ponto, a importância de se propor como fazem os autores, o "Brincar com a língua", como um domínio, que se instaura nesse contexto de escolhas para se trabalhar com o poema como uma saída para além das questões formais, porque a língua não pode ser tomada (em nenhum de seus níveis) como estruturas sem vinculação às variações sociais. A concepção de língua nesse caso absorve o contexto social, sendo constituída por ele e constituindo as representações que interferem nas formações discursivas presentes na sociedade. "Brincar com a língua" é também uma forma de entender que existe uma concepção mais abrangente de língua que precisa sair das linhas de pesquisa de estudos discursivos e entrar para a graduação em cursos de bacharelado e de licenciatura.

Na tensão entre essas formas de conceber a língua e o ensino de língua portuguesa, procurou-se ainda mais uma proposta sempre em diálogo com a proposta de Schnewuly, Dolz; e no caso do poema com Schneuwly, Revaz e Sandon, trata-se da coleção didática de Português das Escolas Associadas (2009). Um projeto cujo instrumental central é a sequência didática e cujos conceitos norteadores são a progressão em espiral constituído pela opção por modelos sociais em uso; pela diversidade textual e pelos fatos da língua, como consta no Caderno de Orientação ao Professor (COP) da mesma coleção.

Nos volumes do $6^{\circ}$ ao $9^{\circ}$ anos, o poema aparece em vários momentos, com diferentes diálogos com outros gêneros e com diversas formas composicionais e arquitetônicas, sempre no capítulo 2 da unidade 2 . No $6^{\circ}$ ano, os gêneros poéticos surgem com o título: "Poesia: 
mais que um jogo de palavras", em que a exploração do aspecto lúdico, o jogo, assume uma função discursiva. Seguindo a estrutura das SDs, nesses capítulos, há um espaço para o reconhecimento das formas composicionais e do papel da leitura em voz alta para alguns dos poemas, depois as questões e o trabalho da leitura passam para o processo de constituição dos sentidos. No $7^{\circ}$ ano, pode-se observar que a progressão em espiral se apresenta, no capítulo, intitulado "Poesia: uma janela para o mundo", em que há a retomada das características do poema, incluindo a noção da "forma em rede" ao lado das tradicionalmente reconhecidas como rima e figuras de som. Se no $7^{\circ}$ ano, a poesia foi apresentada e discutida como forma de apropriação do mundo, no $8^{\circ}$, há uma volta para as questões que envolvem os gêneros poéticos como forma especial de comunicação, de estar e agir nesse mundo. $\mathrm{O}$ trabalho com o ritmo se intensifica e as relações entre ritmo e tema são também verticalizadas. Por fim, no $9^{\circ}$ ano, há uma ampliação das concepções de gênero poético com a mescla de códigos, com o título, "Poesia: composição verbal e visual". Trata-se de uma forma de ampliar os conceitos e promover novas representações do poema além do cânone mais tradicional.

Retomando a questão de como indicar o agrupamento dos gêneros poéticos, vê-se a necessidade de uma discussão maior que foi, em parte, empreendida pelas autoras da coleção didática das Escolas Associadas, pois, ao apresentarem as orientações para os professores, indicam que a opção delas por "poesia" dialoga (em confronto) diretamente com outras propostas como a de Sérgio Roberto Costa, em Dicionário de gêneros textuais (2008). O autor sugere para o agrupamento de gêneros o "avaliar" e o "poetar", como possível ao lado de "narrar", "relatar", “argumentar", “expor”, "prescrever / descrever ações”. Para elas, o neologismo não daria conta de todas as questões que circundam os gêneros poéticos, daí o retorno a um termo mais abrangente que envolve enunciado e efeitos decorrentes: "Nesta coleção, entre o neologismo "poetar" e o termo "poesia" - que remete ao efeito resultante da leitura dos textos poéticos -, optamos por este último, para designar o agrupamento de gêneros que compreende os diversos tipos de poemas." (2009, p. 7)

O que se observa se se colocar lado a lado as coleções e o Kit é a questão da progressão em espiral. No material do Prêmio, as atividades são desenvolvidas de forma condensada, em razão das atividades ocuparem um tempo, ao mesmo tempo, dentro e fora do planejamento, ou seja, é necessária uma perspectiva que não se esgote nesses momentos, ou na sequência. As coleções apresentadas pressupõem retomadas num tempo pedagógico mais amplo embora compartilhem pressupostos teóricos e algumas representações dos gêneros poéticos. 


\subsubsection{Então esse é o problema?}

Apontar a insuficiência das propostas parece ser uma tarefa fácil. Há sempre critérios ou pressupostos que podem validar ou não certas abordagens. No entanto, como o que se busca é a compreensão de como as propostas podem modificar a representação dos gêneros poéticos, ampliando as concepções e o modo de se relacionar com eles, optou-se pela manutenção de certos traços reposicionados dentro do universo da esfera literária. Não se trata mais de trazer algo inédito, mas de ressignificar alguns percursos.

Há certos aspectos presentes nessas propostas que permanecem. O primeiro é a estabilidade de certos gêneros poéticos em torno das formas composicionais. Elementos das formas composicionais como rima e metro podem ser apresentados aos alunos de modo a fornecer um modelo com os quais eles possam trabalhar e entender a dinâmica das formas arquitetônicas e composicionais. Esse diálogo no poema pode aparecer em gêneros primários ou em gêneros secundários com forte ligação com os primários, com circulação na modalidade escrita. Trata-se de uma tentativa de recuperar os elementos lúdicos e ao mesmo tempo cinestésicos, que são constituintes nesses gêneros.

Como apresentado na discussão sobre a leitura, aprender a escrever o enunciado poético deve ser dosado com a progressão em espiral. Poucos elementos devem ser trabalhados e esses devem preencher a atenção daqueles que se iniciam na expressão escrita. Mesmo leitores mais proficientes podem ter dificuldades em elaborar um poema com todos os elementos discursivos e composicionais atuando juntos. Na progressão em espiral, o aluno experimenta certas formas e quando volta ao gênero poético, verifica o que sabe para avançar mais um ou dois elementos. Embora o número de elementos a serem trabalhados possa variar de acordo com a idade do aluno, é importante não se esquecer da compreensão ativamente responsiva de efeito retardado. Assim nem sempre os alunos (mesmo que tenham mais experiência) responderão a todos os elementos apresentados de forma similar ou num mesmo ritmo. Compreender, por exemplo, como cada grupo é afetado pelas formas arquitetônicas, pode ser um ponto de partida produtivo. Dessa forma, Goldstein formula a questão do trabalho da progressão em espiral com os poemas: 
Acreditamos que esse processo "em espiral" solidifica a experiência dos leitores - e produtores - de poesia, complementando pouco a pouco o elenco de recursos expressivos presentes no texto poético, de modo a levar os alunos a reconhecê-los e empregá-los cada vez mais e melhor. Como resultado paralelo, mas nada desprezível, são apresentadas várias noções acerca de como se constroem os efeitos de sentido, incluindo tanto aspectos que funcionam na linguagem em geral, poética ou não, (como os morfossintáticos, os semânticos e os de construção de figuras de linguagem) quanto aqueles mais específicos do poema (como a métrica, o ritmo, a organização particular), sem perder de vista a conjunção entre a linguagem verbal e a não verbal. (2006, p. 377)

O estabelecimento de um repertório quanto a esses elementos formais e discursivos decorrente dessas atividades de progressão em espiral pode conferir maior proficiência ao aluno para que arrisque e se sinta capaz.

Assim, sempre que o professor for trabalhar com os gêneros poéticos, deve atenuar e chegar até a eliminar a etiquetação de todos esses gêneros somente como poema. Essa denominação carrega uma univocalidade que pode levar novamente a tornar as formas composicionais mais relevantes do que o diálogo entre elas e as formas arquitetônicas. Além disso, etiquetar a todos como poemas é também subentender que os gêneros prosaicos são múltiplos enquanto o poético se resume a texto versificado. Na classificação de Schneuwly e Dolz (2006); e Barbosa (2001), há vários gêneros designados na esfera literária: narrativas de mistério; narrativas de ficção científica, conto, conto maravilhoso, conto de fadas etc. Com os poemas, pode ser feito o mesmo embora as categorias (pelo menos algumas em enunciados poéticos contemporâneos) ainda estejam no compasso de espera para uma nova classificação. Qualquer proposta vai apresentar lacunas porque não se pode trabalhar a totalidade de conhecimentos quando eles são produzidos contemporaneamente às propostas. Por exemplo: Manuel Bandeira escreveu sonetos. Isso é mais fácil de identificar, porém ele tem poemas em versos livres. Essa pode ser uma classificação? Provavelmente, sim. Pode apresentar certa incompletude, mas é uma primeira aproximação que os estudiosos de literatura poderão suprir ao lado dos estudiosos dos gêneros.

Para que a descrição fique mais completa, podem-se cruzar dois ou mais tipos de traços definidores, por exemplo, elementos da forma composicional e o tempo em que foi escrito, como poema em versos livres do século XX. Quanto mais traços forem incorporados nessas classificações, mais fácil será constatar que os poemas são diversos e que agrupá-los todos juntos é uma forma de apagá-los como gêneros. Não se trata, porém, de trocar uma forma insuficiente ainda para classificar por outra igualmente lacunar. $\mathrm{O}$ que se quer afirmar é a multiplicidade que ultrapassa o cânone anterior. 
Em Adam (1985), há uma intensa exposição sobre estruturas do tipo textual poético: a disposição na página; o poema como gramática; os níveis linguísticos e o poema; a articulação das figuras de linguagem etc. Ao observar como elas se apresentam e se relacionam, percebe-se o uso do macrotraço "referente interno" para determinar e situar elementos que estão em questão no enunciado poético. Embora Adam tenha assumido, em trabalhos recentes, outras formas de organizar os tipos textuais em que o poético não está incluído, tomar o texto poético como uma unidade (o que ele fez nesse livro de 1985) e, dentro desse evento criado nas estrofes, verificar as formas composicionais remete a uma outra abordagem a ser incorporada nas propostas de foco discursivo: a dos estudos estilísticos.

O cruzamento da estilística da língua com a estilística literária, tendo como ponto de partida, o nível enunciativo parece contemplar vários dos elementos apontados por Bakhtin e Voloshinov (1926/1976), uma vez que permitem a recuperação do trabalho com a linguagem (não desfazendo as fronteiras entre o professor de língua e literatura); remetem ao diálogo das formas com os temas (instaurando nova representação para cada um dos gêneros poéticos, uma estilística do gênero); e identificam grupos temáticos ou composicionais para o trabalho da leitura e da escrita sempre partindo da noção de que o espaço do enunciado poético tem regras e peculiaridades que não coincidem de modo completo com o mundo exterior, mas com ele mantém relações de pertença e reformulação, que também podem ser entendidos como tradição e inovação.

Incorporar a abordagem dos estudos estilísticos retoma a concepção de gênero discursivo e permite ao professor de Língua encontrar um espaço mais favorável em que ele não renuncie à especificidade de sua formação, ao mesmo tempo em que se abra para assumir seu papel de leitor e também de autor. Como pode o professor pedir uma atividade para seus alunos, se ele mesmo nunca a experimentou? Esses estudos serão possíveis no momento em que o professor compreender as atividades que propõe não somente do ponto de vista de quem propõe, mas de quem as executa também. Entender os gêneros poéticos como um objeto de ensino que ultrapassa a fruição, sem jamais perdê-la de vista.

Um desses casos ocorreu na minha sala de $5^{\circ}$ semestre do curso de Letras - Tradutor e Intérprete (Unibero) ${ }^{78}$. A proposta, “A Infância em redondilhas", tinha como objetivo

\footnotetext{
${ }^{78}$ Esses alunos estão no início do $3^{\circ}$ ano de curso e têm um perfil bastante variado de idade. Para alguns, é a primeira faculdade; para outros, a segunda.
} 
sensibilizá-los quanto a ritmos e metros, figuras de som e construção, como parte do conteúdo da disciplina Língua Portuguesa - Estilística, sem que para isso fosse necessário recorrer somente a uma exposição teórica, ou seja, que eles percebessem as formas composicionais em tensão com as formas arquitetônicas, tal como nas propostas de Schneuwly e Revaz (2002; 1994), Schneuwly e Sandon (2002) e Goldstein (2009).

A explicitação das etapas da SD nos enunciados concretos, ou seja, na produção dos alunos, também se mostrou como instrumento importante para a adesão do aluno e para a elaboração de outras formas de se entender os tempos de escrita. Compreendendo essa situação, ao longo desses anos, a comissão que organiza o Prêmio (atual Olimpíada de Língua Portuguesa) tem produzido um material de apoio que indica as respostas possíveis dos professores para as atividades com cada um dos gêneros abordados no Prêmio. Nos almanaques do Programa Escrevendo o Futuro, intitulados "Na ponta do lápis", os professores apresentam suas experiências, trocam ideias; e podem ler sobre novas estratégias, novas formas de compreender como se dá o estudo dos textos pelos gêneros. No caderno, $\mathrm{n}^{\circ} 3$ (março/abril, 2006), "poema espalhado, prazer dobrado", há um relato de experiência da seção "De olho na prática" em que se apresentam todas as etapas pelas quais passou o aluno para que chegasse à sua obra-prima. Trata-se de "Com quantos textos se faz um texto de qualidade?" que permite desde o título a compreensão dos percursos necessários para se chegar a desenvolver no aluno a noção de que o gênero poético como qualquer outro necessita de trabalho e da assunção da autoria que se alcança pela intervenção consciente nos enunciados. No caso da atividade na minha disciplina, após as duas aulas, a elaboração do poema continuou via mensagens eletrônicas. Assim, a indicação dessas etapas se deu pelo uso da ferramenta "controlar alterações" do processador de textos. Cada aluno tinha, no arquivo do poema, a "história" de sua escrita, e, dessa maneira, pode conversar comigo a respeito de seu percurso ao fim do processo.

Embora os alunos tivessem mostrado resistência inicialmente, quando se estabeleceu que os poemas seriam elaborados em várias etapas acompanhados de conversas entre eles e eu, a oposição diminuiu e, ao fim, muitos deles antes que eu solicitasse promoveram a circulação dos poemas em outros espaços, como o familiar (uma das alunas mostrou para o pai, que mostrou para a tia e assim por diante) e o do trabalho (outra aluna mostrou, antes da versão final, para o chefe e, então, eles discutiram como conseguir a redondilha em certos versos). Como aconteceu no Prêmio, a recepção dos poemas por outros interlocutores permitiu que os alunos se sentissem mais seguros e insistissem nas redondilhas. Houve a 
assunção da posição de autor, mesmo que o texto ainda estivesse, em alguns casos, demonstrando alguma insuficiência se analisados a partir da proposta.

Dessa maneira, sem que eu percebesse, outro elemento importante surgiu dessa preocupação com o repertório de formas composicionais que, naquele momento, tomei como centro das atividades de um bimestre ${ }^{79}$. Esse elemento foi aparecendo aos poucos na fala de outros professores que vieram me perguntar: "Você pediu para que os alunos escrevessem poemas?" Quando eu começava a responder, eles diziam: "Não sei se seria capaz de fazer..." Essa fala tão sincera dos professores indicou como era importante falar sobre esse fazer, declarar sua potência, uma forma avaliativa da atividade e do próprio "poetar" que ancorava a produção de poemas como uma habilidade desenvolvida e não somente a um episódio esparso. Era o elemento que preenchia uma lacuna nas propostas (embora já estivesse presente na proposta de Jolibert, 1994a): estimulava os alunos para além dos limites da atividade, e, no caso da faculdade, os professores também.

Uma das últimas etapas da SD é a revisão do texto, cujo guia, a grade de avaliação, permite verificar se o poema se adequa à proposta e se os elementos característicos daquele gênero estão contemplados. Dessa etapa, saem os parâmetros para uma nova escritura que levarão à obra-prima tal como concebe Jolibert ${ }^{80}$. Essa etapa, porém, se mostrou insuficiente para os alunos do $5^{\circ}$ semestre, eles sentiam a necessidade de falar sobre o que haviam feito e como, indicar as dificuldades, expor o resultado. Por essa razão, quando foram solicitados pela coordenação para participarem do Sarau de fim de ano, evento em que os alunos podem apresentar músicas, poemas, trechos de narrativas, citações, coreografias de balé e afins, oito alunos decidiram apresentar o poema que haviam escrito.

A atividade, que podia ser considerada apenas metalinguística, implica novos caminhos como desenvolvimento de outras representações em relação ao gênero (os alunos ainda reconhecem que escrever poema em métrica regular é trabalhoso, mas aceitam-no como espaço legítimo da expressão da infância e talvez de outros temas), e o estabelecimento de uma posição autoral (mesmo que, em seus primeiros momentos, em alguns casos), pela clareza de propósitos e domínio da unidade textual.

\footnotetext{
${ }^{79}$ A proposta do poema se alinhava a outra da adaptação de uma cena de Romeu e Julieta para romance juvenil. ${ }^{80}$ Cf. p. 30.
} 
A proposta ${ }^{81}$, claramente calcada na estrutura das atividades da SD (como aparecia no Prêmio e nas demais propostas aqui analisadas) possibilitou que a atitude responsiva dos alunos, não somente em relação ao produto, o poema, mas também em relação às atividades, deslocasse o meu lugar na sala de aula, levando a novas direções dentro da "provocação" inicial. Provavelmente, em algumas das escolas, algo semelhante ocorreu. Decorre disso, a importância dos relatos ${ }^{82}$ - não somente do processo em si (as várias versões), como também um relato, como protocolo de escrita, em que essas impressões possam ser documentadas e analisadas ao lado do poema como produto dessa atividade. No meu caso, embora haja alguns e-mails que trazem a avaliação do processo de escrita e do enunciado resultante ("foi muito bom poder falar de novo da minha infância e do que aconteceu comigo e com minha irmã"), considero-os ainda pouco significativos por ter a certeza de que podem ser instrumentos relevantes para o professor e para o aluno observarem suas posições dentro do processo de escrita de um gênero da esfera literária, como o poema em redondilha, no entanto, rendo-me ao fato de que eles não queriam contar para mim nem dividir essas experiências comigo. Queriam contá-las a outros, instituir uma audiência que estivesse além da nota a ser atribuída no fim do semestre. Queriam recuperar a fruição, o "brincar com a língua", brincadeira que eles estabeleceram desde o princípio como sendo de dois participantes ou mais, numa tensão suave (para eles) e mais intensa (para mim, pois a atividade saiu fora de meu controle avaliador).

A atitude dos alunos derivada desse trabalho também pode ser alcançada com outros gêneros, contudo o grau de exposição pode ser menor, em parte, porque a representação de alguns gêneros nem sempre é problemática. Muitos alunos não reclamaram da adaptação proposta a eles, alegando que narrativas são mais fáceis de fazer. Por considerar ambos os gêneros da esfera literária suficientemente complexos, percebo a representação colocada entre o aluno e a realidade da escrita, moldando suas estratégias e aproximações.

\footnotetext{
${ }^{81}$ Anexo 3

${ }^{82}$ Hoje os relatos foram sistematizados dentro da dinâmica das etapas de avaliação e escolha dos poemas finalistas.
} 
Considerações finais

Da Paratopia à utopia? 
Por causa da redondilha

Quase não vejo a família

(....)

$(\text { VÁRIOS, 2009) })^{83}$

Retorno à primeira pessoa, de forma mais explícita, nas considerações finais para poder retomar minha posição de professora uma vez que a posição de pesquisadora foi mantida nas páginas anteriores. Muitas vezes, ao ler os relatos de trabalhos com os gêneros não posso me furtar à emoção que sinto ao ver os alunos lendo e produzindo em processo de formação pessoal e cidadã.

Essa emoção que deveria ter sido exilada das pesquisas indica que ainda consigo fazer a ponte entre as preocupações acadêmicas e as aflições de sala de aula. Propor abordagens para o trabalho com o texto poético refaz as ligações entre as pontas soltas da minha formação. Ao mesmo tempo que, num gesto machadiano, cutuca-me com uma questão: seria utópico? Qual o professor capaz de realizar essa abordagem em sequência didática? Qual seria o professor proficiente para propor classificações que não seriam definitivas, mas que, de qualquer forma, formariam o repertório do aluno? Quem estaria confortável para assumir essa posição?

Acredito que esse professor ainda não exista. Ele está em processo. Uma formação que começou ou que começa quando ele se envolve com outras abordagens, procura outros métodos ou por necessidade própria ou por políticas instituicionais (novos projetos pedagógicos; novas linhas teóricas adotadas etc.). Acredito também que esse professor está a cavalo entre representações, lutando consigo mesmo no diálogo intenso das vozes presentes nas formações discursivas que ele traz.

Como nas sequências didáticas, esse professor apreende certos conceitos e consegue colocá-los em prática. Alguns apenas operacionalmente; outros de forma plena transformando conhecimento e ação numa amálgama. Quem pode avaliá-lo? Muitas vezes ele

\footnotetext{
${ }^{83}$ Versos iniciais da criação coletiva dos alunos do $5^{\circ}$ semestre de Letras - Tradutor e Intérprete, do Unibero, que começou na troca de e-mails e foi encerrada na forma de improviso na lousa, na aula de encerramento do semestre, uma espécie de avaliação das atividades desenvolvidas no $2^{\circ}$ bimestre da disciplina.
} 
está sozinho e, entre os termos de linguagens de especificidade, se sente estrangeiro. Está mais próximo do aluno não pela empatia gerada pela consciência do percurso que o segundo tem de trilhar, mas pela simpatia: ambos estão embrenhados no processo de tal forma que não conseguem enxergar as margens.

Então, é possível o "pneumotórax”? A pergunta não é ingênua nem pretende se afastar do real (nem do "tango argentino"). Apenas tenta indicar ao outro que existem muitas possibilidades e que é possível tentar até mesmo as extremas.

Abordar o gênero poético como discursivo, como vimos, desloca (ou seria mais adequado dizer, empurra) o professor para uma agência via o gênero que talvez ele nunca tenha experimentado e que deverá propor a seus alunos. Ele se representa como potente para essa tarefa? No caso da professora de Santo Anastácio, ela transformou essa dúvida em formação simultânea, ela e os alunos estavam aprendendo. Essa situação promoveu novas representações e certezas nesse professor, estimulou os alunos também. ${ }^{84}$

Abordar o gênero poético como discursivo significa se comprometer com um trabalho de ressignificação dos elementos linguísticos, em formas composicionais situadas historicamente. Qual curso o preparou para isso? O bacharelado ou a licenciatura possivelmente não. Assim o professor entra novamente no circuito docente-discente-docente. Sem sair de seu lugar, ele modifica a configuração de seu espaço.

Abordar o gênero poético como discursivo se apresenta como um modo de investir na formação continuada do professor, pois exige que existam duas posições na prática docente: professor e pesquisador. Pensando dessa forma, talvez tenhamos uma resposta para a sempre preocupante exigência do professor por materiais à moda de receita. Nesse cenário, as propostas de trabalho com o gênero poético devem também ser abordagens que formem o professor como pesquisador. Atribuam a ele potência para abordar os enunciados concretos além da posição de recebedor de teorias. Somos capazes de fazer isso? Ele é capaz de fazer isso sozinho? Acredito que não. O trabalho com o gênero necessita do diálogo constante que deve ser feito na escola e precisa ultrapassar esses limites, desse fato decorre a importância do Prêmio, cujos limites são nacionais e permitem, mesmo que somente aos finalistas, o encontro com outros professores e alunos em uma reunião de excelências e expectativas.

\footnotetext{
${ }^{84}$ Cf. 94, em que há o relato da professora e suas estratégias para envolver os alunos com a atividade do Prêmio.
} 
Uma reunião cuja situação hierárquica semelhante promove uma abertura maior à experimentação e ao outro.

Além do material escrito que circula pela escola, outras formas possíveis para que essa troca aconteça é a internet, nos chats, nos fóruns, nos portais em que a discussão dos gêneros se faça presente e permita a troca entre professores. Um deles é o próprio site da Comunidade Escrevendo o Futuro, ligado à Olimpíada de Língua Portuguesa. Há outros igualmente abertos a esses debates, como o www.educarede.org.br (sobre a educação nos meios digitais); os sites das secretarias de educação; ou ainda de organizações nãogovernamentais que tem projetos de leitura e escrita (www.leiabrasil.org.br).

A noção central de gênero está no fato de ser uma forma de agir socialmente, percebida socialmente. Estamos dispostos como pesquisadores a abrir mão de certa parte dessa produção de conhecimento? Saberemos dizer quanto haverá de espaço para que o professor circule?

As respostas estão na maneira como os teóricos entendem o trabalho com o gênero. Não é possível de saída (e todos eles parecem indicar) que a realização total da proposta parta da academia ou de estudos desenvolvidos longe da sala de aula como ação. Quanto confiamos no professor que está nas oficinas ou nos cursos de especialização, aperfeiçoamento e afins?

Talvez uma das tarefas seja ensiná-los a perguntar e duvidar de nós (como duvido das minhas próprias propostas a serem implementadas em sala de aula muitas e muitas vezes). Não de forma inconsequente, como Narciso simplesmente pela negação do outro. Mas auxiliando-os a dizer: acho que já sabia disso de outra forma.... Será que dá certo? Por que não deu certo quando tentei? Será que é a mesma coisa que estou pensando?

Nos dias de hoje, a representação do professor envolve uma certa falta de tonicidade. A flacidez das convicções diante de constructos teóricos leva-o a lugares muito solitários tornando-o dependente de aprovações de ordens diversas como a dos pais. Obter a aprovação de atores fora da esfera escolar também se apresenta como importante, mas sua influência calcada em percepções parciais pode ser equivocada. Transformar práticas dos alunos, como se observou no Prêmio, é simultaneamente agir nas práticas imediatas e nessas outras esferas, criando um diálogo com pais e a comunidade. 
Nessa perspectiva, o professor pode aceitar ritmos diversos de aprendizagem; "fracassos", ou seja, não desenvolvimento das habilidades e competências listadas no planejamento; mudanças na direção do que foi planejado, a aceitação de um gerenciamento conjunto de atividades. Tudo isso ocorre, porque trabalhar com os gêneros poéticos desperta nos alunos questões que vão além da percepção cognitiva imediata. Como assinalado anteriormente, os alunos nem sempre consideram o texto poético, a sua frente, legítimo. É preciso descobrir quais gêneros responderiam às expectativas deles e encontrariam na sala de aula aceitação imediata e um trabalho menos conflituoso. Da mesma forma, em outros momentos, quais seriam os textos poéticos a desafiar os alunos a ocuparem novas posições? Como superar a resistência? No Prêmio, uma certa apatia foi dirimida com conhecimento, informações transformadas em ações significativas. Nesse caso (a escola de Bariri) ${ }^{85}$, é o reconhecimento da voz do poeta Patativa do Assaré - a representação que ele instaura entre os alunos, carregada de autoridade, porque é autêntica.

As experiências autênticas parecem ser a tônica dos estudos dos gêneros, pois ainda que exista a transposição didática no ambiente escolar, a postura de leitura do professor deve se apresentar dessa maneira. Uma das respostas para que isso ocorra é a leitura do poema que o professor acha relevante e uma das formas de se conseguir essa postura é conhecendo seus próprios gostos, ampliando os limites dessa maneira de apreciar os gêneros poéticos. Afinal, a autenticidade desses gêneros pode acontecer no espaço escolar, uma vez que esse é o espaço preferencial (muitas vezes, o único) para que o aluno encontre alguns dos gêneros poéticos.

Os gêneros poéticos, no entanto, incomodam no momento de sua leitura e produção. Além das questões imediatas e constitutivas da escrita de poemas (ato solitário; exposição de modos de ver e existir no mundo; expertise em formas composicionais), muitas vezes, os poemas trazem à tona questões com as quais o aluno não quer lidar. O professor está preparado para entendê-las? Para lidar com elas sem cair num discurso repressivo ou moralizante?

No Prêmio, as produções dos alunos indicam que insistir em atividades com os poemas, de forma plural, é uma necessidade e procurar percursos que façam sentido para alunos e professores, uma saída. Como se observou, nos poemas, essa conjunção de caminhos é a que mais claramente apontou para a ocupação do lugar de autor de poemas. Principalmente, porque considero esse lugar como o grande desafio. Quem vai aceitá-lo? Há

\footnotetext{
${ }^{85}$ Cf. p. 108.
} 
muitos anos quando comecei a trabalhar com o ensino dos gêneros poéticos, fazia uma pergunta aos professores nos cursos de capacitação: “Quem tem medo do poema?" Hoje ainda me faço essa mesma pergunta e, um pouco sem graça, confesso que, neste semestre, ainda não fiz meu poema em redondilhas para compartilhar com os alunos.

Se os alunos do Prêmio rimavam, e rimavam ressemantizando os lugares, e seus professores, em diferentes contextos, conseguiram incentivá-los e buscar melhores resultados dos que aqueles encontrados na produção inicial, especialmente aqueles que se mostraram propensos a encontrar novos lugares para eles também como mostram os relatos das professoras de Santo Anastácio e Bariri; e um pouco mais timidamente o de Nova Conquista; e, se os meus alunos traziam a infância em sete sílabas métricas, agora é a minha vez, pois insisto que talvez seja esse movimento que ainda nos falte: buscar uma metodologia dinâmica e sempre tensa do diálogo, cujo jogo de forças nos levará além das paredes da sala de aula, ao reconhecer que as formas composicionais não bastam - é preciso ter as peças e as regras, mas isso somente tampouco basta -; é preciso querer jogar. Dessa maneira, por essa oportunidade singular por que aqueles alunos de várias cidades de São Paulo passaram a caminho da autoria, do papel de sujeito nos gêneros poéticos, alguns percursos se apresentam. No estudo dos gêneros poéticos, como discursivos, vejo a possibilidade de promover o trânsito da paratopia, hoje o lugar da poesia na escola, em direção à utopia, busca de não lugares que possam efetivamente se tornar lugares para todos nós e assim convido: “vamos brincar de poesia?" ${ }^{86}$ ?

\footnotetext{
${ }^{86}$ Verso final do poema "Convite", de José Paulo Paes: Poesia/ é brincar com palavras / como se brinca/ com bola, papagaio, pião.// Só que/ bola, papagaio, pião/de tanto brincar/se gastam//As palavras não/quanto mais se brinca/com elas/mais novas ficam.//Como a água do rio/que é água sempre nova.//Como cada dia/que é sempre um novo dia.//Vamos brincar de poesia? In Poemas para brincar, São Paulo: Ática, 1990.
} 


\section{Referências}

\section{EM SUPORTE IMPRESSO}

ADAM, J.M. Pour lire le poeme - Introduction à l'analyse du type textuel poétique. Bruxelas, Ed. A de Boeck Duculot, 1985.

AGUIAR E SILVA, Vitor Manuel. Teoria da Literatura. $3^{\mathrm{a}}$ ed. rev. e aum. Coimbra: Almedina, 1979.

ALTENFELDER, Anna Helena. Poetas da escola. Coordenação técnica: Centro de Estudos e Pesquisas em Educação, Cultura e Ação comunitária. São Paulo: Peirópolis, 2004.

AMOSSY, Ruth (org.). Imagens de si no discurso - A construção do ethos. Tradução: D.F.C. São Paulo: Contexto, 2005.

ANDRADE, Carlos Drummond de. Alguma Poesia. Rio de Janeiro: Record, 2001.

BAKHTIN, Mikhail. Sobre Maiakóvski. In BRAIT, Beth (org.). Bakhtin, dialogismo e polifonia. São Paulo: Contexto, 2009, p. 191-204.

. Estética da Criação Verbal. Introdução e tradução do russo: Paulo Bezerra; prefácio à edição francesa: Tzvetan Todorov. $4^{\mathrm{a}}$ ed. São Paulo: Martins Fontes, 2003

. O problema do conteúdo, do material e da forma na criação literária. (1924) In: Questões de literatura e de estética - A teoria do romance. São Paulo: Hucitec, 1988, p. $13-70$.

BAKHTIN, M.; VOLOSHINOV, V.N. Discurso na vida e discurso na arte (sobre poética sociológica) (1926) Tradução de Carlos Alberto Faraco e Cristovão Tezza da edição americana de I. R. Titunik "Discourse in life and discourse in art - concerning sociological poetics", publicada em V. N. Voloshinov, Freudism, New York. Academic Press, 1976. Circulação restrita.

BANDEIRA, Manuel. Itinerário de Pasárgada. $4^{\mathrm{a}}$ ed. Rio de Janeiro: Nova Fronteira; Brasília: INL, 1984. 
BARBOSA, Jacqueline Peixoto. Trabalhando com os Gêneros do Discurso: Uma Perspectiva Enunciativa para o Ensino de Língua Portuguesa. Tese de Doutoramento. São Paulo: LAEL / PUC-SP, 2001.

BAZERMAN, Charles. Gêneros textuais, Tipificação e Interação. Organização: Angela Paiva Dionísio e Judith Chambliss Hoffnagel. Tradução e Adaptação: Judith Chambliss Hoffnagel. Revisão técnica Ana Regina Vieira [et al.]. São Paulo: Cortez, 2005.

- Gênero, Agência e Escrita. Organização: Angela Paiva Dionísio e Judith Chambliss Hoffnagel. Tradução e Adaptação: Judith Chmbliss Hoffnagel. São Paulo: Cortez, 2006.

. Escrita, Gênero e Interação Social. Organização: Judith Chambliss Hoffnagel e Angela Paiva Dionísio. Tradução e Adaptação: Judith Chmbliss Hoffnagel (resp.). São Paulo: Cortez, 2007.

BERALDO, Alda. Trabalhando com poesia vol. 1. São Paulo: Ática, 1990.

BORDINI, Maria da Glória. Poesia Infantil. 2a ed. São Paulo: Ática, 1991. Série Princípios, 97.

BOSI, Alfredo. O ser e tempo da poesia. São Paulo: Cultrix/ Edusp, 1977.

BRASIL. MEC. SEF. Parâmetros Curriculares Nacionais: primeiro e segundo ciclos do ensino fundamental - Língua Portuguesa. Brasília: MEC / SEF, 1997.

BRASIL. MEC.SEF. Parâmetros Curriculares nacionais: terceiro e quarto ciclos do ensino fundamental - Língua Portuguesa. Brasília: MEC / SEF, 1998.

BRASIL. MEC. SEMTEC. Secretaria de Educação Média e Tecnológica. Parâmetros curriculares nacionais: Ensino médio - linguagens, códigos e suas tecnologias. Brasília: MEC / SEMTEC, 2000.

CAMPOS, Haroldo de. Comunicação na poesia de vanguarda. In A arte no horizonte do provável e outros ensaios. $2^{\text {a }}$ ed. São Paulo: Editora Perspectiva, 1969.

CANDIDO, Antonio. O estudo analítico do poema. $5^{\mathrm{a}}$ ed. São Paulo: Associação Editorial Humanitas, 2006. 
CHARADEAU, Patrick; MAINGUENEAU, Dominique. Dicionário de análise do discurso. Coordenação de tradução: Fabiana Komesu. São Paulo: Contexto, 2004.

CIARDI, John. Ciardi Himself: fifteen essays in the reading, writing, and teaching of poetry. Fayetteville: The University of Arkansas Press, 1989.

COLASANTI, Marina. Fino Sangue, Rio de Janeiro: Record, 2005.

COSEM, Michel (org.) O poder da poesia. Trad. Maria Helena Arinto. Coimbra: Almedina, 1980.

COSTA, Jorge Campos da. "A Teoria inferencial das implicaturas: descrição do modelo clássico de Grice”. In Letras de Hoje, Porto Alegre, v. 44, n. 3, p. 12-17, jul./set. 2009.

DISCINI, Norma. "Ethos e estilo". In MOTTA, Ana Raquel e SALGADO, Luciana (orgs.). Ethos discursivo. São Paulo; Contexto, 2008.

D’ONOFRIO, Salvatore. Forma e sentido do texto literário. São Paulo: Ática, 2007. Ática Universidade.

FARACO, Carlos Alberto. “Autor e Autoria”. In BRAIT, Beth (org.) Bakhtin: conceitos chave. São Paulo: Contexto, 2005.

FIAD, Raquel Salek. "Ensino e autoria". In TFOUNI, Leda Verdiani (org.) Múltiplas faces da autoria. Ijuí: Ed. Inijuí, 2008. Coleção Linguagens.

FIORIN, José Luiz. Introdução ao pensamento de Bakhtin. São Paulo: Ática, 2006.

FREITAS, José Carlos de. O Ensino de Poesia na Escola. Revista Espaço da Sophia. no ${ }^{12}$, ano I, março / 2008.

GEBARA, Ana Elvira L. A poesia na escola. Leitura e análise de poemas para crianças. São Paulo: Cortez, 2002. Coleção Aprender e Ensinar com Textos, vol.10.

GOLDSTEIN, Norma (Org.) Traços marcantes no percurso poético de Manuel Bandeira. São Paulo: Humanitas, 2005.

.Gênero poético: uma proposta em espiral para o ensino fundamental. Revista Filologia e Lingüística Portuguesa, v. 8, p. 361-377, 2006. 
. Versos, sons, ritmos. $14^{\mathrm{a}}$ ed. rev. e atualizada. São Paulo: Ática, 2007. Série

Princípios, 6

GOLDSTEIN, N. S.(org) ; LOUZADA, M. S. O. ; IVAMOTO, R. M. F. E. . Português $6^{\circ}$. a 9. ano [coleção didática]. São Paulo: Pueri Domus Escolas Associadas, 2009. v. 4.

GRILLO, Sheila V. de Camargo. Esfera e campo. In BRAIT, Beth (org.). Bakhtin: outros conceitos-chave. São Paulo: Contexto, 2006.

JAKOBSON, Roman. Linguística e poética. In Linguística e comunicação. São Paulo: Cultrix, 1969.

JEAN, Georges. Na escola da poesia. Tradução: Maria Carvalho. Lisboa: Instituto Piaget, 1995. Colecção Horizontes Pedagógicos.

JOLIBERT, Josette (coord.). Formando crianças leitoras. Trad. Bruno C. Magne. Porto Alegre: Artes Médicas, 1994. volume I.

Formando crianças produtoras de texto. Trad. Walkiria M.F. Settineri e Bruno C. Magne. Porto Alegre: Artes Médicas, 1994a. volume II.

JOLIBERT, Josette; SRAÏKI, Christine. Caminhos para aprender a ler e escrever. Tradução Ângela Xavier de Brito. Revisão técnica Maria Manuela de Castro Mendes Leal Anabuki. São Paulo: Contexto, 2008.

JOLLES, André. Formas simples - legenda, saga, mito, adicinha, ditado, caso, memorável, conto, chiste. Trad. Álvaro Cabral. São Paulo: Cultrix, 1976.

KLEIMAN, Ângela B. "Processos identitários na formação profissional - O professor como agente do letramento" In CORRÊA, Manoel Luiz Gonçalves; BOCH, Françoise (orgs.). Ensino de língua: representação e letramento. Campinas (SP): Mercado de Letras, 2006. (Coleção idéias sobre linguagem).

KOCH, Ingedore Villaça. A coesão textual. $18^{\mathrm{a}}$ ed. São Paulo: Contexto, 2003.

KOCH, Ingedore Villaça; TRAVAGLIA, Luiz Carlos. A Coerência Textual. $17^{\mathrm{a}}$ ed. $2^{\mathrm{a}}$ reimpr. São Paulo: Contexto, 2008.

LAJOLO, Marisa. Usos e abusos da Literatura na Escola. Bilac e a Literatura Escolar na República Velha. Rio de Janeiro: Globo, 1982. 
LEMINSKI, Paulo. La vie en close. $4^{a}$ reimpr. da $5^{a}$ ed. de 1994. São Paulo: Brasiliense, 2004.

LERNER, Delia. Ler e escrever na escola: o real, o possível e o necessário. Prefácio de Emilia Ferreiro. Trdução de Ernani Rosa. Revisão Técnica de Telma Weisz. Porto Alegre: Artmed, 2008 (reimpr.)

LEVIN, Samuel R. Estruturas Linguísticas em poesia. Tradução: José Paulo Paes. São Paulo: Cultrix, Editora da Universidade de São Paulo, 1975.

LIRA, Pedro. Conceito de poesia. São Paulo: Ática, 1986. Série Princípios, 57.

MAINGUENEAU, Dominique. Pragmática para o discurso literário. $2^{\mathrm{a}}$ Ed. Tradução de . São Paulo: Martins Fontes, 2002.

. Cenas da Enunciação. Sírio Possenti; Maria Cecília Pérez de Souza-Silva (orgs.). Tradutores: Sírio Possenti; Maria Cecília Pérez de Souza-Silva, et al. Curitiba: Criar Edições, 2006.

. Discurso literário. Tradução de Adail Sobral. São Paulo: Contexto, 2006a.

. A propósito do ethos. Tradução de Luciana Salgado. In MOTTA, Ana Raquel, SALGADO, Luciana (orgs.) Ethos discursivo. São Paulo: Contexto, 2008.

MARTINS, Nilce Sant'anna. Introdução à Estilística: a expressividade na língua portuguesa. São Paulo: T.A. Queiroz: Editora da Universidade de São Paulo, 1989. Biblioteca universitária de língua e linguística, vol. 8.

MATÊNCIO, Maria de Lourdes Meirelles. "Letramento na formação do professor Integração a práticas discursivas acadêmicas e construção da identidade profissional" In CORRÊA, Manoel Luiz Gonçalves; BOCH, Françoise (orgs.). Ensino de língua: representação e letramento. Campinas (SP): Mercado de Letras, 2006. (Coleção idéias sobre linguagem).

MELLO, José Geraldo Pires. Teoria do ritmo poético. 2a ed. Brasília: UniCEUB, 2001.

MICHELETTI, Guaraciaba (coord.) Aprender e ensinar com textos didáticos $e$ paradidáticos. São Paulo: Cortez Editora, 1997. Coleção Aprender e Ensinar com Textos, v. 2. 
. Leitura e construção do real: o lugar da poesia e da ficção. São Paulo: Cortez, 2000. Coleção Aprender e Ensinar com Textos; v. 4.

MOSCOVICI, Serge. Representações sociais: investigações em psicologia social. $5^{\mathrm{a}}$ ed. Editado em inglês por Gerard Duveen. Traduzido por Pedrinho Guareschi. Petrópolis (RJ): Vozes, 2007.

Na Ponta do lápis. Almanaque do programa Escrevendo o futuro. n³ março/abril, 2006.

PADILHA, Simone de Jesus. Os Gêneros Poéticos em Livros Didáticos de Língua Portuguesa do Ensino Fundamental: uma abordagem enunciativo-discursiva. Tese de Doutoramento. São Paulo: LAEL / PUC-SP, 2005.

PAES, José Paulo. Poemas para brincar. São Paulo: Ática, 1990. . Quem, eu? Um poeta como outro qualquer. Coord. Vivina de Assis Viana. São Paulo: Atual Editora, 1995. (Coleção Passando a limpo). . Poesia para crianças - um depoimento. São Paulo: Editora Giordano, 1996.

PAZ, Octavio. Signos em rotação. São Paulo: Perspectiva, 1996. Debates, 48.

PESSOA, Fernando. O Eu profundo e os outros eus: seleção poética. $9^{\text {a }}$ ed. seleção e nota editorial Afrânio Coutinho. Rio de Janeiro: Nova Fronteira, 1980.

PINHEIRO, Hélder. Poesia na sala de aula. João Pessoa: Idéia, 1995.

PINHEIRO, Hélder (org.). Poemas para crianças: Reflexões, experiências, sugestões. São Paulo: Livraria Duas Cidades, 2000. Coleção Literatura e Ensino; 1.

- Abordagens de um poema: Roteiro de um desencontro. In: DIONÍSIO, Angela Paiva; BEZERRA, Maria Auxiliadora (orgs.) O Livro Didático de Português. Múltiplos Olhares. $2^{\mathrm{a}}$ ed. $1^{\mathrm{a}}$ reimpr. Rio de Janeiro: Editora Lucerna, 2003.

PINHEIRO, Maria Elisa Brito Pereira. Representações de alunos do ensino médio sobre o leitor de poesia: revelação de imagens de si. In Falla dos Pinhaes. Espírito Santo de Pinhal (SP), v. 3, n. 3, jan/dez.2006.

POSSENTI, Sírio. Práticas de escrita como processos de enunciação. In MICHELETTI, Guaraciaba (org.) Enunciação e Gêneros Discursivos. São Paulo: Cortez Editora, 2008. 
RAJAGOPALAM, Kanavillil. “Traição versus transgressão: reflexões acerca da tradução e pós-modernidade”. In Alfa. Revista de Linguística. V. 44 (n. esp). 2000.

ROJO, Roxane. "Gêneros do discurso e gêneros textuais: questões teóricas e aplicadas" In MEURER, J. L.; BONINI, Adair; MOTTA-ROTH, Désirée (orgs.). Gêneros: teorias, métodos e debates. São Paulo: Parábola Editorial, 2005.

ROSENFELD, Anatol. O Teatro Épico. São Paulo: Buriti, 1965.

SANDMANN, Antonio José. Formação de palavras no Português Brasileiro Contemporâneo. Curitiba: Scientia et Labor, Ícone Editora, 1989.

SANTIAGO, Silviano. "Singular e anônimo". In Nas malhas da letra. São Paulo: Cia das Letras, 1989.

SCHNEUWLY, Bernard; DOLZ, Joaquim et alii. Gêneros orais e escritos na escola. Tradução e organização Roxane Rojo e Glaís Sales Cordeiro. Campinas, SP: Mercado de Letras, 2004. (Coleção As Faces da Linguística Aplicada).

SCHNEUWLY, Bernard; REVAZ, Françoise. Expression écrite - lire pour ecrire, écrire pour lire: une méthode pour maîtriser l'écrit. CM1. Paris: Nathan, 2002.

. Expression écrite - lire pour ecrire, écrire pour lire: une méthode pour maîtriser l'écrit. CM2. Paris: Nathan, 1994.

SCHNEUWLY, Bernard; SANDON, Jean-Michel. Expression écrite - lire pour ecrire, écrire pour lire: une méthode pour maîtriser l'écrit. CE2.Guide Pédagogique. Paris: Nathan, 2002.

SERRANI, Silvana. Discurso e Cultura na Aula de Língua - Currículo - leitura - escrita. Campinas, SP: Pontes, 2005.

SORRENTI, Neusa. A peosia vai à escola: reflexõe, comentários e dicas de atividades. Belo Horizonte: Autêntica, 2007. Coleção Formação Human na Escola, 6.

STAIGER, Emil. Conceitos fundamentais da Poética. Tradução de Celeste Aída Galeão; Revisão da parte grega de Rosa Carino Louro. Rio de Janeiro: Tempo Brasileiro, 1975.

TEZZA, Cristovão. Entre a prosa e a poesia: Bakhtin e os formalistas russos. Rio de Janeiro: Record, 2003. 
. "Poesia". In Beth Brait (org.) Bakhtin: Outros Conceitos-chave. São Paulo:

Contexto, 2006.

TODOROV, Tzvetan. Os gêneros do discurso. Tradução: Elisa Angotti Kossovithch. São Paulo: Martins Fontes, 1980.

TRAVAGLIA, Luis. A caracterização de categorias do texto: tipos, gêneros e espécies. In Revista Alpha, 51 (1), 2007, p. 39-79.

TRAVAGLIA, Luis. Gramática ensino plural. São Paulo: Cortez, 2003.

VERSIANI, Zélia. “A diversidade da produção poética para crianças e jovens”. In PAIVA, Aparecida; EVANGELISTA; Aracy, PAULINO, Graça; VERSIANI, Zélia (orgs). No fim de século: a diversidade - o jogo do livro infantil e juvenil. Belo Horizonte: Autêntica, 2000. P. 49-60.

\section{EM SUPORTE DIGITAL}

Êh São Paulo. Disponível em http://cifrantiga3.blogspot.com/2006/08/h-so-paulo.html , acesso em 06-06-2008.

Literatura de Cordel. In Enciclopédia Itaú Cultural de Literatura Brasileira. ISBN 978-8585291-72-3. Disponível em http://www.itaucultural.org.br/aplicexternas/enciclopedia_lit/index.cfm?fuseaction=definicoe

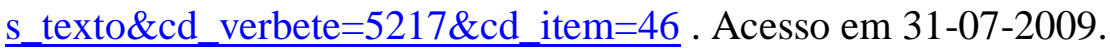

O Nordeste dos violeiros e repentistas. Entrevista de Ivanildo Vilanova a Miguel de Almeida, In Folha de São Paulo, 30-05-1982. Disponível em http://almanaque.folha.uol.com.br/musicapop1.htm Acesso em 07-06-2008

PAES, José Paulo. "Infância e Poesia" In Folha de São Paulo, 09-08-1998. Caderno Folha Mais! Disponível em http://www1.folha.uol.com.br/fsp/mais/fs09089806.htm Acesso em 1410-2009.

Poesia vira hit na troca de mensagens de celular", in O Estado de São Paulo. Caderno Link. 01-12-2004. Disponível em http://www.estadao.com.br/arquivo/arteelazer/2004/not20041201p4779.htm. Acesso em 0106-2008 
Sinfonia

Paulistana.

Disponível

em

http://www.mpbnet.com.br/musicos/billy.blanco/letras/sinfonia_paulistana.htm , acesso em 06-06-2008.

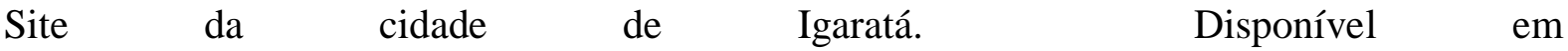
http://www.explorevale.com.br/cidades/igarata/historia.htm , acesso em 06-06-2008.

Site da cidade de Suzano. Disponível em http://www.suzano.sp.gov.br , acesso em 06-062008 .

Site oficial do cantor e compositor Flávio José. Disponível em http://www.flaviojose.com.br, acesso em 06-06-2008.

Verbete "Peculiaridade" In Dicionário Houaiss da Língua Portuguesa. Disponível em http://houaiss.uol.com.br/busca.jhtm?verbete=peculiaridade\&stype=k acesso em 06-09-2008. 
ANEXO 1 - Fascículo Poetas da Escola (reprodução xerográfica) 


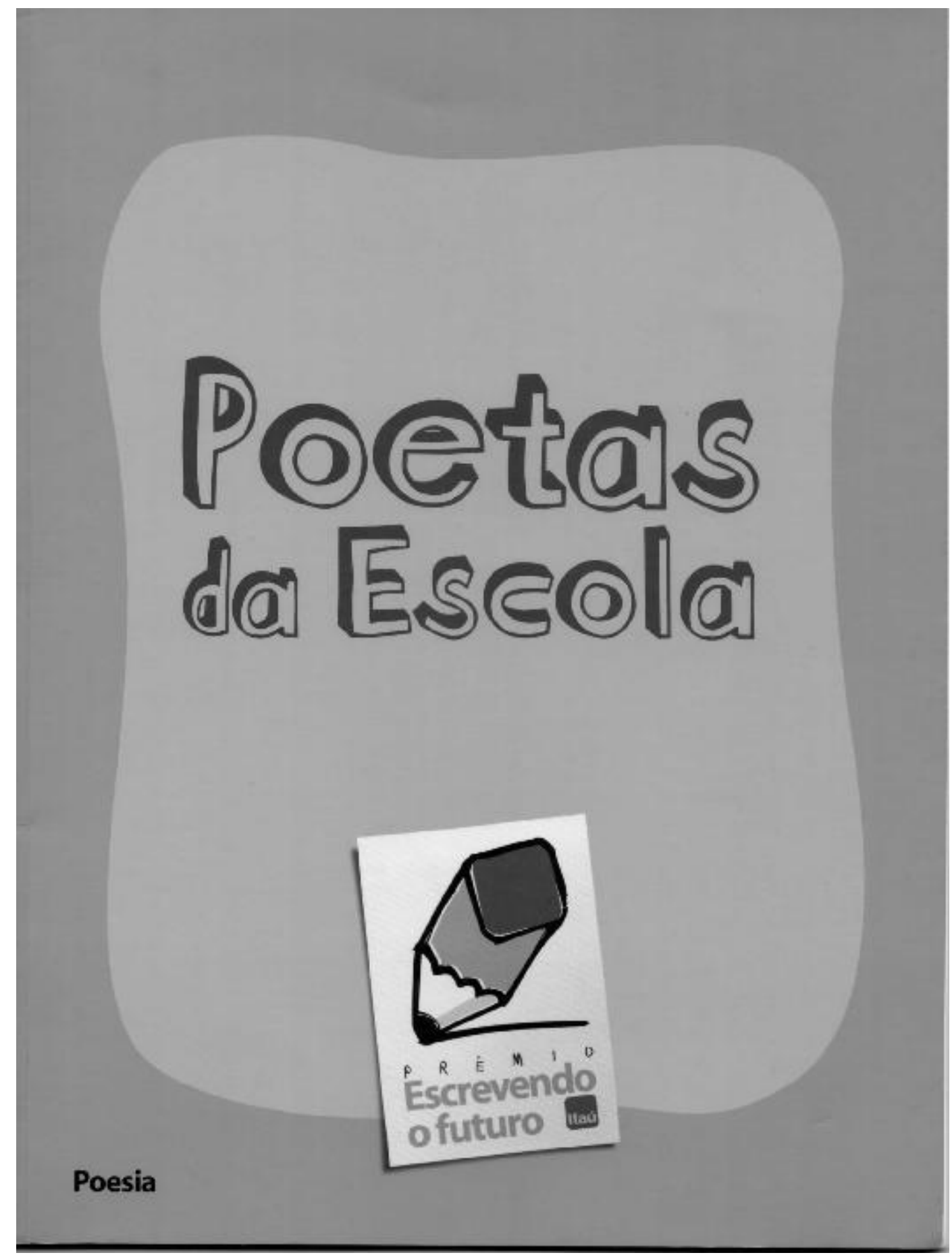




\section{Apresentação}

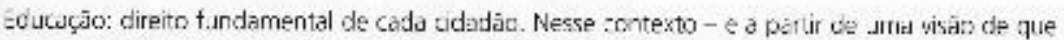
a niciat va privaca pote e deye colabcrar uyora, e no futuro, para a construço de uma srcie-dade

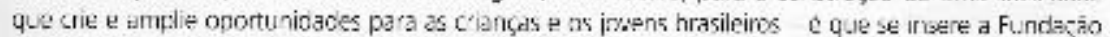
liac 5cca, diespn:onben to e apoiando prograrras na àrea de ec ucaço púbica - ensino fundamental

o Prsorama Fscrevendo o futuru è 2 resultata desse entend mento, consubstanciado am um

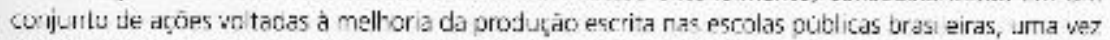
que a conquista das hahilidaces da leitura e da escrita sign tica um determinente fator de inclusao socia e de sucesso fara os joviens cidadasos na vida catidiana e no mercudo de trabaltc. Está fortemerte apoiado no conce to de parceria, zom z participacăo do M nistério de Eduracāo (MFC). co Conselha Nacoral dos Secretános de Enuraço iConsedi, ca Uniajo Na:ional dos Cirigentes Municipas da Eoucacăo Undimej, e du Carla Futura; contando ainda cem a condenacan térrica vo Centro de Estudos e PCsquisas em Educaçäo, C.ultura e Aço Comurntára (Ćenpec)

Em ancs pares, o Programa [screwends of Futurs prem a a unos, prolessores e escolas por meo de urr concarso de textos deservolvidus lids salas de ala em ofic nas de formatido. Wos aras imp:s, promove açes oara aorimorà a formaçäs drא pmfes5ores, fcrnecendu subsidios para o Sisir:a de leitura e escrita

Na frimeira ediça do Prémio sccevende o Futuro, da qual oarticiparam 4.657 parnlas de diverys estarios brasleiros, ceca de 358 mil alunos toram bencficados per meic do diversas

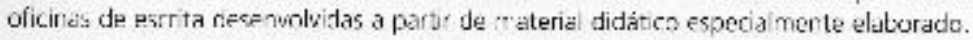

Nestu segu nce eciçăo, o Kt taù de Claçju ve Textus foi aprimorado com base nas experièncias pupil adds durarte 0 ano de 2002 e nos resulddrs nas nticinas de lomaça de Frotesscres imolementadas em 2003

Esse Kit é composto gelos fásiculus Puntes ue Vista, Poetas da Escola e 5 e bem me lembro.. p Lem cumo ob ptivs orientar os poofessores na realizaçar. ne nficinas, dsscminarudo práticas temsuccdicas no pnsinn da p5rrita

[soerdmos que o Kit Itaí ne Criaçao de lextcs sejd mes um instrumento de trabalho nds mãos Jos protess:: fundament.d do Rrasil.

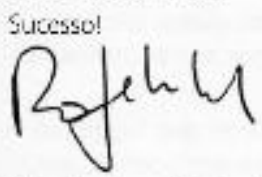

Roberto Egydio Setubal

Presidente da Fundaçăo itaú Social 


\section{Carta do professor}

\section{Caro colega,}

vocé esta 'ccebendo o Kit taú de Criaço de Textos - 2004 que orienta a elaboraçäo de textos por me o da rea izaça de oficinas de escrita, para o Prêmia fscrevendo o f rumo em sua sequnda ediça o tema sobre o qual as crianças deverăo escrever é "O luçar onde vivo"

Os óganizadores do Prémio Escrevendo o Futuro idealizaram a produçäo de algumas publicacoes: uma, de memhrias, histórias ne pešnas ne diferentes lugares do Brasil; nutra, de textes em que os alunos defendam opinióes sobre assuntos diversos; $\in$ outra, ce pcermas. Assim, sel al Jno val escolher $\mathrm{c}$ oroduzir textos bem ocfinidos: um texto de memónas, um de opin ao ou um poena.

Escrever memorias a partir de entrevistas com pessaas mais velhas sobre fo o lugar onde vivern é mu to diferente de escrever um artiģo de opiniäo ou um ooema. A elatoraçăo dacuele terrı comb finalidade apresentar lembranças de um determinado luqar para pesscas que nào viveram nessa éoca. O texto de opiniào tem como finalidade convencer alguém de alçuma coisa. Neste caso, o autor do texto assume uma posiçăc a favor ou cortra uma questäo cue prewsca discussōes, debates, como, oor exemplo, ser a favor ou contra o trabalto intantil, Já ra poesia, o autur revela a manera como ve o mundo, brincando com as palauras

Cada um desses gêneos de textos tem uma finalidade bastante difere tenham de apresentar caracteristicas bem particulares. Muitas vezes, yuando prouonics que rusisos aluncs escrevam, nan na nos a essa escrita uma finalidade rlara, nem estimularnos sua circulaçå fora da escola. Cs leitores das producóes escritas realizacas na escola säo, cuase sempre, apenas os professcres. A. redaça é -eita na escola e para a escala. 1550 contribui para padronizar as produçćes escolares, deixando-as muito parec das entre si.

A oroposta deste material parte, pois, do princípio de que as condiçčes de produçấo da escrita devem ficar claras para os alunos. Para escrever seus textos, eles devem saber dessas condiçóes desde a inicio: suas escritas teräo uma finalidade (convencer alçuèm de alguma ccisa ou resgatar o memória soare histór as ou fatos interessantes do lugar onde vijem para pessoas que querem conhecé-los ou sensibilizar o letor), será publicadas e lidas por muitas pessoas.

Tambem pensamos que, com esses esclarerimentos, será mais fảcil aos alunos compreenderem que é preciso escrever corretamente, com capricho. Afina, se sabemos que muitas pessoas irão ler nosso texto, É necessário que ele seja legivell

Preparar os alunos para esta tarefa nä́ quer dizer criar expestativas de que façam um texto muito elaboradc, como se fossem adultcs. O que se espera è que escreyam poemas, memúríss sobre o lugar once visem ou textcs de opiniz̈o que evelerr o ponto de vista deles a respeito do tema tratado. 
Organizamos algut as v vientaşoes que acreditamos sejam Uteis para auxiliar protessores e alunos nas tarefas necessarias nara praduzir um bom texto es_rito. As orientaçóes seguem o printipio ja irdicado e que corsideramas váldo nao só para a concurso, mas tarnbém para o dia-a-da na escola: as escritas sempre cevern ser feitas a partir de ura situaçao de preducāo proxima a situaçōes que ocorrern fora do espaça escular.

Como voce pade concluir, a elaboraçăa de um texto de opiniaju ou de um relato sobre as memórias de um lugar, ou de poenas, exige que vocé, em cada um dos casos, oriente diferentemente seu aluro para que a produ ̧ăo escrita seja satisfató ia

Vocess, professores, tanto quanto nas, organizadores do Prênio e autores deste malerial de apoio, somos mediadores cuja areta maior é contr buir para a melhoria da cualidace da educacăo bresileira.

Desejamos cue ncssas s.jgestoes ocssam ser utes s eue trodos se empolguem com a participaçăo no concurso, trabaherm bastante animadas e tenham muita sorte!

Bom trabalhol

\section{As autoras}




\section{Sumário}

\section{Oficinas}

I Reconhecendo poesia

2 Sabendo um pouco mais sobre poesio 10

3 Produção individual 16

4 Catadores de poemas 18

5 Ouvindo, lendo e conhecendo um pouco mais de poesia 22

6 Brincando com as emoçōes e as palavras 25

7 Brincando um pouco mais com as palavras:
rimas, repetiçose aliteraçōes.

8 Conhecendo poesia popular 33

9 Vendoo mundo de um modo poético 38

10 Analisando diferentes olhares sobre o mesmo tema 42

II Reconhecendo emoçōes e sentimentos, tornando-se poeta 46

12 Tecendo poemas 49

13 Dando o toque final aos poemas 54

Palavras (quase) finais 


\section{Apresentação do aluno}

Você, professor, já foi apresentado ao Programa Escrevendo o Futuro e conhece a finalidade, a proposta, os objetivos, a metodologia e os passos necessórios para se chegar à premiaçäo.

Imagne se o presente material nōo trouxesse tadas estas explicaçōes para você: Com certeza, scria difícil coordenar atividades cujos propbsitos e procedimentos nõo estivessem claros e definidos.

O mesmo ocorre com os alunos. Muitas vezes, mostram-se desinteressados ou pouco envolvidos nas propostas, por nào saberem exatamente o porquê daquilo que estão fozenda.

Sugerimos, paro iniciar a converso, que você apresente o Programa Escrevendo - Futuro, falando de suas vórias etapas e o produto final: um poema cujo tema é "O lugar onde eu vivo" que concorreré ao prêmio da Ediçao 2004. Para isso você pode se basear na apresentaçào do material e na introdução deste fascículo. É importante ressaltar para seus alunos os objetivos e a organização do trabalho, e que as oficinas propostos pretenden ajuda-los a obter sucesso no tarefo final.

Como muitos atividades pressupỏem trabalho em grupo e uma certo independencia e autonomia por parte dos rlunos, è importante também fazer os "combinados", ou seja, regras e normas de organizaçao que deverào ser observudus pelos clunos e cobradas por voce. Esses combinados deveroo ser construidos em conjunto, porém, E suc tarefa que sejam observados e cumpridos por todos. Se necessário, retome-os en cada etapa.

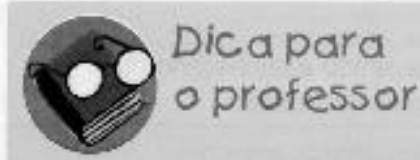

O material contém treze unidades com notas explicativas, intituladas "Para saber mais", em sua maioria, baseadas em textos escritos por Ana Maria Machado, Ferreira Gullar e Marisa Lajolo, que, assim como outros poetas, escritores e educadores, apresentam ao leitor os livros de poesia que fazem parte de várias das coleçỏes do Programa Literatura em minha casa. Antes de iniciar as oficinas, recomendamos que voce se familiarize com esses livros, lendo nào só os poemas, mas também a introduçāo, a apresentaçăo, a biografia dos poetas, o glossário, a carta ao leitor: enfim, os textos explicativos que, com certeza, auxiliarão muito o desenvolvimento das atividades. Há também um resumo das oficinas para que você tenha uma visão geral do Projeto. 


\section{Quadro-sintese das oficinas}

\begin{tabular}{|c|c|c|}
\hline & Oficina & Objetivo \\
\hline 1 & Reconhecendo poesia & $\begin{array}{l}\text { Resgatar a exoeriência dos alunos, } \\
\text { possibilitando o reconhecimento das } \\
\text { diversas formas de expressāo da poesia } \\
\text { no cotidiano. }\end{array}$ \\
\hline 2 & Sabendo um pouco mais sobre poesia & $\begin{array}{l}\text { Refletir sobre as caracteristicas da poesia, } \\
\text { definindo e diferenciando alouns conceitos } \\
\text { do universo poético (poesia, ooemas, rimas, } \\
\text { versos, estrofes). }\end{array}$ \\
\hline 3 & Produçāo individ..jal & $\begin{array}{l}\text { Propor a produça de um primeiro } \\
\text { poema para avaliar o que os alunos.a } \\
\text { sabern e os pontos que precisam ser mais } \\
\text { trabalhados. }\end{array}$ \\
\hline 4 & Catadores de poemas & $\begin{array}{l}\text { Pesquisar poemas conhecidos pelas pessoas } \\
\text { das comunidades onde vivem os alunos. }\end{array}$ \\
\hline 5 & $\begin{array}{l}\text { Ouvindo, endo e conhecendo um } \\
\text { pcuco mais de poesia }\end{array}$ & $\begin{array}{l}\text { Conhecer alguns poernas consagrados da } \\
\text { língua portuguesa. }\end{array}$ \\
\hline 6 & $\begin{array}{l}\text { Bnrcando com as emoçōes } \\
\text { e as palavras }\end{array}$ & $\begin{array}{l}\text { Sensibilizar o aluno para perceber, } \\
\text { identificar e criar rimas. }\end{array}$ \\
\hline 7 & $\begin{array}{l}\text { Er ncando um pouco mais com as } \\
\text { palavras: rimas, repetiçós e alite açcoes }\end{array}$ & $\begin{array}{l}\text { Identificar o uso dos recursos pó́ticos: rma, } \\
\text { aliteraçấc e repetiçăo de versos. }\end{array}$ \\
\hline 8 & Conhecendo poesia popular & $\begin{array}{l}\text { Familiarizar o aluno com poes a popular e } \\
\text { com mais um recurso oośtico: o acróstico. }\end{array}$ \\
\hline 9 & Verco o mundo de um modo poético & $\begin{array}{l}\text { Possibilitar a dentificaçào e a criaçăc de } \\
\text { comparaçoes, imagens e metáforas } \\
\text { em poemas. }\end{array}$ \\
\hline 10 & $\begin{array}{l}\text { Analisando diferentes olhares sobre } \\
\text { o mesmo tema }\end{array}$ & $\begin{array}{l}\text { Conhecer poemas de diferentes autores } \\
\text { sobre um mesmo tema - "O lugar onde } \\
\text { vivem ou viveran os poetas". }\end{array}$ \\
\hline II & $\begin{array}{l}\text { Reconhecendo emoçōes e sentimertos, } \\
\text { tornando-se poetd }\end{array}$ & Elaborar poemas em pequenos grupos. \\
\hline 12 & Tecendo poernas & Produzir a escrita individual. \\
\hline 13 & Dando o toque final aos poemas & Rever os poemas produzidos. \\
\hline
\end{tabular}




\section{Oficina I}

\section{Reconhecendo poesia}

\section{Objetivos}

17. Resgatar a exoeriència das alunus com poes a.

38. Passit litar o recenhecimento da poesia em suas diversas formas de expressao no cotidiano.

Ampliar a repertóna dos alunos.

- Mancjar c iniciar a organizaçao do Mura de Poesia.

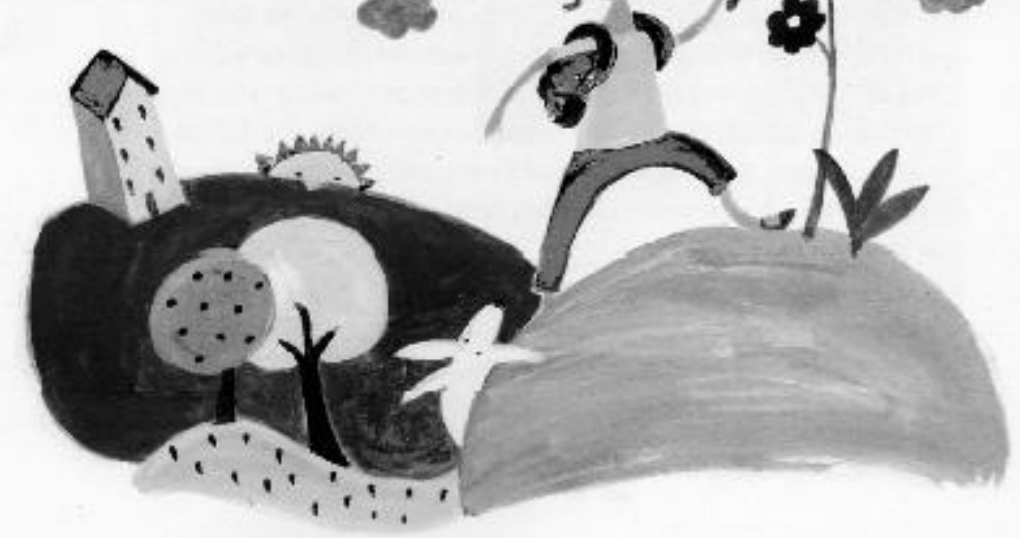




\section{Conversa com o professor}

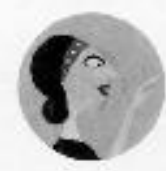

Vamos trabalhar com poesia. Certamente, seus alunos já leram ou ouviram poemas.

Cançōes, poemas, cantigas de roda, parlendas, trava-linguas que fazem parte de 5 uas brincadeiras, os músicas que ouverne cantam, ou repentes, quadras e cordel - tudo isso pade ser considerado poesia.

Nosso propósito nesta oficina é observar as poesias trazidas pelos alunos para planejar a ampliação do repertório deles. Assim, se a maioric conhece, por exemplo, apenas parlendas, quadras, poemas infantis, e importante apresentar para o grupo a poesia clássica. Se, por outro lado, o repertório das crianças se concentra na poesia erudita, é necessario mostrar-lhes a poesia popular, e assim por diante. O levantamento do repertório serve, portanto, para cado professor saber em que pontos deve enfatizar mais o trabalho, de modo que os alunos possam compreender e apreciar mais e melhor a poesia.

Vocé náo acha que seria interessonte um registro de tudo o que vào aprender? Nosso sugestào é montar um mural na sala para que. co final do percurso, a classe disponha de uma coletânea dos poemas conhecidos, dos descobertos, dos preferidos, e das aprendizagens sobre o que é poesia. Propomos que se inicie a montagern do mural após a primeiła oficina e que ele seja ampliado no decorrer do processo.

O registro é um dos mais importantes instrumentos de aprendizagem e aperfeiçoamentu da prática docente. Registrar a prática nem sempre é uma tarefa fácil. Precisamos vencer a falta de tempo, de hábito. Porém, ao escrever, muitas vezes nos damos conta do que jás sabemos, descobrimos soluçāes, levantamos hipoteses ou formulamos questōes que vāo nos levar a novas aprendizagens.

Suger imos, entāo, que você registre as oficinas: relate as atividades desenvolvidas, suas impressōes, tacilidades, dificuldades, a redşāo do grupo; enfim, o processo vivido, pois, como nos diz Madalena Freire, "o registrar de sua reflexäo cotidiana significa abrir-se para seu processo de aprendizagem". 


\section{Atividades}

Divida a classe em grupas de quatro ou cinco clunos. Cada grupo vai conversar pora compartilhor lembranças de poemas que cards aluno conhexe.

O grupo deve esco her um relator que vai contar para a classe toda a conversa. Relacione na lousa o título dos poemas e/ou os versos lembrados nelus alunos.

15. Peça que cada grupo escolha um dos poemas e transcreva-o numa folha de papel essa serúa primeira produção a integrar o mural.

5. Proponha, entào, a construção do mural. Converse com os alunos para planejar a organizaçao. Onde ele vai ser colocodo? Como deixá-lo bem bonita e caprichado?

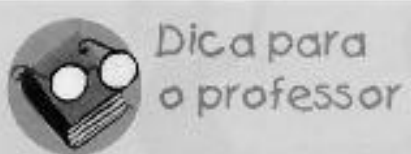

Ė importante enfatizar o "visual" do mural. Ele pode ser enfeitado, bern caprichado, mas e essencial tambèm que seja organizado de maneira que não dificulte a leitura dos poemas expostos. Afinal, poesia e poerna são a alma do projeto, a razáo de ser do mural...

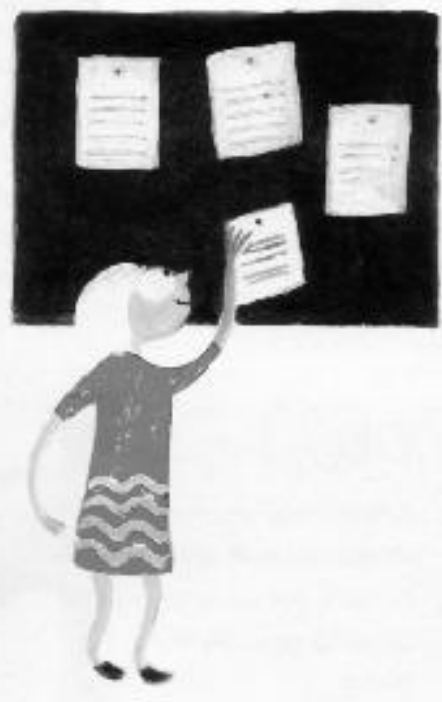




\section{Oficina 2}

Sabendo um pouco mais sobre poesia

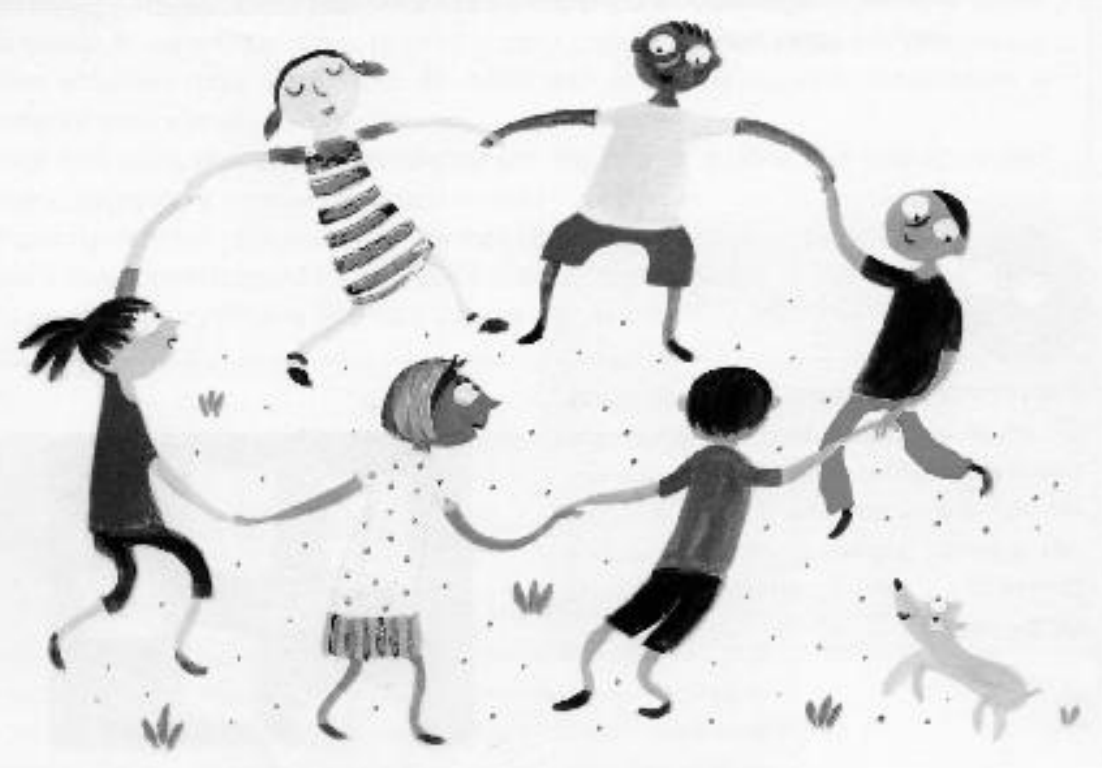

\section{Objetivos}

Retletir sabre algumas caracteristicas de um poera. Definir e diferenciar alguns conceitos do uriverso da posia. 


\section{Conversa com o professor}

Depois de resgatar a experiência dos alunos com poesia (os poemas de que eles se recordam e que agora jú estāo no mura), é hora de pensar em algumos características da poesia. A idéia nāo é dar uma aula tébrica ou explicativa, mas promover uma conversa que familiarize os alunos com alguns aspectos da poesia que sejam fundamentais para se discutir e trabulhar os novos poemas que vão conhecer.

Você pode fazer as perguntas propostas 005 poucos. Provoque os alunos para que penserm, troquern idélus, tirem conclusōes, busquem informaçōes...

Seu papel é coordenar o debate. Organize a vez de cada um falar, questione afirmaçōes. Na medida em que for necessário, de informaçoes sobre o que $\delta$ poesia, poema, rima, versos, estrofes. Faça relaçōes entre as experiências de cada um deles e us informaçōes novas, ajude-os a relacionar o que estâo descobrindo e o que ja sabern. No final, feche a atividade organizando e sistematizando as idéias discutidas pelo grupo.

\section{Atividades}

7. Observe o mural junto com os alunos e proponho um debate que aborde as seguintes questōes: por que escolhemos esses poemas? Como sabemos que esses textos são poesio? Em que eles são diferentes de uma notícia de jornal, de uma receita culinária e de um conto de fadas?

14 Como eles se organizam no papel? Eles preenchem todo o espaço das linhas, da margem esquerda à direito? Eles pulam linhas? Quais características têm em comum? De que tratam?

5. Dando prosseguimento ao projeto de familiarizar os alunos com conceitos básicos de poesia, transcreva na lausa o poema Tem tudo a ver. de Elias José, pág. 13.

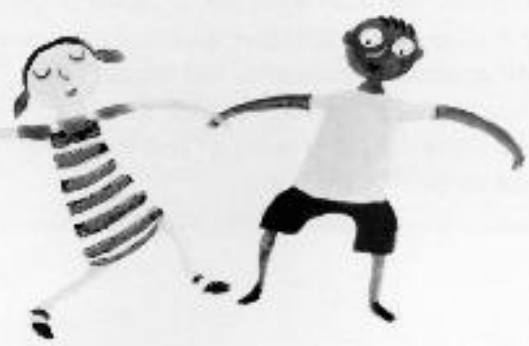




\section{Para saber mais}

Quando lemos um poema, geralmente o identificamos pela farma como ele e organizado graticamente, ou seja, como a escrita se organiza na folha: o texto usualmente é curto, cabe em uma página. Os versos (linhas do poema) săo escritos um embaixo do outro, alinhados à margem esquerda ou dispostos no centro da página, e muitas vezes não chegam até a margem direita. Pode haver espaços em branco entre as linhas e ao redor delas. Normalmente, o titulo e o nome do autor são apresentados no alto.

É importante ressaltar que esse é o formato mais comum, porém existem muitas variaçāes, por exemplo, poemas que ocupam várias páginas, como os cordèis, ou poetas que dispoem os versos, palavras e atế letras de muitas maneiras diferentes. Marisa Lajolo, em sua carta aos leitores, no livro Paiauras de encantamento, nos fala de poesia, poemas e poetas.

"[.. T possia nàs tem hoje nen ontem. Pcesia è sempre. Pocsia orincs com a linguagem."

"[... Jum poema é umn joga com a linguagem. Compoe-se de palauras: falavras soltas, pa avras em vill-adas, palavras em fia, palavras desenhadas, palavras em ritra diferente da tala ds dia-a-dia. Além de diferentes pea sonoridade e pela disposiçäo ra pägina, os poemas representam uma maneira criginal de ver o mundo, de dizer coisas. [... $]^{\times}$ "I. . poeta $e$, assim, quem descobre e far poesia a respeito de tuda: de gente, de bicho, de planta, de coisas do clia-a-dia da vida da gerete, de um brincueda, de ppiscas que parecem com pessoas que conhecemos, de episódas que nunca imagnamos que poderiam acontecer e atè de própria poesial [... $]^{2}$

"[... poeta brinca com as palsuras... parece quะ o poeta diz a rule a gente nunca tinha pensado dizer [.... $]^{\circ}$

Todos sabemos que poeta é quem escreve poesia, quem faz poemas. Mas qual é a diferença entre poesia e poema?

Vamos lá: poesia, segundo o Minidicionário Aurélio da lingua portuguesa, é a "arte de criar imagens, de sugerir emoçōes por meio de uma linguagem em que se combinam sons, ritmos e significados". Poema é definido como: "obra em verso ou náo em que hả poesia".

Ou seja: quando falamos em poesia, estamos falando de uma arte e, quando falamos em poema, estamos nos referindo a um texto concreto. Outra forma de diferenciar poesia de poema é dizer que a primeira expressāo refere-se àquilo que torna um poema ou um texto poético. Complicado? Um pouco. Talvez fique mais claro se refletirmos que, por exemplo, para trabalhar com poesia com nossos alunos (arte em geral), utilizaremos, entre outros, o poema "Tem tudo a ver" de Elias José, um texto específico transcrito na página seguinte. 
Jem tuda a ver

Elios josé

A pacsia

Jem tuda a ver

Cam tua dar e alegrias,

Cam as cares, as farmas, as cheiras.

O1 satares e a música

Da munda.

A paesia

Jem tuda a ver

Cam a sarrisa da eriança,

O diálaga das namaradas,

As lagrimas diante da marte, Os alhas pedinda pãa.

\section{A paesia}

Jem tuda a ver

Can a plumagem, a vâa e a canta,

$A$ velaz acratacia das peixes,

As cares todas da area-iris.

O ritma das rias e cachoeiras.

O Brilha da lua, da sal e das estrelas,

A explasäa em verde, em flares e frutas.

A paesia

- esó alrir as athas e ver -

tem tuda a ver

cam tuda.

patoros de encantamenica. Soo Paulo: Moderna, 2001 v. 1. p. 35.

(Programe Literotura ern minu cosa)

- Pergunte aos alunos se gostaram desse poemo. Sobre o que ele fala? Por que o autor diz que poesia tern tudo a ver com tudo' $O$ que os poemas podem exprimir? Afinal, poesia "tem a ver" com a quê?? 
- Depois de discutir com o grupo n conteúdo do poema "Tem tudo a ver", incentive os alunos a pensar nos recursos que o autor usou para compô-lo, perguntando: esse poema tem rimas? Podem-se compor poemos sem rima?

F. Apresente agora duas palavras frequentes quondo se fala de poesia. Quem sabe o que querem dizer "verso" e "estrofe"?

\section{बे) Parasaber mais}

Rimas: palavras que rimam săo palavras que se combinam, pois têm o mesmo som no final. A rima é um dos muitos recursos que os poetas usam, mas nem todo poema precisa ser rimado.

Antigamente havia formas fixas para escrever versos. O poeta devia seguir uma regra definida que determinava o esquema das rimas ou o nummera de sllabas de cada verso. Hoje, porèm, já năo é assim: o poeta pode seguir ou näo formas fixas e definidas. Nem por isso deixa de fazer poesia.

7. Diga oos alunos que o

poema Tem tudo a ver, de Elias José, tem 24 versos e quotro estrofes. Lance um desafio: será que conseguem definir o que é verso e o que $\delta$ estrofe? Sugira que conversem em pequenos grupos e tentem chegar a uma conclusào.

7. Solicitc a cada grupo que apresente suas conclusōes.

6. Peço agora que selecionem o verso do poema de que mais gostaram.

4 Complete a otividade, "pinçando" a conclusão de cada grupo que mais se aproxime da definiçāo correta de verso e de estrofe. Observando o mural, identifique junto com os alunos versos e estrofes dos poemas lú ulixados.

* Pergunte o que aprenderam sobre poesia. Faça com eles (os alunos falam e você escreve) uma lista de tudo o que aprenderam sobre poesia.

5. Encarregue cada grupo de copiar um item em uma tira de papel. Sugira, então, que organize as tiras no mural.

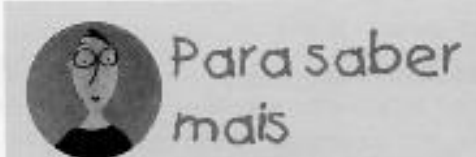

Verso è cada uma das linhas de um poema. Estrofe é cada conjunto de versos separado de outro conjunto de versos por um espaço. Um poema pode ter uma ou várias estrofes, e cada estrofe, um número variado de versos. 


\section{Dedo de prosa}

Professor, lidar com poesia, viver em meio a poemas dá outro rumo ao cotidiano. A leitura de poemas e o prazer resultante dela giram o foro do mundo, da vida. $O$ que antes era sério virou brincadeira. $D$ que antes era assim ficou assado. E assim, assado, e assim por diante... e esse o espirito ou o sentimento com que, neste projeto, vocé e us alunos iräo mudar a vida da escola. E de cada um.

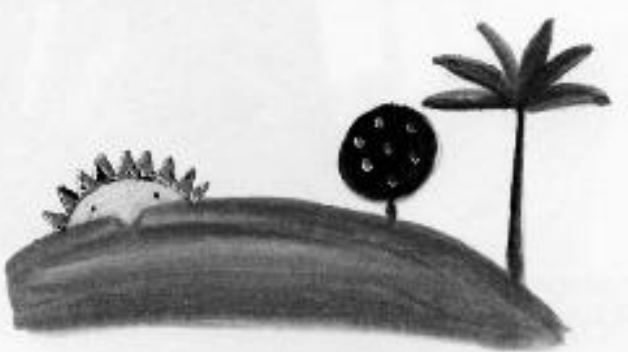


Oficina 3

Produção individual

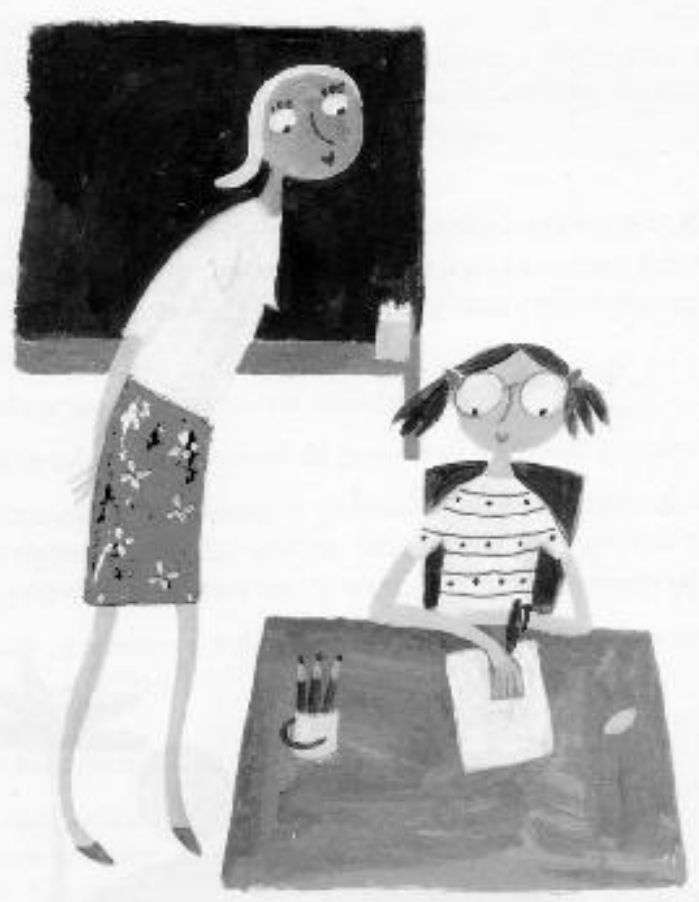

Objetivo

4 Prcoo a procucén de urr primeira pcena. 


\section{Conversa com o professor}

Cansideramos importante, neste momento, pedir que as crianças escrevam um poema. Talvez vocểesteja pensando: por que pedir uma produção escrita logo no início? Não vai ser difícil? Pode ser, mas a icléia é exatamente fazer uma comparaçāo entre o que os alunos conseguem fazer antes $\mathrm{e}$ depois de ter passado por uma seqüencia de atividades que tếm como objetivo capacita-los a escrever poemas.

\section{Atividades}

Diga para eles que nos próximos dias serao propostas várias atividades para ajudá-los a conhecer melhor poesia, mas, antes disso, você irú pedir que façam um poemo. Diga que você guardará o texto para, no final, comparar com a produçāo posterior. A intençāo é verificar as mudanças ocorridas.

34. Distribua uma folha de papel para cada aluno e peça que escrevam um poemo com o tema "O lugar onde vivo".

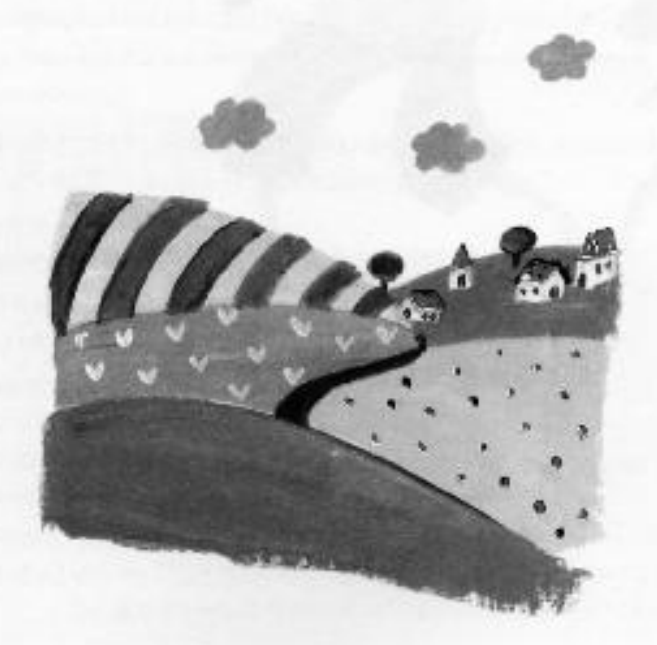




\section{Oficina 4}

Catadores de poemas

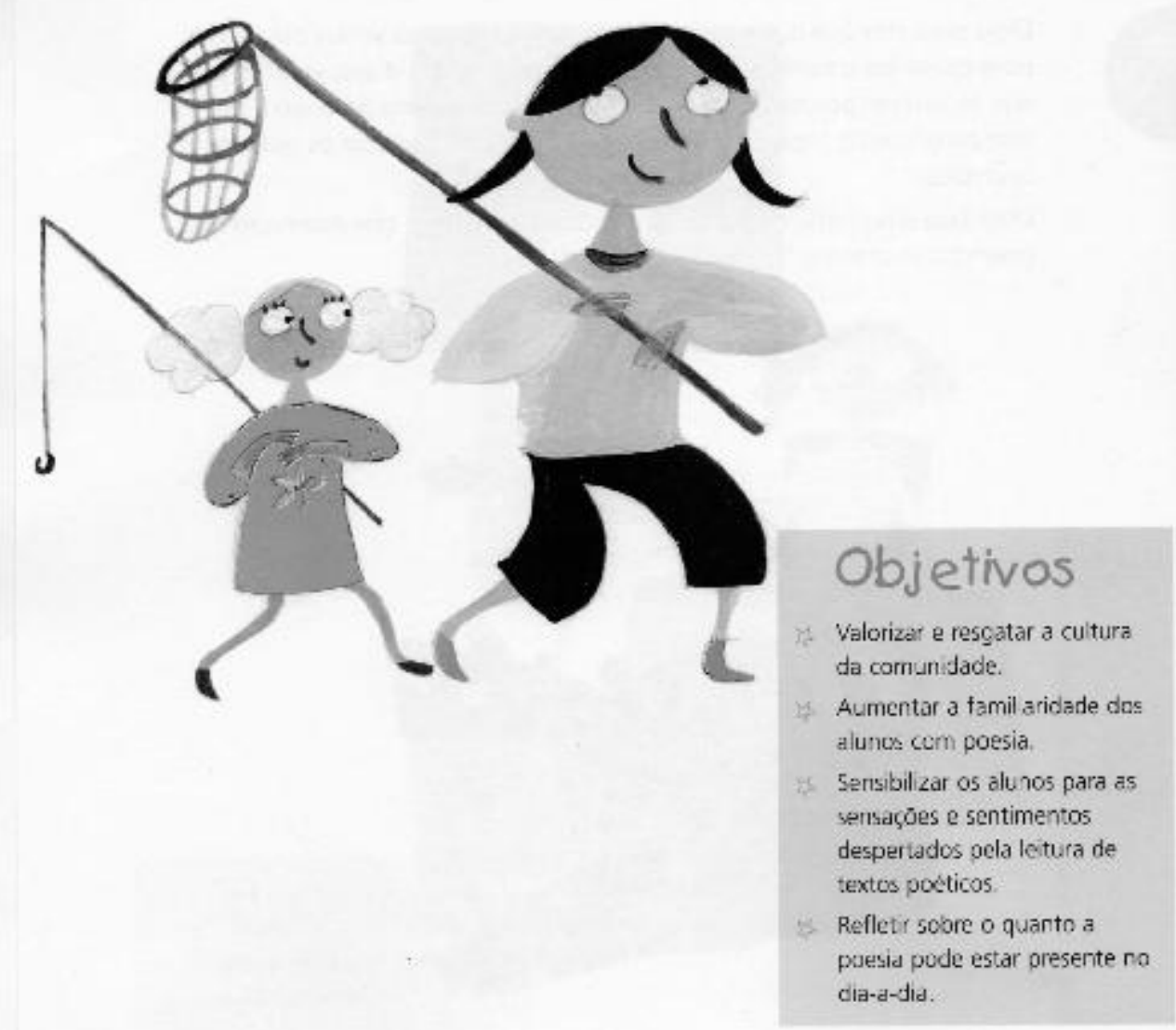




\section{Conversa com o professor}

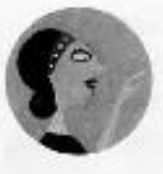

Nesta oficina vocé vai ler para seus alunos o texto adaptado do livro $O$ catodor de pensamentos e propor que se tornem "catadores de poemas", pesquisando os poemas conhecidos pela comunidade em que estāo inseridos.

Essa atividade depende da reclidade de cada um: 05 alunos podem sair pela cidade, bairro, rua da escola (quando isso for possivel), e entrevistar moradores. Podem fazer a pesquisa na própria escola, com professores, funcionários e colegas mais velhos. Podem também, como tarefa de casa, entrevistar pais, avos, vizinhos e parentes. Se na cidade morar algum poeta, ele pode ser entrevistado, ir à escola conversar com os alunos, ou o grupo pode escrever uma carta pedindo-lhe que envie um poema.

Você pode propor todas essas etapas ou algumas delos - o importante é que você, professor, ajude os alunos no planejamento e no organizaçāo da pesquisa.

\section{Atividades}

Leia para o grupo o texto adaptado do livro O cotador de pensomentos. disponivel na página 20.

Converse sobre a história com os aluno5. $O$ que sentiram ao ouvir a historia? Podemos dizer que é uma história poética? Por quê? (A) preocupação central aqui nāo é com a interpretação formal, objetiva do texto, mas ajudar as alunos a resgatarem as sensaçōes e sentimentos que o texto evoca.)

y Assim como o 5r. Antônio catava pensamentos, proponha a seus alunos que se transfomem em "catadores de poemas".

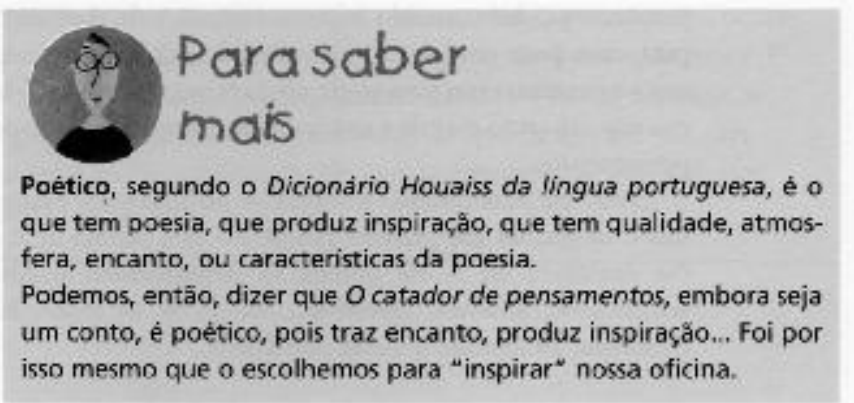


17. Organize e planeje com os alunos a forma que irāo adotar para "catar poemas", ou seja, recolher as poesias que a comunidade conhece.

3. A proposta é entrevistar uma ou mais pessoos, perguntanco o seguinte: Você gosta de poesia? Sabe o nome de algum poeta? Você conhece algum poema? Se a pessoa souber de algum, peça a ela que o recite e escreva seus versos e estrofes. Se o entrevistado nūu suuber nenhum poema de cor, peça c ele que copie um poemo de um livro ou empreste-lhe um livro de poesia.

* No final, proponha que foçam uma seleçõo das poesicos "catadas" para afixar no mural.

\section{O catador de pensamentos}

Monika Fethe ilustrodur Antori Berotynski

Vou concar a vocós uma história de que goseo muito. É a história do Sr. Anrônio, um homern velho, que rem um andar arrascado, nunca rem pressa, usa um casaco gasto c surrado e um boné desbotado. Tudu dia bem cedo ele sai pela cidado onde mora e percorte todas as ruas, becos c recintos. Ele carrega sempre uma mochila $t$ anda prestando muira arcnçăo.

Vocks sabem por que ele percorre toda a cidade muito atenro? - E. pata ouvir us pensamentos. - Isso mesmo, o $\mathrm{S}_{\text {r. }}$ Antỏnio consegue uuvir us pensamentos, mesmo auravés de parodes bem grossas. Isso te muito imporrante para ele, puis seu oficio é justamente o de Catador de Pensamentos.

Pensamentus de todus os tipos: alegres, tristes, inceligentes, bohos, bonitos, feios, compridos, curros c até mesmo baruthentos e silenciossos. Todos os pensamentos sáo importantes para u Sr. António, e ele sempre se pergunta admirado comn os pensamentos podem ser tāo diferentes entre si. Depois de petcorrer a cidade cacando os pensamentos, o Sr. António volta para casa para completar seu trabalho. Após comer alguma coisa e descansar um pouco, cle vai para seu quarto de trabalho, estende um pano grande c macio, abre sua mochila e despeja os pensamentos.

Entĩo ele desembaraş e separa os pensamentos cmaranhados e os guarda $\mathrm{cm}$ grandes prateleiras por ordem alfabécica. $\mathrm{Na}$ prareleira do $\mathrm{A}$ cle guarda os pensamentos acanhados, amalucados, amivcis, agressives. $\mathrm{Na}$ do $\mathrm{B}$, os belos, bohos, bondosos, brilhantes, e assim por diante. 


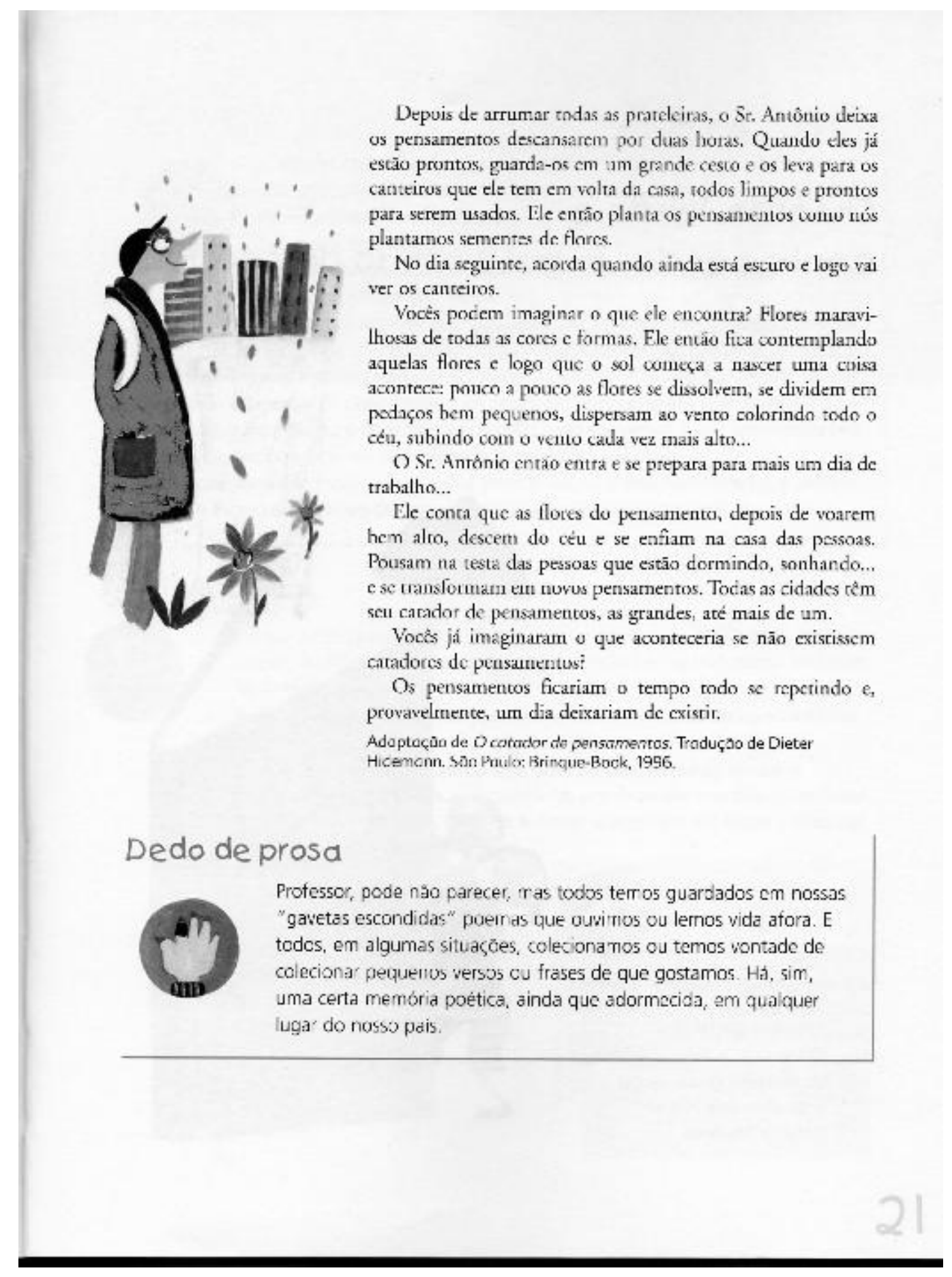




\section{Oficina 5}

Ouvindo, lendoe

conhecendo um pouco mais de poesia

\section{Objetivos}

44. Anpliar o resertćrio de poesia.

Familiarizar o grupo com poemas consagrados da literatura urasieira

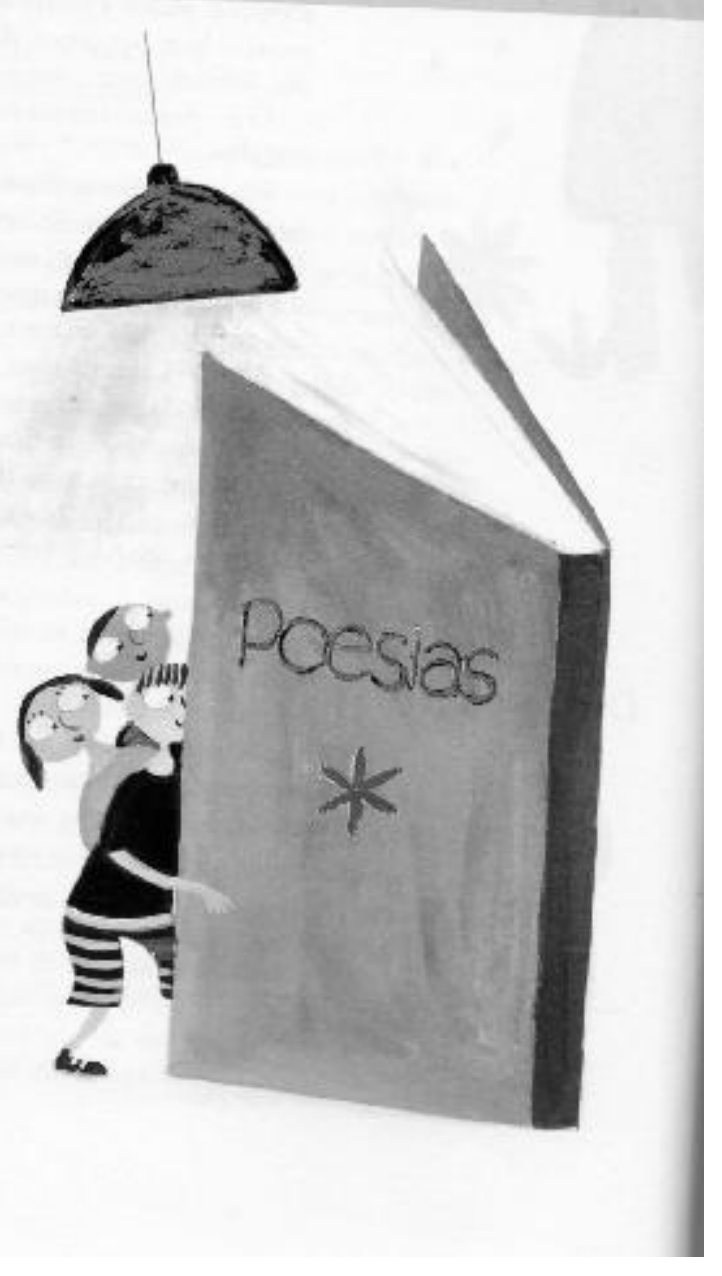




\section{Conversa com o professor}

Com certeza seus a unos descobriram muitos poemas. É importante, contudo, ampliar o repertório, e, para isso, "catamos" alguns para você levar para a sala de aula.

Selecionamos alguns para esta oficina (ver "Textos indicados", no final deste fascículo). Você pode também ampliar essa seleção. incluíndo seus poemas preferidos. Como já foi mencionado na introduçào deste fasciculo, os livros de poesia do Programa Literatura em minho casa têm poemas de alguns dos maiores poetas da língua portuguesa. Recomendamos que você tombêm os utilize nesta e nas próximas oficinas.

Uma idéia interessante pora motivar as crianças a trabalharem com poesia ê promover um sarou. Sarau é uma reuniāo festiva para conversar, ouvir apresentoçoes de música, trechos de livros ou, camo ê o nosso caso, poemas.

Você pode também trazer convidados para o sarau, como funcionários e professores da escola ou pessous da comunidade que conheçam e gostem de poesia.

\section{Atividades}

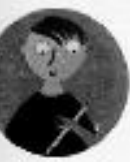

5. Divida a classe em grupos de três ou quatro alunos, distribua os livros de poesia do Programa Literatura em minha casa e/ou os poemas reunidos no final deste fasciculo.

1. Proponha aos seus alunos que pensem em uma forma de apresentá-los no sarou.

4. Organize junto com alunos a sala para o sarau. Pode-se mudar a disposiçāo das carteiras, colocando-as, por exemplo, em circulo, ou usar outro espaço da escola. Pode-se enfeitor o espaço e até mesmo oferecer um lanche para encerrar a reuniāo.

4. Escolha você tambèm um poema e aproveite o sarau para declama-lo aos seus alunos.

14. Peça aos alunos que escolhurm alguns poemas para serem transcritos e colocados no mural.

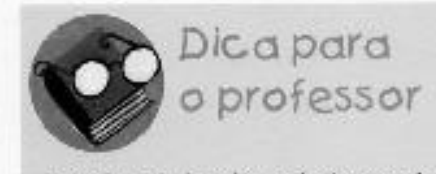

Lanche: $O$ lanche coletivo pode ser realizado com a colaboraçăo dos pais, com doaçōes de comerciantes da cidade ou com os alunos trazendo um bolo, frutas tipicas da regiăo etc. 


\section{Para saber mais}

Selecionamos alguns poemas (reunidos nas páginas finais deste fasciculo) nos quais os autores falam sobre o lugar onde vivem ou viveram.

Vamos ver como esses poetas deixam de lado o lugar-comum para fazer aquilo a que todo poeta se propóe: pegar na măo dos leitores e encantá-los, trazendo inspiraçăo e despertando emoçōes.

- "Sertăo" - Ascenso Ferreira (PE)

- "Coisas do reino da minha cidade" - Cora Coralina (GO)

- "Mar azul" - Ferreira Gullar (MA)

- "Episódio sinistro de Virgulino Ferreira" - Carlos Pena Filho (PE)

- "Infáncia" - Carlos Drummond de Andrade (MG)

- "Na rua Mário de Andrade" - Manoel de Barros (MT)

- "Cançāo do exilio" - Gonçalves Dias (MA)

- "Na minha terra" - Alvares de Azevedo (SP)

- "Pátria minha" - Vinicius de Moraes (RJ) 


\section{Oficina 6}

\section{Brincando com as emoçós e as palavras}

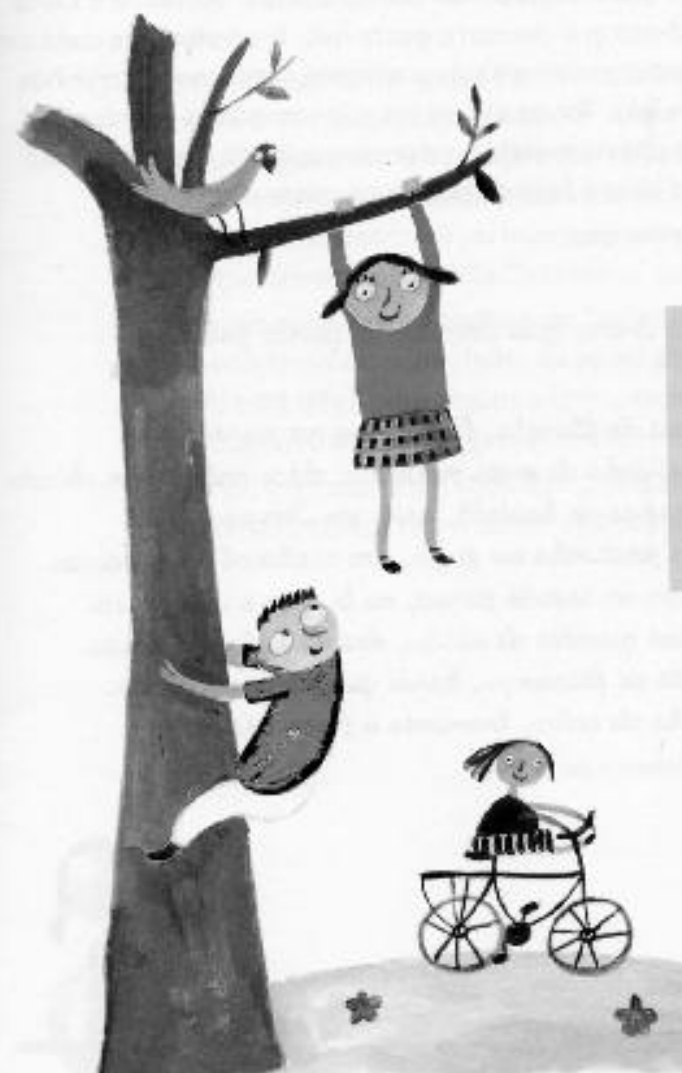

Objetivos

3. Sersibilizar o aluno para

percuber e identificar numas e poemas.

Possib litar a triacso de rimas. 


\section{Conversacom o professor}

Os poetas gostam muito de jogar com as palavras e conhecem diferentes maneiras de fazê-lo. Otóvio Roth, no seu livro Duas dúzias de coisinhias à-toa que deixam a gente feliz, brinca com as emoçōes e com a rima das palavras. Foi por isso que o escolhemos para esta oficina.

\section{Atividades}

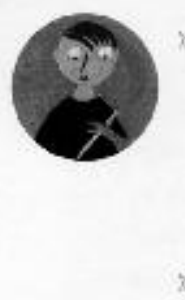

Conte para os alunos que iroo trabalhar com um texto cujo name e Dusas dúzias de coisinhos d-toa que deixam a gente feliz. Proponha que cada um deles pense e conte para os demais coisas simples, cotidianas ("coisinhas a-toa") que o deixem feliz. Talvez alguns mencionem coisas grandes, importantes, como a paz no mundo ou a preservação do meio ambiente. Mas insista em que a idêia é falar de pequenas coisas do dia-a-dia.

z. Leia, entåo, o texto para eles.

Duas dizias de caisinhas à-taa que deixam a gente feliz Otávio Roth

Passarinha na janeta, pijama de flanela, Arigadeira na panela. Gata andanda na telhada, cheirinha de mata molhada, disca antiga sem chicida. Pãa quentinha de manhä, drapes de hartelä, grita da Jargan.

Jirar a sarte na assa, jagar pedrinha na paga, um cachecal na pescapa. Papagaia que conversa, pisar em tapete persa, en te ama e viceversa. Vaga-lume acesa na mäa, dias quentes de veräa, descer pela carrimāa. Almaga de daminga, revaada de flaminga, herái que fuma cachimba. Anäaginha de jardim, lacinha de cetim, terminar a liura assim.

Duas dizios de coisinhas di-tou que deixam a gente foliz. São Paulo: Ática, 1994. 
6. Converse com os alunos sobre o que acharam do texto. Que sensaçoes e sentimentos ele desperta?

41. Discuta a sonoridade do texto: vocês sabem como se chama a repetiçâo de sons no final de polavros? Que sons se repetem no poema? Quais são as polovros que rimam?

7. Transcreva o texto na lousa e assinale as rimas junto com os a unos.

4. Peça, a seguir, a cada um deles que desenthe uma coisinha à-toa que o deixa feliz.

4. Lance, entōo, o seguinte desafio: vamos escrever o nosso "duas dúzias de coisinhas à-toa que nos deixam felizes"? (Pode ser também quatro dúzias, duos dúzias e meia, dependendo do número de alunos da classe.)

7. Para começar, forme grupos de três culunos. Peça a cada um deles que procure dois colegas cuja "coisinha" que o deixa feliz rime com a dele. $\mathrm{Se}$ noo conseguirem a rima, sugira que se juntem com dois colegas e que, juntos, tentem modificar a ordem das palavras, procurar urn sinónimo, ou até mesmo descobrir ou inventar novos gostos... O importante é que cada trio consiga obter três "coisinhas" que rimem.

4. Cada trio apresentará então suas "coisinhas". Você pode transcrever as rimas na lousa ou numa folha de papel grande. Caso você perceba que a tarefa está difícil para alguns alunos, escreva as palavras na louso, construindo junto com $\mathrm{a}$ grupo as rimas.

13 Ao final, conte quantas coisinhas à-tou deixam a classe feliz e peça que suciram um título para o texto final do exercicio.

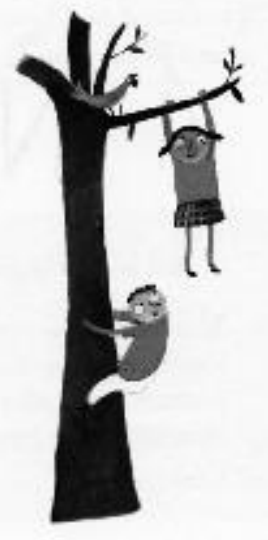




\section{Oficina 7}

Brinc ando um pouco mais com as palavras:rimas, repetiçôes e aliteraçôes
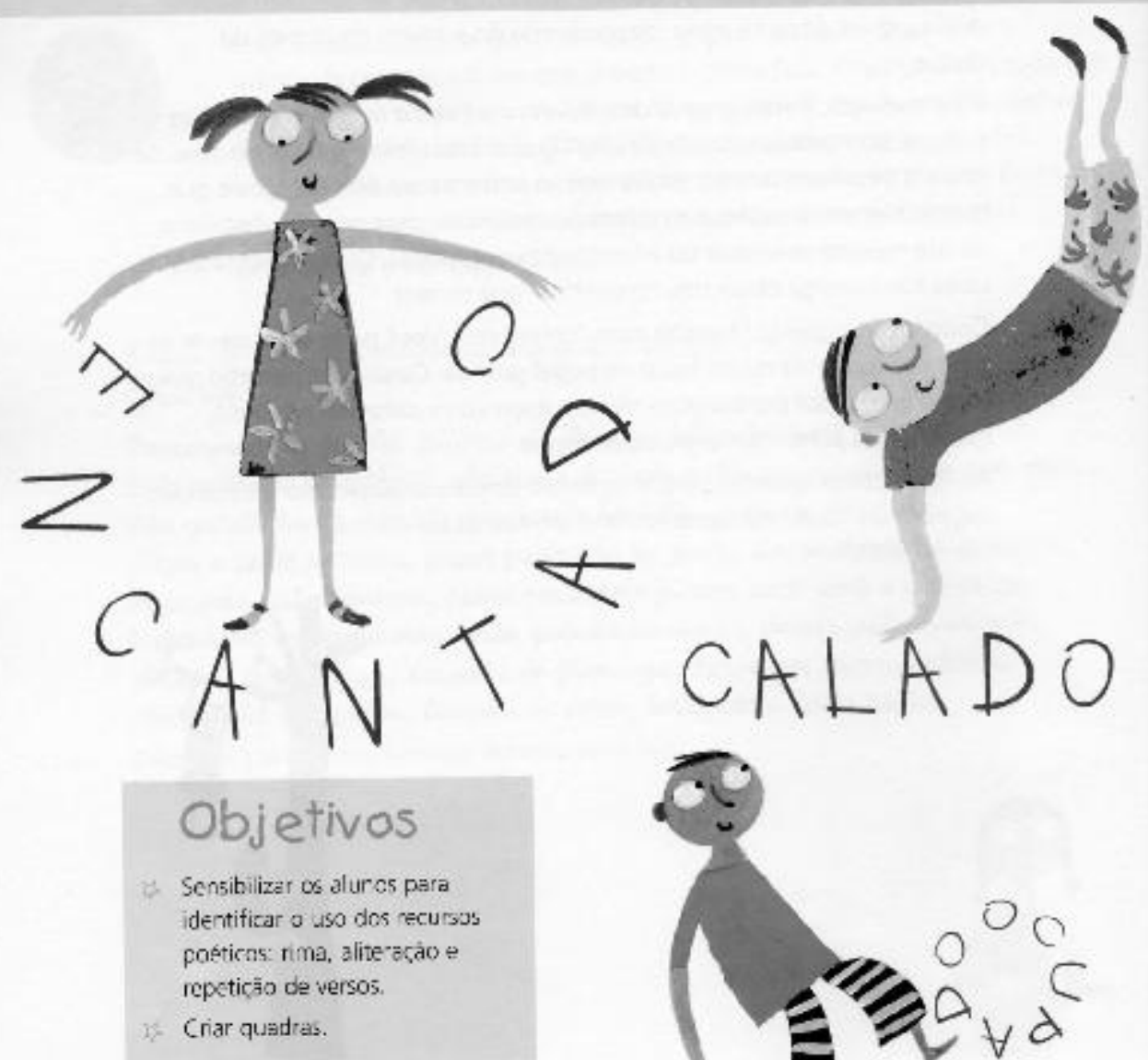

CALADO

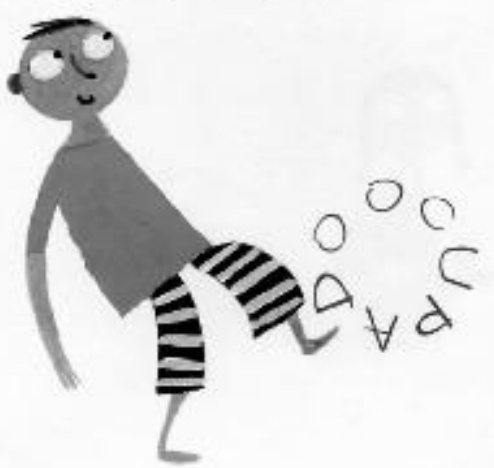




\section{Conversacom o professor}

Para encantar os leitores, transmitir suas idéias, experiências e emoçoes de forma origincl, os poetas se utilizom de recursos poéticos, como, por exemplo, rimas, aliterações, metóforas, repetiçōes de polavros, estruturaçāo visual, entre outros.

A aprendizagem desses recursos faz que 0 aluno se esquive de temas, palavras e versos estereotipodos que, de tão repetidos, já estao banalizados e, mais importante, ajuda-o a produzir poemas mais originais. Nas próximus oficinas trabalharemos com alguns desses recursos com o objetivo de dotar os alunos de instrumento5 que os capacitem a produzir poemas e poesias que enconlem os leitores.

\section{Atividades}

Pergunte: quem conhece umo quadra? Vale dar dicas para eles.

Transcreva na lousa estos duas quadras:

Näa sei se vá aus se fique

Näa sei se fique ou se vá

Ficanda aqui nāa vau lá

$\varepsilon$ ainda perca a meu pique.

Sivio Romero. Contos popuiores do brosit Sáo Poulo: lose Olympio, 1954.

Ô seu maga inteligente

3aça a fauar de diger

En cima daquele marra

Quanta capim pade ter?

Ricarda Azevecio. Armozém do foiclore.

Son Paulo: Atima, Jono

3 Peça para a closse que observe se esses versos rimam. Quais palavros rimam? Veja se a turma consegue descobrir a diferença entre os dois esquemas de rima.

4. Escreva na lousa a quadra transcrita na página seguinte e peça aos alunos que cescubram uma palovra que rime com "melado* e faça sentido.

Na primeira quadra, recolhida por Silvio Romero, o primeiro verso rima com o quar to (fique e pique) e o segundo, com o terceiro (và e lá). lá Ricardo Azevedo rima o segundo verso com o quarto (dizer e ter). 
Lá na funda da quintal

Jem um tacha de melada

Quem nãa sabe cantas wersa É methor ficar...

Ricardo Azevedo. Armazén do faicione. Sóo Paula: Ática, 2000.

Observaçāo: a palavra que o autor usou é "calado", porém seus alunos podem dar outras sugestōes. $O$ importante é construir uma rimae nāo perder o sentido do verso.

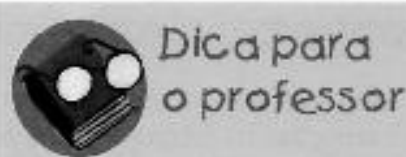

Quadra é uma estrofe composta por quatro versos. Vários poemas incluem quadras entre suas estrofes.

As vezes, uma quadra é um poema, como os dois textos da página anterior. Como se pode ver, os versos de uma quadra podem rimar de diferentes formas.

7. Divida a classe em trios e peça para cada grupo que crie uma quadra.

Muitas vezes as alunos ficam tão preocupados em encontrar polavras que rimam que se esquecem de verificar se o verso construído transmite ao leitor uma idéia, sentimentos ou sensação. Você pode e deve conversar com eles a esse respeito. Leia e analise junto com eles os poemos do Apêndice e mostre como o5 poetas, ao usarem o recurso da rima, sāo cuidadosos na escolha das palavras. Os versos e as estrofes nāo sāo construidos apenas com palavros que rimam entre si; eles devem articular-se como um canjunto que produz um sentido.

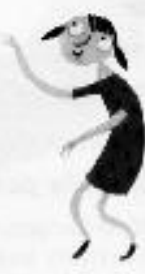

4. Poetas clássicos, como Olavo Bilac, tembém usam quadras para compor poemas. Transcreva na lousa ou tire cópios do poema de Bilac "A boneca" (pág. 31), composto em quadras com um esquema de rimas fixo: o primeiro verso rima com o terceiro e o segundo, com o quorto.

\$. Divida a classe em pequenos grupos e peça que descubram as palovras que rimam e esquema usado por Biloc. 
A baneca

Olavo Bilac

Deixanda a bala e a peteca,

Cam que inda há pouca Erincauam,

Par causa de uma boneca,

Duas meninas Brigavam.

Dizia a primeira: " $\dot{\varepsilon}$ minha."

- "É minha!" a cutra gritava;

E nenhuma se cantinha,

Nem a baneca largaua.

Quem mais sofria (coitada!)

Era a baneca. Lá tintia

Jada a raupa estraçathada,

E amarratada a carinfa.

Janta puxauam par ela,

Que a pabre rasgau-se aa meia,

Perdenda a estapa amareta

Que the farmava a recheia.

$\varepsilon$, aa fim de tanta fadiga,

Voltanda a bala e a peteca,

Ambas, par causa da briga,

Ficaram sem a baneca...

Polowras uje encuniturnerita 5ũo Poulo: Moderna, 2001. v.1. (Programa Literatura em minha cosca)

2. Mostre também para os alunos que existem outras formas de brincar com as letras. Uma das mais interessantes è praticada por Cruz e Souza no poema "Violỏes que choram" (pág. 32). 
Vialöes que charam

Cruz e Souzo

Vages veladas, veludasas uages, Valizian das vialöes, nazes veladas, Vagam nas veltras wártices velages Das ventas, viucas, väs, vulcanizadas.

Oaras compietas. Ris de janziro: Novo Aguilar, 1997.

1 Desafie os alunos perguntando: por que esse poema pode ser considerodo sonoro e musical? Qual ê o som que se repete ao longo dele?

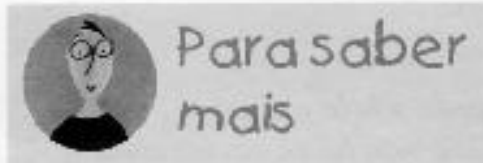

Nesse poema, Cruz e Souza usa um recurso chamado aliteraçāo, ou seja, a repetiçăo de fonemas no inicio, meio ou fim de palavras próximas, ou distantes, em um ou mais versos.

O livro Meus primeiros versos, do Programa Literatura em minha casa, edição de 2002, contém vários poemas de Cecilia Meireles em que ela usa a aliteraçăo. Vocé pode incentivar os alunos a ler e descobrir os sons que se repetem.

4. Outra forma de brincar com as palavras é repeti-los ao longo do poema. As vezes, os poetas repetem até mesmo versos inteiros para reforçar ou realçar umo idéia.

* Leia para os alunos o poema "Cançoo do exilio". de Gonçalves Dias (transcrito no Apêndice deste fascículo), no qual ele repete várias vezes o verso "Onde cantc o Sabiä". Pergunte aos alunos: qual verso o poeta repetiu? Essa repetiçāo causa qual efeito em quem lह ou ouve o poema? 


\section{Oficina 8}

\section{Conhecendo poesia popular}

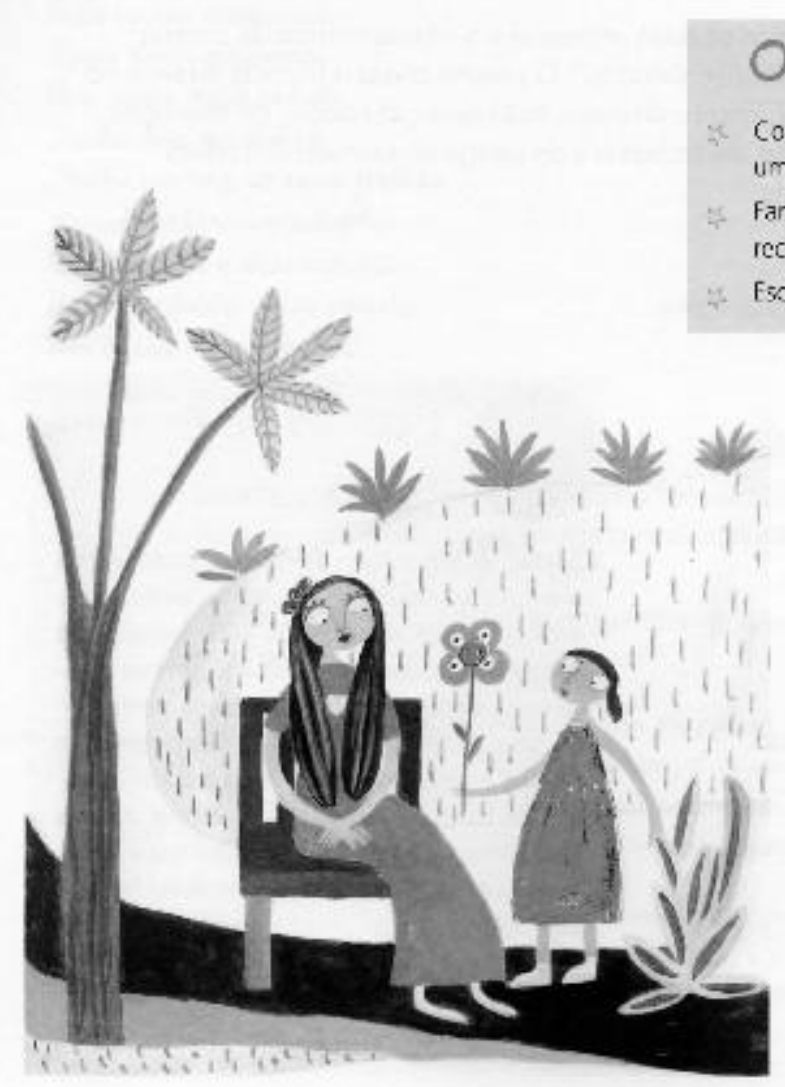

Objetivos

Conhecer poesia de corde $\mathrm{C}$ um poeta pcoular.

Familianzar-se com mais un recurso postico: ac'éstico

Escrever acróst cos. 


\section{Conversa com o professor}

Além de poetas clássicos, como Olavo Bilac, Cecilia Meireles e Gonçalves Dias, apresentados na oficina anterior, existem no Brasil os chamados "poetas populares" que compōem versos que encantam e emocionam o leitor, como o cordel. Convide o5 alunos a ler um trecho de um dos nossos maiores poetas de cordel, Patativa do Assaré.

Pergunte: Quem conhece poesia de cardel? Quando e onde ouviram ou leram cordel? Quais autores de cordel conhecem?

\section{Atividades}

Leia para os alunos as duas primeiras e 0 último estrofe do poemo "Emigraçāo e as conseqüéncias". O poema conto a história da seca no Nordeste, do sofrimento do povo, das injustiças socicis, da migraçäo para o sul, da luta, do trabalho e do perigo da entradu dos fithos na marginalidade.

Enigraçãa e as conseqüências Pazat vo do Assaré

Nesse estila papular Nos meus singelas versinhos, $O$ leitar vai encontrar Em vez de rasas espinfias Na minha penasa lida Canhega da mar da vida As temerasas tarmentas. Eu sau a paeta da raga Jenha mäa calasa e grassa Da caba das ferramentas. Par farga da natureza

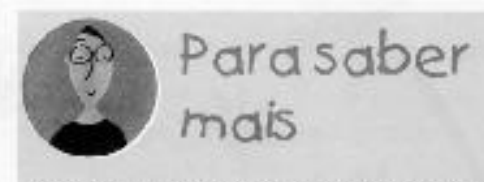

Cordel é um estilo de poesia popular da tradiçăo nordestina. Cantada ou declamada, está presente na maioria dos festejos da comunidade sertaneja: feiras, festas religiosas, comicios etc. É uma poesia narrativa, ou seja, conta uma história. Geralmente, o tema è o cotidiano, a denúncia dos sofrimentos do povo, a exaltaçăo de heróis e tipos populares, as lendas ou tradiç̧es nativas. A denominaçăo "cordel" deve-se ao fato de que os livretos costumam ser pendurados em fios de algodăo, os cordéis, nos pontos de venda. 
Sou poeta nardestina

Parém sá canta a pabreza

Da meu munda pequenina

Eu nãa sei cantar as glárias

Nem também canta as vitarias

Da herái cam seu trasãa

Nem a mar cam duas águas.

Yá sei contar minhas mágaas.

$\mathcal{E}$ as mágaas de meu irmäa.

Com certeza, o conhecimento que as crianças tem de cordel vai variar de acordo corn a regỉ̌o em que vivem. Vocè deve adaptar esta oficina à realidade delas.

Meu bam gesus Nagarena.

Pela vassa majestade

Fagei cada pequena

Que vaga pela cidade

Jenha baa proteçãa.

Jenha em vez de uma prisãa

Aquele inferna medonha

Que revalta e descansala

Bam canfarta e ba escala

Unt lánir e a caderna.

Uma vaz do Nordeste, Sao Paulo; I ledra, 2000.

(Bibliulew ce Cordel)

Mostre aos alunos que todo poemo tem um temo, isto é, o principal assunto au mensagem. Discuta com cles: qual o tema desse poema? Do que fala Patativa do Assaré?

- Em seguida, leia para eles os seguintes versos e pergunte o que cada um entendeu deles.

\author{
Nesse estila papular \\ Nas meus singelas wersinhas, \\ O leitar vai encontrar \\ En vez de rasas espinhas
}

4 Nesses versos, Patativa anuncia o estilo de poesia que faz-popular - e conto para o leitor que em scus versos nåo vai encontrar apenas "rosas", ou seja, coisas belas, mas também "espinhos": a tristeza e os problemas da comunidade onde vive. 
Retome com os alunos a conversa que tiveram na oficina 2, sobre o que os poetas exprimem em seus poemos, reafirmando que belos versos como os de Patativo podem folar sobre snfrimento, dificuldades... Afinal, a poesia traduz a forma como o poeta vê umo situaçõo, um ucontecimento.

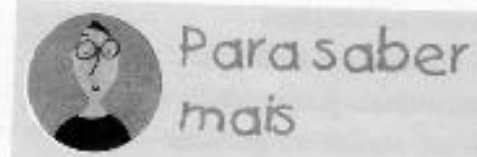

Estilo: maneira de expressar-se de um escritor ou de um grupo literário. Tema: principal assunto ou mensagem de um poema.

Roseana Murray. Pecueno glossário de poe sia. In: A bailarino e outros poemas. Säo Paulo: FTD, 2001 v, 1.

4. Transcreva no lousa mais

alguns versos de Patotiva do Assaré (nào se esqueço de resscltor a primcira letru de cadu verso) e lance um desafio: quem descobre algo diferente nesse poema?

77. Conte para seus alunos que Patativa do Assaré. para compor esses versos, usa, além do recurso da rima, o acróstico.

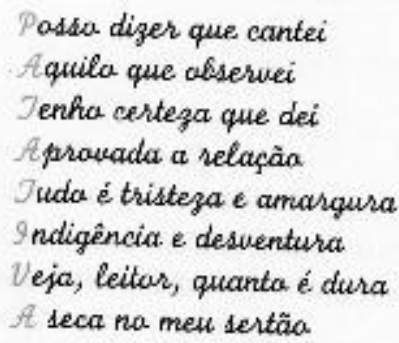

Futativa dos Assaré, ASC do Nordeste Rucgelado. Sâo Paulr Hedra, 2001 (Bibliotecus de Corde)

Agora, sugira que coda aluno crie un acróstico como próprio nome, usando suos características, jeito de ser, gostos etc. para compor os versos.

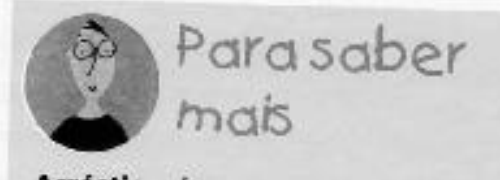

Acróstico é uma composição poética em que as letras iniciais dos versos formam verticalmente uma palavra ou frase, muitas vezes um nome próprio. Os poetas populares usam esse recurso como forma de identificar suas produçōes, assegurar a autoria de seus versos que sáo divulgados em publicaçöes expostas em corcéis, em espaşos públicos, como feiras. 
Escreva na lousa as trases a seguir e peça aos alunos que as completem.

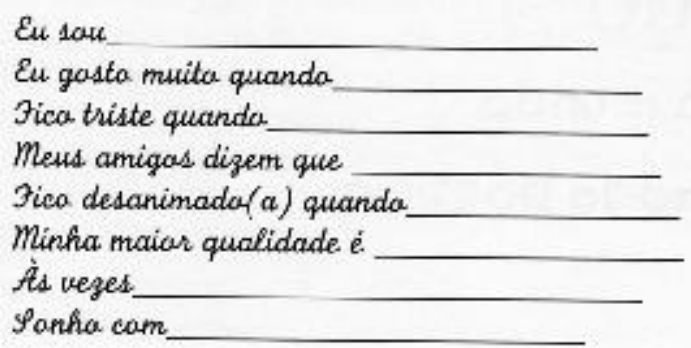

Peça paro os alunos que comecem escrevendo o próprio nome, verticalmente, no papel. Depois incentive-os a encontrar palavros relacionadas à maneira de ser de cada um, às suas características físicas - verdadeiras ou desejadas -, que comecem com cada uma das letras do nome, e anote-as co lado. Ajude-os na esco ha de uma ou mais polavras para cada letra. Agora, é só fazer as versos do acróstico e expor para o grupo.

- Escoho alguns acrósticos para colocar no murcl.

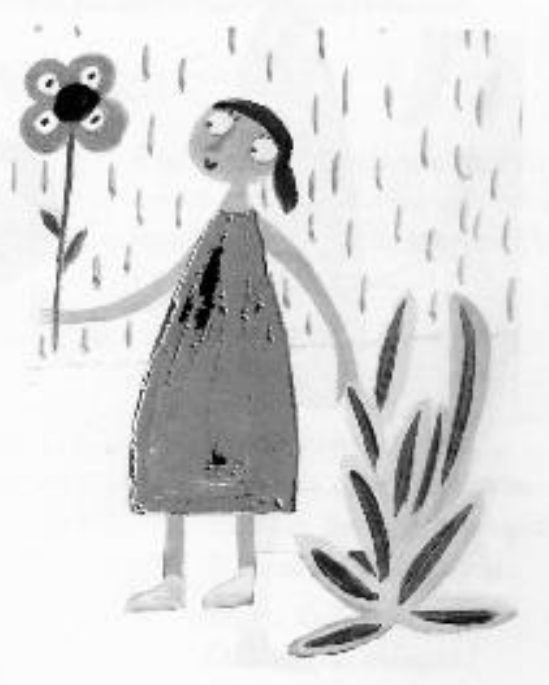

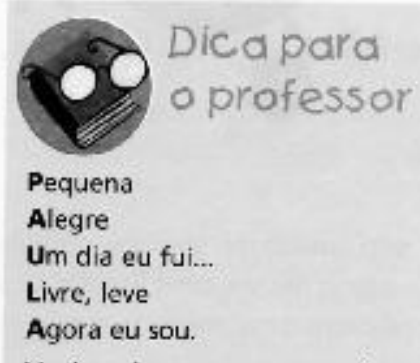

Vocé pode usar esse exemplo para explicar para os alunos o que é acróstico. 


\section{Oficina 9}

Vendo o mundo

de um modo poético

\section{Objetivos}

Sersibi izar o aluno para a identificasăo de comparacçes, imagens, metśforas.

8. incentivar $Q$ aluno a produzir lextos com os recurses acima

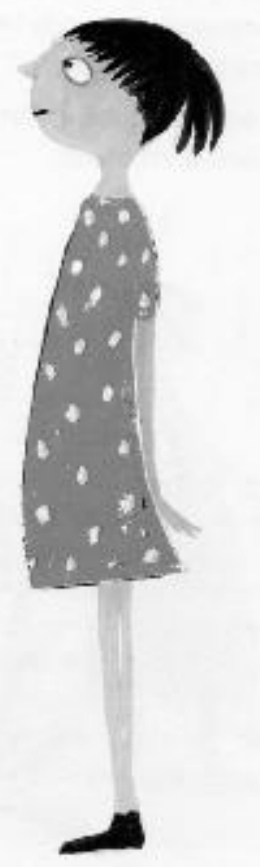




\section{Conversacom o professor}

Como vimos, o essencial em poesia é a maneira de olhar o mundo e um jeito especial de registrar esse olhar. Ana Maria Machado, na nota de abertura do livro Cinco estrelas, do Programa Literatura em minha casa, 2002, ajuda-nos a compreender melhur esse aspecto: "[...] Nõo ế só a forma que importa, mas principaimente a maneira de ver as coisos. Um modo diferente do comum. Como se o mundo estivesse sendo visto pelo primeiro vez de um modo novo".

Deve ser por isso que Fernando Pessoa, poeta portuques e um dos maiores de nosso lingua, escreveu os seguintes versos:

\section{Nãa Gasta abrir a janela}

Para ver as campas e rias.

Nãa é Gaslante nũa ser cega.

Para ver as áruares e as flares.

Pcemas inconjuntos. In: Fuçäes do intserlídic, Sào Poulo Companhis das Letros, 2003. p. 237

Reflita sobre esses versos. Se achar conveniente, escreva-os na lousa e discuta com a classe possíveis significados para eles.

\section{Atividades}

Explique aos alunos que vocế vai ler alguns versos de um poema que talvez conheçam: a letra de uma cançāo infantil feita por um poeta famoso - Vinicius de Moraes. (Se seus alunos conhecerem a melodia, podem cantar a música.)

$$
\begin{aligned}
& \text { O leãa. } \\
& \text { Vinicius de Morces }
\end{aligned}
$$

Leña!' Leãa!' Leãa!

Ruginda cama a travia

Deu um pula, e era uma vez

Um cabritinha mantês.

Leãa! Leãa! Leãa!

Es a rei da eriaçäa! 
Tha gaela é uma farnatha

Jes salto, uma labareda.

Jua garra, uma navalfa

Cartanda a presa na queda.

[...]

A arco de Noż 2, od. Soo Paulu: Companhia des Letrinhos, 2002. v.1 p. 22.

(Programo Literatura em minha caso)

1. Pergunte aos alunos: por que no verso "rugindo como o trovão" o poto compara o rugido do leùo a um trovào?

7. Discuta o significado de força, de poder e de altura de som que a comparaçoo rugido/trovoo traz para o poema.

4 Mostre agoro a eles que, em outros momentos do poema, o autor aproxima o leảo - partes de seu corpo, açōes que ele protica - de elementos que reforçam o sentido de força e poder que ele quer atribuir co lē̄o.

Exemplifique com os versos:

Jua gaela é uma farnalka

Jeu satta, una Eabareda

Jua garra, uma navatha

Cartanda a presa na queda.

1. Esse tipo de linguagen, que permite uma identificaçāo entre coisas aparentemente independentes umas das outras, chuma-se metafora.

17. Peça aos alunos que procurem no mural outros versos que apresentem comporaçōes ou metóforas.

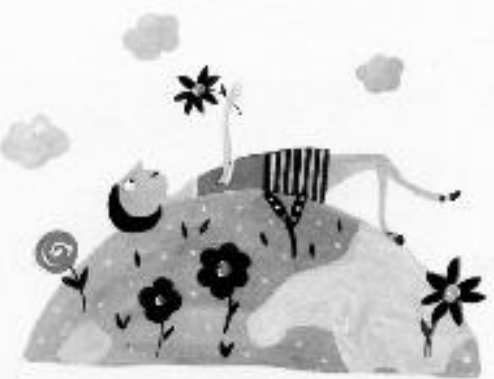

Ao ver o mundo de um modo poético, os poetas podem tazer comparaçōes e, ao fazê-los, muitas vezes usam uma linguagem econômico e direta, criando uma metafora. Ana Maria Machado tem exemplos que ilustram bem esse processo. Vale mais uma vez conferir seu texto na introduçóo do livro Cinco estrelas, Programa Literatura em minha casa, 2002. 
7. Pergunte aos alunos se ho animais na regiāo onde moram ou qual o animal preferido do grupo. Qucis as características desse animal? Relacione-as no lousu.

2 Combuse nessas características, produzo junto com a clusse textos com comparaçōes e metoforas.

Faça, entảo, aos seus alunos as seguintes propostas: Pensem no

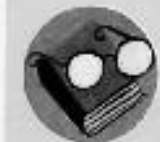

Para fazer comparaçōes, podemos usar varias expressỏes.

Exemplo: é pcquerio como . seu pä́lo parece,., sua car lembra.. Sua garra täro.. Guanto.

Apontar essas possibilidades para os alunos pode ajuda-los a fazer comparaçces ou produzir poemas. lugar onde vivem, em umc praça, úrvore ou recanto que apreciem. Qual a impressão que esse lugar transmite para voc\&s? Façam comparaçōes, criem imagenıs. Registrem em seu caderno.

* Agora vamos fazer o contrário: pensar em coisas de que vocês nāo gostom, que os preocupam, deixam-nos tristes. Qu cis sủu us impressỏes? Novamente, façam comparaçōes, criem imagens, Registrem-nas em seu caderno. Quem quer mostrar para o resto do grupo? 


\section{Oficina 10}

\section{Analis ando diferentes} olhares sobre o mesmo tema

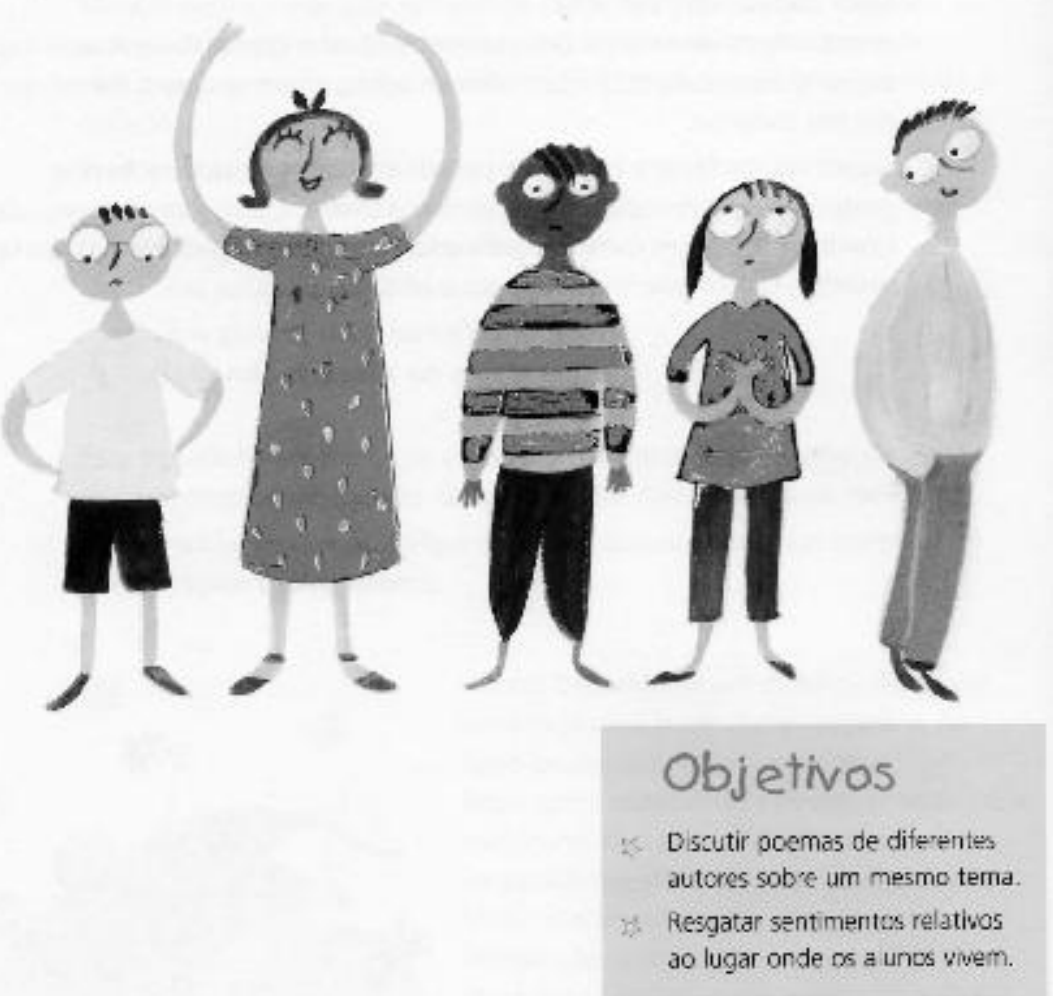




\section{Conversacomo professor}

Para esta oficina, escolhemos três poemas:

- "Mapa na mão", de Nicolas Behr;

- "Milagre no Corcovado", de Ângela Leite de Souza.

- "Cidadezinha", de Mário Quintana;

Com base na leitura desses poemas, oprofundaremos dois aspectos discutidos nas oficinas anteriores: tema e recursos poéticos. Na primeira etapa, vamos enfocar o tema dos poemas. O tema escolhido foi a lugar onde vive ou viveu o poeta por ser esse o tema do poema que os alunos vāo escrever no final das oficinas. Na segunda etopa, vamos constator que os poetas, apesar de falarem do mesmo tema, usam recursos poéticos diferentes. Mário Quintana usa o recurso da rima; Ảngela Leite de Souza, as comparaçōes e as metoforas; e Nicolus Behr, repetiçōes, listas de palavros conhecidas e abreviaçōes.

\section{Atividades}

$1^{10}$ etapo

Divida a classe em grupos e entregue a cada um deles um dos três poemas. Se sua classe tiver muitos alunos, um mesmo poema pode ser distribuido a mais de um grupo. (Neste caso, faça algumas cópias.)

Peça a cada grupo que discuta o texto, observando se ele tem alguma relaça to com o lugar onde vivem. Com base nisso, devem pensar em uma forma de apresentú-lo para o resto do grupo. Os poemas podern ser declamados de várias moneiras, por exemplo, com gestos e movimentos, ou em formu de jogral. Incentive os alunos a procurar uma forma diferente de apresentá-los. O importante é que o ritmo e a entonaçao da declamaçāo "mexam" com os ouvintes.

Para apreciarmos realmente uma poesia, é preciso que, além de lê-la, possamos escutá-la; por isso é importante que o declamador prepare a leituro, cuidando do ritmo, das pausas $e$ da entonaçāo da vǒ.

7. Fin seguida, proponha uma discussüo: o que esses poemas tềm em comum? Lance um novo desafio: se esses poemas falam sobre o mesmo ossunto - olugar onde vive ou viveu o poeta -, por que têm títulos diferentes? Que contribuição o titulo de cado um deles dá para quem vaile-lo? 
$2^{i}$ etapa

7. Transcreva os poemas desta oficina em uma folha de papel grande ou na lousa. Peça aos ulunos que observem os poemas. $O$ que sc pode notar? Como coda um deles constrói musicalidade? Qualo recurso poético que cada um dos poetas usa para falar do lugar onde vive?

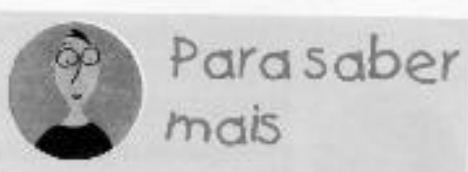

Muitas vezes o titulo de um poema, assim como o de um filme, é decisivo para desnertat na pessoa a vontade de lè-lo. Por isso os escritores escolhem com muito cuidado os titulos de suas obras.

4 Como já dissemos na oficina 2 , provoque seus alunos a pensar, trocar idéia5, fazer perguntas, tirar conclusōes, buscar informaçōes...

4. Use as informaçōes fornecidas pelo texto "Conversa com o professor" e pelos boxes. Finalize a atividade organizando as idéios discutidas pelo grupo.

\section{Mapa na mãa}

Nicolos Behr opud Y. Fujpamn, 1. B. Soyeg e Wadir Nader (orgs)

Mapa na mãa

alta na mapa

mäa na altha

wamas tentar encantrar a cidade

eu $\varphi$

tuQ

ele $s$

nós $y$

uás $Q$

eles $n$

Gacas eiras quadras

1enhared,

esta cidade

É uma aula de geametria

Veicu poética Soo Paulro: Vertente Editora, 1981 p. 57.

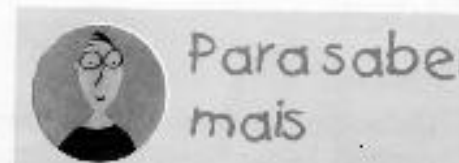

Observe que:

Nicolas Behr, em seu poema, faz alusbes ao mundo da Geografia e à estrutura urbana de Brasilia (cidade planejada, com ruas nomeardas com base nas superquadras dis postas ao longo do eixo que corta a cidade de norte a sul) para fazer o leitor "sentirse $^{\text {" nessa cidade. }}$

Ảngela Leite de Souza, no verso "fica pousado no algodäo-doce", registra a impressâo que tem da visăo do Cristo iluminado à noite, cercado pelas nuvens: a de um milagre, pois ele parece estar pousado em algodăo-doce. Isso ocorre tamhém com "vira mosquito", com que transmite a impressào de pequenez do ser humano diante de um monumento tåo grande. 
Milagre na Carcanado

Angelc Leite de Stuza

Jodas as noites.

De céu nublada

na Carcauda

Fas seu milagre a Redentar:

Fica pausada na algadãa-dace

Tluminada

Cama se fasse

De irapar

Mas todos satem.

Que bern de perta

Esse gesus

$\dot{\varepsilon}$ un gigante

De mais de mil

Ecem taneladas...

Suba de trem,

Vá pela estrada,

Quem cherga lí,

Aa pé da Crista, vira masquita.

$E$ altanda em valta

Para a cidade

De panta a panta marawilhasa

$A$ gente sente um arrepia:

O milagre é a prápria Ria!

Wiews Rics. Belo Horizonte; Formoto, 2002. pp. $19-20$.

\section{Cidadezinha}

Mưria Ouintana

Cidadeginha cheia de graça...

Jãa pequenina que até causa dá!

Cam seus furricas a pastar na praça..

Sua igrejinhra de uma tarre sá...

Nuwens que ventam, nusens e asas,

Räa param nunca nem um segurda...

E fica a tarre, sabre as velhas casas,

Fica cismanda cama é uasta a munda!...

Eu que de lange venha perdida,

Sem pausa fixa (a triste sina!)

Ah, quem me dera ter lá naseida!

Lá tada a vida pader marar!

Cidadeginha... Tâa pequenina

Que tada cabe num sá altar...

Liti imenta o mundo. 9. ed, Porto Alegre: Mercoudo Abets, 1991.

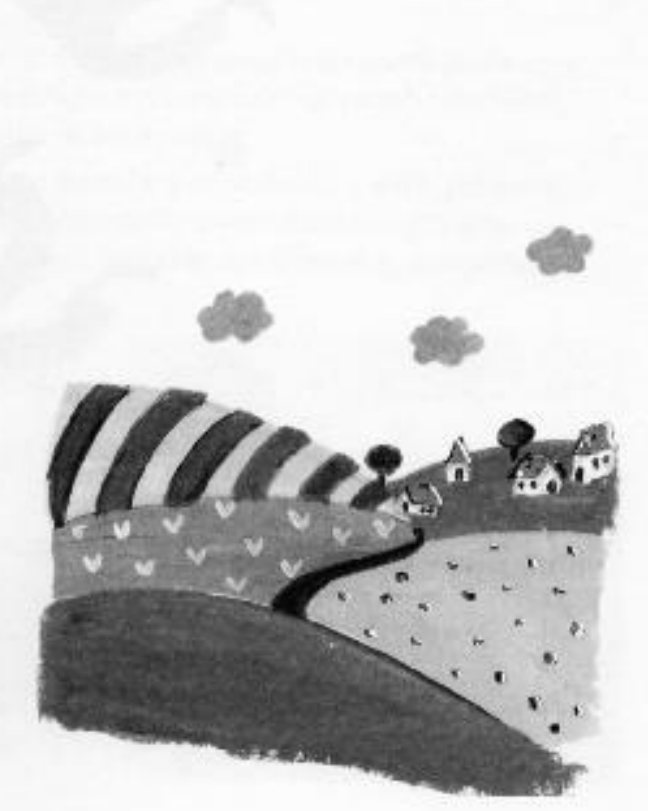




\section{Oficina II}

Reconhecendo emoções e sentimentos, tornando-se poeta

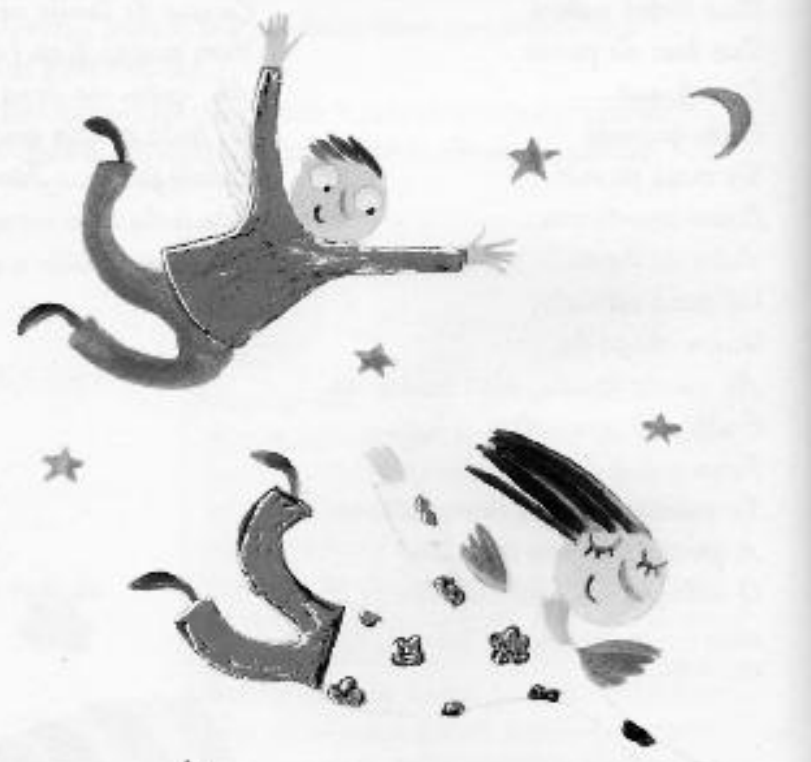

Objetivos

14. Poss hil tar ao alt.no perceber emocóes e reconhecer sertimentos.

Produzir um poema que

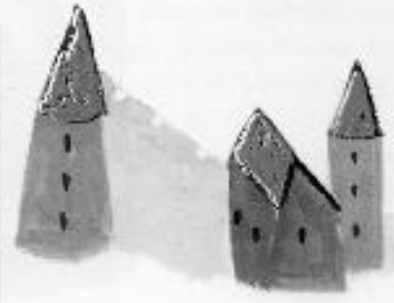




\section{Conversa com o professor}

Você nuão uchu quue seus alunos já podem criar um poemo em pequenos grupos? É isso que vacê vai propor a eles ao final desta oficina.

Antes, porém, vamos conversar um pouco sobre um aspecto que consideramos muito importante e fundamental para o educaçao de crianças e adolescentes,

É tarefa da escola promover o desenvolvimento do aluno, integrando as dimensóes cognitiva, afetiva e motora; porém, muitas vezes, na correria do dia-a-dia, esquecemos que nossos alunos sāo pessoas completas, com pensamentos e afetos. Estamos täo ocupados com a rotina que deixamos passar oportunidades de permitir ao oluno perceber suas emoçōes e reconhecer seus sentimentos. Com is5o, dificultamos a possibilidade da descoberto de si, do outro e do mundo.

Ler, ouvir e produzir poemas desperta, além de pensamentos, sensaçōes, emoçōes e sentimentos. Poesic é trabalhar com a emoçāo, brincar com a imaginaçāo. Vamos entđo "dar asas ds nossas enoçōes e imaginaçāo" e levar os alunos a compor um poemo lírico, ou seja, um poema que expresse sentimentos.

\section{Atividades}

4. Salicite aos alunos que escolham uma dos poesias do mural. Apos umo leitura, peço-lhes que representem em uma folha de papel, com linhas. troços e cores, o que sentiram co ler a poesic.

Cada aluno pode mostrar seu desenha para a classe, e você, professor, pode conversar com o grupo, mostrando a variedade dos sentimentos. Nōo há certo ou errado - apenas sentimentos diferentes, pois somos diferentes.

E no nosso dia-a-dia quais sentimentos aparecem? Raiva, medo, alegria, desânimo, esperança, amor... Quando sentimos cada um deles? Foça junto com seus alunos uma lista dos sentimentos que apareceram na conversa e transcreva-os na lousa.

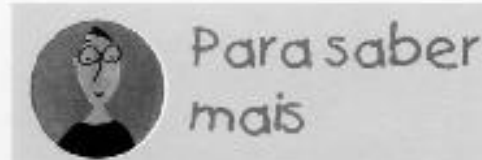

Lirismo: modo de exprimir-se em que o poeta fala de suas emoçöes e sentimentos intimos; em quase todas as épocas os poetas falam de amor.

Roseana Murray. Pequeno glossário de poesia. In: A ballarina e outros poemas. SĀo Pauln: FTD, 2001 v. 1. sentimento com que mais se identifica no momento. 
Peça-lhes que fechem os olhose pensem em palavras soltas que se relacionem com esse sentimento. Após alguns minutos, cado um deles pode escrever as palavras em que pensou, o que sentiu.

* Os alunos devem agora juntar-se em pequenos grupos de ccordo com o sentimento que escolheram.

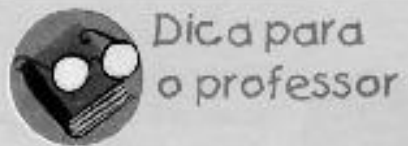

Não se esqueça de que todos os alunos devem contribuir para - mural pelo menos com uma produçāo.

Q objetivo desse procedimento é

tentar criar um poema com base no sentimento; afinal, jã podemos nos arriscur a produzir poesia. As palovras escritas de cada aluno podem ajudar a compor o poema do grupo. Peço-lhes que releiam o que escreveram. Da para intensificar a sonoridode?

3. Solicite-lhes que pensem em uma forma de apresentar as poemus criados.

6. $E$, por fim, peço oos olunos que selecionem os desenhos e os poemas que voo para o mural.

\section{Dedo de prosa}

Prcfessor, envolwa-se também nesse orazer de brinca com as palavras. Mexa con suas emoçōes e rabisque alguns versos de um poema criado por voce. Mostre-o para os alunos e deixe claro que wocé tamœém gosta daquilo que está ensinando. 


\section{Oficina 12}

Tecendo poemas

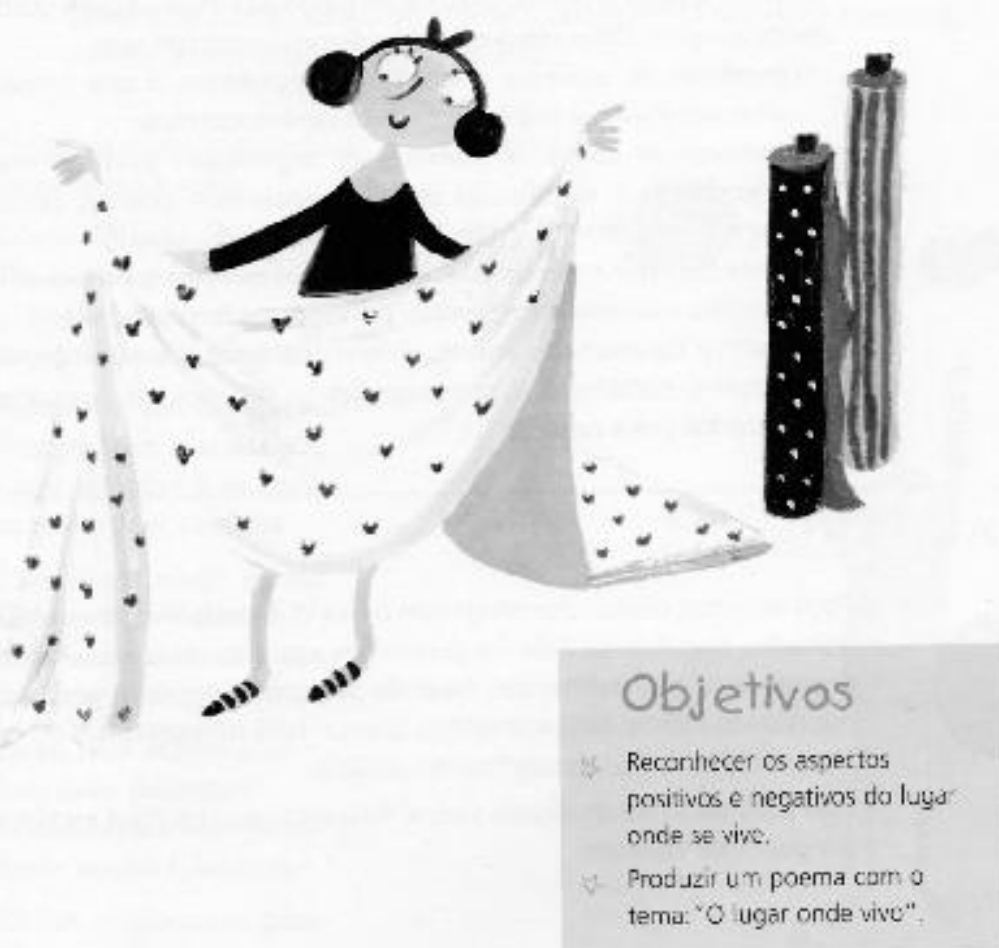




\section{Dedo de prosa}

Professcr, vuce loi convidado, no inciu do trabalho, a cuidare guardar a história e as produçces iniciais dos alunos. Agora elas säo essenciais para a balanço do passeio pelo mundo da poesia.

\section{Conversa com o professor}

Finalmente, chegamos à oficina no qual seus alurıs produzirũo poemas, alguns dos quais serāo enviados para o Concurso.

Antes, porém, vamos rever todo o processo para resgatar tudo o que aprendemos.

O mural que foi sendo construido ao longo das oficinas pode ajudar neste resgate. Olhando o mural, podemos constatar que:

- relembramos, ouvimos e lemos vórios poemas, o que amplísu nosso repertório e nos trouxe novos conhecimentos;

- observamos como os poemas se organizam graficamente, aprendemos o significado de vários palavras: poema, poesia, poeta, verso, estrofe, estilo, lirismo, tema;

- vimos que, por meio da poesio, podemos reconhecer e expressar emoçóes e sentimentos, evocar paisagens e fixar cenćrios; - ficamos conhecendo rimas, diferentes tipos de poemas, aliteraçc̄es, metáforas e comporoçōos - recursos de linguagem utilizados pelos poetos.

\section{Atividades}

- Peça oos seus al unos que observern o mural. É hora de admirar todo o trabalho, orgu har-se dele. Pergunte-lhes o que aprenderam. Ajude-os a organizar os conhecimentos, fazendo perguntas, dando sugestōes, apontando falhas, esquecimentos. Use os itens apresentodos na "Conversa com o professor" como subsidio.

if Leia para seus clunos alguns versos de poetas cue tenham escrito sobre o lugar onde viveram. 
Alma cabacla

Paulo Setúbal

$\mathcal{E}$, na dacura que encerra Esta simpleza daqui,

Viver de nova, na serra, Entre as gentes desta terra, A vida que eu já viui...

Obras completos.

Sco Raub Scraiso, 1958
Canfidência da itabirana

Corlos Drummend de Ancrade

Alguns anas wius em Itabira.

Principalmente nasci em Ftabira.

Par issa sau triste, argulthasa: de ferra.

Naventa par centa de ferra nas calgadas.

Oitenta par centa de ferra nas almas...

Sentirsento an munda, Rio de Janeiro: Record, 2001.

5. Leia também para cles a poema "Entre drogas e pardais", de Thiago Tavares de Araújo, aluno da $5^{2}$ série e vencedor da categoria Poesia do prêmio "Escrevendo o Futuro" de 2002.

Entre dragas e pardais Thiogo Tavares do Aroújo

En sau Thiaga Jaures, Menina da periferia, e, apsesar das pesares, uiva cam muita alegria.

Passa nãa ser tãa famasa, Mas da vida sou artista, e vau retratar meu bairra de mada bem realista.

$\dot{E}$ un lugar muita banita. Diga mesma "especial", Pois, apresar da descasa, Cantinua bem legal!

Lá eus wira minhra vida Cam tada felicidade. Pé descalga e bāin de cruma, Curta minha likerdade.

Lá tem muita caisa feia. Nãa escanda de ninguém. Moleque usanda draga, Emuita lina também.

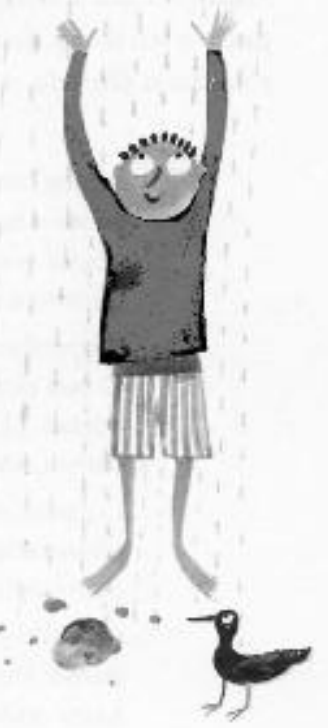


Jem genle desempregada, Jem rua esfuracada, Multer senda estuprada. E scuide deseuidada...

Nãa há lugar na munda Que se campare aa mes. Gairra. É é que maram meus pais, Meus amigas, minha gente, $\varepsilon$ ande auca cantente $A$ cantiga das pardais.

O meu primeira amar Jambém mara na meu bairra. Andamas bem diferente, Eu a pé e ela de carra Ela que runca gripa, E eu cheia de catarra.

Mas se quera dar uma flar A minfra dace amada, Esquega tada a temar, pula a mura da dautar e rauba a flar da madrugada.
Nãa quera que Фeus me dê Uma vida bem methar, Se a prega tiver de ser 0 men bairra esquecer. Pais esquecenda as raíges Me tarna um hamem pias.

Quera marar na meu bairra Par toda a minha vida, Aluara Weyne, querida, Cam esta gente safrida, Anânima e esquecida...

Que sabe se superar, Cantar, viver e sanhar, Pais. pras problemas driflar, Basta ter fantasia, só pra vaar, $E$ alcangar a sanha da alegria. Escola Municipal Profesara Maric Roseli Mesquita - Fertelicza/CF

Agora convide seus alunos a fazerem o mesmo: escrever um poema sobre o lugar onde vivem. Para isso, monte, junto com a classe, um poinel - vocé pode usar a lousa como base, cobrindo-a com um papel ou vórios popéis emendados.

Proponha ao grupo que imagine aquele espaço como o lugar onde vive. O que eles gostariam de representar? Praças, rucs, construçōes, árvores, postes... Enfim, o que existe em coda lugar. Os alunos podem usar lúpis, fazer cologens, ou usar até mesmo tinto, se for possivel, para desenhar.

O poinel deve ser um trabalho de equipe e, por isso, requer planejamento. Näo se esqueça de dividir tarefas e funçōes antes de planejor os etapas.

Quando o painel ficar pronto, peça a cada cluno que olhe para ele $e$ pense: Do que eu gosto no lugar onde vivo? Do que eu nāo gosto no lugur onde vivo? 
Cada aluno escolhe, entao, uma polavra que expresse urn desses sentimentos e escreve-a em um pedaço de papel.

z. Cada aluno escolhe um lugar no poinel para colar suo palovra. Peça aos alunos que olhem o painel. Como ele ficou? Conversem um pouro a esse respeito. O que podem falar do lugar em que vivem?

\$. Vomos iniciar, então, a produção do poema. Para escrever um poema, cada aluno vai tomar algumas decisōes em relaçōo a seu texto.

- De acordo com o tema dado - "O lugar onde vivo" - e com as palavras pregados no painel, cado aluno deve escolher sobre o que quer falare fazer um primeiro rascunho, deixando ofloror a emoçäo e soltando a imuginaçāo.

- Depois deve se perguntar:

$\checkmark$ O poema terá rimas, aliteraşōes, repetiçōes de palavras ou versos? $\checkmark$ Como será intensificada a musicalidade do linguagem?

$\checkmark$ O poema seró composto em quadras?

$\checkmark$ Será um poema de versos livres?

$\checkmark$ Ou dividido em estrofes?

$\checkmark$ O poema vai expressar sentimentos, emoçōes?

- Com base na revisão e nas decísōes tomadas, cada aluno deve reescrever seu poema quantas vezes julgar necessúrio. 
Oficina 13

Dando o toque final aos poemas

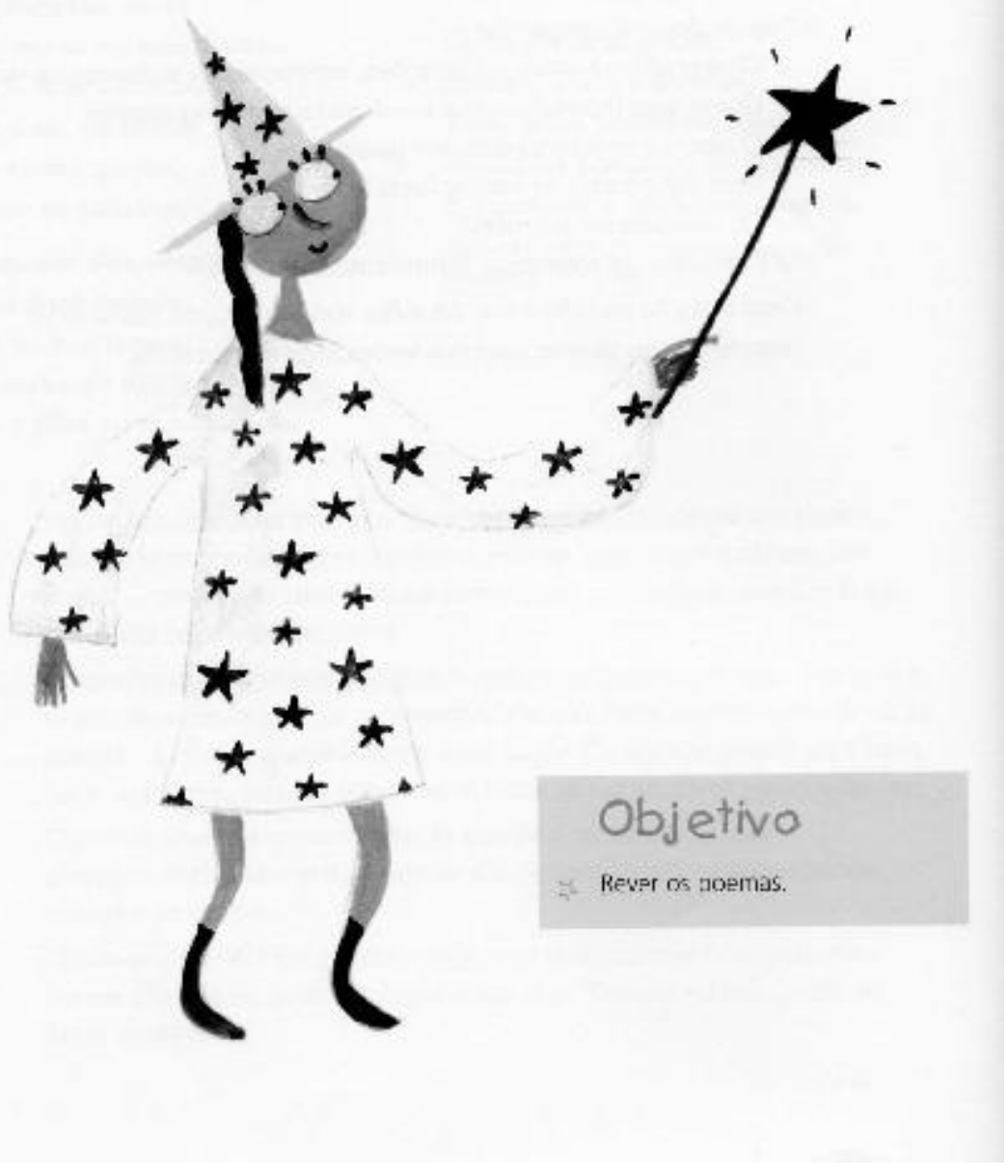




\section{Convers a com o professor}

Poesia è um texto que se caracteriza por múltiplas formas sem que se prenda a regras.

Mas alguns itens podem constituir um roteiro para uma revisāo final do trabaho.

\section{Atividades}

7. Coloque no quadro os itens abaixo e peça a cado alunu que verifique se seu texto preenche, de forma satisfatória, todos eles.

- O poema tem título berr sugestiva?

- O texto estú apropriado ao tema?

- Que reaçāo se espera do leitor ao ler/ouvir o poema?

- O poema enfotiza um aspecto especial do lugar referido no tema?

- O poema manifesta alguns dos recursos trabalhados nas oficinas (rimo, quadra, aliteraçāo, compcraçāo, verso livre, lirismo)?

Depois que os textos forem revistos e eventua mente reescritos pelos alunos, consulte os critéríos de avaliaçāo - que serāo usados pela Comissão Julgadora e que estc̄o no livreto $C o ́$ entre nos - e aponte pora as crianças os problemas que persistem no texto, mos deixe a correçāo por conta delas.

Só depois disso é que vocè pode pedir-lhes que passem o texto a limpo. Escolha, junto com seus alunos, os tr8s melhores textos de sua classe e envie-os para a Comissõo Julgadora da escola que escolherá o texto premiado. Esse trabalno finalista deve ser registrado no folha timbrada do bloco encaminhado no kit. Não se esqueça de anexar a essa produção final o primeiro texto produzido pelos alunos na oficina 3 .

\section{último de do de prosa}

Professo; poesia rima com alegria. Faça, pois, uma festa para receber reco her, apresentar e expor os poemas feitos por seus alunos. Afinal, depois de muitas of cinas, na maioria das vezes com a produção de outros aurores, agora é c trabalho de vocès que está pronto. Comemore! Cada qual a seu modo, com seu alcance, com a dose certa (ou ncerta) de emoçäo, com seu jeito de ver, rever e revirar esse mundo onde vivemos todus, Parabens e... sucesso oara todos os seus novissimos poetas brasleiros! 


\section{Palavras (quase) finais} APÊNDICE

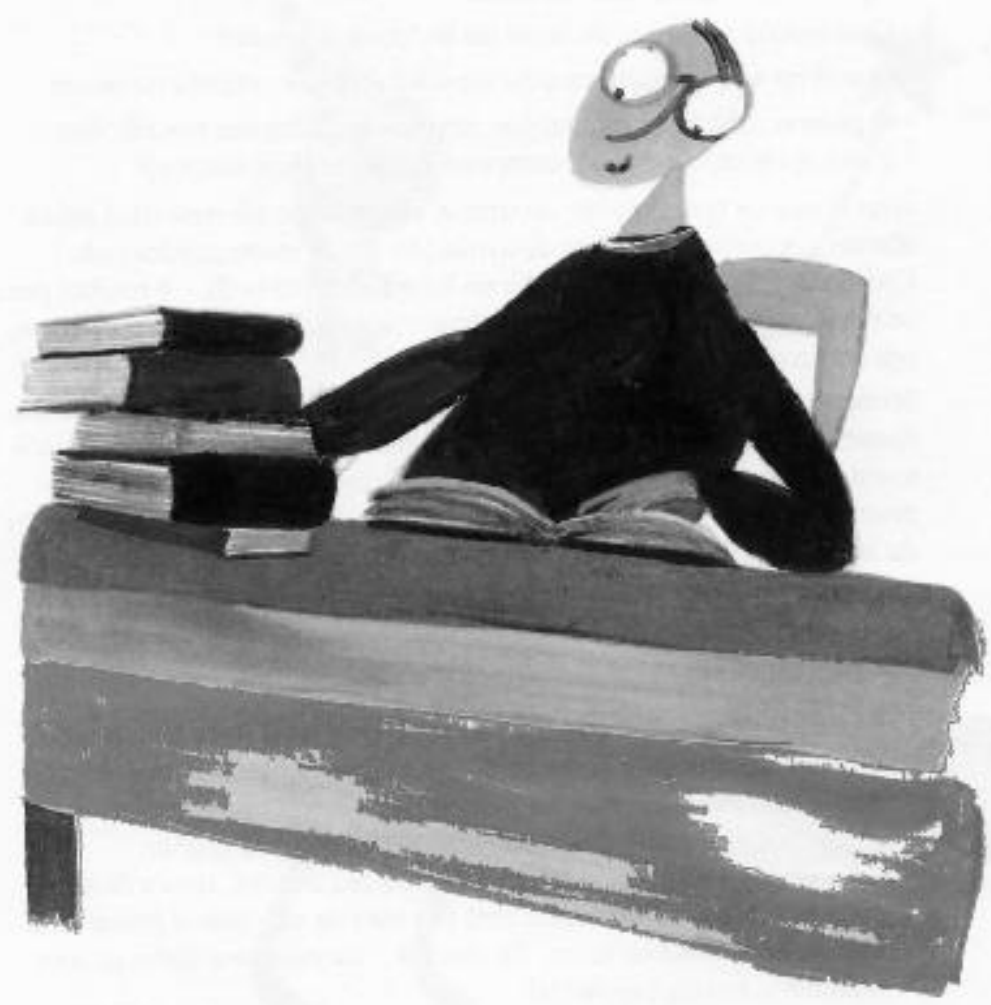




\section{Um de do de prosa sobre a conversa que nâo} acaba aqui

Pois è, professor... Encerramos egora escas atividades sobre puemas. Isso nào quer cizer, é claro, que seu trabalho terminou, porque trabalno com leitura e escrita nunca acaba: um texto vai puxando outro, como uma conversa sem fim..

Os textos escritcs conversam entre si e com todas as linguagens que $\mathrm{c}$ homem à inventou, uns marcando os outros.

Neste texto que produzimos, estamos, é clam, conversando com voce, que está lá na sala de aja, "pondo a mào ra massa". Estamos também, ao mesmo tempo, conversando com muitas outras pessoas que disc.tem ou discutiram a escrita e seu ensino. Pensamos que talvez você tambèm gostasse de conversar com algumas dalas. Al vai, enllao, uma pequena relaçáo de livros e textos.

\section{Referencias Bibliográfic as}

BERALDO, Alda. Trabaihando com poesia. Suo Paulo: Ática, 1996. v. 1. GOLDSTEIN, Norma. Analise do poema. Säo Paulo: Ática, 1988.

GULLAR, Ferreira. "O prazer de ler". in: MURRAY, Roseana. Bailarina e outrus pcemas. São Paulo: FTD, 2001. v. 1. iPrograma Literatura $\mathrm{cm}$ minha casa)

LAJOLO, Marisa. "Carta aus leitores". In: LEITE, Maristela de Alme da \& SOTO, Pascoal (coords) Palavras de encantamento: antologia de poetas brasileiros. Săo Paulo: Moderra, 2001. v. 1. IFrograma Literatura em ninha (asa).

Do mundo da leitura para a ieitura do mundo. 5. ed. São Paulo: Atica, 2000. (Coleção Fducaçăo em açāo).

\& ZILBERMAN, Regina. Literatura infartíl brasileira - História e histórias. 6. ec. São Paulo: Atica, 1999. (Coleção Fundamentos).

LIMA, Ricardo da Cunha. De cabeca pra baixo. Săo Paulo. Compantia das Letrinhas, 2000.

MACHADO, Ana Maria. "Poesia: semente de toda a literatura". In: ANDRADE, Carlos Drummond de ct al. Cinco Estrelas. Rio de Janeiro: Objetiva, 2001. 


\title{
Textos indic ados
}

\author{
Sertäa \\ Asceriso ferreirc \\ Yertĩa! - gataba!' \\ Iertäa! Cabraba!! \\ - Cabrabá! \\ - Ouricuri! \\ - Exu! \\ - Exu!
}

Lá vem a vaqueira, pelas atalhos,

Jangenda as reses para as currais...

Blém... Blím... Além... cantam as chacalhas

das tristes bades patriarcais.

$E$ as guigas fininhas das avelhinhas ternas

dlin... dlin... din...

E a sina da igreja velha:

Bãa... Bãa... Gâa

[‥]

Poemos de Ascenso ferreiro. Rec fe: Nordestal, 1981. p. 26.

Caisas da seina da minha cidade

Cora Coralina (nome literário de Ano Lins dos Guimarães Peixuto Bretas)

Olha e veja par cima das telhadas patinadas pela tempa cupadas mangueiras de quintais vizinhas.

Altaneiras, enfalthadas, encharcadas seus caules,

Trancas e raizes das langas chusas da verãa passada.

Paramenladas em verte, celeiram a liturgia da práxima flarada.

Antecipam a primavera na revestimenta de brataçãa iranzeada, ande esecagam forbaletas amarelas.

As manqueiras estâa canuidanda tadas as turistas,

para a festa das suas frutas maduras, nos reinas da minha cidade

Estas caisas nas reinas de Goias.

Vintém de cobre - Maias Confissöes de Aninhia. 8. ed. Sao Faulo: Global Editora, 2001. 


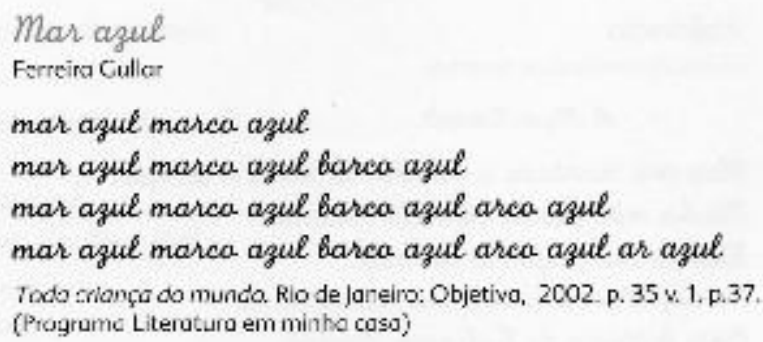

Episádia sinistra de Virgulina Ferreira (II)

Carlos Pena Fil no

A feira de Vila Bela

tem chacalthas para vacas.

Na feira de Vila Bela,

feijâa e pá nas karracas.

Na feira de Vila Bela,

arreias, cardas e facas.

Na feira de Vila Bela,

chapés de coura, alpercatas.

Na feira de Vila Bela,

un ceguinha pede esmala.

Na feira de Vila Bela,

a cega e sua viala:

- Dana, siga a meu consetha, vá regar uma araçãa,

parque eu já veja a distância

a ira de Lampiáa.

Fiquem somente as soldadas, a sargenta e a capitãa.

Fiea eu também que saus cega

Eñ̃a sei da claridade.

Ye Lampiäa me matar,

mata samente a metade, que a vutra já levau Deus

par sua agreste vantade.

[...]

Liwro gerai. 2. ed. Recife: Grafica e Editora Liceu, 1999. p. 26. 
Infancia

Carlos Drummond de Antrade

$$
\text { A Alagar Renaute }
$$

Meu pai mantaura a cauala, ia para a campa.

Minha mãe ficaua sentada casenda.

Meu irmâa pequena darmia.

Eu sagintia menina entre manqueiras

lia a Ristária de Rabinsan Crusaé,

camprida Ristária que näa acala mais.

Na meia-dia branca de luz uma vag que aprendeu

a nintar nas langes da senzala - e nunva de esqueces

chamava para a café.

Café preta que nem a preta velha

café gastasa

eafé bam.

Minha mãe ficaua sentada casenda, altanda para mim.

Psir... Näa acarde a menina.

Pára a berga ande pausau um masquita.

E dava um suspira... que funda!

Lá lange meu pai campeaura

na mata sem firm da fagenda.

Eeu näa sabia que minha Ristária

era mais Canita que a de Rabinsan Crusaé.

Cinco estrelas. Rio de Janeiro: Objetivo, 2001, p. 25.

(Programo Literaturo em minho casa)

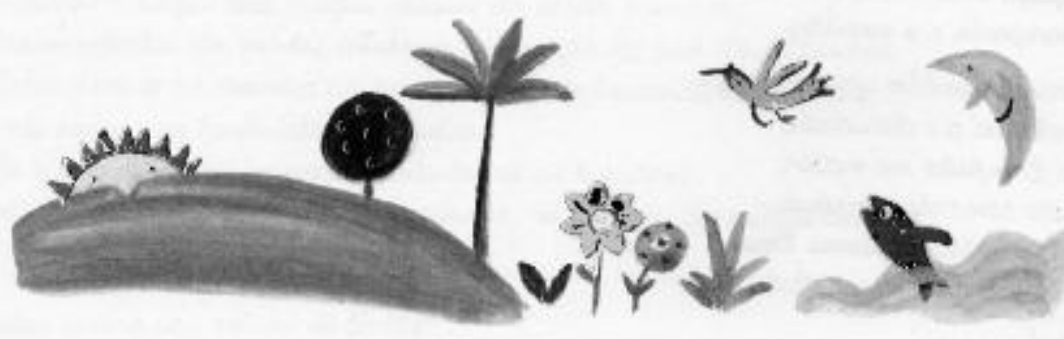


Na rua Mária de Andrade Nuncel de Barros

Na rua Mária de Andrade

vau andar

Par ter sida. Jarumã e haje ser Mária de Andrade Ainda näa sei unde é mas uou pracurar na rua Mária de Andrade wou andar...

Vau is cam Macunaima sente às paredes vou ir cam Mária de Andrade Ele, Mária, me diz: é precisa flanar...

Eu diga a ele - ó Mária, era a que eu ia te falar É precisa flanar em ruas. - as passas levanda sempre para nentum lugar

E Mária me diz: - Poeta, nenthum lugar é a melhar lugar de um poeta chegar Nũa há que ter nem camega. nem firn essa antiga sua Jarumā Cama serāa seus maradares? Vau até lá

Yaberãa quem foi esse hamem bam a da sua lapes eAawes? Bem mas também ele nãa sabia quem fara Lapes Qhaves. Nãa há cama nãa saber quem fai a name da rua em que de marau ou vai marar fe name de gente, é lam que ele desaparega campletamente

Näa seja mais nem lembranga nem a sambra de um hamem. - coma queria a paeta Bandeira Jalve meltar canservar rua Jarumã mas vai ver que lá nãa existe um pé de tarumã! sequer uma crianga que conhega tarumā [...]

Se hauver ffares nessa rua Mária de Andrade a ladas nás ela agradará

Ie haver sabradad liricas. cam janelas aquir ou verdes pranta!

Cromática expositiva do cháo: poesia quose tocka. Rio de janeiro: Civilizaçao Brasi eira. 
Cançãa da exilia

Gonçalves Dias

Minha terra tem palmeiras Onde canta a Saliá,

As aves, que aqui garjeiam,

Rãa garjeiam cama lá.

Rassa céu tem mais estrelas,

nassas wirzeas tèm mais flares,

nassas basques tìm mais uida,

nassa vida mais amares.

Em cismar, saginha, à noite,

Mais prazer encantra eu lá;

Minha terra tem palmeiras,

Onde canta a Sabiá.

Minha terra tem primares,

Que tais näa encontra es cá;

Em cismar, saginha, à noite,

Mais prager encontra eu lá;

Minha terra tem palmeiras,

Onde canta a Yaliá.

Nãa permita Deus que eu marra,

Sem que eu valte para lá;

Pem que desfrute as primares

Que nãa encantra par cá;

Pem qu'inda aviste as palmeiras,

Onde canta a Yaliá.

Onco Estrelos. Rio de laneirc: Objetiva, 2001, p. 44 (Programo Literatura em minho caso) 
Na Minha Jerra

Alvares de Avevedo

Ama a venta da noite sussurrante

a Cremer nas pinfleirad,

e a catinga da pabre caminhante.

na sancha das trapeiras;

e as manátanas sans de uma viala

na tardia verãa.

e a estrada que alem se desenrala

na véu da escuridãa;

a restinga da areia ande relenta

a. aceana a Gramir,

ande alua na praia macilenta

vem pálida luzir:

e a néraa eflares e a dace ar cheirasa

da amanhecer na serra,

e a céu azul e a manta nébulasa

da céu da minha terra.

Os milharcs parnas de Alivares de Azevedo. Candito

Antonio (org) 5. od. Säa Poulo. Global, 2003 p 32

Pátria minha

Vinicius de Moross

[…]

Nãa te direi a name, pátria minha

Teu name é pátria amada, é patriaginha

Nãa rima cam mãe gentil

Vives em mim coma uma filtha, que és

Uma ilha de ternura: a gtha

Brasil, talues

Agara chamarei a amiga catavia

Epedirei que pega aa rauxinal da dia

Que pega aa sabiá

Para Evarte presta este avigrama:

"Pátria minha, saudades de quem te ama..."

Antolagia poétion. 3. ed. Rio de janeirc: Editora do Autor, 1960. D. 204. 
ANEXO 2 - Relatos dos professores (reprodução xerográfica) 
Relaten das perioncias virdas de hante a scperiencia no Concurse Escreven

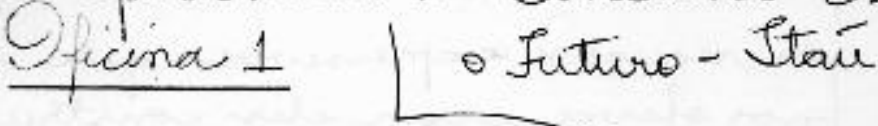

\section{Reconheando poesia}

Esta oficina foi interessante, pois os alunos entraram em contato com uma diversidade de estilos e tendencias po éticas, lendo, examinando, conheendo ese encantando com livios que possuím em casa, que notiravam ra biblioteca. da excola, que pexquisaram na biblio teca municipal. for, de certa forma, um estímulo, um comvite a presia, já que es ta $c$ a arte da palawra e por isso sen sililiza, toca, envolve um número mavo de pessoas que outros genenos testuais.

Opicina 2

Sabendo un prouco mais sobre poesia

fá mergulhados nesse unuserso encontador que é o da poesia, ficou mais facil aprender um poice onais sobre ses se modo diferente de arranjar, creaire Weriar palavras, reseltando am dera te arte. Qprencter algumas técnicas jocra

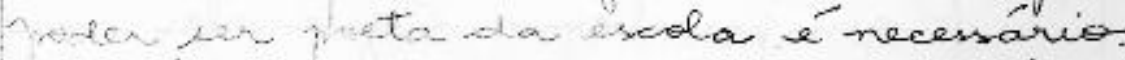

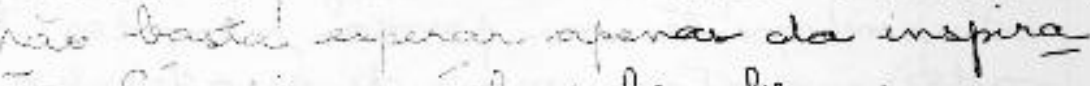
a. Eunditanat saler bruncar com as malaras de una fouma inteligente, -aver = and an ros rodeia $e$ in -

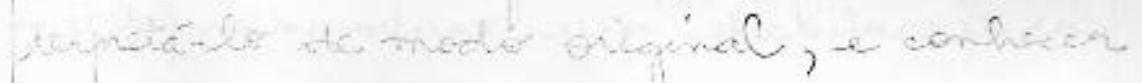


os recurses expressuves que a limgua nos offerece econ ales onstruir unagens surpuendentes, astabelece um yog soworo (rimar, aliteracers, arrenancias, reitoracoes, ek), solver or panizar toda a idéia em verwos estrofes ebedacendo or ritino, cadência custetica do proma. Essa fiervia garantir um modopinlegiado ar adivinhar a poescio es condida nestertos ace hamos (promas e prosa prética) Para isso, fazíamos vó vias lectiras, (proferrora, em vory alta) aluno, silenciasamente; pofesrana, de for ma expresiva, aluno, em vor alta, in. dividual coletiva, etc) partindo do prin cíprie de que todo técto nunca esoota a pasinbilidade de ser lido. A pengun ta para descolvimos se havia poesia naquele texte, de primeire onomento era. Ele havia nos tocado, sensibiligado? Ps sura magia, encanto?

\section{Oficina 3}

\section{Producate individual}

Esta oficina for mprotante, pois a traves dela" diagnosticames" an predue căo escrita de nowes alunos.

O que percebemos é que eles ache dutaviumbomerte em poemas rumados (tro vados) g gostanim mais de quadrinhas e ectilizaver em secus textos uma lin geagem bem enformal com mutas mar cas de oralidade que acabarrmempobre - 


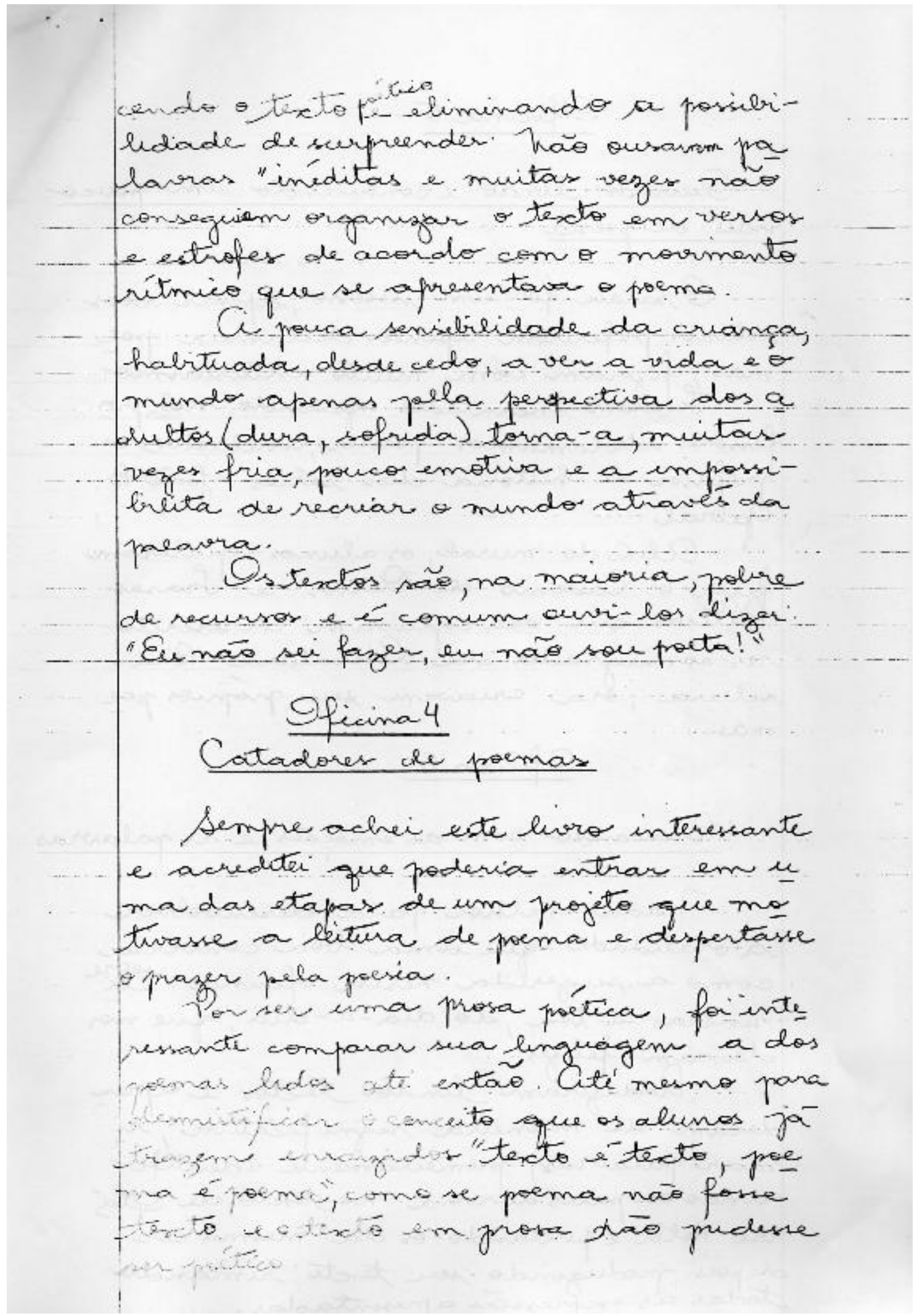




\section{Ofuina 5}

Ouvinde, lendo econhecendo um pouec mais de poesia.

O saran for um sucesse, apresar dos

alunos preferiem apenas declamar pae mas fofizeram com mitto entusiamo: Gcaram encantados quando nos, pre fessores declamamos poesia, inclusive proferson de história das séries foro 13. Gabriel.

Qlér do mural, os alumos quiseram fezer o Caderne de Pensos e frases Peticas que ora copraivam de escritores consagrados da Riteratura Brasiluia, sra creavam deus pópues poe mas.

\section{Pivia 6}

Druncando arr as emocoes e as palavias

Tada melhor para desenvolver a valudade gue uma ba conversa come a rengerlida nesta ofieina: cole surbias a toa, do dia-a-dia, que nos dercagn faluzs.

Roduziram lindos textos e aprien deram de manuia segnifecitiva, ri mar palavias, primeiramente identificando os praves de nima no tareto de Sitá vio Reter e piritando-os da masma cor, depois produgindo ser tercto, rumiando Ptodas as expressar apresentadas. 
Qficina 7

Bruncaindo um pouco mais com as palawras: rimase alderacoes

Essa ofiuna os libertou da necessi dade que tirham em fazer rumiare consciantizore-os da emprortancia maior aos recursar poéticos.

Qleñ de edentifecar os racursos lin guísticos para poderépioduzir efeltos so noros, rictmo, cadéncia frearam mais oriticos e com um gosto mais refinado a boa posia. Oprumoianam anda mais a ante de bruncar com as palaves.

\section{Ofucina 8}

Conberendo presia popular

Ifcaiam interessadésimos e acaba ram se dentifucando com esse tipo de proesia.

Qusaré fostilo popular de Patativa do som mas do gêrero: "Esse poita fala Wa rowsa lun-gua " e por ser escrito um uma linguagem simples, por

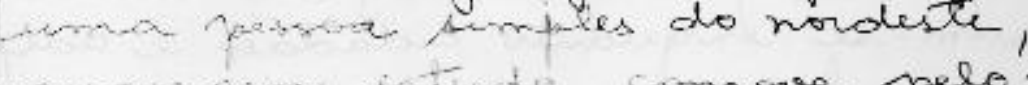
a a in bilidade de peder gex oc a we.

$$
\text { Colmoram faz acrósticos e }
$$


classe. Uma forma que incentraram de revelarem-se sem ter que se Gipares: Wh, esacrósticosque mantarame dos mofosseres fovor maximo e revelosam todo $\theta$ concicto que estabelecem conoser.

\section{Oficina9}

Pendo $\theta$ mundo de um modo poético

Educar o olhar para encarar as coisas ale forma mais idealizadora, com otimum talvez pudese ser ene of obje twive maior dessa oficina.

Quem é sensivel, percebe e lê $\sigma$ talver sofra mais, porém nunca dei$x$ a desonhar.

Clém de produzir bans texts poe ticos, expressivos, envotivos a proexía torma a vida menos dura e as persas menos agresswas e indivipenadas. For exatamente esa melhora decomfor tamento que senth ao témino dotrá ballo com as oficinas. Qlém de interdiciplinar, considero ese projeto trans duscipleniar, pois as criangas desenvolveram-se enquanto adadáos. e adqui reram bagagem para entinivar of crestitando que viver estidar va Ile a pona!. 


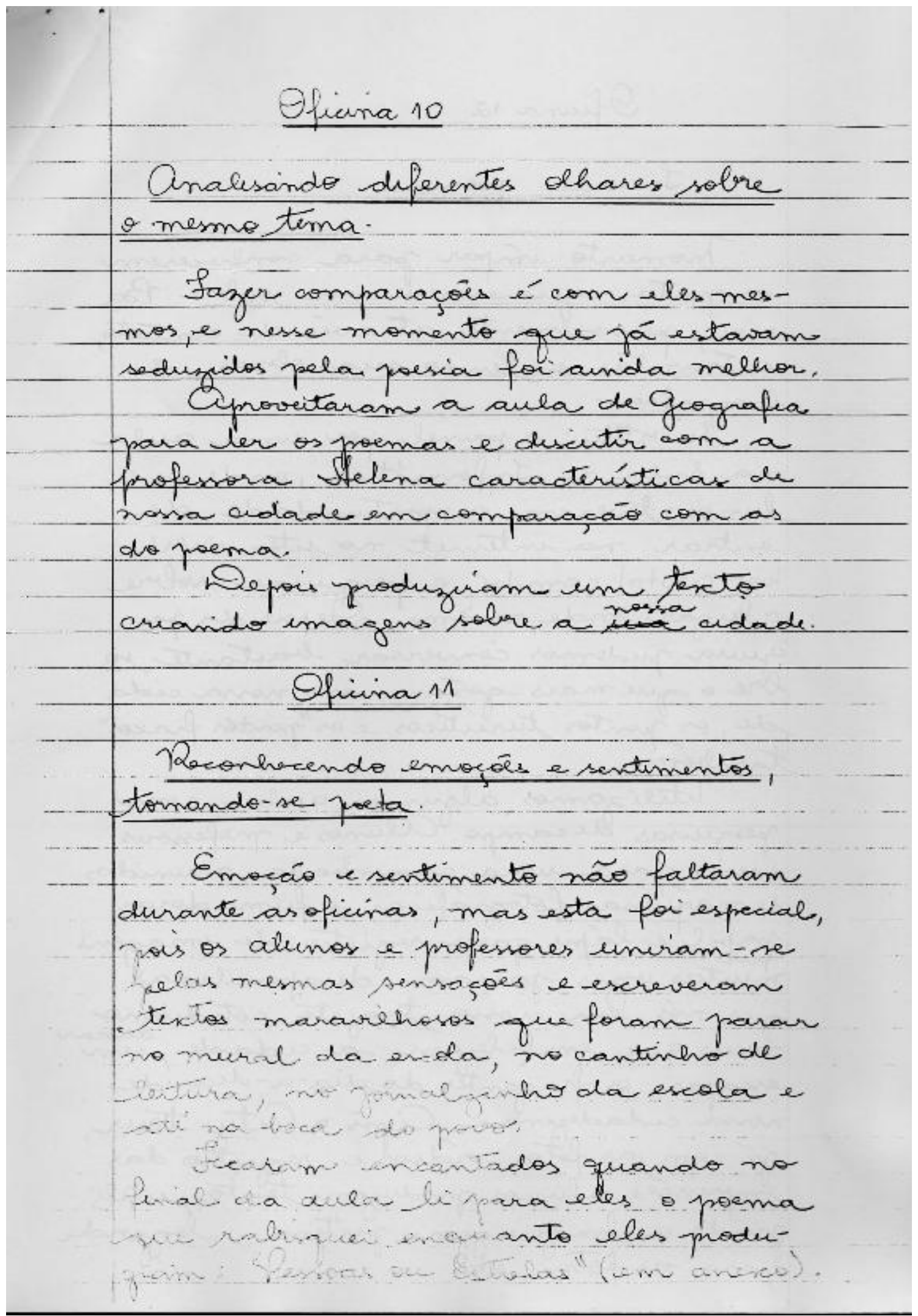




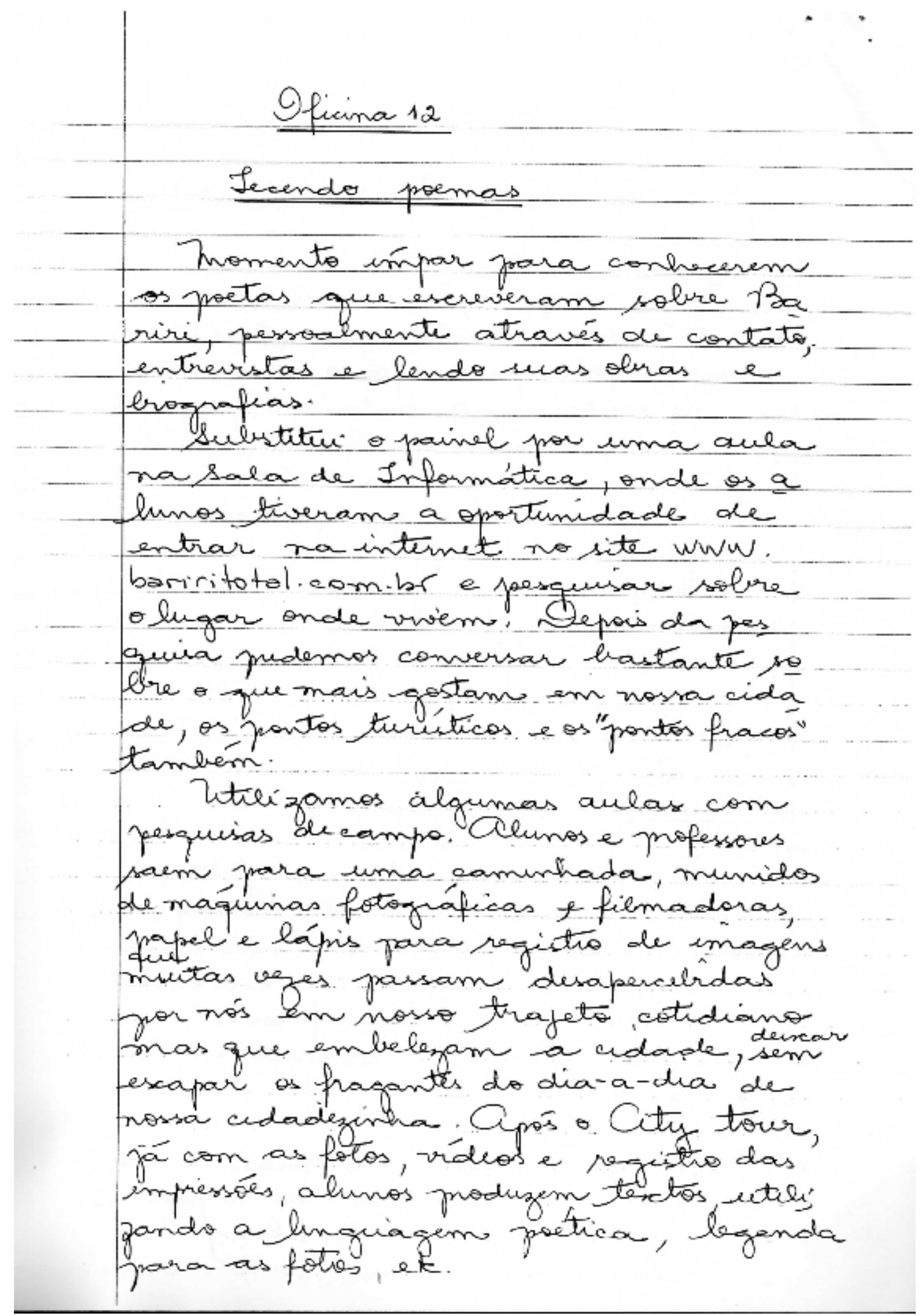


Qlér de educar um novo dehar sobre o que vemos, oficinas corno essa despertam o prazer pelo ambrente, pelo mevo em gex vivem e come consaquên cia a valoriza páo do mesmo e ocle semolvimento La cidadania.

Clim de ler otexto: "Entre drogas e pardais analusainos en congeinto os recursos póticos utilizados pelo grande vencedou $/ 2002$ - Ihuags S.de Graijo.

\section{Oficina 13}

\section{Pando o toque funal aos pormas}

Essa for a hora do leitor-crético que aprumira o tercto como * ounives lapida a pedra brita.

Oproveitamos esse momento jara froca de terctos entre eles para uma prossível avaliacáo dos colegas e depois o momento final resenevé lo, aperfer Grando- $\theta$ aunda mais.

Or eritírios de avaliajáo do luve to "Cá embre nós" foram afresentados ces olumos para uma referato sobre - tercto final. E um Ĺletimo momento: - warbê lo movante, agora mais

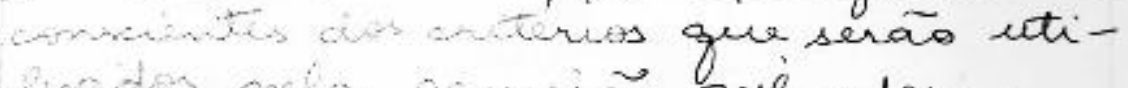
andes patio cemusiar yulgadona Pal wa (quase) finais 
Os terctos apresentados aqui tambern for an lidos e explovados ermsala de aula e a Bibdigrafia tankbém senviu como suprete joeda gógice no desemolvimento denosse thabalhe.

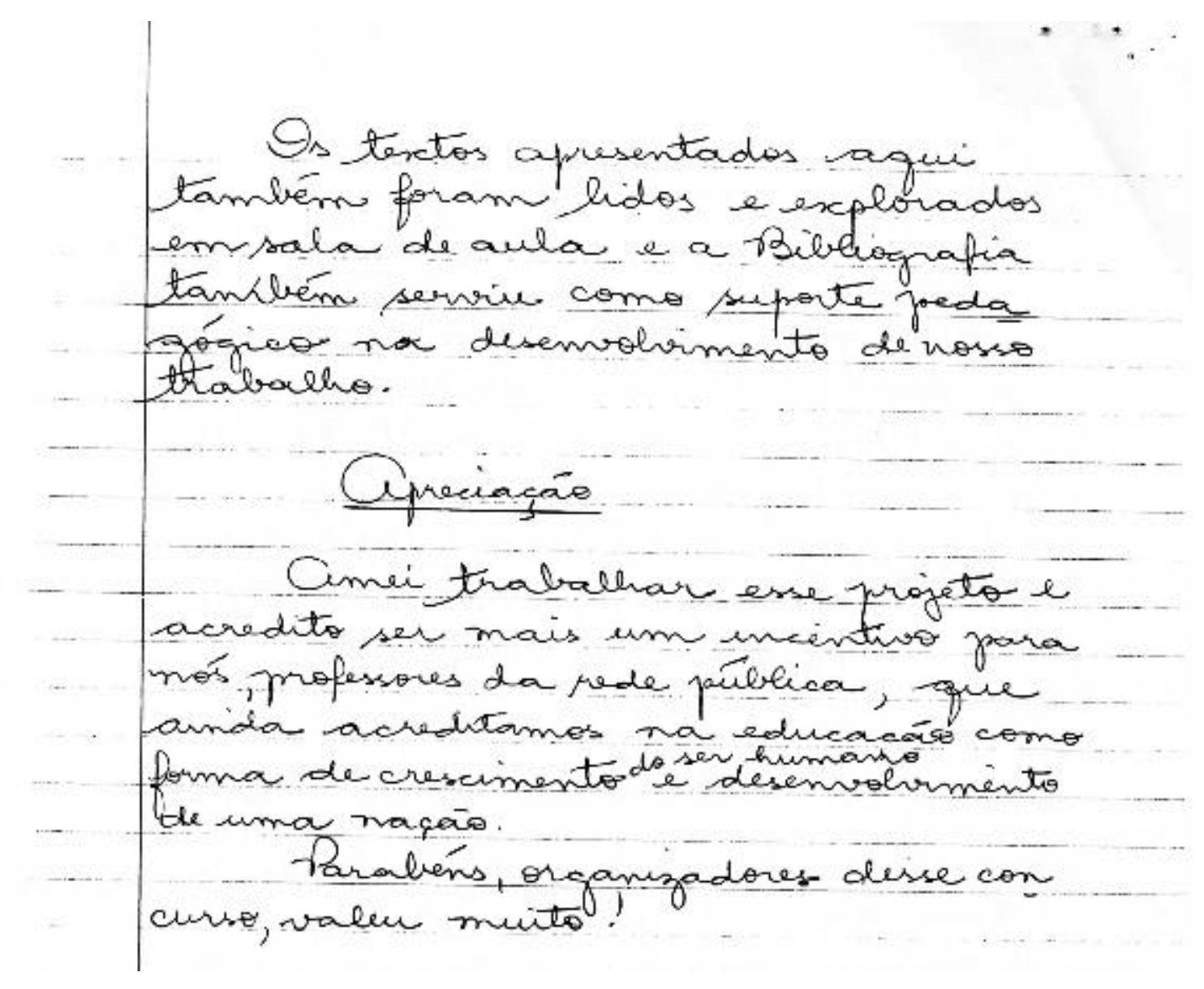


Regustro das experiências realizadas an sala de aula Periode de funino a agosto."

Cupós neveber o Kit Itau de Giacão de Textes e feite a escolha do ginero poesia, proucuri integrar me completamente de esnteide.

Minha prescupacono for grande, apesar de trabalhar com poesias em sala de aula, et maximo que neus alunss faziam eram quadras, acróstices, interputaçäo de posias e de letras de misicas.

Cipresentei para les o Programa Escrevendo o tu turo, explicando suas etapas. Comentei solve os prêmies, prourando incentivá-los.

Notei un total desinteresse sobre $\theta$ assunto, fiquei um pouco desanimada, sim saber par onde co-mecar.

Fiquei uns três dias falando com eles sobre o tema, falando sobre a nossa cidade, fazendo comparacóes, contando corias que ele näs vonheciam e fin perceluendo o interesse de alguns.

Um dia, chequei ra classe, formei greupos de qua tro e decidida comientei que iriamos fazier os combina foram fitos di acondo com que les propunham, es critos na lousa i depois passados em coutolina é fixa dos na parede.

a primeira negra observada, for a participarão de todos.

sugeri que trouncessem para a próxima aula poesias que tivessem en casa. Poucus trouxeram. intão foms ate a viblicteca da escola e pedi que separassem somente lives de presias. Sintamus a mesa, todos ficaram lendo as 
persias que encontraram Observei alguns desin teressados e outus que comentavam: achic uma de Slave Bilac sutre que achou uma de Qlias fosé, Cicilia mireles i assim foram des colrindo e lendo.

Livamos para a sala muitos lives que fo. rom colocados nas mesas, à disposicäo 2 interés se deles. Clguns pediram para levar para casa. Eu deincei.

Comecamos a trabalhar as oficinas contidas no luiv: Psetas da Escola.

Os alunies fá haviana aprendido sobre rimas, versos, estrófes, mas achei melhor reforcar. Omen interesse, tra liva-los a interpretacáo mais pro. funda, descobrindo inovizes, sentimento, sobre as poimas apresentados e foi isse que mais trabalka Com os grupos formados, as perguntas que fa. pia i atividades, eram respondidas solere \& ponto de vista do grupo.

Netei que ainda havia alguns disinteressades, mas não desisti

Pedi para que cada crianca lscrevesse um poema corn otema: O lergar sinde vivo. Nem to, Los conseguiram fazer.

Para incentiva-los, convidei o professor fairo, supervisor na Wiretoria de Ensine, que l'umpota Cle atendeu-me prontamente, veie ate minha sala - passon horas, conversando com as alunos 2 dedamando poesias de sua autoria. Oleserver que as criancas gostaram muito Thar dividas e aprimonar meus conhecimentos. Propus intâs para os alunos, que escreves 
sem outre poema com o mesme tema e fie ajudando os mais interessades na construcão de algums versos com rumas, ha erganizacaio dos. assuntos, divisão de istróles, sxpressão de sentimintos, verificando se les nä saiam do tema. Vesta vez frqui mais animada, não pela quantidade de pormas escrites, mas achei que havia un vescimento de idivas por parte de algums na apesentacäo dos poimas. Colora. os no mural, que ja havianos fito e notei que os desinteressados levantavam 2 iam ate' * mural ler as porsias.

Por pecasião da Reunião de Pais, do $2^{\circ}$ Bimestre, apraveiti a oportunidade para falar mais sobre o assunto \& pedi aos pais, que incentivassem seus fillos na escrita de poemas com ot terna sugerido e qui contassem a les sobre o passado do muniápig enfim, que conversassem solve fatos ocovidos, os higares mais importantes da nossa pequena cida. de.

Es estava muito envolvida e anciosa esperan. do um retorno de tudo que estavamos trabaChando em sala de aula.

Irei procurada por algumas mäs interessadas. em azidar sus filhos.

Gontaria de ressattar, que a minha escola épequena, temos alunos de $1^{a}$ a $4^{a}$ séries, manhá e tarde. Sä alunos carentes, alguns com poder aquisitivi um poucio melhor, poucos säs os pais que cursaram até a 4a série e isse dificultou uma adisão maior.

Iinaimente mês de agasto, chegou a hora da clas se elaborar ss poinas. Quere dizir que nă foram to. dos que conseguiram, mos uma gande mavoria. 
Alim da colaboraça do professor gairo a do men total empentio, tive usn gaande apoiv da diretora suls tituta, que tambim e' professora de Lingua Patugue sa, Cosma. Ula não mediu isforcos para ajudar me. Una equipe foi montada para a iscolla dos tra. balhos apresentados, o que näs foi facil dicidir, porém o poima de funior chamou mais atencäs, $A$ maio. ria decidiu por classificálo como is melhor pie. ma apresentado.

(Q) pouna foi uncaminthade no dia 18 de agosto 2 firiames anciosos pelo resultado.

Nia 5 de sutubre, receli a grande noticia imen aluno havia sedo escothido para a pase semifinal de programa. Fiquei radiante en dia seguinte quando die a noticia para funior, notii que sus thos britharam, percebiemecaie, mide talvez, do des contrecidor.

Os alunos corriram para abraca. lo e pude perce. bir que todos ficaram felizes pela conquista de funier. Com a volta da diretora efetiva: Sueli são foũo Prado, responsável pela nossa inserica no concurso, mais uma viz ela uncentivou-me, encheu meu coracão de es perancas e coragem para infrentar essa nowa tapa.

Estamos pois, en e Gunior, hos preparando para contecer são paule, participar das oficinas de elabonacáa de tuxtos, fazer novas ami zades i aprimonar mossos conhecimentos. 


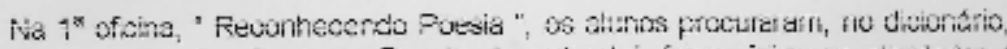
saber a drerença entre Foema e Poesia. A partir dai, foram ietas as atvidaces ( grupo) de transcriçso de poemas para colocar no mural.

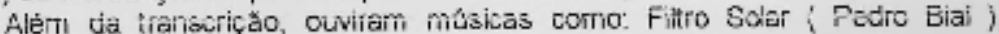
Planeta Agua i Guilherme Arantes ) para perceoerem a poesia dentro da música.

Náa $2^{a}$ oficina, " Sabendo um pouco máls sobre possia = îzerain as noservacós pertinentes as atividades propostas, cópia e leltura do peema ${ }^{2}$ Terr tudo a ver " (Elias Jose) ). Em seguida, interpretaram cada vereo e definiram versos

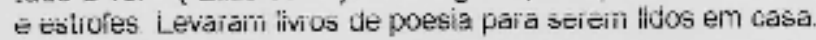

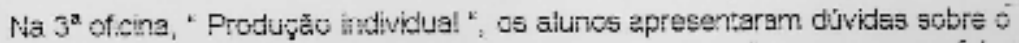
tema. Ees nao conseguiani entender o que tad para ser escrito, se era pala fááí sobre a casa a rua, o bairro, a cidade.

Sugeri que pensassem em tudo aquio que tazia parte co seu dia a cha, os iugares que freqüeritavam, a que faziarn, como viviam.

Na $4^{*}$ ofnina, "Caladures de poenas ", os ahunos theram contatu sum um inro oe poemas de um poeta de nossa cidute e mais ivros para serem iidos em case

Na $5^{\text {a }}$ oficina, - Ouvindo, lendo o connecendo um pouco mas de poesia : forarn lidos furce da Literatura em minha case, ouviram os poemas do final do fascicuio ( Poetas da Cscola ), depvis foi feito o Sarau a exposiçăo dos poemas no mural.

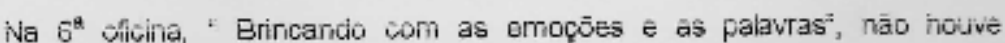
dificuldade para desenvower as atividades, pois eu já havia trabalhado o texto indicado no intcis do ane.

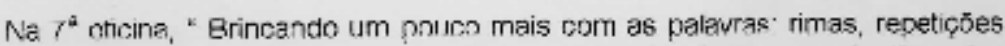
e alteraçöes", os alunce tweram difculdade parz entender o que s alteraçấ.

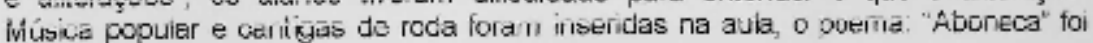
mimeografado e trabalhado e mais poemas form lidos c ouvidos.

Na $\hat{\sigma}^{\prime}$ añicina, "Conhecerıc poesia popular", cs aiuncs puderam conhecer lwros de corcel. o reoente e produçons através de inctótico foram feitas.

Na $9^{2}$ uicina "Vendo o muncio de um moxo poétice", aièm das sugestōes. trabalhei os poemas enrontrados nos ivroe didsticos, que sào trabalhadns durante o anc 
Na $10^{\text {a }}$ otrina "Analisando diferentes olhares sobre o mesmo tema" os poemae forem lidcs e ifıstrados, de acoido com o entendimento dos elunos.

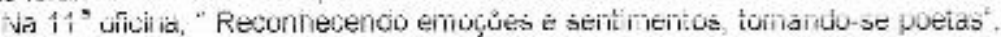
os alunos puideram perceber que: na poesia não se fala somente de amor. esim de toco tpo de sentiments. Procugces foram feitas, ilustradas e expostas nc mural

Na 12" oficins, "Teoendo poemas", o lugar onde os alunos vivem, foi representado coletivamente, ET, earolnas onde desenharam os principais pontos

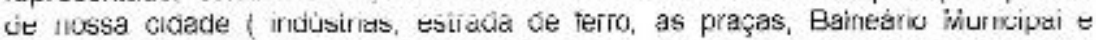
outros bairros rurais ) com isso passaram a escrever os seus poemls

$\mathrm{Na} 13^{2}$ oficina " Lanco o roque inal aos poemas", foi ieirc a revisan e as methores produczoes foram selecionaclas para que a Comissäco Julgadora decidisse

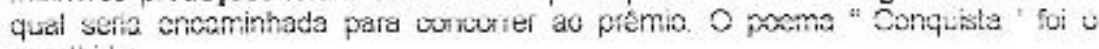
escoinido. 
ANEXO 3 - Proposta "A Infância em redondilhas" 
A Infância em redondilhas

Obs. Não há limites de linhas para responder cada uma das questões. Utilize o máximo de recursos para poder criar seu poema nas próximas aulas.

$1^{\mathrm{a}}$ aula

1. Leia o poema de Casemiro de Abreu.

2. Qual a imagem que o poeta apresenta da infância?

3. Coincide com a imagem que a estética do Romantismo apresentava sobre a infância?

4. Qual a imagem que você tem da infância? As imagens coincidem? Quais são as semelhanças? (Caso existam) e Quais são as diferenças? (caso existam)

5. Para escrevermos um poema sobre memórias da infância, vamos começar com alguns elementos dessa memória. Faça uma lista de coisas da infância de que você se lembra. Esses elementos podem ser divididos por categorias: cognitivas, sensoriais, emotivas...

2 a aula

6. Vamos conversar com a classe e ver quais os elementos que todos colocaram. Nesse momento, você pode fazer a escolha por quais "memórias" você colocará no poema. Lembrem-se de Pessoa, a emoção pode ser a alheia que você faz sua, ou a que vem do outro para de novo ser sua no texto.

7. Há muitos tipos de texto que podem ser utilizados no seu poema. Há tipos de texto: narrativo, descritivo, dissertativo etc. Para cada um deles, você deve escolher palavras concretas ou abstratas; verbos no tempo presente ou pretérito passado do indicativo; etc.

8. Para escrever um poema, essas palavras devem ser escolhidas pela relação que mantém entre si. Como será seu poema? Melancólico? Alegre? Cheio da peraltice de criança? Saudoso? Para cada um dessas avaliações do passado, você precisa decidir quais são as palavras mais adequadas.

9. Depois de ter escolhido as palavras pela família lexical ou pelo campo semântico, vamos às figuras sonoras. Aproveitando o tom que você escolheu para o poema, escolha agora as palavras que tragam essa sonoridade para seu texto. Podem ser aliterações, assonâncias, rimas internas e externas...

10. O poema que vocês vão escrever não é livre. Deve ter em sua estrutura duas estrofes ou mais, compostas por versos de sete sílabas, redondilha maior ou por versos de cinco sílabas, redondilha menor. O tom do poema é confessional, capaz de recuperar essa memória positiva ou negativa com a diç̧ão dos poemas populares, por isso o uso dessa métrica.

11. Vamos começar?

Cada uma dessas perguntas corresponde a um momento de duas aulas que teremos a partir desta semana.

Venham preparados para que a poesia tome conta de vocês! 


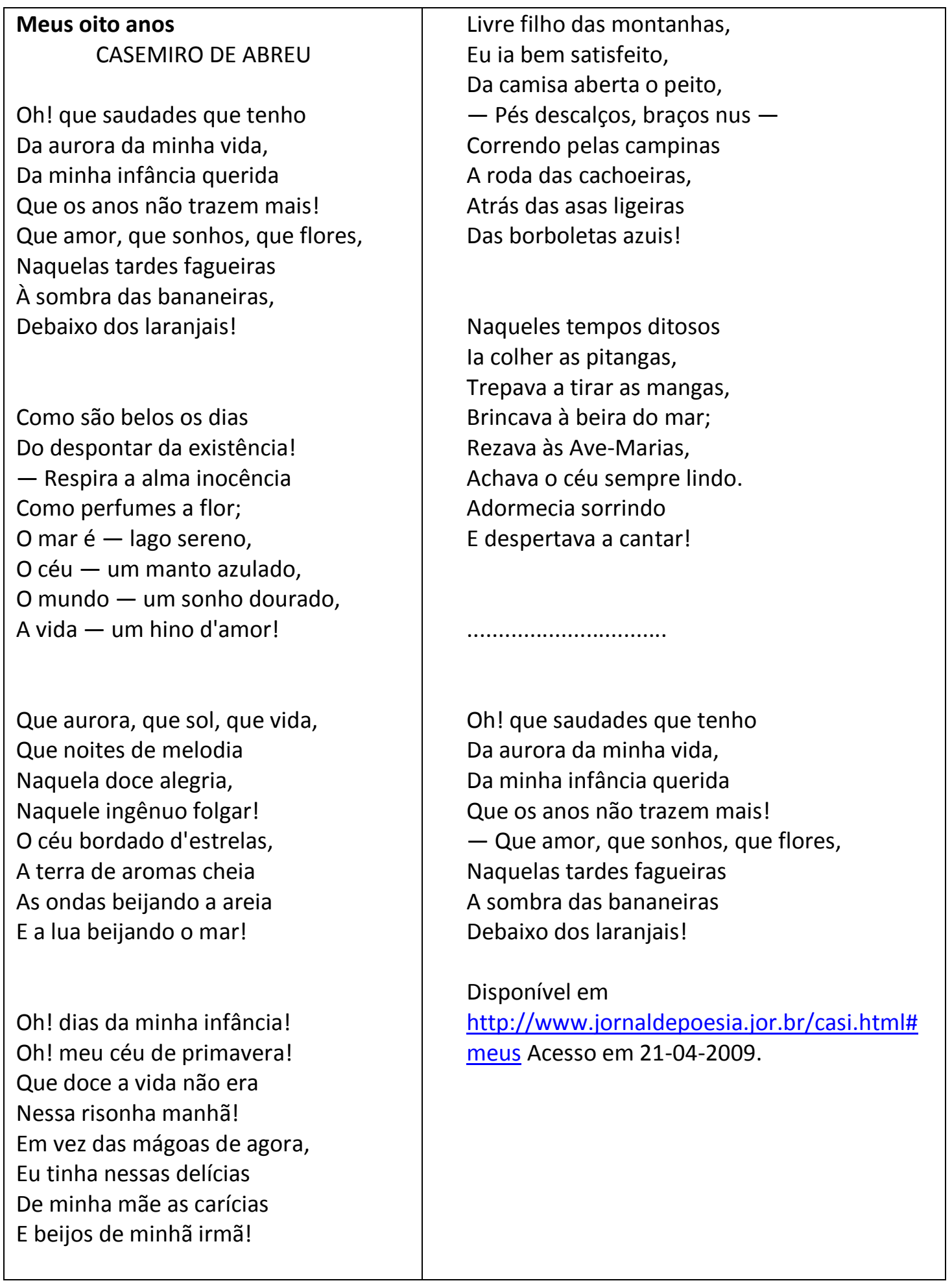

